\title{
Bay of
}

Pathways and

Consequences of

Legal Irregularity

Senegalese Migrants in France, Italy and Spain 


\section{IMISCOE Research Series}


This series is the official book series of IMISCOE, the largest network of excellence on migration and diversity in the world. It comprises publications which present empirical and theoretical research on different aspects of international migration. The authors are all specialists, and the publications a rich source of information for researchers and others involved in international migration studies.

The series is published under the editorial supervision of the IMISCOE Editorial Committee which includes leading scholars from all over Europe. The series, which contains more than eighty titles already, is internationally peer reviewed which ensures that the book published in this series continue to present excellent academic standards and scholarly quality. Most of the books are available open access.

For information on how to submit a book proposal, please visit: http://www. imiscoe.org/publications/how-to-submit-a-book-proposal.

More information about this series at http://www.springer.com/series/13502 
Erik R. Vickstrom

\section{Pathways and Consequences of Legal Irregularity}

Senegalese Migrants in France, Italy and Spain

黛 Springer Open 
Erik R. Vickstrom

IZA-Institute for Labour Economics

Bonn, Germany

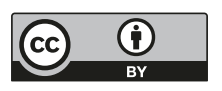

ISSN 2364-4087

IMISCOE Research Series

ISBN 978-3-030-12087-0

ISSN 2364-4095 (electronic)

https://doi.org/10.1007/978-3-030-12088-7

ISBN 978-3-030-12088-7 (eBook)

Library of Congress Control Number: 2019932978

(C) The Editor(s) (if applicable) and The Author(s) 2019, corrected publication 2019. This book is published open access.

Open Access This book is licensed under the terms of the Creative Commons Attribution 4.0 International License (http://creativecommons.org/licenses/by/4.0/), which permits use, sharing, adaptation, distribution and reproduction in any medium or format, as long as you give appropriate credit to the original author(s) and the source, provide a link to the Creative Commons licence and indicate if changes were made.

The images or other third party material in this book are included in the book's Creative Commons licence, unless indicated otherwise in a credit line to the material. If material is not included in the book's Creative Commons licence and your intended use is not permitted by statutory regulation or exceeds the permitted use, you will need to obtain permission directly from the copyright holder.

The use of general descriptive names, registered names, trademarks, service marks, etc. in this publication does not imply, even in the absence of a specific statement, that such names are exempt from the relevant protective laws and regulations and therefore free for general use.

The publisher, the authors, and the editors are safe to assume that the advice and information in this book are believed to be true and accurate at the date of publication. Neither the publisher nor the authors or the editors give a warranty, express or implied, with respect to the material contained herein or for any errors or omissions that may have been made. The publisher remains neutral with regard to jurisdictional claims in published maps and institutional affiliations.

This Springer imprint is published by the registered company Springer Nature Switzerland AG. The registered company address is: Gewerbestrasse 11, 6330 Cham, Switzerland 


\section{Preface}

Irregular migration has become a politically controversial issue in most immigrantreceiving countries. Academic research has shown that states and their immigration policies actively create the legal conditions for the existence and perpetuation of irregular migration. Much of this literature, however, focuses on the United States and thus cannot examine how variation in contexts of reception may produce different configurations of legal status. In addition, much research on immigration has neglected migration from sub-Saharan Africa despite this region's demonstrated migration potential.

This book uses a novel quantitative data source, the Migration Between Africa and Europe (MAFE) study, to examine the production of irregular legal status among Senegalese migrants in France, Italy, and Spain and the consequences of configurations of irregularity. A historical chapter outlines the evolution of immigration policies in each country that set the parameters for irregular legal status.

The first empirical chapter studies the pathways into irregular status for Senegalese migrants. Pathways early in a migrant's trip-no-visa entry and overstaying-are more sensitive to both contextual variables and access to forms of capital, indicating that both state control and migrant agency shape these pathways. In contrast, befallen irregularity is less related to contextual variation, perhaps because immigration policies and enforcement resources are not focused on migrant integration.

The second empirical chapter examines how immigration policy creates gendered channels of access to labor markets. Senegalese women with configurations of legal status indicative of family reunification are more likely than women with other legal statuses to be economically inactive upon arrival, while there is little association between Senegalese men's legal status and their participation. Results show, however, that family reunification does not preclude labor-market participation, as women with family-reunification profiles eventually transition into economic activity. 
The third empirical chapter looks at the link between legal status and transnational activities. It finds that Senegalese migrants with irregular status are effectively confined to the destination territory, making them unable to visit the homeland. This confinement short-circuits the entire social infrastructure underlying remitting and investing: the affective ties that underlie long-distance cross-border activities wither when migrants are unable to circulate. 


\section{Acknowledgements}

This book would not have been possible without the support of many institutions and individuals. The dissertation on which this book is based greatly benefited from the guidance of the world-class scholars who advised it. Alejandro Portes provided expert training in the art and craft of sociological research, and I am grateful for both his support and his persistence in pushing me to improve the quality of my work. Doug Massey was inspirational in his approach to the study of international migration, and also provided unflagging support as an advisor. I owe a special debt of gratitude to Cris Beauchemin, who welcomed me into the scientific communities of the Migration between Africa and Europe (MAFE) project and the Institut national d'études démographiques (INED). In addition to his valuable and detailed intellectual guidance, his balanced approach to life and his firm moral support were indispensable resources for me as I worked on the project. He has been a true mentor.

I owe a debt of gratitude to my colleagues at Princeton University, INED, the MAFE project, the U.S. Census Bureau, and the OECD for their guidance and support in the completion of this book. My work would have been impossible without the dedication and efforts of support staff at Princeton University in the Department of Sociology, the Office of Population Research, the Joint Degree Program, and Stokes Library. I am also grateful to support staff at INED.

The IMISCOE Research Network was instrumental in shepherding this book to publication. I am grateful to IMISCOE for the 2015 Maria Baganha Dissertation Award, which provided the opportunity to publish my dissertation. Anna Triandafyllidou and Irina Isaakyan of the IMISCOE Book Series editorial team provided exceptional support in the publication process. The detailed and incisive comments of an anonymous reviewer greatly improved the finished manuscript.

I am grateful for funding for fellowships, research, and travel from Princeton University (the Department of Sociology, the Office of Population Research, the Joint Degree Program, the Princeton Dean's Fund for Scholarly Travel, and the Princeton Institute for International and Regional Studies) and the Institut national 
d'études démographiques (INED). This research was supported by the Eunice Kennedy Shriver National Institute of Child Health and Human Development (grant \#5R24HD047879) and the National Institutes of Health (grant \#5T32HD007163).

Above all, I am grateful for the love and support of my friends and family. 


\section{Contents}

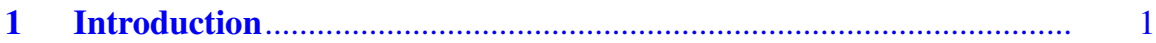

$1.1 \quad$ What Is Irregularity? ................................................................ 2

1.2 Multiple Contexts of Reception, Complex Configurations of Legal Status, and the Consequences of Irregularity................... 3

1.3 Variation in Legal Contexts of Reception Is Crucial for Understanding the Pathways into and Consequences of Irregularity ........................................................................... 4

1.4 Simplified Operationalizations of Legal Status Hamper Understanding of Irregularity

1.5 So What? When, How, and Why Does Irregularity Matter? .......... 7

1.6 Senegal as a Strategic Site for Migration Research ....................... $\quad 10$

1.7 The Migration Between Africa and Europe (MAFE) Project........ 13

1.7.1 Sampling Design of the MAFE Project ............................ 14

1.7.2 MAFE Questionnaires .................................................... 16

1.7.3 Advantages of the MAFE Data........................................... 17

1.7.4 Limitations of the MAFE Data ......................................... 20

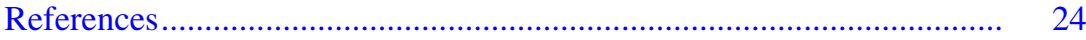

2 Evolution of Immigration-Control Policies in France, Italy,

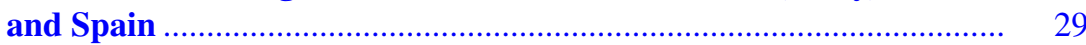

2.1 Policy Evolution in Multiple Contexts of Reception ..................... 29

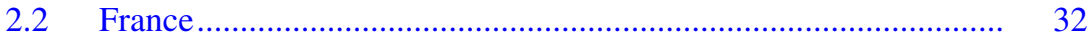

2.2.1 Colonial "Assimilation" and Citizenship ......................... 32

2.2.2 Link Between Colonial-Era Policies and Migration........ 33

2.2.3 Post-War Reconstruction and the Importation of Foreign Labor ....................................................... 34

2.2.4 The 1960s: The Special Regime of the Bilateral Accord and Widespread Irregularity ................................. 40

2.2.5 The 1970s: The "Closing" of the French Border and the Erosion of the Bilateral Accord. 
2.2.6 The 1980s: Immigration Policy as a Political Football and Consensus in Border Security .....

2.2.7 Visa Requirements for Senegalese and the Re-negotiated Bilateral Accord of 1995

2.2.8 The 1990s: Pasqua, Debré, and the Sans-Papiers Movement

2.2.9 The 2000s: Selective Immigration and Coordinated Migration Management

2.3 Senegalese Migration to New Destinations

in Southern Europe.

2.4 Italy

2.4.1 Pre-1986: Italian Emigration and the Fragmentation of Immigration Policy....

2.4.2 1986-1998: National-Level Immigration Policy and "Moral Panic"

2.4.3 The 2000s: "Strong Restrictive Ambition".................... 61

$2.5 \quad$ Spain.................................................................................. 62

2.5.1 1970s-1999: European Integration............................... 62

2.5.2 2000-2008: Rights and Freedoms of Foreigners, Alien Affairs, and Plan África.................................... 66

2.6 Conclusion................................................................................ 69

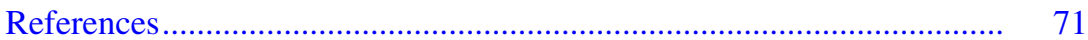

3 Pathways into Irregular Legal Status of Senegalese Migrants

France, Italy, and Spain.

3.1 Conceptual Approaches to Irregularity ....................................... 76

3.1.1 The Legal and Social Production of Irregularity ........... 78

3.1.2 Multidimensionality of Irregularity .............................. 81

3.1.3 Incomplete State Control and Migrant Agency ............. 82

3.1.4 Pathways into Irregularity............................................. 83

$3.2 \quad$ Hypotheses ...................................................................... 86

3.3 Data and Methods ................................................................. 87

3.3.1 Sample .......................................................... 87

3.3.2 Legal Status Variables ................................................. 88

3.3.3 Predictor Variables ...................................................... 92

3.3.4 Models ...................................................................... 92

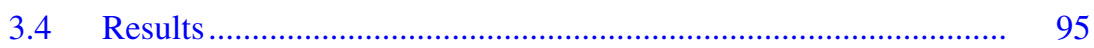

3.4.1 No-Visa Entry .......................................................... 95

3.4.2 Pathway: Overstaying ................................................ 99

3.4.3 Pathway: Befallen Irregularity ................................... 102

3.5 Discussion ...................................................................... 104

3.6 Conclusion......................................................................... 107

Appendix: Raw Coefficient Estimates for Models of Pathways into

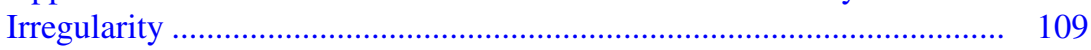

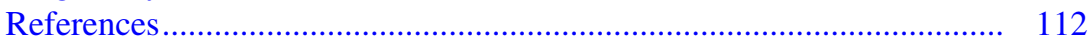


4 Legal Status, Gender, and Economic Incorporation of Senegalese Migrants in France, Italy, and Spain .

4.1 Gendered Channels of Migration: Family Reunification,

Legal Status, and Dependency

4.1.1 Reunification and Gendered Economic and Administrative Dependency

4.1.2 Family Reunification Regimes and Configurations of Legal Status

4.2 Reunified Women and the Labor Market ..................................... 119

4.3 Limitations of Existing Research ............................................. 120

4.3.1 Assuming Participation: Undocumented Status and Wages in the US .

4.3.2 Ethnic Penalties on Employment in Europe, but Limited Measures of Legal Status

4.4 Gender Norms, Family Reunification, and Work Among Senegalese Migrants.

4.5 Hypotheses ....................................................................... 126

4.6 Data and Methods .................................................................... 127

4.6.1 The Analytic Sample................................................... 127

4.6.2 Outcome Variables ....................................................... 128

4.6.3 Predictor Variables ...................................................... 131

4.6.4 Models .......................................................................... 133

$4.7 \quad$ Results ............................................................................. 134

4.7.1 Gender, Partner Location, and Legal Status .................. 134

4.7.2 First-Year Economic Activity ...................................... 136

4.7.3 Transitions out of Employment for Men ....................... 144

4.7.4 Transitions into Employment for Women....................... 144

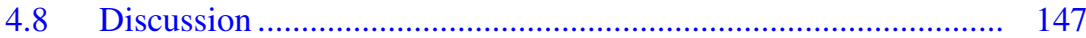

4.9 Conclusion............................................................................ 149

Appendix: Raw Coefficient Estimates for Models in this Chapter.......... 151

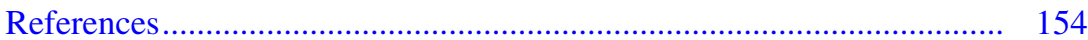

5 Legal Status, Territorial Confinement, and Transnational

Activities of Senegalese Migrants in France, Italy, and Spain .......... 157

5.1 Types of Transnational Activities ............................................... 158

5.2 The Role of the State in Migrant Transnational Activities........... 159

5.3 Homeland Visits and Territorial Confinement of Migrants with Irregular Status ............................................................... 161

5.4 Blocked Transnationalism and Structural Exclusion ................... 162

5.5 Affective Ties, Homeland Visits, and Non-mobile Transnational Activities........................................................... 163

5.6 Caging Non-mobile Transnational Activities .............................. 165

5.7 Transnational Activities of Senegalese Migrants ........................ 166

5.8 Hypotheses ...................................................................... 168 


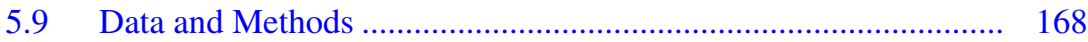

5.9.1 Data Source ................................................................. 168

5.9.2 The Analytic Sample........................................................ 169

5.9.3 Outcome Variables ........................................................... 169

5.9.4 Predictor Variables ............................................................ 170

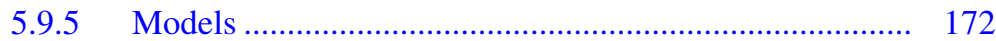

5.9.6 Estimating Indirect Effects in a Non-linear

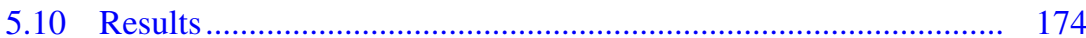

5.10.1 Descriptive Results ........................................................ 174

5.10.2 Multivariate Results ..................................................... 177

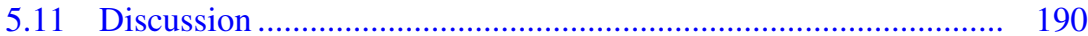

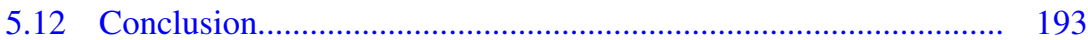

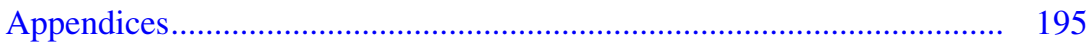

Appendix A: Wording of Questions on Transnational Activities in MAFE-Senegal Questionnaire ........................................................ 195

Appendix B: Raw Coefficient Estimates for Models from

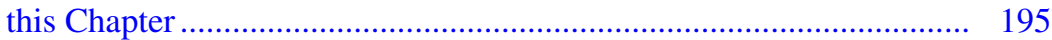

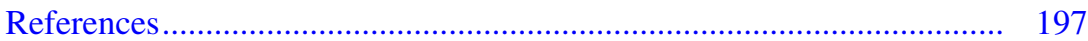

6 Conclusion ....................................................................... 201

6.1 Evolution of Immigration-Control Policies in France, Italy,

6.2 Pathways into Irregular Legal Status............................................. 203

6.3 Legal Status, Gender, and Labor Market Incorporation................. 204

6.4 Legal Status and Transnational Activities .................................... 205

6.5 What Is Irregularity and Why Does It Matter?............................. 207

6.6 Implications for Policy ............................................................ 209

6.6.1 The Unintended Consequences of Immigration

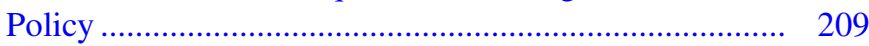

6.6.2 Co-development, Veiled Restriction, and the African "Capacity Crisis" .............................................. 211

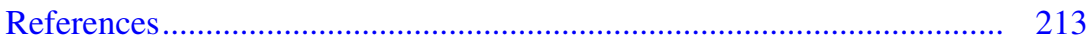

Correction to: Pathways and Consequences of Legal Irregularity ............ C 1 


\section{List of Figures}

Fig. 1.1 Geographic position of Senegal in relationship to West Africa and Western Europe

Fig. 1.2 MAFE-Senegal biographical questionnaire module on legal statuses

Fig. 2.1 Senegalese migrant stocks in France, Italy, and Spain (country of birth). Reproduced from Mezger Kveder (2012).....

Fig. 3.1 Temporal and categorical complexity of irregularity of legal status

Fig. 3.2 Entry status by destination and period

Fig. 3.3 Predictive margins of no-visa entry, by destination and period, with $95 \%$ confidence intervals

Fig. 3.4 First legal status by destination and entry status

Fig. 3.5 Predictive margins of NRP_NWP first status, by entry status and destination, with $95 \%$ confidence intervals.....

Fig. 3.6 Average marginal effect of entry with visa on NRP_NWP first status, with $95 \%$ confidence intervals.................................. 102

Fig. 3.7 Legal status transitions .......................................................... 103

Fig. 3.8 Predictive margins of transition to NRP_NWP, by prior status, with $95 \%$ confidence intervals

Fig. 4.1 Legal status at arrival by gender, destination, and location of spouse.

Fig. 4.2 Legal status among Senegalese women during year of arrival, by destination, partner location, and migration motivation

Fig. 4.3 First-year activity status by legal status and country of residence, Senegalese men.

Fig. 4.4 First-year activity status by legal status and country of residence, Senegalese women.

Fig. 5.1 Hypothesized relationships between irregular legal status and transnational activities 
Fig. 5.2 Average level of transnational activities, by legal status, with $95 \%$ confidence intervals

Fig. 5.3 Average level of transnational activities, by short return and legal status, with $95 \%$ confidence intervals.

Fig. 5.4 Predicted probability of short return, by legal status category, with $95 \%$ confidence intervals (Dashed line represents grand mean of short returns)

Fig. 5.5 Predicted probability of remitting by legal status category, with $95 \%$ confidence intervals (Dashed line represents grand mean of remitting)

Fig. 5.6 Predicted probability of investing by legal status category, with $95 \%$ confidence intervals (Dashed line represents grand mean of investing)

Fig. 5.7 Predicted probability of HTA participation by legal status category (Dashed line represents grand mean of HTA participation)

Fig. 5.8 Average marginal effects of short returns, by outcome, with $95 \%$ confidence intervals 


\section{List of Tables}

Table 1.1 Percentage of Senegalese migrants without a residence permit at selected time points, MAFE-Senegal .....

Table 2.1 Terms for visa, residence permit, and work permit in France, Italy, and Spain

Table 2.2 Synthesis of major immigration measures in France and consequences for migrant irregularity

Table 2.3 Synthesis of major immigration measures in Italy and consequences for migrant irregularity....

Table 2.4 Synthesis of major immigration measures in Spain and consequences for migrant irregularity.

Table 3.1 Legal parameters of irregularity for Senegalese migrants in France, Italy, and Spain, 1960-2008

Table 3.2 Descriptive statistics for MAFE-Senegal sample

Table 3.3 Legal-status variables and coding, MAFE-Senegal survey

Table 3.4 Average marginal effects of models for no-visa entry, overstaying, and befallen irregularity

Table 4.1 Typology of female migrant types by legal status and country

Table 4.2 Descriptive statistics

Table 4.3 Multinomial logistic regression of first-year activity status by gender, average marginal effects.

Table 4.4 Average marginal effects of legal status on first-year activity status, by country of residence and gender

Table 4.5 Discrete-time survival analysis of transitions into and out of employment by gender, average marginal effects

Table 4.6 Average marginal effects of legal status on risk of employment for women, by country of residence 
Table 5.1 Descriptive statistics for MAFE-Senegal sample,

by legal status

Table 5.2 Multivariate results for random-intercept regression models of transnational activities

Table 5.3 KHB decomposition of effects of legal status categories on non-mobile transnational activities via short returns

The original version of this book was revised. The Acknowledgement was not included which is now inserted. In addition to the above, Chapters 3, 4 and 5 have been updated with the footnotes which were initially not included. A correction to these chapters can be found at https://doi.org/ 10.1007/978-3-030-12088-7_7 


\section{Chapter 1 \\ Introduction}

Immigration and its economic, political, cultural, and social consequences have recently emerged as increasingly contentious issues in Europe. Although some European countries have long histories of welcoming immigrants, the relative cultural and ethnic homogeneity of many others has thrown recent increases in foreignborn populations into sharp relief. European anxiety over immigrant integration has also increased with the recognition that unauthorized immigration has been a persistent and seemingly intractable challenge for the continent's immigration policies. While quantifying irregular migration in Europe remains an exercise in "counting the uncountable" (Vogel et al. 2011), recent research estimated the EU's stock of irregular migrants to be between two and four million ${ }^{1}$ (Triandafyllidou 2009; Vogel et al. 2011).

These stocks of irregular migrants have given rise to reactive migrationmanagement policies: between 1973 and 2008, European countries carried out 68 regularization programs, thereby adjusting the status of 4.3 million people (Kraler 2009). The majority (59\%) of these regularization programs occurred between 1998 and 2008 (Kraler 2009). Although many European countries-both post-war labor importers (such as France) and more recent countries of immigration in Southern Europe (such as Italy and Spain)—have employed toleration of unauthorized residence and subsequent regularization of status as a de facto migration policy to meet the structural demand for immigrant labor (Kraler 2009), the frequency and visibility of regularizations have contributed to public and political perceptions of irregular immigration as a major issue.

\footnotetext{
${ }^{1}$ Given the impact of the refugee crisis, the estimates of irregular migrants in the EU are likely quite different today yet the close interaction between asylum and undocumented migration makes it very difficult to conceptually unpack asylum from irregular migration. In practical terms, significant numbers of irregular entrants enter the asylum system and temporarily obtain a (limited) status as asylum seekers, those who are rejected often are known to the authorities and are in a strict sense not undocumented, even if liable to return. Nonetheless, there have been few asylum seekers from Senegal either historically or during the recent European refugee crisis.
} 
Irregular migration from sub-Saharan Africa in particular has provoked fears of an "invasion" of "fortress Europe" (Collier 2013; Connor 2018; de Haas 2008b). Despite this concern, irregular migration in Europe in general and irregularity among African migrants in particular are poorly understood phenomena. Although a voluminous research literature on undocumented migration exists in sociology, economics, and political science, many studies are limited by reliance on limited variation in contexts of reception and a simplified conceptualization of legal status (Bean et al. 1990; Espenshade 1995; Massey and Bartley 2006; Massey and Capoferro 2004; Massey and Singer 1995; Portes 1978, 1979). Most studies of African undocumented migration to Europe are either small-scale or speculative, leading researchers to call for more rigorous examination of this phenomenon (de Haas 2008a; Lessault and Beauchemin 2009a; Vickstrom 2014; Beauchemin and Lamboni 2017; Schoumaker et al. 2018).

This book will examine how immigration policies in Europe create irregularity among Senegalese migrants and how the resulting complex trajectories of legal statuses shape these migrants' lives. While this research will investigate an understudied but increasingly important emigrant population (Hatton and Williamson 2003), its relevance is not limited to understanding African migration. The findings help inform policy debates surrounding this phenomenon in Europe and contribute to refining sociological theories of irregular migration.

\subsection{What Is Irregularity?}

"Irregular" is often used interchangeably with "undocumented," "unauthorized," "clandestine," or "illegal" to describe both an aggregate process of migration and an individual attribute of migrants (Donato and Armenta 2011). While the terms seem to describe similar phenomena, migration scholars argue that different terms have different underlying historical specificities and political resonances (Düvell 2008). Scholars increasingly avoid the terms "illegal migration" and "illegal migrant" because of their implicit criminalization of migrants; "illegal" is often used as a technical term to describe entering a country in violation of the law or as a description of a condition (e.g., "illegal work") (Triandafyllidou 2010). "Unauthorized" is often used in the U.S. context (Düvell 2008), but does not necessarily adequately describe the situation of the foreign-born population in a given destination as not all foreigners need explicit authorization to enter, reside, or work in a destination country (Triandafyllidou 2010). "Undocumented" is also limited in its descriptive capacities by the fact that not all migrants who enter, reside, or work without legal permission actually lack documents. "Irregular" is often used in the European context and has broad connotations that can refer to both flows and stocks of migrants and can encompass a variety of legal arrangements (Triandafyllidou 2010). This book thus uses the term "irregular" to describe statuses that arise from migration that occurs outside of the legally defined framework for entry, residence, or work of 
foreigners in a destination country, and, by extension, migrants that have engaged in such entry, residence, or work. ${ }^{2}$

\subsection{Multiple Contexts of Reception, Complex Configurations of Legal Status, and the Consequences of Irregularity}

Advancing our understanding of irregular migration in Europe as well as in other settings depends on challenging the limitations of existing research paradigms: existing theories built on limited variation in contexts of reception and a simplified conceptualization of irregularity cannot satisfactorily explain irregular migration and its consequences in Europe. This book will fill these gaps by asking how multiple contexts of reception produce distinct pathways into irregular legal statuses and how the resulting complex configurations of irregular statuses shape migrants' economic integration into host societies as well as their ongoing participation in the development of their homelands. While this research is vital for understanding irregular migration in Europe, it will also help open new theoretical perspectives valuable for future research on irregular migration in other contexts, including the United States. This book will combine a review of historical immigration-policy texts with analyses of a unique quantitative dataset on Senegalese migrants in Europe to answer these questions. African migration in general and Senegalese migration in particular offer unique opportunities to study the production and consequence of pathways into irregular legal status because of diversity in contexts of reception and exit.

This book is organized into three parts. The first part examines the framework of immigration policy and mechanisms of control across multiple contexts of reception to understand the legal creation of pathways into different kinds of irregular statuses among Senegalese migrants in France, Italy, and Spain. In doing so, it will attempt to understand the variation in policies both within each context over time and across these contexts. The second part is an empirical analysis that will attempt to incorporate insights about the variation of policies developed in the first part and apply them to a conceptual framework that is able to make sense of multiple pathways into irregular status. The third part of the book grapples with the consequences of complex configurations of irregular status for Senegalese migrants. The analyses

\footnotetext{
${ }^{2}$ In this book, I use "legal status" to refer to the status that migrants possess vis-à-vis the legal framework that governs their entry, residence, or work in a given country. "Fully regular status" (or "fully regular legal status") denotes possession of all required authorizations to live and work in a given country, while "fully irregular status" (or "fully irregular legal status") denotes the lack of all required authorizations to live and work in a country. This contrasts with other academic work where "legal status" can refer to what this book calls "fully regular status." Thus, "legal" here simply refers to the domain of the status and does not indicate the possession of authorization. An analog would be the term "socioeconomic status," which describes a person's status in the socioeconomic realm; additional qualifiers (such as "high" or "low") would be required to describe an individual's status.
} 
will seek to explore "...when and if-and to the degree to which-the legal reality constrains the relationships and actions" (Cvajner and Sciortino 2010: 397) of migrants with configurations of irregular status.

\subsection{Variation in Legal Contexts of Reception Is Crucial for Understanding the Pathways into and Consequences of Irregularity}

The first part of the book explores the variation in the legal contexts of reception facing Senegalese migrants over time in France, Italy, and Spain. The legal constraints that migrants face in terms of entry, working, and residing in their chosen destination are an important part of what sociologists call the "context of reception." Alongside the conditions of the labor market and the characteristics of the immigrant's ethnic community, Portes and Rumbaut (2006) define the policies of the receiving government the most important aspects of any given context of reception and argue that these contexts can channel immigrants with similar individual endowments into different paths in the destination society.

Portes and Böröcz (1989) consider three ideal-typical illustrations of contexts of reception that different groups of migrants may face. A negative context of reception features low receptivity on the part of the destination society such as governmental attempts to reduce or prohibit inflows, employer discrimination in hiring for only menial jobs, and general societal prejudice. These negative stances lead to precarious settlement, blocked economic mobility, and an imperiled second generation (Portes and Rumbaut 2001, 2006). A neutral context of reception permits but does not encourage immigration and does not stereotype immigrants; migrants adapt to this neutral context through individualistic models of occupational and economic attainment. An advantaged context of reception features active legal and material assistance from governments and a positive public perception; migrants are often able to combine this governmental support with pre-existing skills to adapt favorably to the destination society. These contexts of reception combine with the class origins of immigrants to create the diversity of settlement patterns or modes of incorporation apparent for contemporary immigrants (Portes and Böröcz 1989). Contexts of reception are thus crucial for understanding immigrant incorporation.

While the legal, economic, and social elements of these contexts are interrelated, Portes and Böröcz (1989) point out that it can be useful to separate them for analytical purposes. Governmental and policy stances towards immigrants are of particular importance for two reasons. First, immigration policies create and police the legal categories to which migrants are subject in their entry, settlement, and work in destination countries. Legal contexts of reception thus produce pathways into a variety of regular, semi-compliant, and irregular legal statuses (De Genova 2002, 2005). Second, irregularity of legal status resulting from an exclusionary stance from the 
legal context of reception may result in negative consequences for multiple aspects of immigrants' lives.

While research in Europe and the U.S. provides important evidence that contexts of reception, and the legal statuses they define, matter for immigrant integration into host societies, much of the research is limited by reliance on limited variation in contexts of reception. This is clearly the case with research done in the U.S. context. U.S.-focused research has argued that variation in context of reception can help explain resilient differences in integration outcomes among different migrant national-origin groups; but the group-specific contexts are all nested in one national political and socioeconomic context. Similarly, variations in policies-such as the amnesty resulting from the 1986 Immigration Reform and Control Act - are within an overall U.S. context that has a long history of engagement with immigration. Existing research has not sought to understand how cross-national variations in policies, labor markets, and communities can shape the production and consequences of migrant irregularity. In effect, much existing research has sought to generalize from the U.S. case by using comparisons between multiple immigrant groups. While the contexts of reception facing these groups vary within the overall American context, additional insight could be gained by comparing multiple destinations.

Research in Europe is more varied in its engagement with multiple legal contexts of reception faced by migrants across a multitude national political and socioeconomic settings, many studies nonetheless remain limited to case studies of unitary contexts and do not engage in comparison across contexts. Two subsets of research in the European context highlight this reliance on unitary contexts of reception. The first subset focuses on single groups in single countries, such as Turks in Germany (Gerdes and Reisenauer 2012), Senegalese in Italy (Riccio 2001), or Ghanaians in the UK (Krause 2008) or the Netherlands (Mazzucato 2008). The second subset includes studies of one or more migrant groups in a single context of reception. Diehl and Schnell (2006) study labor migrants in Germany, with a focus on Turks and emigrants from the former Yugoslavia. Bradatan and Sandu (2012) focus on Spain and compare Moroccans and Romanians. Riccio (2008) examines the experiences of Ghanaians and Senegalese in Italy. While all of these studies contribute valuable findings about single contexts of reception, they cannot help us understand how variation across contexts may shape migrants' experiences.

Theoretical insights derived from studies based on a unitary context of reception cannot readily explain migrant irregularity in a European setting marked by a diversity of contexts of reception. Fortunately, the European context also provides examples of comparative studies that leverage multiple contexts of reception. Ersanilli and Koopmans $(2010,2011)$ compare Turkish immigrants in the Netherlands France, and Germany, while Østergaard-Nielsen (2003) studies Turkish political organizations in the Netherlands, Germany, and Denmark. Fokkema and de Haas (2015) compare multiple groups of African migrants in Italy and Spain. The Undocumented Workers' Transitions Project (McKay et al. 2011) examined irregularity across seven countries (Austria, Belgium, Denmark, Italy, Spain, UK and 
Bulgaria). Van Meeteren (2012) includes both the Netherlands and Belgium in analyses of irregular migration, and van Nieuwenhuyze (2008) compares Senegambians in Barcelona and Antwerp.

This book will draw inspiration from these comparative approaches by taking advantage of variation across multiple legal contexts of reception. Chapter 2 traces the evolution of immigration policies and the external and internal mechanisms of control that they define (Brochmann 1999) in the main Senegalese European destination countries of France, Italy, and Spain. The chapter examines immigration laws and other legal texts (such as treaties, decrees, and administrative circulars) to outline how these states created the legal parameters that defined pathways (Düvell 2011b) to regular or irregular legal statuses for Senegalese migrants. Variations in contexts of reception have produced a variety of socio-legal configurations that have given rise to different pathways of irregularity. Senegalese in France had de facto regular status for much of the 1960s and 1970s in that they did not need explicit authorization to enter or reside in France and were able to take advantage of common post facto regularization procedures. Irregularity became more common among Senegalese in France as this preferential regime crumbled. Irregularity seems to have been a consistent component in contexts of reception in Italy and Spain, as their frequent and massive regularization programs demonstrate. Much of this irregularity seems to stem from the mismatch between restrictive immigration-control measures and structural demands for cheap, low-skilled labor.

\subsection{Simplified Operationalizations of Legal Status Hamper Understanding of Irregularity}

The second part of the book applies the lessons learned from the first part about variation across legal contexts of reception to an empirical analysis of pathways into multiple configurations of irregular status for Senegalese migrants in Europe. In so doing, it draws on insights into the multidimensionality of legal statuses, especially in the European context. Much research on irregular migration is limited by a simplified conceptualization of legal status. Many studies, especially in the U.S. context, employ a simple dichotomization of legal status, comparing undocumented to documented migrants (or newly legalized migrants to legal migrants—see Borjas and Tienda 1993; Connor and Massey 2010). While this practice may have much to do with data limitations, scholars of immigration have also been calling for a more nuanced approach that is sensitive to transitions between multiple kinds of legal statuses (Massey and Capoferro 2004; Menjívar and Kanstroom 2014). The multitude of contexts of reception in Europe along with frequent recourse to regularization programs mean that migrants may experience multiple legal statuses simultaneously (e.g., legal residence without legal right to work) along with complex trajectories of legal status over time. A reliance on a documented/undocumented dichotomy may thus obscure both the factors producing various forms of 
irregularity and the consequences that complexities of legal status have for the lives of migrants.

Research on irregularity in Europe has been more sensitive to the nuances of multiple legal categories. Triandafyllidou (2010) argues that conceptualizations of irregularity depend on the legal domain under consideration (entry, residence, or work). This approach allows for differentiation between different kinds of irregular statuses (e.g. irregularity of entry, residence or work) and for transition between statuses over time. This research shows, in fact, that status-related flows-movement between regular and irregular status - is a more important pathway into irregularity than irregular geographic flows across borders (Triandafyllidou 2009, 2010). Some empirical analyses in the European context have operationalized legal status in a way that accounts for complexities of legal domains and transitions over time. Ruhs and Anderson (2010) highlight the condition of semi-compliance, in which migrants who are legally resident work in violation of restrictions on their employment.

Chapter 3 draws on the European literature on complex conceptualizations of legal status to examine how immigration policies and mechanisms of immigration control are translated into multiple pathways into irregular status. The chapter models three such pathways: entry without a visa, overstaying, and befallen irregularity. Using data from the Migration between Africa and Europe (MAFE) Project, the chapter empirically tests the hypotheses that variation in context of reception-as measured by destination and period-would produce different pathways, and that migrants' strategies, as measured by access to forms of capital and institutional connects, would also influence their navigation of these pathways. Analyses of the empirical data reveal that pathways that occur early in a migrant's trip-no-visa entry and overstaying - are more sensitive to both contextual variables and access to forms of capital, indicating that both state control and migrant agency shape these pathways. In contrast, befallen irregularity is less related to contextual variation, perhaps because immigration policies and enforcement resources are not focused on migrant integration. Furthermore, these transitions are rare and migrants who have "legal capital" in the form of regular status are able to avoid this transition.

\subsection{So What? When, How, and Why Does Irregularity Matter?}

The third part of the book looks at the consequences of configurations of legal status for the economic integration of Senegalese migrants in France, Italy, and Spain as well as their ongoing transnational participation in their homeland. In so doing, it both draws on large body of literature that demonstrates the negative effects of irregular status on various facets of migrants' lives and problematizes the relationship between irregularity and migrants' life chances. Some scholars have gone so far as to say that irregularity "forces immigrants into a wholly underground 
existence" (Portes and Rumbaut 2006: 93), but this book will attempt to ascertain when, how, and why irregularity matters for migrants.

A voluminous research literature in both Europe and the United States has found that negative legal contexts of reception can not only create irregularity of status among migrants but also puts migrants with irregular legal status and their children at an economic and social disadvantage compared to migrants with regular legal status (Alba and Nee 2003; Borjas and Tienda 1993; Kossoudji and Cobb-Clark 2000; Phillips and Massey 1999; Portes and Rumbaut 2001). Research on a multitude of migrant populations in Europe has shown the importance of the legal facets of the contexts of reception on migrant integration in an array of European countries. Cvajner and Sciortino (2010) theorize the link between precarious legal status and exclusion from formal institutions such as the labor market, and argue that irregularity forces migrants to rely on high-cost survival strategies to negotiate the risky environments, such as informal labor markets, to which they are relegated.

Many empirical studies of irregularity in Europe echo the theoretical link between lack of secure legal status and precarity. Anderson (2010) highlights how immigration-control mechanisms create precarity among immigrant workers in Europe through dependency on employers fear of deportation. Van Nieuwenhuyze's (2008) study of Senegambians in Barcelona and Antwerp shows that irregularity can force migrants into the shadow economy, where wages are low, working conditions bad, and there is little recourse against abusive employers. Sigona (2012) demonstrates how irregularity leads migrants in the United Kingdom to fear deportation and have difficulty establishing trust, fostering their social isolation. Results from the Undocumented Workers' Transitions Project show how migrants with irregular status regularly face discrimination, exploitation, and even violence (McKay et al. 2011). The European Union Agency for Fundamental Rights (2011) summarizes many of the negative effects of irregularity: it creates a risk of exploitation in the labor market, leads to precarious and insecure housing situations, and can imperil migrants' access to healthcare and education.

Research on immigration to the United States echoes many of the negative associations between irregularity and migrants' life chances demonstrated in the European context. Massey's (2007) research shows that the category of "undocumented migrant" has become a prime vehicle for inequality in the U.S. by excluding undocumented migrants from effective participation in labor markets and other formal institutions that structure life chances. Immigration policy and border control in the U.S. have created a social category of migrants devoid of regular legal status and the rights it affords. Massey and colleagues (2007; Durand et al. 2016) identify the immigration-control system as the principle institution of stratification for Latinos in general and for Mexicans in particular. Massey (2007) argues that wage discrimination and marginalization from the social safety net in the wake of the Immigration Reform and Control Act (IRCA) in the 1980s led to a decrease in income and an increase in poverty among Latinos. Other literature confirms that legal status has become an axis of stratification in the United States (Menjívar 2009). Psychological research using the stereotype content model has found that undocumented migrants are seen as "barely human" at a neural level, confirming their disadvantaged position 
in the American stratification system (Lee and Fiske 2006; Massey 2007). Greenman and Hall (2013) conclude that legal status is an important axis of stratification for Latinos' educational attainment, with undocumented youth less likely to graduate from high school and enroll in college. Marrow (2013) lists the myriad other ways in which immigrants' life chances are adversely affected by the institution of illegality: undocumented migrants suffer disparities in access to health care and education, they are unable to get drivers' licenses and are thus less geographically, economically, and socially mobile; in addition, spillover effects mean that many documented Latino immigrants are caught in the legal, social, and representational webs of illegality in ways that restrict their participation in American society.

Despite this mountain of evidence that irregular legal status is detrimental to migrants, the third part of this book will try to dig deeper to examine when, how, and why configurations of irregularity might matter. As Van Meeteren (2012) points out, policies and the configurations of irregularity that they produce do not necessarily mechanically constrain migrants' actions and it is important to try to understand migrants' reactions to the legal constraints they face. This approach echoes Cvajner and Sciortino's (2010) exhortation to pay attention to how and to what extent legal realities constrain the actions of migrants.

The empirical analyses in the third part of the book will thus examine how configurations of legal status constrain Senegalese migrants' labor-market participation and transnational activities. Chapter 4 focuses on how immigration policy creates gendered channels of access to destination societies' labor markets. The chapter hypothesizes that the effect of legal status on economic incorporation will differ for women and men. Women's legal statuses are more likely to be the product of dependency-inducing family reunification policies that disincentivize work, while men have more options for labor-market access regardless of legal status. Women's labor-market participation is thus structured by their legal status, with those women reunifying with spouses at a destination less likely to work upon arrival than autonomous women or men. At the same time, female migrants entering under familyreunification provisions may also have an easier time making eventual transitions into the labor market. Analyses show that Senegalese women who have configurations of legal status indicative of family reunification are more likely than women with other legal statuses to be economically inactive upon arrival, while there is little association between Senegalese men's legal status and their participation. The data also reveal, however, that family reunification does not preclude labor-market participation, as many of the women with family-reunification profiles eventually transition into economic activity.

Chapter 5 looks at the link between legal status and transnational activities. The literature on transnational activities has not sufficiently grappled with the role of physical mobility in the maintenance of affective ties that underlie non-mobile, long-distance transnational activities nor has it adequately examined the role of the state in constraining this geographical mobility. The legal constraint of irregular status may both physically confine migrants to the destination territory, decreasing homeland visits, and indirectly constrain other non-mobile transnational activities by reducing affective ties with origin communities through limited physical 
mobility. The MAFE data show that Senegalese migrants who lack secure legal status are effectively confined to the destination territory, making them unable to make short visits to the homeland. The reduced physical mobility resulting from this confinement short-circuits the entire social infrastructure underlying remitting and investing because the affective ties that underlie long-distance cross-border activities wither when migrants are unable to circulate. Analyses also reveal an important difference between household-based activities-remitting and investing-and the communal activity of hometown association participation, with the former being more responsive to the territorial confinement produced by irregular status.

\subsection{Senegal as a Strategic Site for Migration Research}

Senegal, a country of about 15 million people on the Atlantic coast of West Africa (U.S. Census Bureau 2018), has a long and diverse history of both intra- and intercontinental migration (see Fig. 1.1 for maps of Senegal's geographic relationship to West Africa and Western Europe). Like other sub-Saharan African countries, much migration from Senegal has been directed towards other African countries, and Senegalese migrants can be found in most regions of Africa (Bredeloup 2007; Flahaux et al. 2010). Senegal has also played a particularly large part in the recent evolution of sub-Saharan migration flows to Europe. While recent population estimates indicate that the former French colony accounts for approximately $4 \%$ of the population of West Africa (U.S. Census Bureau 2018), Senegalese made up $18 \%$ of West African migrants in the main European receiving countries in the early $2000 \mathrm{~s}$ (de Haas 2007), a figure that had increased to almost 20\% by 2010 (Organisation for
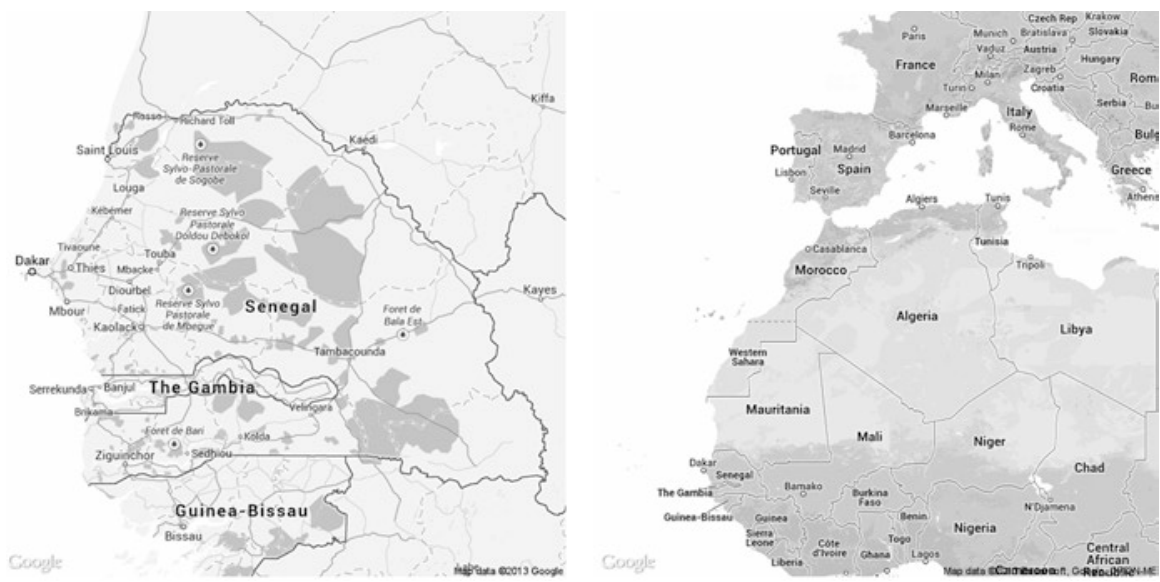

Fig. 1.1 Geographic position of Senegal in relationship to West Africa and Western Europe. (Notes: Map data @ 2013 Basaroft, Google, ORION-ME) 
Economic Co-operation and Development 2015). In addition to Senegalese migrants being disproportionately represented in Europe, Senegal stands out as a country that has diversified its migration destinations, with Senegalese increasingly present in Italy, Spain, and the United States as well as their traditional destination of France (de Haas 2007; Schoumaker et al. 2013). Senegal is now considered to be the source of one of the major "new African diasporas" (Koser 2003).

Senegalese migration to Europe offers an ideal opportunity to study the production and consequences of complex trajectories of irregularity in multiple contexts of reception. Although many Senegalese migrants travel to African destinations, most increasingly choose high-income destinations in Europe and North America (Schoumaker et al. 2013). There are especially high concentrations of Senegalese migrants in France, Italy, and Spain. These three countries account for $45 \%$ of the Senegalese emigrant population (Beauchemin and González-Ferrer 2011) and 86\% of the Senegalese resident in OECD countries in 2010 (Organisation for Economic Co-operation and Development 2015). Senegalese constitute the largest group of sub-Saharan African migrants in Italy and Spain and the second-largest group in France as of 2010 (Organisation for Economic Co-operation and Development 2015). In addition to the evolution of Senegalese migration towards new destinations, Senegalese migrants have faced variation in governmental policies, labor market conditions, and attitudes of the native-born towards immigrants in the main contexts of reception. All three countries have histories of tolerating or even encouraging illegal immigration and subsequent regularization while also stigmatizing and racializing illegal entry, residence, and work.

Although detailed data on irregular migrants by nationality are rare, Senegalese are thought to have high rates of irregularity. The Senegalese Ministry for Senegalese Abroad estimates that there are two undocumented Senegalese migrants for every documented Senegalese migrant (Di Bartolomeo et al. 2010). Recent research finds that almost $30 \%$ of Senegalese migrants in Europe lacked a residence permit during their year of arrival in European destinations, with $16 \%$ in irregular status at the time of the survey (Schoumaker et al. 2013). Senegalese were estimated to account for $18 \%$ of the undocumented sub-Saharan migrants in Spain prior to a regularization campaign in 2005 (de Haas 2008a). They are the largest group of West Africans regularized in Italy (de Haas 2008a) and were overrepresented in France's most recent regularization effort (Lessault and Beauchemin 2009b). In addition, Willems (2008) estimates that half of the 33,000 sub-Saharan Africans who arrived clandestinely in the Canary Islands in 2006 were Senegalese, with many of the boats leaving from the Senegalese coast. Senegal has thus become a major sender of migrants to Europe and has become linked with the phenomenon of undocumented migration.

In addition to Senegal's prominence in both intra- and intercontinental migration flows, it is clear that emigration profoundly shapes the demography, economy, and culture of Senegal itself. Daffé (2008) reports that emigrants made up approximately $4 \%$ of the 2005 Senegalese population, compared to $2.1 \%$ for sub-Saharan Africa as a whole; emigration rates to OECD destinations in 2010 were $3.2 \%$ for Senegal compared to $1.1 \%$ for all of sub-Saharan Africa (Xenogiani et al. 2015). 
The number of Senegalese emigrants increased by $1.8 \%$ per year between 2000 and 2005 and approximately one in ten Senegalese households counts at least one emigrant among its members (Daffé 2008). The economic impact of this migration flow is significant: official monetary remittances to Senegal stood at 10\% of GDP in 2008 after rising to $\$ 1.2$ billion from $\$ 305$ million in 2002 (Cisse 2011). Remittances have since increased by 58\% to $\$ 2.3$ billion in 2017 (World Bank Group 2017). Senegal ranks third in sub-Saharan Africa in the absolute value of remittance flows, behind only Nigeria and Ghana, while it ranks fifth in remittances as a percentage of GDP behind the smaller countries of Liberia, Comoros, the Gambia, and Lesotho (World Bank Group 2016). These flows of cash have reduced poverty in Senegal by $30 \%$ and have contributed positively to Senegal's macroeconomic accounting by equaling $40 \%$ of export earnings (Cisse 2011).

These demographic and economic impacts have emerged alongside what Massey et al. (1998) call a "culture of migration." Fieldwork in urban areas of Senegal found that fully half of men and $25 \%$ of women intended to leave their country, with many respondents arguing that emigration constitutes a rite of passage for young Senegalese (Willems 2008). Recent results from the Gallup World Poll echoed these findings, with $37 \%$ of Senegalese responding that they would move permanently to another country if given the opportunity; this share increased to $51 \%$ of those aged 15-24 (Xenogiani et al. 2015). Indeed, Tall argues that "the emigrant is perceived by Senegalese as a model of success" (2008: 37). This valorization of emigration takes place under the cloud of poor macroeconomic performance, declining real incomes, low human development, and high rates of poverty, all of which make emigration an attractive option for youth (Daffé 2008; Willems 2008).

While Senegalese emigrants were traditionally mostly of rural origin, Daffé (2008) reports the recent emergence of significant emigration from Senegal's cities: $59 \%$ of international migrants now come from urban zones. In contrast to the national average of $11 \%$ of households with migrants, almost $20 \%$ of households in the urban zones of Dakar and Touba had a member abroad and that $82 \%$ of these households received remittances (Daffé 2008). Tall (2008) argues that urban migrants have invested a large proportion of their foreign earnings in real estate, and that these visible (and occasionally ostentatious) signs of success have played a large role in creating the "culture of migration" that have increased emigration pressures in Senegal. 


\subsection{The Migration Between Africa and Europe (MAFE) Project}

The main data source of empirical data for the book is the Migration between Africa and Europe (MAFE) project. ${ }^{3}$ The MAFE project arose to fill a long-running gap in the availability of quantitative data on African migration (Beauchemin 2012, 2018). In general, the study of migration in many regions of the world has often been hampered by a lack of high-quality data. This is partly due to the myriad difficulties in studying migration, especially when compared to other demographic processes: while birth and death can only take place once for each person and in one place, migration can take place multiple times and, by definition, involves a change in geographic location. While a number of high-profile data-collection efforts have emerged during recent decades to start to fill the migration-data gap, most of these projects have focused on migration systems centered on the United States. The Mexican Migration Project (MMP) and the Latin American Migration Project (LAMP) have pioneered innovative multi-sited data collection techniques and have served as the basis of many of the studies that have defined the contours of our current knowledge on migration processes. Nonetheless, the dearth of individual-level, longitudinal data on African migration has been decried by scholars (Beauchemin 2012; Lucas 2006) and has remained an obstacle to scholarship: it has generally not been possible to test hypotheses developed in the U.S. migration system in an AfroEuropean context.

This lack of data has important repercussions for the study of legal status. Immigration-policy making and the elaboration of both external and internal immigration controls have rested on dramatic images of death-defying migration attempts or sensationalized portrayals of the living conditions of irregular migrants instead of solid scientific evidence on causes and consequences of African migration flows. These often-unfounded images have provided fodder for political debates on migration that have led to increasingly restrictive immigration policies across Europe (Düvell 2011a). It is widely acknowledged that immigration-control systems are out of sync with the realities of irregular migration. While control focuses on repressive border enforcement, the vast majority of irregular migrants-including irregular African migrants - are thought to enter Europe as tourists and subsequently overstay their visas (Schoumaker et al. 2013). Only reliable and comparative data on

\footnotetext{
${ }^{3}$ The MAFE project is coordinated by INED (C. Beauchemin) and is formed additionally by the Université catholique de Louvain (B. Schoumaker), Maastricht University (V. Mazzucato), the Université Cheikh Anta Diop (P. Sakho), the Université de Kinshasa (J. Mangalu), the University of Ghana (P. Quartey), the Universitat Pompeu Fabra (P. Baizan), the Consejo Superior de Investigaciones Científicas (A. González-Ferrer), the Forum Internazionale ed. Europeo di Ricerche sull'Immigrazione (E. Castagnone), and the University of Sussex (R. Black). The MAFE project received funding from the European Community's Seventh Framework Programme under grant agreement 217206. The MAFE-Senegal survey was conducted with the financial support of INED, the Agence Nationale de la Recherche (France), the Région Ile de France and the FSP programme 'International Migrations, territorial reorganizations and development of the countries of the South'. For more details, see: http://www.mafeproject.com/
} 
African migration can inform scholarly and policy debates on the scope and scale of forms of irregularity among African migrants.

The MAFE project aspired to collect comparative and representative data on subSaharan African migration using a multi-sited data collection methodology, with an emphasis on migration systems (Kritz et al. 1992) linking Africa and Europe in which people, culture, money, and ideas circulate transnationally. The project, in its methodology and scientific objectives, recognized the increasingly complex trajectories of African migrants and thus emphasized that migration is not a unidirectional event (hence the choice of the preposition "between" in the project's name). Its innovative focus thus explicitly allows for the study of circulation, return migration, and transnational practices.

The project chose to focus on three discrete sub-systems of the Afro-European migration system, focused on the African countries of Senegal, Ghana, and the Democratic Republic of the Congo (DRC). These countries represent three of the four largest populations of sub-Saharan Africans in Europe, thus making them numerically important populations to study (Beauchemin 2012). The countries were also chosen because of the variation they offer: they have different colonial backgrounds and thus different traditional migration destinations and their economic, ecological, and political conditions differ.

The project selected multiple European destinations for each of these African hubs, including the former colonial power and one or more new destinations. For Senegal, France is the former colonial power and Italy and Spain are new destinations; for Ghana, Great Britain is the traditional destination and the Netherlands is the new destination; and for the DRC, Belgium is the former colonial power and Great Britain the new destination. This choice of destinations allows for the examination of changing patterns of migration over time and also creates the variation in contexts of exit and reception necessary for comparative studies (Beauchemin 2012). As this book uses only the data from the Senegalese sub-sample, further discussions of the MAFE project will be limited to the Senegalese case.

\subsubsection{Sampling Design of the MAFE Project}

One of the major goals of the MAFE project was to produce representative sociodemographic data for both the sub-Saharan African origin countries and the European destination countries. The MAFE project thus employed a multi-site design, collecting data on both current migrants in European countries and nonmigrants and returned migrants in the country of origin. This design overcomes the limitations of surveys only at origin — such as reliance on proxy respondents-or only at destination - such as the exclusion of non-migrants or returned migrantsand thus avoids sample-selection problems that plague much research on migration (Beauchemin 2012, 2018).

The MAFE sample in Senegal was drawn from the region of Dakar, the Senegalese capital city, and its administrative departments of Dakar, Pikine, 
Guediawaye, and Rufisque. Approximately 25\% of Senegal's population lives in this region, and it accounted for more than a quarter of all of the country's international emigration departures in the 5 years prior to 2002 (Mezger Kveder 2012). The project, which collected its data in 2008, employed a three-stage probabilistic sampling design to construct a sample of households within the region, oversampling those households with migration experience and using the 2002 population census as a sampling frame to select primary sampling units. Census districts served as the primary sampling units and were divided into ten strata of equal size based on migration prevalence. Six census districts were randomly selected from each stratum, and the project enumerated households within each selected district and divided them into migrant and non-migrant strata. The project then randomly selected 11 households from each stratum in each district, or 1320 total households, for participation in the survey. Of the selected households, 1141 completed a household questionnaire $(87 \%)$, with an $11 \%$ refusal rate.

The household questionnaire generated a list of household members, defined as individuals who had lived for at least 6 months in the household at the time of the survey or plan on living there for at least 6 months. This list of household members served as a sampling frame for the individual survey and the project randomly selected at most two returned migrants, two spouses of migrants, and one nonmigrant per household for participation. Individuals had to meet the following criteria in order to participate: (1) be between 25 and 75 years old; (2) have been born in Senegal; and (3) currently hold or in the past have held Senegalese citizenship. A total of 1338 individuals were selected and the project completed 1062 interviews. The majority of non-response was due to lack of ability to locate the individual after repeated attempts. The Senegalese sample as thus constructed is representative of households and individuals in the Dakar region.

The main challenge in collecting data on migrants in a destination is the lack of a suitable sampling frame. Migrants, especially those who lack regular legal status, may not be systematically recorded in population registers that, if they are even available, could otherwise serve as sampling frames. Migrants also tend to be a hard-to-reach population (Mezger Kveder 2012). The MAFE project thus used a variety of methods to construct a sample of Senegalese migrants as representative as possible of the population of Senegalese living in each destination country. The main approach in France and Italy was the quota method: using auxiliary data about the population of Senegalese in each destination country, the project set quotas for the number of respondents by different characteristics, including gender, age, region of residence, and socioeconomic status (Beauchemin 2012, 2018). The project also varied the recruitment methods (via Senegalese associations and snowballing techniques) and places (such as metro stations, hairdressers' shops, and public places) so that the selection biases of each method would, in theory, cancel each other out.

In Spain, however, the MAFE project had the advantage of a sampling frame in the Padrón Municipal. Inclusion in this municipal population register gives migrants—even those with irregular status—access to a variety of benefits, meaning that most foreigners are on the list. In addition, the project attempted to contact migrants in Europe using information collected from households in Senegal. This 
matched sampling strategy met with only limited success, however, and thus accounts for a small proportion of migrants interviewed in Europe (Beauchemin and González-Ferrer 2011).

In all three European countries, sampling was limited to selected regions that incorporated between $64 \%$ and $75 \%$ of all Senegalese migrants living in the countries. Individuals were eligible for participation if they met the criteria described above for participation in the individual survey; in addition, in an attempt to exclude migrants of the 1.5 generation, individuals had to have migrated to Europe for the first time at age 18 or later. The project successfully collected about 200 interviews each in France, Italy, and Spain. The MAFE project team computed a variety of weights for use in accounting for sampling design (Schoumaker and Mezger 2013).

\subsubsection{MAFE Questionnaires ${ }^{4}$}

The MAFE project administered a household questionnaire to the head of each selected household in Dakar and a biographical questionnaire to each individual selected to participate in the study either in Senegal or in Europe. The household head responded to questions for all individuals currently living in the household, and also for all other children of the household head not physically living in the household, as well as current migrants who were related to the head, the head's spouse, or the spouse of a household member. The proxy data thus collected for each individual included education, occupation, religion, ethnicity, and past and current migrations (including destination and years of departure and return), and links with current migrants. The questionnaire also collected household-level data on housing characteristics and ownership of durable assets.

The biographical questionnaire was administered to individuals in all project countries. Its goal was to permit the reconstruction of the respondent's life history in multiple domains in a coherent fashion. The questionnaire thus consisted of two data-collection tools: (1) a biographical event grid or life-history calendar tied to the age of the respondent and the corresponding calendar year in which the interviewer recorded the respondent's life events; and (2) a questionnaire with both a set of open questions that helped to fill in the basic structure of the calendar and a variety of modules with structured questions. The biographical questionnaire collected a wide array of information on each respondent. Traditional life-history data included family history (relationships and children), residential history (places of residence of a year or more), education, occupation, and asset ownership; these modules were applicable to migrants and non-migrants alike. Family events were recorded early in the interview as they are usually the easiest to recall; this personal history thus then provides a temporal "backbone" that can aid recall for the rest of the questionnaire.

\footnotetext{
${ }^{4}$ All MAFE questionnaires are available at http://mafeproject.site.ined.fr/en/methodo/methodo/
} 
In keeping with the survey's focus on migration, the questionnaire also included a number of modules about migration events and experiences, including migration attempts; long and short stays outside of Senegal; long and short return trips to Senegal; migration experience of friends and relatives; citizenship history; asylum claims; work and residence permits; money transfers; and participation in migrant associations. All modules asked the respondent to indicate dates for events, allowing the transcription of information into the life-history calendar at annual intervals.

\subsubsection{Advantages of the MAFE Data}

This book will use the data collected by the MAFE biographical questionnaires. These data have a number of advantages for the study of the determinants and consequences of legal statuses of current and former Senegalese migrants in Europe.

\section{Inclusion of Regular and Irregular Migrants}

First of all, the sampling design purposefully includes both regular and irregular migrants. The Padrón in Spain offered the opportunity to include both documented and undocumented Senegalese migrants in the sample, and the project also made effort in France and Italy to include undocumented migrants in the sample in order to avoid the biases that excluding this population would bring about (Beauchemin 2012, 2018). Descriptive statistics in Table 1.1 indicate that the project was successful in including this traditionally hard-to-reach population: across the three European countries, almost $18 \%$ of the respondents lacked a residence permit at the time of the survey, while almost $60 \%$ had lacked this authorization at some point in the past. The percentages vary by country, with a higher proportion of currently undocumented migrants in the Spanish and Italian samples than in the French sample.

Table 1.1 Percentage of Senegalese migrants without a residence permit at selected time points, MAFE-Senegal

\begin{tabular}{l|l|l}
\hline Country & $\begin{array}{l}\text { Time of } \\
\text { survey }\end{array}$ & Ever \\
\hline France & 10.5 & 32.8 \\
\hline Italy & 19.4 & 67.7 \\
\hline Spain & 24.8 & 74.3 \\
\hline Total & 18.3 & 58.4 \\
\hline
\end{tabular}

Source: MAFE-Senegal

Notes: Unweighted percentages of respondents declaring that they did not hold a residence permit 


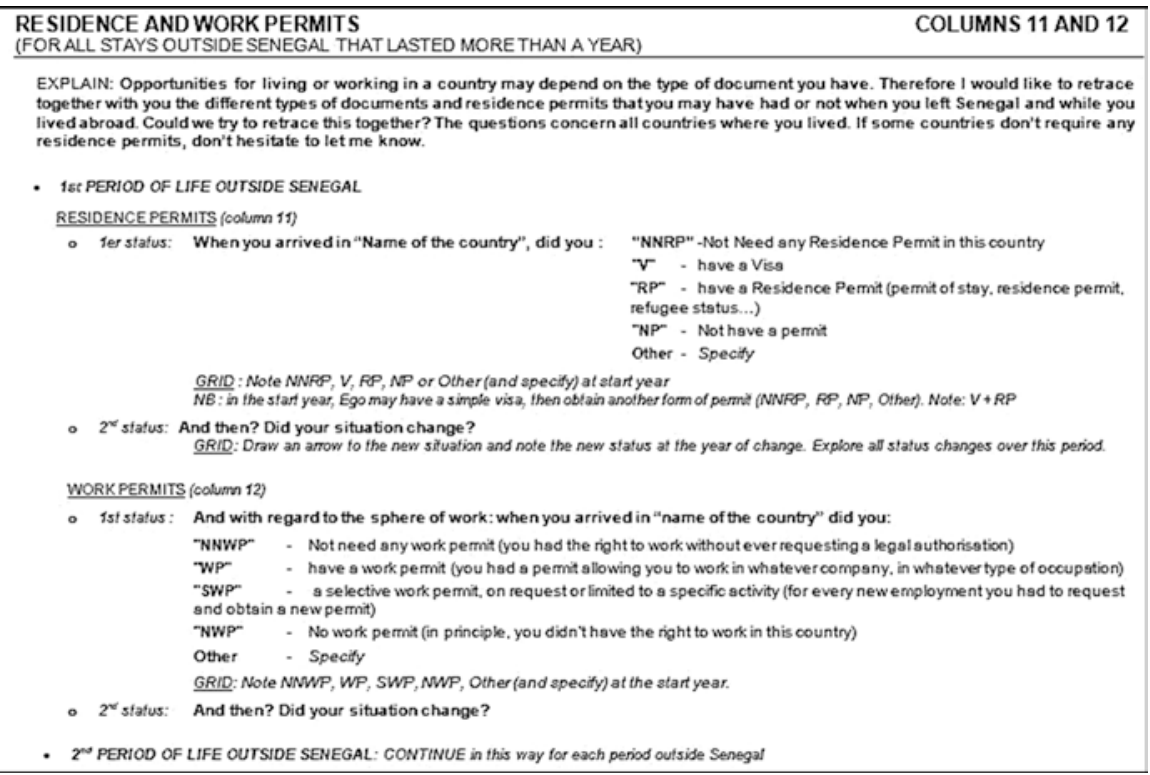

Fig. 1.2 MAFE-Senegal biographical questionnaire module on legal statuses

\section{Longitudinal Measurement of Legal Status}

In addition to making efforts to include migrants with irregular experience in the sample, the MAFE project also included a module in the biographical questionnaire that allowed for the collection of longitudinal, comparable data on legal statuses. Figure 1.2 displays the questions ${ }^{5}$ the interviewer used to elicit information about legal statuses over time from the respondent. Starting with the first period of residence outside of Senegal, the interviewer asked that respondent to indicate the combination of visa, residence permits, and work permits that the individual had upon arrival. The interviewer recorded this information, including any combinations of permits specified by the individual, in the life-history calendar at the year corresponding the migrant's arrival in the destination. The interviewer then asked if the individual's situation with regard to both residence and work authorizations changed during the first period of residence outside of Senegal and recorded any changes in the life-history calendar. The interviewer repeated this cycle of questions for each period of residence outside of Senegal. The MAFE data thus include data on Senegalese migrants' legal statuses in the domains of entry, residence, and work for each year of residence in each of the foreign countries in which they lived.

\footnotetext{
${ }^{5}$ The English-language version of these questions appeared in the Ghana biographical survey, adapted here for Senegal for the convenience of Anglophone readers. The questions in the Senegal biographical survey were identical and were posed in French, Italian, or Spanish.
} 
These kinds of longitudinal data on legal statuses are both rare and important. Very few data sources on migrants in Europe include information on legal status, either because the data are pulled from population registers that include only legal migrants or because the sampling scheme includes potentially undocumented migrants but the questionnaire does not ask about legal status (Amuedo-Dorantes et al. 2013). Given the debate about undocumented migrants in both the US and in Europe (Düvell 2011a; Massey et al. 2002), however, collecting data on legal status is important. Migration scholars have started calling for longitudinal data on legal statuses in particular, which are necessary to answer questions about transitions over time between various legal statuses (Donato and Armenta 2011; Massey and Capoferro 2004) and combinations between different kinds of authorizations. Timevarying indicators of legal statuses are also necessary as predictor variables of timevarying outcomes, such as employment and remitting, that may be linked to entry, residence, and work authorization. The MAFE-Senegal data provide such longitudinal data on a rich array of variables measuring legal statuses.

\section{Comparability of Legal Statuses}

The data on legal statuses collected by the MAFE project are also comparable both across countries and over time. While MAFE ensured basic comparability by using the same carefully translated questionnaire in all survey locations, the multi-sited survey design combined with a retrospective questionnaire required a deeper level of conceptual comparability. Concepts measured by the questionnaire had to be understandable and relevant in multiple contexts over different geographic locations, time periods, languages, and personal histories. As Beauchemin (2012, 2018) points out, some concepts lent themselves easily to this kind of comparability, either because they are universal or because standard solutions exist (such as the International Standard Classification of Occupations or ISCO, which MAFE used to code occupations). Measuring legal statuses was a case in which contextual specificities required the invention of a standardized framework.

Each country has its own set of laws regulating the entry, residence, and work of foreigners, and the authorizations are rarely comparable. The alphabet soup of visas for entering and residing in the United States, for example, does not have an exact analog in Europe. Even European countries differ greatly in their external and internal mechanisms of immigration control (Brochmann and Hammar 1999) despite the attempts of the European Union to harmonize migration policies. Indeed, immigration-policy making is a fiercely guarded realm of national sovereignty in Europe. Laws and regulations defining legal statuses can also vary over time within the same country, thus making comparability over time difficult and complicating retrospective data collection (Beauchemin 2012, 2018).

The MAFE project thus adopted a flexible strategy to capture all of the legal situations of Senegalese migrants at all times and places: the project assumed that visas, residence permits, and work permits were the basic mechanisms of immigration control to which migrants are subject. The questionnaire did not differentiate 
between different kinds of visas, residence, or work permits that may be specific to a time period or destination. By asking about visas, residence, and work permits separately and encouraging migrants to list all authorizations and changes in authorizations, the questionnaire was as exhaustive and comprehensive as possible. In addition, migrants had the possibility of answering that they did not need a permit, reflecting the complicated evolution of immigration-control legislation vis-à-vis Senegalese in France.

\subsubsection{Limitations of the MAFE Data}

While the MAFE project has generated rich, longitudinal, multi-sited and comparable data that can be used to study the determinants and consequences of the legalstatus trajectories of Senegalese migrants in Europe, the data also have a number of limitations stemming from compromises in the survey design.

\section{Sample Size}

Because of cost considerations, the inherent difficulty in sampling a hard-to-reach population, and the lack of availability of a sampling frame, the MAFE project set a goal of interviewing 200 Senegalese migrants in each of the three destination countries (Beauchemin 2012, 2018). The sample is of a reasonable size when pooled, especially if non-migrants interviewed in Senegal are included in the analysis, which would give a sample size of 1668 individuals and almost 70,000 personyears. The relatively small sample sizes in each country, however, limit the ability to conduct destination-specific analyses.

\section{Recall Bias}

The second compromise was the retrospective nature of the data collection, which leads to the potential limitation of recall bias. Collecting longitudinal and timespecific information on migration-related events that would allow analyses of determinants of migration was an important objective for the project, and a retrospective design was more cost-effective than a prospective panel for doing so (Beauchemin 2012, 2018). In addition, the retrospective survey could ensure a representative sample at the time of the data collection, while a panel survey loses representativeness through attrition over time (Mezger Kveder 2012). Nonetheless, retrospective data collection does open the door to the possibility of recall bias in the reporting of past events. Respondents had an average age of 40 years at the time of data collection, meaning that there was likely a considerable effort involved in remembering life histories. 
Mezger Kveder (2012) argues that this effort can result in measurement error through the misreporting of the timing of events or the complete omission of events. Research has shown that this recall bias depends, in part, on the kind of event being recalled. Respondents tend to remember rare events readily because of their relative salience (Eisenhower et al. 2004), which means that events like births and marriages should be subject to less recall bias (Poulain et al. 1992). Residential histories tend to present more difficulty in recall especially if the exact timing is of interest (Poulain et al. 1992), but respondents seem to have less difficulty in accurately reporting migration events, especially if the move is long-distance (Smith and Thomas 2003). Recall bias in other areas seems to be more problematic: unemployment spells, for example, tend to be underreported, even in shorter reference intervals (Horvath 1982; Manzoni et al. 2011).

In addition to these substantive variations in recall bias, research has shown that time since the event seems to have a non-linear relationship to recall accuracy, with a deterioration in recall stabilizing over time (Mayer 2007); overall age also seems to be associated with decreased recall accuracy (Haaga 1988). The MAFE project sought to limit recall biases by using salient events - such as birth or marriage - to anchor the life history calendar and encouraged respondents to think about event timing in relation to these anchor events (Beauchemin 2012, 2018). The interviewers also had an array of dated local, national, and world events that could also serve as recall anchors.

The effect of recall bias on the reporting and measurement of legal statuses has not been examined, most likely because there is no source of prospective data on legal statuses to compare with retrospective sources. The main concern is that reporting of legal status may be prone to measurement error through misreporting of timing or omission of changes in legal status. The existing research on recall bias suggests, though, that legal status might be a domain where there is little recall bias. Given the widespread knowledge throughout Senegal of the external immigration controls in the form of visa requirements of most European countries (Willems 2008), it is reasonable to assume that legal vs. unlawful status upon entry would be a salient feature that migrants would recall with accuracy. Still, this may not be true in respect to those who still enjoyed visa-free travel to France or Italy (see Chap. 2) or in respect to persons who were only marginally involved in the organization of travel, such as children but perhaps also reunified spouses.

First residence and work authorizations, which are linked in time to the year of arrival at a given destination, may also be a salient feature in migrants' memories. Recall may become more difficult for some subsequent changes in legal status. Transitions from regular to irregular states via the expiration of a permit for which the migrant does not need to take concrete action may be associated with fuzzier recall. Renewals of permits or acquisition of regular status, on the other hand, are likely to be salient events if only because of the bureaucratic paperwork often involved in these processes (Spire 2005). In addition, the MAFE data show transitions between different legal statuses once in a destination to be somewhat rare: the average Senegalese migrant reports 1.73 legal-status spells, or 0.73 transitions; more than half never experience a change in legal status. Thus, most migrants do 
not face great challenges in their recall of their legal statuses, which are also most likely salient.

\section{Time Resolution}

The third compromise stemming from the survey design was the choice of retrospective time resolution. The project decided on yearly intervals for recording events as a way to both simplify data collection and limit response burden (Beauchemin 2012, 2018). While this produces life histories of adequate length for analysis, the time interval may obscure events and changes of state that happen during that year. The questionnaire allows for some recording of multiple events at the same time but does not necessarily allow for the recording of the precise ordering of events. Even if only one event of interest happened during the year, the time resolution does not allow the establishment of temporal precedence vis-à-vis other events that occurred in the same year. These issues may be particularly relevant for legal statuses, as migrants may experience multiple status transitions in a given year, especially if they have short-term permits. Thus, the survey may conceal some instability in migrants' legal trajectories (Beauchemin 2012, 2018). The time resolution issue also affects other variables under study in this book: migrants may engage in transnational activities, such as remitting, multiple times during a year; migrants may also experience multiple spells of employment and unemployment during the same year.

\section{Standardization of Heterogeneous Legal Statuses}

The fourth compromise arising from the design of the survey was the necessary standardization of questionnaire items, including those asking about legal status. While this standardization is an advantage in that it allows comparison across time and between countries, it also creates a gap between the data collected and the legal reality in each time period and destination. For example, residence and work permits are often differentiated by length of validity and conditions for renewal, distinctions which often correspond to "temporary" and "permanent" permits with different connotations for the stability and longevity of residence. Spire (2005) argues that these kinds of distinctions were used to create a hierarchy of more- and less-desirable immigrants in France. The former were granted permanent residence with long periods of authorization and few occupational or geographic restrictions, while the latter obtained only short, precarious authorizations. Italy and Spain have also recently introduced longer-term "permanent" residence permits (see Chap. 2), access to which is often difficult and dependent on continuous prior regular status.

There is thus clearly important heterogeneity even within the category of "regular" migrants: those with temporary authorizations are more precarious than those with permanent authorizations. The MAFE project only collected standardized data on the possession of residence and work permits and did not allow for the 
differentiation of different kinds of permits. The survey recorded the length of different spells of authorization, so some indication of the precarity of statuses is possible, but there is no straightforward way to match spell length with different kinds of authorization. As a result, there is a degree of unobserved heterogeneity that is unavoidable.

In addition to the lack of information about the kind of entry, residence, and work authorizations, the study's standardized approach did not permit the collection of information about the mechanisms by which migrants acquired or lost their legal statuses. Senegalese migrants may have entered the destination country on a tourist, work, or family-reunification visa, and residence and work permits may have come from regularization programs or marriage. While auxiliary data on the timing of other life or national events could help construct indicators of different types of mechanisms of access to regular statuses, the lack of direct observation of these mechanisms is a limitation. Standardization also limited the ability to collect data on more convoluted legal arrangements, such common Senegalese strategy of using false documents (either counterfeit or belonging to someone else) (Spire 2005).

\section{The Murkiness of Legal Status}

Finally, there are some potential sources of bias in data on legal statuses that stem not so much from the design of the MAFE survey as from the very nature of legal statuses themselves. Immigration policies and the mechanisms of control they define are complex and multifaceted, and the bureaucracies that administer them are equally complex. It is possible that migrants may not fully understand the details of their past and/or current legal statuses. While the standardization of the legal-status instruments in the MAFE survey may help overcome this issue, it is still possible that there is some misreporting of legal status due to simple misunderstanding.

For example, Senegalese migrants in France in the 1960s needed neither a visa for legal entry nor a residence permit for legal residence, but technically needed a work permit and a contract for work-related migration; many Senegalese thus entered and resided legally without any authorization and subsequently found work and were often regularized post facto. A migrant recalling this situation might declare not needing a visa or a residence permit but not having a work permit (and then having one); s/he could also declare not having any form of authorization or, on the contrary, having all of the forms of authorization. There is thus probably some degree of a gap between legal statuses as they exist in the law and legal statuses as they exist in migrants' comprehension of them.

Bias could also arise from migrants underreporting irregular status because of the fear of deportation if the data were revealed to public authorities. The MAFE project made great efforts to assure respondents of the confidentiality of their personal data, though, and the prevalence of migrants who reported current or past irregular status (see Table 1.1) indicates that this fear did not prevent reporting of irregularity. In any event, even if underreporting occurred, the estimates in this book could then be considered conservative lower bounds. 
Despite these limitations, most assessments of the MAFE project's approach (Beauchemin 2012, 2018; Center for Global Development 2009; Mezger Kveder 2012; Toma 2012) conclude that it is furnished a unique dataset which takes a step towards filling the gap in the availability of quantitative data on African migration. Not only is it, like other migration datasets, certainly "better than nothing" (Beauchemin 2012: 36), but it is offers information on a rich array of topics that permit investigation of a large number of questions in migration research. The data are especially valuable for studying legal statuses, the contexts of reception that produce them, and the impacts that they have on Senegalese migrants' lives.

\section{References}

Agency for Fundamental Rights. (2011). Fundamental rights of migrants in an irregular situation in the European Union: Comparative report. Luxembourg: Publication Office of the European Union.

Alba, R. D., \& Nee, V. (2003). Remaking the American mainstream: Assimilation and contemporary immigration. Cambridge, MA: Harvard University Press.

Amuedo-Dorantes, C., Malo, M. A., \& Muñoz-Bullón, F. (2013). New evidence on the impact of legal status on immigrant labor market performance: The Spanish case. LABOUR, 27(1), 93-113.

Anderson, B. (2010). Migration, immigration controls and the fashioning of precarious workers. Work, Employment \& Society, 24, 300-317.

Bean, F. D., Edmonston, B., \& Passel, J. S. (1990). Undocumented migration to the United States: IRCA and the experience of the 1980s. Washington, DC: Urban Inst Press.

Beauchemin, C. (2012). Migrations between Africa and Europe: Rationale for a survey design. Methodological Note (Vol. 5). Paris: INED.

Beauchemin, C. (Ed.). (2018). Migration between Africa and Europe. New York: Springer Berlin Heidelberg.

Beauchemin, C., \& González-Ferrer, A. (2011). Sampling international migrants with origin-based snowballing method: New evidence on biases and limitations. Demographic Research, 25, 103-134.

Beauchemin, C, \& Lamboni, M. (2017). Explaining the transition toward irregularity: A comparative longitudinal analysis of three Sub-Saharan flows in Europe, p. 19 in Chicago.

Borjas, G. J., \& Tienda, M. (1993). The employment and wages of legalized immigrants. International Migration Review, 27(4), 712-747.

Bradatan, C. E., \& Sandu, D. (2012). Before crisis: Gender and economic outcomes of the two largest immigrant communities in Spain. International Migration Review, 46(1), 221-243.

Bredeloup, S. (2007). La diams'pora du fleuve Sénégal : sociologie des migrations africaines. Toulouse/Paris: IRD éditions.

Brochmann, G. (1999). The Mechanisms of control. In G. Brochmann \& T. Hammar (Eds.), Mechanisms of immigration control: A comparative analysis of European regulation policies (pp. 1-27). Oxford: Berg.

Brochmann, G., \& Hammar, T. (Eds.). (1999). Mechanisms of Immigration control: A comparative analysis of European regulation policies. Oxford: Berg.

Center for Global Development. (2009). Migrants count: Five Steps toward better migration data. Report of the commission on international migration data for development research and policy. Washington, D.C.: Center for Global Development.

Cisse, F. (2011). Senegal. In S. Mohapatra \& D. Ratha (Eds.), Remittance markets in Africa. Washington, D.C.: World Bank Publications. 
Collier, P. (2013). Exodus: How migration is changing our world (1st ed.). Oxford/New York: Oxford University Press.

Connor,P.(2018).Internationalmigrationfromsub-SaharanAfricahas growndramatically since 2010. Pew Research Center. Retrieved July 9, 2018 http://www.pewresearch.org/fact-tank/2018/02/28/ international-migration-from-sub-saharan-africa-has-grown-dramatically-since-2010/

Connor, P., \& Massey, D. S. (2010). Economic outcomes among Latino Migrants to Spain and the United States: Differences by source region and legal status. International Migration Review, 44(4), 802-829.

Cvajner, M., \& Sciortino, G. (2010). Theorizing irregular migration: The control of spatial mobility in differentiated societies. European Journal of Social Theory, 13(3), 389-404.

Daffé, G. (2008). Les Transferts d'argent Des Migrants Sénégalais: Entre Espoir et Risques de Dépendance. In M.-C. Diop (Ed.), Le Sénégal Des Migrations: Mobilités, Identités Et Sociétés, Hommes et sociétés (pp. 105-131). Paris: Karthala.

De Genova, N. (2002). Migrant 'illegality' and deportability in everyday life. Annual Review of Anthropology, 31(1), 419-447.

De Genova, N. (2005). Working the boundaries: Race, space, and "illegality" in Mexican Chicago. Durham: Duke University Press.

de Haas, H. (2007b). The Myth of Invasion: Irregular migration from West Africa to the Maghreb and the European Union. IMI Research Report. Oxford: International Migration Institute, University of Oxford.

de Haas, H. (2008a). Irregular migration from West Africa to the Maghreb and the European Union: An overview of recent trends. Geneva: International Organization for Migration.

de Haas, H. (2008b). The myth of invasion: The inconvenient realities of African migration to Europe. Third World Quarterly, 29(7), 1305.

Di Bartolomeo, A., Fakhoury, T., \& Perrin, D. (2010). CARIM migration profile, Senegal. Consortium for applied research on international migration.

Diehl, C., \& Schnell, R. (2006). 'Reactive ethnicity' or 'assimilation'? Statements, arguments, and first empirical evidence for labor migrants in Germany. International Migration Review, 40(4), 786-816.

Donato, K. M., \& Armenta, A. (2011). What we know about unauthorized migration. Annual Review of Sociology, 37, 529-543.

Durand, J., Massey, D. S., \& Pren, K. A. (2016). Double disadvantage unauthorized Mexicans in the U.S. Labor market. The ANNALS of the American Academy of Political and Social Science, 666(1), 78-90.

Düvell, F. (2008). Clandestine migration in Europe. Social Science Information, 47(4), 479-497.

Düvell, F. (2011a). Paths into irregularity: The legal and political construction of irregular migration. European Journal of Migration and Law, 13(3), 275-295.

Düvell, F. (2011b). The pathways in and out of irregular migration in the EU: A comparative analysis. European Journal of Migration and Law, 13(3), 245-250.

Eisenhower, D., Mathiowetz, N. A., \& Morganstein, D. (2004). Recall error: Sources and bias reduction techniques. In P. P. Biemer, R. M. Groves, L. E. Lyberg, N. A. Thiowetz, \& S. Sudman (Eds.), Measurement errors in surveys (pp. 125-144). New York: Wiley.

Ersanilli, E., \& Koopmans, R. (2010). Rewarding integration? Citizenship regulations and the socio-cultural integration of immigrants in the Netherlands, France and Germany. Journal of Ethnic and Migration Studies, 36(5), 773-791.

Ersanilli, E., \& Koopmans, R. (2011). Do immigrant integration policies matter? A three-country comparison among Turkish immigrants. West European Politics, 34(2), 208-234.

Espenshade, T. J. (1995). Unauthorized immigration to the United States. Annual Review of Sociology, 21, 195-216.

Flahaux, M.-L., Beauchemin, C., \& Schoumaker, B. (2010). Partir, Revenir : Tendances et Facteurs Des Migrations Africaines Intra et Extra-Continentales. MAFE Working Papers (Vol. 7). Paris: INED. 
Fokkema, T., \& Haas, H. (2015). Pre- and post-migration determinants of socio-cultural integration of African immigrants in Italy and Spain. International Migration, 53(6), 3-26.

Gerdes, J., \& Reisenauer, E. (2012). From return-oriented to integration-related transnationalisation: Turkish migrants in Germany. Revue Européenne Des Migrations Internationales, 28(1), 107-128.

Greenman, E., \& Hall, M. (2013). Legal status and educational transitions for Mexican and Central American immigrant youth. Social Forces, 91(4), 1475-1498.

Haaga, J. G. (1988). Reliability of retrospective survey data on infant feeding. Demography, 25(2), 307-314.

Hatton, T. J., \& Williamson, J. G. (2003). Demographic and economic pressure on emigration out of Africa. The Scandinavian Journal of Economics, 105(3), 465-486.

Horvath, F. W. (1982). Forgotten unemployment: Recall bias in retrospective data. Monthly Labor Review, 105(3), 40-43.

Koser, K. (2003). New African diasporas. London: Routledge.

Kossoudji, S. A., \& Cobb-Clark, D. A. (2000). IRCA's impact on the occupational concentration and mobility of newly-legalized Mexican men. Journal of Population Economics, 13(1), 81-98.

Kraler, A. (2009). Regularisation: A misguided option or part and parcel of a comprehensive policy response to irregular migration? (Vol. 24). Vienna: IMPCD.

Krause, K. (2008). Transnational therapy networks among Ghanaians in London. Journal of Ethnic \& Migration Studies, 34(2), 235-251.

Kritz, M. M., Lim, L. L., \& Zlotnik, H. (1992). International migration systems : A global approach. Oxford/New York: Clarendon Press/Oxford University Press.

Lee, T. L., \& Fiske, S. T. (2006). Not an outgroup, not yet an ingroup: Immigrants in the stereotype content model. International Journal of Intercultural Relations, 30(6), 751-768.

Lessault, D., \& Beauchemin, C. (2009a). Ni invasion, ni exode. Regards statistiques sur les migrations d'Afrique subsaharienne. Revue Européenne des Migrations Internationales, 25(1), 163-194.

Lessault, D., \& Beauchemin, C. (2009b). Ni invasion, ni exode: Regards statistiques sur les migrations d'Afrique subsaharienne. Revue Européenne des Migrations Internationales, 25(1), 163-194.

Lucas, R. E. B. (2006). Migration and economic development in Africa: A review of evidence. Journal of African Economies, 15(Supplement 2), 337-395.

Manzoni, A., Luijkx, R., \& Muffels, R. (2011). Explaining differences in labour market transitions between panel and life-course data in West-Germany. Quality \& Quantity, 45(2), 241-261.

Marrow, H. B. (2013). Undocumented residents in the United States. In The encyclopedia of global human migration. Chichester: Blackwell Publishing Ltd.

Massey, D. S. (2007). Categorically unequal: The American stratification system. New York: Russell Sage Foundation.

Massey, D. S., \& Bartley, K. (2006). The changing legal status distribution of immigrants: A caution. International Migration Review, 39(2), 469-484.

Massey, D. S., \& Capoferro, C. (2004). Measuring undocumented migration. International Migration Review, 38(3), 1075-1102.

Massey, D. S., \& Singer, A. (1995). New estimates of undocumented Mexican migration and the probability of apprehension. Demography, 32(2), 203-213.

Massey, D. S., Arango, J., Hugo, G., Kouaouci, A., Pellegrino, A., \& Edward Taylor, J. (1998). Worlds in motion: Understanding international migration at the end of the millennium. Oxford: Clarendon Press.

Massey, D. S., Durand, J., \& Malone, N. J. (2002). Beyond smoke and mirrors: Mexican immigration in an era of economic integration. New York: Russell Sage Foundation.

Mayer, K. U. (2007). Retrospective longitudinal research: The German Life history study. In S. Menard (Ed.), Handbook of longitudinal research: Design, measurement, and analysis. San Diego: Elsevier. 
Mazzucato, V. (2008). The double engagement: Transnationalism and integration. Ghanaian migrants' lives between Ghana and The Netherlands. Journal of Ethnic and Migration Studies, 34(2), 199.

McKay, S., Markova, E., \& Paraskevopoulou, A. (2011). Undocumented workers' transitions : Legal status, migration, and work in Europe / Sonia McKay, Eugenia Markova, and Anna Paraskevopoulou. New York: Routledge.

Menjívar, C. (2009). Who belongs and why. Society, 46(5), 416-418.

Menjívar, C., \& Kanstroom, D. (2014). Constructing immigrant "illegality": Critiques, experiences, and responses. Cambridge: Cambridge University Press.

Mezger Kveder, C. L. (2012). Essays on migration between Senegal and Europe: Migration attempts, investment at origin and returnees' occupational status. Doctoral thesis, University of Sussex.

Organisation for Economic Co-operation and Development. (2015). Database on immigrants in $O E C D$ and non-OECD countries (DIOC). Paris: OECD.

Østergaard-Nielsen, E. (2003). The politics of migrants' transnational political practices. International Migration Review, 37(3), 760-786.

Phillips, J. A., \& Massey, D. S. (1999). The new labor market: Immigrants and wages after IRCA. Demography, 36(2), 233-246.

Portes, A. (1978). Introduction: Toward a structural analysis of illegal (undocumented) immigration. International Migration Review, 12(4), 469-484.

Portes, A. (1979). Illegal immigration and the international system, lessons from recent legal Mexican immigrants to the United States. Social Problems, 26(4), 425-438.

Portes, A., \& Böröcz, J. (1989). Contemporary immigration: Theoretical perspectives on its determinants and modes of incorporation. International Migration Review, 23(3), 606-630.

Portes, A., \& Rumbaut, R. (2001). Legacies: The story of the immigrant second generation. Berkeley: University of California Press.

Portes, A., \& Rumbaut, R. (2006). Immigrant America: A portrait (3rd ed., rev.expanded, and update). Berkeley: University of California Press.

Poulain, M., Riandey, B., \& Firdion, J.-M. (1992). Data from a life history survey and from the Belgian population register: A comparison. Population: An English Selection, 4, 77-96.

Riccio, B. (2001). From 'ethnic group' to 'transnational community'? Senegalese migrants' ambivalent experiences and multiple trajectories. Journal of Ethnic and Migration Studies, 27, 583-599.

Riccio, B. (2008). West African transnationalisms compared: Ghanaians and Senegalese in Italy. Journal of Ethnic \& Migration Studies, 34(2), 217-234.

Ruhs, M., \& Anderson, B. (2010). Semi-compliance and illegality in migrant labour markets: An analysis of migrants, employers and the state in the UK. Population, Space and Place, 16(3), 195-211.

Schoumaker, B., \& Mezger, C. (2013). Sampling and computation weights in the MAFE surveys. 6. Institut national d'études démographiques.

Schoumaker, B., Flahaux, M.-L., Schans, D., Beauchemin, C., Mazzucato, V., \& Sakho, P. (2013). Changing patterns of African migration: A comparative analysis. MAFE Working Paper 18 (Vol. 18). Paris: INED.

Schoumaker, B., Flahaux, M.-L., Beauchemin, C., Schans, D., Mazzucato, V., \& Sakho, P. (2018). African migration: Diversity and changes. In C. Beauchemin (Ed.), Migration between Africa and Europe (pp. 35-80). New York: Springer Berlin Heidelberg.

Sigona, N. (2012). 'I have too much baggage': The impacts of legal status on the social worlds of irregular migrants. Social Anthropology, 20(1), 50-65.

Smith, J. P., \& Thomas, D. (2003). Remembrances of things past: Test-retest reliability of retrospective migration histories. Journal of the Royal Statistical Society. Series A (Statistics in Society), 166(1), 23-49.

Spire, A. (2005). Etrangers à la carte: L'administration de l'immigration en France (1945-1975). Paris: Grasset. 
Tall, S. M. (2008a). La Migration International Sénégalaise: Des Recrutements de Main-d'oeuvre Aux Pirogues. In M.-C. Diop (Ed.), Le Sénégal Des Migrations: Mobilités, Identités Et Sociétés, Hommes et sociétés (pp. 37-67). Paris: Karthala.

Toma, S. (2012). Ties that bind? Networks and gender in international migration. D.Phil. thesis, Nuffield College, University of Oxford, Oxford.

Triandafyllidou, A. (2009). CLANDESTINO project final report. Hellenic Foundation for European and Foreign Policy.

Triandafyllidou, A. (2010a). Irregular migration in Europe in the 21st Century. In A. Triandafyllidou (Ed.), Irregular Migration in Europe: Myths and Realities (pp. 1-21). Surrey: Ashgate Publishing, Ltd.

U.S. Census Bureau, Demographic Internet Staff. (2018). International programs, international data base. Retrieved March 31, 2018 https://www.census.gov/data-tools/demo/idb/region. php? $=\% 20$ Results $\% 20 \& \mathrm{~T}=13 \& \mathrm{~A}=$ aggregate $\& \mathrm{RT}=0 \& \mathrm{Y}=2018 \& \mathrm{R}=110 \& \mathrm{C}=$

Van Meeteren, M. (2012). Transnational activities and aspirations of irregular migrants in Belgium and the Netherlands. Global Networks, 12(3), 314-332.

van Nieuwenhuyze, I. (2008). Getting by in Europe's urban labour markets: Senegambian migrants' strategies for survival, Documentation and Mobility. Amsterdam: Amsterdam University Press.

Vickstrom, E. (2014). Pathways into irregular status among Senegalese migrants in Europe. International Migration Review, 48(4), 1062-1099.

Vogel, D., Kovacheva, V., \& Prescott, H. (2011). The size of the irregular migrant population in the European union - Counting the uncountable? International Migration, 49(5), 78-96.

Willems, R. (2008). Les 'Fous de Mer': Migrants Sénégalais Aux Îles Canaries. In M.-C. Diop (Ed.), Le Sénégal Des Migrations: Mobilités, Identités Et Sociétés, Hommes et sociétés (pp. 277-303). Paris: Karthala.

World Bank Group. (2016). Migration and remittances factbook 2016 (3rd ed.). Washington, DC: World Bank.

World Bank Group. (2017). Annual remittances data, inflows. Washington, D.C.: World Bank.

Xenogiani, T., Organisation for Economic Co-operation and Development, \& Agence française de développement. (Eds.). (2015). Connecting with emigrants: A global profile of diasporas, 2015. Paris: OECD.

Open Access This chapter is licensed under the terms of the Creative Commons Attribution 4.0 International License (http://creativecommons.org/licenses/by/4.0/), which permits use, sharing, adaptation, distribution and reproduction in any medium or format, as long as you give appropriate credit to the original author(s) and the source, provide a link to the Creative Commons licence and indicate if changes were made.

The images or other third party material in this chapter are included in the chapter's Creative Commons licence, unless indicated otherwise in a credit line to the material. If material is not included in the chapter's Creative Commons licence and your intended use is not permitted by statutory regulation or exceeds the permitted use, you will need to obtain permission directly from the copyright holder.

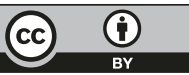




\section{Chapter 2 \\ Evolution of Immigration-Control Policies in France, Italy, and Spain}

\subsection{Policy Evolution in Multiple Contexts of Reception}

Senegalese migration is a useful case to study because Senegalese migrants are present in many different contexts of reception. They have long migrated to destinations within Africa, including neighboring countries such as the Gambia and Guinea and more-distant destinations such as Angola, the Democratic Republic of the Congo, and South Africa (Bredeloup 1993). While France was the main destination of Senegalese intercontinental emigration during most of the twentieth century, Senegalese migrants have since diversified their mobility to include many countries in Europe, North America, and Asia. Indeed, most Senegalese who travel abroad can recount stories of meeting other Senegalese in the markets of Nairobi, the cafés of Paris, the New York subway, or the streets of Bangkok.

This book takes advantage of part of this diversity of destinations to examine how variation in the socio-legal features of different contexts of reception creates complex trajectories of legal status for this intrepid group of migrants and will link different forms of legal status to the migrants' integration in the destination society and their ongoing participation in the development of their origin communities. While many different destinations could have been considered, this book and the data-collection project on which it is based chose to focus on France, Italy, and Spain. These three countries account for approximately $45 \%$ of all Senegalese migrants residing abroad (Beauchemin and González-Ferrer 2011). While they are all developed countries in the European Union, variations in their historical relationship with Senegal, the evolution of their immigration-control policies, their experiences in receiving immigrants, and their economies all create different configurations of legal status and possibilities of irregularity.

France is of obvious interest as the former colonial power in Senegal. Research has shown that links of language, transportation, and economic exchange forged during colonial times underlie many migration systems across the world (Kritz et al. 1992), and the migration patterns between Senegal and France are no exception to 
this rule (Garson 1992). No understanding of Senegalese migration would be complete without an accounting of Senegalese migration to France. In addition, the colonial relationship had important implications for the socio-legal parameters structuring the legal statuses of Senegalese migrants in France in the postindependence period. During the colonial era, Senegalese born in the so-called quatre communes of St. Louis, Gorée, Rufisque, and Dakar had a form of French citizenship, which Senegalese deputies to the French Assembly in the early twentieth century sought to reinforce via military service during the two World Wars. This "blood debt" later served as a pillar in the fight for secure legal status for Senegalese sans papiers in France (Coquery-Vidrovitch 2001; Mann 2003).

The colonial relationship also directly structured post-independence immigrationcontrol measures in France. The former colonial power sought to defend the vestiges of colonial privileges of free entry and establishment in Senegal for its own citizens, and thus created a preferential bilateral immigration-control regime with Senegal that facilitated the entry and eventual settlement of Senegalese in France. This preferential regime was largely at odds with the ordinance of 1945 that sought to recruit immigrants from culturally similar southern European countries for economic and demographic purposes (Spire 2005), which nonetheless established the framework for a restrictive immigration-control regime. While French policymakers immediately and constantly chipped away at the preferential regime between France and Senegal, it officially lasted until the early twenty-first century, and the evolution towards a closed and restrictive regime more in line with national immigration law was instrumental in encouraging both the settlement of formerly-mobile Senegalese migrants and their families in France and the exploration of new destinations such as Italy, Spain, Greece, and the United States.

The new destinations of Italy and Spain provide counterpoints to the experience of Senegalese migration to France. Both Italy and Spain have long histories as countries of emigration; indeed, both provided many migrants to France in the postWorld War II period. In contrast, these countries' experience receiving immigrants is much more recent. While France has been a country of immigration (in demographic if not cultural terms) since the late nineteenth century, Spain and Italy only started receiving migrants in the 1990s. As a result, Spanish and Italian apparatuses of immigration control are much more recent. Neither had any national-level immigration policy with the normative status of legislation until the 1990s, and the impetus for this legislation came from the European Union integration instead of any overriding internal concern with immigration; indeed, both countries still had low levels of immigration at the time of their respective laws (González-Enríquez 2009; Sciortino 1999).

Immigration-control policies in both southern European countries have since developed in a restrictive fashion, marked by an overriding concern with border control along Mediterranean coastlines. Indeed, these countries have reputations for being the clandestine port of entry for migrants from less-developed neighboring countries such as Morocco and Tunisia, and these North African countries have themselves transformed into transit points for migrants from sub-Saharan African countries (including Senegal) (de Haas 2007). Italy and Spain thus have a different 
history of immigration-control policies than France and face different immigrationcontrol challenges than their northern neighbor.

In addition, these two new destinations do not have any meaningful historical links with Senegal. Neither country had any colonial enterprises in Senegal or anywhere in West Africa, nor do they share cultural or linguistic links with Senegal. Unlike many other European countries of immigration, they also did not engage in post-war labor recruitment in former colonies. Research suggests that Senegalese migration to southern European countries started as a result of the confluence of immigration-control policies in the traditional and new destinations (Fall 2005; Kaag 2008; Tall 2008). France was tightening the preferential bilateral regime with Senegal in the 1980s and 1990s at the same time that Italy and Spain were starting to come to grips with increasing numbers of immigrants within their borders.

One of the first immigration-policy measures that the southern European countries pursued was regularization programs, which reportedly attracted Senegalese migrants from France who were finding it increasingly difficult to gain and maintain secure legal status (Fall 2005; Kaag 2008; Schoumaker et al. 2013; Tall 2008). Research also points to the role that the economies of these southern European countries played in attracting Senegalese migrants. Both countries have a morerobust informal sector than France, wherein migrants can find gainful employment without competing with natives or the need for legal authorization (GonzalezEnríquez and Triandafyllidou 2009; Reyneri 1998). Many Senegalese thus turned to informal entrepreneurial activities in northern Italy or informal agricultural labor in Spain as ways to accumulate the resources they were increasingly unable to find in France (Ebin 1992; di Friedberg 1993; Riccio 2001).

Immigration-control policies have thus played an important role in structuring the migration strategies and incorporation of Senegalese migrants in France, Italy, and Spain. This chapter will trace the evolution of those policies and the mechanisms of external and internal control (Brochmann 1999) they define (see Table 2.1 for the terms for visas, residence permits, and work permits in France, Italy, and Spain). It will examine the consequences policies and mechanisms of control have had for trajectories of legal status of Senegalese migrants, and in so doing will underline that the legal status that migrants possess is a "relational product" (Sciortino 2004): states create the legal parameters that define pathways to regular or irregular legal status.

Table 2.1 Terms for visa, residence permit, and work permit in France, Italy, and Spain

\begin{tabular}{l|l|l|l}
\hline Authorization & France & Italy & Spain \\
\hline Visa & Visa & Visto & Visado \\
\hline $\begin{array}{l}\text { Residence } \\
\text { permit }\end{array}$ & $\begin{array}{l}\text { Titre de séjour, carte de } \\
\text { séjour, carte de résident, } \\
\text { permis de résidence }\end{array}$ & $\begin{array}{l}\text { Permesso di soggiorno, } \\
\text { carta di soggiorno }\end{array}$ & $\begin{array}{l}\text { Permiso de residencia, } \\
\text { permiso de estancia }\end{array}$ \\
\hline Work permit & $\begin{array}{l}\text { Titre de travail, carte de } \\
\text { travail, autorisation de travail, } \\
\text { permis de travail }\end{array}$ & $\begin{array}{l}\text { Autorizzazione al } \\
\text { lavoro }\end{array}$ & $\begin{array}{l}\text { Autorización } \\
\text { administrativa para } \\
\text { trabajar }\end{array}$ \\
\hline
\end{tabular}




\subsection{France}

\subsubsection{Colonial "Assimilation" and Citizenship}

Senegalese migrants long benefitted from a special immigration-policy regime that traces its roots to the earliest days of the French colonial administration in Senegal. The French established their first permanent settlement in what is now Senegal on an uninhabited island in the mouth of the Senegal River in 1659. Originally set up as a trading post to take advantage of commercial opportunities along the river, Saint-Louis - named after King Louis XIV — eventually became the capital of the French colony of Senegal (Crowder 1967). A small community of French traders and mixed French-African "habitants" developed Saint-Louis into a commercial hub. The rights of the habitants as French citizens were recognized by the French revolutionary government in 1791, and a law in 1833 guaranteed the civil and political rights of all free-born or freed persons born in French colonies (CoqueryVidrovitch 2001). The revolution of 1848 further entrenched these rights by giving Senegal a seat in the French parliament and allowing Senegalese born in the quatre communes (four towns) of Saint-Louis, Gorée, Rufisque, and Dakar-called originaires (natives) — to vote as French citizens (Coquery-Vidrovitch 2001).

This extension of rights to Senegalese originaires was part of the French policy of colonial "assimilation." Crowder (1967) notes that "assimilation" can have many meanings when it comes to French colonial policy, but argues that its application in Senegal included political assimilation to France through elected representation in the French assembly; administrative assimilation through the creation of a conseil général and municipal councils for the governance of Senegal modeled on similar structures for departmental and municipal governance in France; and the extension of French educational facilities. Assimilation was also extended on the personal level by according originaires the status of French citizens. Originaires thus faced a much more lenient administration than residents of the rest of Senegal and other nations of Afrique Occidentale Française (AOF), who, as sujets (subjects), were subject to military rule, violence, cash taxes, and forced labor (Crowder 1967). Originaires were subject to French civil law unless they opted to remain under the traditional system of Islamic law with reference to civil disputes, matrimony, divorce, inheritance and land.

This bifurcation of French citizenship provoked a reaction on the part of the French, who felt that to be included in the French polity as a French citizen required a submission to French civil law and related institutions, such as monogamous marriage (Crowder 1967). As a result, French legislators and colonial administrators often attempted to redefine the boundaries of French citizenship and nationality in ways that would exclude the originaires from the full exercise of their rights (Coquery-Vidrovitch 2001). 


\subsubsection{Link Between Colonial-Era Policies and Migration}

The colonial-era policies depriving most Senegalese of political rights directly gave rise to migration. French colonization of Senegal was part of the partition of Africa by the major European powers. This partition drove expansion of capitalism, facilitating the extension of global markets and capital into African societies. Amin (1995) argues that this expansion allowed the colonizing countries to achieve the main capitalist goal of obtaining cheap export goods. He outlines the development of a system of colonial exploitation in various parts of the continent, including the extraction of raw materials (gold and diamond mining in South Africa, copper in Northern Rhodesia and Katanga) and the production of tropical agricultural products (palm oil in the Gold Coast, cacao in the Ivory Coast, and groundnuts in Senegambia).

A key component of these export systems' functioning was the creation and exploitation of labor from the "reserve" of indigenous Africans such as the French sujets. Through strategic political alliances, the subordination of traditional commercial relationships, monetary taxation of agricultural products, and forced labor, these colonial systems created a proletarianized labor force. Traditional society was thus transformed, Amin argues, into a "purveyor of temporary or permanent migrants on a vast scale" (1995: 33).

In colonial Senegal, the policies that created the statuses of "originaire" and "sujet" also undergirded the system of forced labor and taxation. Findley et al. (1995) argue that the colonial system disrupted the traditional agricultural economy of the Senegal River valley by instituting a head tax that induced peasants- the "sujets" of the French colonial legal system-to work in the groundnut and cotton plantations. Paying the monetary tax meant selling animals or portions of the harvest or seasonally migrating to the coastal colonial plantations to earn the money for the tax by selling labor. The French colonial regime also resorted to forced laborthe "navetanat" - to ensure a supply of labor on the groundnut plantations of the Sine-Saloum. The French colonial system in Senegal thus accomplished its goals of integrating the region into a monetized market economy and producing a surplus for export. The introduction of cash crops, the development of rail lines, and the investment in coastal cities all further eroded the pre-existing peasant modes of social and economic organization and contributed to a growing pool of potential emigrants. Furthermore, the internal mobility induced by the navetanat would eventually translate into international migration towards France (Findley et al. 1995).

While the status of sujet directly created internal and, eventually, international mobility among a portion of the Senegalese population, the status of originaire would also lay the foundations for future migration towards France. Blaise Diagne, who served as the first African deputy from Senegal to the French assembly from 1914 to 1937, attempted to reinforce the eroded political rights of originaires during World War I. He shepherded a series of laws through the French assembly that allowed Senegalese soldiers, who had heretofore served in the French military in 
segregated units called the tirailleurs sénégalais, to serve in regular units alongside French soldiers. The laws also stipulated that all natives of the quatre communes and their descendants would be French citizens subject to mandatory military service (Coquery-Vidrovitch 2001).

Senegalese and other natives of French West Africa fulfilled this obligation by serving as shock troops in World War I and fighting with General de Gaulle's forces in North Africa and Italy in World War II; West African troops even fought in French conflicts in Indochina and Algeria following World War II (Mann 2003). Following the wars, many soldiers from Senegal and other African territories enlisted in the French merchant marine and settled clandestinely in port cities such as Bordeaux, Toulon, Marseille, Le Havre, and Dunkerque (Manchuelle 1997). Although a boon for navigation companies looking for low-skill workers on boats and docks, the presence of these Africans incited public concern about security and public order (Fall 2005).

Despite this "blood debt" incurred by France, the French policy of assimilation existed mostly as an imaginary ideal, as colonial administrators consistently made attempts to limit claims to French citizenship and reinforce African inferiority (Coquery-Vidrovitch 2001; Crowder 1967). Despite these efforts to limit the ability of Senegalese to access the full rights French citizenship while burdening them with some of the onerous responsibilities, the precedent of political and personal assimilation created a special status for Senegalese that the French would continue to acknowledge in the preferential regime that followed independence in 1960 and that would directly create the conditions for migration to France.

\subsubsection{Post-War Reconstruction and the Importation of Foreign Labor}

Senegalese migration to France began in earnest following World War II as demand for unskilled foreign labor increased during the French economic boom of the 1950s and 1960s. France was one of the countries that turned to labor recruitment and importation to meet the challenges of post-war rebuilding in the context of labor shortages. Although the vast majority of imported laborers came from southern Europe, many also came from France's African colonies. Employers recruited workers in the rural Senegal River valley to work in flexible and low-skill jobs in the auto, textile, and hotel industries (Fall 2005). A system called noria ensured that circularity was the norm: Senegalese workers stayed in France for a number of years before returning home to send a family member to take their places (Tall 2008). Most migrants were primarily interested not in settling in France but in sending funds to their families in Senegal (Fall 2005). This voluntary separation from the host society found its residential complement in the foyers de travailleurs migrants, lodging provided by employers or municipalities that ensured that migrants were kept in close proximity to each other but separated from French society. 


\section{The General Regime of the Ordinance of 1945}

While Senegalese migrants were not initially subject to general immigration policy in postwar France, this so-called "general regime" provided the framework for the general evolution over more than 50 years of the bilateral accords providing juridical context for Senegalese migrants' legal status. The main pillar of postwar French immigration policy was the Ordonnance $n^{\circ} .45-2658 d u 2$ Novembre 1945, relative à l'entrée et au séjour des étrangers en France. This ordinance organized labor migration under the auspices of the Office national de l'immigration (ONI) (see Table 2.2 at the end of Sect. 2.2 for a synthesis of the evolution of immigration policy in France). Employers wishing to hire foreign labor were formally required to submit a request to ONI, which would fill the post with a qualified foreigner. The ordonnance further stipulated that foreigners entering for work needed to do so under cover of a visa and with a government-approved work contract. Upon arrival, migrants needed to apply for a permis de résidence (residence permit) from the Ministry of the Interior and a permis de travail (work permit) from the Ministry of Labor. There were many kinds of residence permits for different types of stay for more than 3 months, but obtaining a residence permit for the purposes of a salaried activity required the presentation of an official work contract. After obtaining a temporary authorization to stay in France, the migrant would then receive a work permit (Spire 2005).

In reality, decisions on the granting of residence and work permits were made by autonomous bureaucrats and were often not coordinated between Ministries, leading to permits of different lengths and the possibility of irregularity in either legal domain of work or residence (Spire 2005). The 1945 ordinance provided the foundations of immigration in policy in France through the end of the twentieth century, and its text was not officially modified until the 1980s. Most changes in immigration policy prior to those modifications thus occurred in administrative circulars issued by various ministries, a method chosen for its flexibility and lack of oversight in representative political bodies (although the Conseil d'Etat could, and occasionally did, weigh in on the constitutionality of these measures).

\section{Decolonization and the Creation of a Preferential Regime}

Senegalese were not initially subject to the general regime following the postwar reorganization of the French colonial system. This system, with its distinction between originaire and sujet, existed until 1946, when, in the aftermath of World War II, France promulgated a new constitution. At this point, all residents of French colonial territories and protectorates were granted French citizenship, which would, in theory, allow free circulation and establishment between the territories of the empire. In practice, colonial administrators did not allow colonial subjects to travel to the metropole, all the while encouraging intra-colony mobility via cash head taxes to assure a steady supply of labor for colonial cash crops, such as peanuts in Senegal (Amin 1972). 
Table 2.2 Synthesis of major immigration measures in France and consequences for migrant irregularity

\begin{tabular}{|c|c|c|}
\hline Date & Name of law & Consequence for irregularity \\
\hline \multirow{3}{*}{$\begin{array}{l}\text { November } \\
2,1945\end{array}$} & \multirow{3}{*}{$\begin{array}{l}\text { Ordonnance } n^{\circ} .45-2658 \text { du } 2 \text { Novembre } 1945 \text {, } \\
\text { relative à l'entrée et au séjour des étrangers en } \\
\text { France }\end{array}$} & Organized labor migration \\
\hline & & $\begin{array}{l}\text { Foreigners entering for work } \\
\text { needed to do so under cover } \\
\text { of a visa and with a } \\
\text { government-approved work } \\
\text { contract }\end{array}$ \\
\hline & & $\begin{array}{l}\text { Residence permit conditional } \\
\text { on presentation of work } \\
\text { contract }\end{array}$ \\
\hline \multirow[t]{2}{*}{$\begin{array}{l}\text { October } \\
13,1946\end{array}$} & \multirow[t]{2}{*}{ Constitution of the Fourth Republic } & $\begin{array}{l}\text { French citizenship granted to } \\
\text { all residents of French } \\
\text { colonial territories and } \\
\text { protectorates }\end{array}$ \\
\hline & & Creation of French Union \\
\hline \multirow[t]{2}{*}{$\begin{array}{l}\text { October 4, } \\
1958\end{array}$} & \multirow[t]{2}{*}{ Constitution of the Fifth Republic } & $\begin{array}{l}\text { Creation of the French } \\
\text { Community }\end{array}$ \\
\hline & & Independence of Guinea \\
\hline $\begin{array}{l}\text { April 18, } \\
1956\end{array}$ & $\begin{array}{l}\text { Circulaire du Ministère du Travail et des Affaires } \\
\text { Sociales }\end{array}$ & $\begin{array}{l}\text { Permitted post-arrival } \\
\text { regularization of workers }\end{array}$ \\
\hline $\begin{array}{l}\text { July 19, } \\
1960\end{array}$ & Convention d'établissement & $\begin{array}{l}\text { Senegalese free to enter, } \\
\text { reside, and work in France }\end{array}$ \\
\hline \multirow[t]{2}{*}{$\begin{array}{l}\text { January 21, } \\
1964\end{array}$} & \multirow[t]{2}{*}{ Bilateral treaty } & $\begin{array}{l}\text { Senegalese needed only an } \\
\text { identity card and proof of } \\
\text { vaccinations to enter France }\end{array}$ \\
\hline & & $\begin{array}{l}\text { Formal work was subject to } \\
\text { an employment contract } \\
\text { approved by the Ministry of } \\
\text { Labor and a pre-departure } \\
\text { medical exam }\end{array}$ \\
\hline $\begin{array}{l}\text { August 21, } \\
1967\end{array}$ & Ordonnance no 67-707 & $\begin{array}{l}\text { Reinforcement of medical } \\
\text { control for work }\end{array}$ \\
\hline $\begin{array}{l}\text { April 29, } \\
1968\end{array}$ & Décret d'application 68-399 & $\begin{array}{l}\text { Reinforcement of medical } \\
\text { control for work }\end{array}$ \\
\hline $\begin{array}{l}\text { July } 29 \text {, } \\
1968\end{array}$ & Circulaire du ministère des Affaires sociales & $\begin{array}{l}\text { Post-arrival regularizations of } \\
\text { workers scaled back }\end{array}$ \\
\hline $\begin{array}{l}\text { February } \\
25,1970\end{array}$ & $\begin{array}{l}\text { Note du } 25 \text { février } 1970 \text { de la Direction centrale } \\
\text { des Renseignements généraux consacrée au " } \\
\text { renforcement du contrôle des ressortissants } \\
\text { africains se présentant en qualité de touriste » }\end{array}$ & $\begin{array}{l}\text { Africans entering as tourists } \\
\text { integrrogated at border and } \\
\text { issued identity document }\end{array}$ \\
\hline \multirow{2}{*}{$\begin{array}{l}\text { January 24, } \\
1972\end{array}$} & \multirow[t]{2}{*}{ Circulaire Marcellin-Fontanet } & Limited regularizations \\
\hline & & $\begin{array}{l}\text { Combined residence/work } \\
\text { permit }\end{array}$ \\
\hline $\begin{array}{l}\text { March 28, } \\
1974\end{array}$ & Bilateral treaty & $\begin{array}{l}\text { Required residence permit } \\
\text { for stays greater than } \\
3 \text { months }\end{array}$ \\
\hline
\end{tabular}


Table 2.2 (continued)

\begin{tabular}{|c|c|c|}
\hline Date & Name of law & Consequence for irregularity \\
\hline $\begin{array}{l}\text { July 3, } \\
1974\end{array}$ & Decision by the Council of Ministers & $\begin{array}{l}\text { Suspension of labor } \\
\text { immigration (with } \\
\text { administrative circulars } \\
\text { following on July 5) }\end{array}$ \\
\hline $\begin{array}{l}\text { November } \\
30,1974\end{array}$ & $\begin{array}{l}\text { Circulaire n. 74-628, en date du } 30 \text { novembre 1974, } \\
\text { du Ministre d'Etat, Ministre de l'Intérieur, et la } \\
\text { circulaire n. 21-74, en date du } 30 \text { novembre 1974, } \\
\text { du Secrétaire d'Etat auprès du Ministre du Travail } \\
\text { relatives aux conditions de séjour et d'emploi des } \\
\text { ressortissants des pays d'Afrique au Sud du Sahara } \\
\text { autrefois sous administration française }\end{array}$ & $\begin{array}{l}\text { Required residence permit } \\
\text { for all nationals of sub- } \\
\text { Saharan African states } \\
\text { formerly under French } \\
\text { administration }\end{array}$ \\
\hline \multirow[t]{3}{*}{$\begin{array}{l}\text { January 1, } \\
1980\end{array}$} & \multirow[t]{3}{*}{ Loi Bonnet } & $\begin{array}{l}\text { Tightened entry requirements } \\
\text { by requiring repatriation } \\
\text { guarantees }\end{array}$ \\
\hline & & $\begin{array}{l}\text { Declared the entry or } \\
\text { residence of "illegal" } \\
\text { migrants to be a threat to } \\
\text { public order }\end{array}$ \\
\hline & & $\begin{array}{l}\text { Facilitated expulsions of } \\
\text { undocumented migrants }\end{array}$ \\
\hline $\begin{array}{l}\text { February 1, } \\
1981\end{array}$ & Loi Peyrefitte & $\begin{array}{l}\text { Allowed preventative identity } \\
\text { checks of suspected } \\
\text { undocumented migrants }\end{array}$ \\
\hline \multirow[t]{3}{*}{$\begin{array}{l}\text { October } \\
29,1981\end{array}$} & \multirow[t]{3}{*}{$\begin{array}{l}\text { Loi } n^{\circ} 81-973 \text { du } 29 \text { octobre } 1981 \text { relative aux } \\
\text { conditions d'entrée et de séjour des étrangers en } \\
\text { France }\end{array}$} & $\begin{array}{l}\text { Eliminated provisions of the } \\
\text { loi Bonnet allowing the } \\
\text { expulsion of minors and } \\
\text { parents of French children }\end{array}$ \\
\hline & & Return incentives abolished \\
\hline & & Regularization program \\
\hline \multirow[t]{2}{*}{$\begin{array}{l}\text { July } 17 \\
1984\end{array}$} & \multirow[t]{2}{*}{ Loi Dufoix } & $\begin{array}{l}\text { Formalized single residence/ } \\
\text { work permit }\end{array}$ \\
\hline & & $\begin{array}{l}\text { Introduced } 10 \text {-year } \\
\text { permanent residence card } \\
\text { with automatic renewal }\end{array}$ \\
\hline \multirow[t]{2}{*}{$\begin{array}{l}\text { September } \\
9,1986\end{array}$} & \multirow{2}{*}{$\begin{array}{l}\text { Loi Pasqua (I): loi } n^{\circ} 86-1025 \text { du } 9 \text { septembre } 1986 \\
\text { relative aux conditions d'entrée et de séjour des } \\
\text { étrangers en France }\end{array}$} & $\begin{array}{l}\text { Facilitated expulsion } \\
\text { procedures }\end{array}$ \\
\hline & & $\begin{array}{l}\text { Restricted access to 10-year } \\
\text { permit }\end{array}$ \\
\hline $\begin{array}{l}\text { September } \\
16,1986\end{array}$ & $\begin{array}{l}\text { Avis relatif à la suspension de certains } \\
\text { engagements internationaux portant dispense de } \\
\text { l'obligation du visa pour l'entrée en France }\end{array}$ & $\begin{array}{l}\text { Suspended the clauses of } \\
\text { bilateral treaties exempting } \\
\text { Senegalese and other } \\
\text { sub-Saharan Africans from } \\
\text { visas for entry to France }\end{array}$ \\
\hline $\begin{array}{l}\text { August 2, } \\
1989\end{array}$ & Loi Joxe & $\begin{array}{l}\text { Eased some of the restrictive } \\
\text { measures of Pasqua law }\end{array}$ \\
\hline
\end{tabular}


Table 2.2 (continued)

\begin{tabular}{|c|c|c|}
\hline Date & Name of law & Consequence for irregularity \\
\hline \multirow[t]{4}{*}{$\begin{array}{l}\text { August 1, } \\
1995\end{array}$} & \multirow[t]{4}{*}{ Bilateral treaty } & $\begin{array}{l}\text { Visas and proof of means/ } \\
\text { return trip required for entry } \\
\text { of Senegalese }\end{array}$ \\
\hline & & \begin{tabular}{|l|}
$\begin{array}{l}\text { Long-stay visa required for } \\
\text { stays of over } 3 \text { months }\end{array}$ \\
\end{tabular} \\
\hline & & $\begin{array}{l}\text { Approved work contract and } \\
\text { long-stay visa required for } \\
\text { entry for employment }\end{array}$ \\
\hline & & $\begin{array}{l}\text { Required a residence permit } \\
\text { for all stays in France } \\
\text { exceeding } 3 \text { months }\end{array}$ \\
\hline \multirow[t]{7}{*}{$\begin{array}{l}\text { August 24, } \\
1993\end{array}$} & \multirow[t]{7}{*}{ Loi Pasqua (II) } & $\begin{array}{l}\text { Made acquisition of French } \\
\text { citizenship more difficult for } \\
\text { children born in France }\end{array}$ \\
\hline & & $\begin{array}{l}\text { Facilitated the expulsion of } \\
\text { undocumented foreigners }\end{array}$ \\
\hline & & $\begin{array}{l}\text { Increased waiting time to } \\
2 \text { years for family } \\
\text { reunification }\end{array}$ \\
\hline & & $\begin{array}{l}\text { Prohibited the regularization } \\
\text { of undocumented migrants } \\
\text { who married a French citizen }\end{array}$ \\
\hline & & $\begin{array}{l}\text { Made the issuance of } \\
\text { residence permits dependent } \\
\text { on the regularity of entry and } \\
\text { prior stay }\end{array}$ \\
\hline & & $\begin{array}{l}\text { Denied re-entry for } 1 \text { year for } \\
\text { expelled foreigners }\end{array}$ \\
\hline & & $\begin{array}{l}\text { Created category of " } n i \\
\text { régularisable ni expulsable" }\end{array}$ \\
\hline \multirow[t]{2}{*}{$\begin{array}{l}\text { April 24, } \\
1997\end{array}$} & \multirow[t]{2}{*}{ Loi Debré } & $\begin{array}{l}\text { Allowed regularization of } \\
\text { "ni...ni" irregular migrants }\end{array}$ \\
\hline & & $\begin{array}{l}\text { Increased the state's } \\
\text { surveillance power of } \\
\text { suspected irregular migrants }\end{array}$ \\
\hline $\begin{array}{l}\text { June 24, } \\
1997\end{array}$ & Circulaire du ministère de l'Intérieur & $\begin{array}{l}\text { Case-by-case regularizations } \\
\text { with provisions for the } \\
\text { adjustment of status of } \\
\text { spouses with irregular status } \\
\text { and children of migrants with } \\
\text { irregular status }\end{array}$ \\
\hline $\begin{array}{l}\text { March 16, } \\
1998\end{array}$ & $\begin{array}{l}\text { Loi Guigou: Loi n } 98-170 \text { du } 16 \text { mars } 1998 \\
\text { relative à la nationalité }\end{array}$ & $\begin{array}{l}\text { Reinstated limited jus soli } \\
\text { citizenship provisions }\end{array}$ \\
\hline
\end{tabular}


Table 2.2 (continued)

\begin{tabular}{|c|c|c|}
\hline Date & Name of law & Consequence for irregularity \\
\hline \multirow[t]{2}{*}{$\begin{array}{l}\text { May 11, } \\
1998\end{array}$} & \multirow[t]{2}{*}{ Loi Chevènement/RESEDA } & $\begin{array}{l}\text { Reformed system of } \\
\text { residence permits to reinforce } \\
\text { rights of migrant families }\end{array}$ \\
\hline & & $\begin{array}{l}\text { Enacted "on the fly" } \\
\text { regularizations for those } \\
\text { proving } 10 \text { years of residence } \\
\text { in France }\end{array}$ \\
\hline \multirow{5}{*}{$\begin{array}{l}\text { November } \\
26,2003\end{array}$} & \multirow{5}{*}{$\begin{array}{l}\text { Loi Sarkozy: Loi } n^{\circ} 2003-1119 \text { du } 26 \text { novembre } \\
2003 \text { relative à la maîtrise de l'immigration, au } \\
\text { séjour des étrangers en France et à la nationalité }\end{array}$} & Eased the expulsion process \\
\hline & & $\begin{array}{l}\text { Increased the period of } \\
\text { detention for irregular } \\
\text { migrants to } 32 \text { days }\end{array}$ \\
\hline & & $\begin{array}{l}\text { Reinstated strict controls on } \\
\text { marriage with a foreign } \\
\text { spouse }\end{array}$ \\
\hline & & $\begin{array}{l}\text { Increased waiting time for } \\
\text { permanent residence permit }\end{array}$ \\
\hline & & $\begin{array}{l}\text { Made issuance of permanent } \\
\text { and family-reunification } \\
\text { permits contingent on } \\
\text { integration }\end{array}$ \\
\hline $\begin{array}{l}\text { November } \\
24,2004\end{array}$ & $\begin{array}{l}\text { Code de l'entrée et du séjour des étrangers et du } \\
\text { droit d'asile (CESEDA) }\end{array}$ & $\begin{array}{l}\text { Consolidated immigration } \\
\text { law }\end{array}$ \\
\hline \multirow[t]{3}{*}{$\begin{array}{l}\text { July } 24, \\
2006\end{array}$} & \multirow[t]{3}{*}{$\begin{array}{l}\text { Loi Sarkozy (II): Loi } n^{\circ} 2006-911 \text { du } 24 \text { juillet } \\
2006 \text { relative à l'immigration et à l'intégration }\end{array}$} & $\begin{array}{l}\text { Allowed for some kinds of } \\
\text { immigration choisie } \\
\text { (high-skilled workers) }\end{array}$ \\
\hline & & $\begin{array}{l}\text { Repealed provision for } \\
\text { regularization of long-term } \\
\text { residents }\end{array}$ \\
\hline & & $\begin{array}{l}\text { Required contrat d'accueil et } \\
\text { d'intégration for family } \\
\text { reunification and permanent } \\
\text { residence }\end{array}$ \\
\hline $\begin{array}{l}\text { September } \\
23,2006\end{array}$ & $\begin{array}{l}\text { Accord entre le Gouvernement de la République } \\
\text { française et le Gouvernement de la République du } \\
\text { Sénégal relatif à la gestion concertée des flux } \\
\text { migratoires }\end{array}$ & $\begin{array}{l}\text { Allowed issuance of } \\
\text { residence permits for } \\
\text { Senegalese with a job offer } \\
\text { (even those irregularly } \\
\text { resident in France) in any of } \\
10 \text { listed professions }\end{array}$ \\
\hline
\end{tabular}

As Senegalese and other African subjects were still part of the French empire and were not considered foreigners, the ordonnance of 1945 thus would not have applied to them if they had sought to work in France. In reality, the colonial system still prevented circulation between the colonies and the metropole, so sub-Saharan African workers were not, at this point, considered as a viable source of metropolitan labor even though they had been considered as a viable source of military manpower during the two World Wars. 
During the post-war era, African political elites were debating the place of their societies in the French colonial system: while some leaders favored ongoing federation with the colonial power and the assimilation to the French polity and nation that it implied, others favored the independence of the colonies as sovereign nationstates. France decided to put the issue to a vote in 1958, when it proposed a new constitution that defined a new Communauté française. France organized a referendum by which colonial territories were free to accept the constitution, and remain within the Communauté, or reject it and become an independent nation-state. Guinea, under the leadership of the trade unionist Sékou Touré, voted resoundingly to reject the constitution and became independent in 1958. Senegal and the other colonial territories remained in the Communauté, but the inexorable momentum was towards independence, which Senegal achieved in 1960, first as a federation with neighboring Mali and subsequently as a fully independent nation-state in 1962.

\subsubsection{The 1960s: The Special Regime of the Bilateral Accord and Widespread Irregularity}

\section{Senegalese Independence, the Preferential Regime, and "Immigration Sauvage"}

France did not block its African territories from becoming independent but was concerned about protecting its colonial interests, giving rise to a series of bilateral treaties with the newly independent countries that defined the legal framework for circulation between and residence in the respective countries. One of the most important treaties was the "Convention d'établissement," which stated that French nationals resident in Senegal had the same rights as Senegalese nationals, and vice versa. This reciprocity, called "assimilation au national", notably guaranteed bilateral freedom of entry and residence and free exercise of economic activities (Dedieu 2011). While in some ways these provisions allowed for the continuation of French colonial citizenship for Senegalese nationals, the motive for this treaty was to protect the rights of French citizens in Senegal (Donovon 1988; Marot 1995). The practice of "assimilation au national" was enacted in a bilateral treaty signed by France and Senegal in 1964 that allowed for free circulation between the two countries and free establishment and exercise of professions for expatriates residing in the foreign country. Senegalese needed only an identity card and proof of vaccinations to enter France, while formal work was subject to an employment contract approved by the Ministry of Labor and a medical exam at the French consulate in Senegal.

While the provisions of this treaty seem remarkably open, at the time it was seen as restrictive: the independence of Senegal and other African colonies had provoked what was seen as an "immigration sauvage" to the metropole, and the French authorities saw the requirement of identity documents, vaccination cards, and work contracts as an effective way to stem this flow (Bergues 1973; Diop 1993). Even 
Senegalese authorities criticized this new flow of emigrants, and imposed an exit visa for Senegalese wishing to travel to France (Kane 2011). Thus, while Senegalese did not need a visa to enter France and did not need a residence permit to reside there, the requirement of an exit visa and of identity documents created the framework for a kind of irregular status. Senegalese without identity documents would often enlist as crew or stow away on France-bound ships and would then enter France clandestinely when the ship docked at Bordeaux or Marseille. These migrants could be considered to have entered irregularly even though no visa was required (Bergues 1973). Senegalese migrants with identity documents would also circumvent the exit-visa requirement by traveling to neighboring African countries to other European countries before traveling to France (Bergues 1973). Senegalese and other former African subjects thus faced legal configurations that created the conditions for irregularity even during this early "preferential" regime (Lochak 1997).

There was increasing concern throughout the 1960s in France about the continued "immigration sauvage" of Senegalese and other sub-Saharan Africans despite their limited presence (Tapinos 1965 estimates the total "very low" sub-Saharan population at 35,000). Reports to the Conseil économique et social in 1964 and 1968 highlighted the deplorable conditions under which many of these migrants lived, and articles in the popular press "discovered" these migrants and likened their situation to modern slavery (Diop 1993). A particular concern was the high rate of tuberculosis among sub-Saharan Africans in France; a series of circulars in 1968 and 1969 thus reinforced the requirements of medical examinations prior to entry for work (Bergues 1973).

In addition to concerns about the health and living conditions of these migrants, there was a growing realization that many of the limited number of Africans residing in France arrived as tourists and subsequently found work and regularized their status after arrival. While the bilateral treaties only allowed Senegalese to enter France for work under cover of a formal work contract, the treaties did not allow Senegalese to be refused employment once in France. The treaties also did not require Senegalese to have a carte de séjour or a permis de travail. As a result, many Senegalese entered France on their identity cards (or those of others if they did not have their own) and simply looked for work once in France. The Ministry of the Interior thus sought to impose the obligation of a carte de séjour on Senegalese and other Africans who were subject to bilateral accords that exempted them from the general requirement to possess such an authorization (Spire 2005).

Unable to convince the Ministry of Foreign Affairs to push for the revision of the treaties, the Ministry of the Interior thus published a "note" in February 1970 instructing border-control agents to interrogate Africans arriving at the border as to their motives for stay and their means of return to their home countries. If admitted, the African "tourist" would then be issued a "notice individuelle pour touriste étranger" (individual notice for foreign tourist) with the tourist's civil status and expected length of stay in France. This document had to be presented to police during identity checks, and formed that juridical basis for expulsion of the perceived increasing number of "clandestine" African migrants (Spire 2005). This immigrationcontrol measure, of questionable legal validity because of the exemption of 
Senegalese from general immigration requirements, thus provided French authorities with a "back door" to combat this unwanted flow and transform migrants who were "regular" from the point of view of the treaties governing their status into "clandestine" migrants with "irregular" status. The French state thus took concrete steps in the 1960s to transform a legal flow of migrants into an irregular one in the pursuit of increased control.

\section{The General Regime: Post-facto Regularization as the Norm}

At the same time that pressure was mounting to submit Senegalese and other former subjects from sub-Saharan Africa under stricter control, the general immigrationcontrol regime started to come under criticism. During the post-war period-known in France as les trente glorieuses-irregularity among immigrants was widespread. From the end of World War II to the 1970s, illegal immigration was the de facto migration policy advocated by the French government. Throughout the 1950s and 1960s, the ONI had the official monopoly on the introduction of foreign labor into France. In reality, however, direct hire of foreigners by employers and subsequent regularizations of status were the norm. This arrangement between employers and the state has its legal basis in a circular issued by the Ministry of Labor on April 18, 1956, which put "regular" immigration organized by ONI and post-arrival regularization procedures on the same plane, and encouraged regularization of workers in sectors where there were labor shortages (Spire 2005).

This leniency in the introduction of foreign labor was related to an economic recovery in 1955-1956 and the start of the war in Algeria, which drained native manpower from France and limited the ability of employers to recruit labor from North Africa. In the decade following the issuance of this circular, the vast majority of foreign workers in France underwent regularization after irregular arrival and irregular employment. Laubenthal (2007) reports that $80 \%$ of foreign workers in France at the end of the 1960s underwent this adjustment of status, and that the ONI's role was effectively reduced to conducting post-arrival regularizations. Economic conditions-growth and the demand for flexible labor-thus created political tolerance of irregular migration, and the legal framework was adapted to allow these employers to hire and adjust the status of these flexible workers. Furthermore, most of the beneficiaries of this ongoing regularization regime were Portuguese, Spanish, or Italian, and Spire (2005) argues that this legal mechanism was motivated, in part, by a desire to counterbalance the ability of racially distinct former colonial subjects from Africa to enter and work in France without the need for official authorization.

An economic slowdown in 1965 pushed French authorities to reconsider this "spontaneous" immigration system that escaped the boundaries of formal immigration law. Post-arrival regularizations, which had been the lifeblood of French labor recruitment, were scaled back by a circular issued on July 29, 1968 by the Ministry of Social Affairs. While in legal terms this circular only called for a stricter application of the laws already on the books (which did not allow for post-arrival 
regularizations), in practical terms it did start to impede regularizations, the rate of which dropped from 82\% in 1968 to $60.3 \%$ in 1971 (CERC-Association 1999). The fact that this measure did not completely prevent regularization was due to the fact that it continued to allow Portuguese nationals and workers in certain sectors (including domestic workers) to be regularized. It is reasonable to assume that many Senegalese migrants experienced spells of irregularity during this period given the tolerance and even encouragement of unauthorized entry by both the state and employers.

\section{The End of Regularization and the Suspension of Labor Immigration}

Further slowing of the economy and an increasing desire on the part of French authorities to control "irregular" migration-which was, in reality, produced by the administrative interpretation of the 1945 ordonnance-prompted additional restrictions on post-arrival regularizations in 1972. The Marcellin and Fontanet circulars, issued by the Ministries of Interior and Work, respectively, effectively limited regularizations by requiring employers requesting the regularization of a foreign employee to post an offer for the foreigner's job with the Agence national pour l'emploi (ANPE), allowing French nationals to apply for it (Spire 2005). These measures seem to have had their intended effect, as the regularization rate dropped below $60 \%$ in 1972 and 1973, although Portuguese were still exempt from these restrictions.

The 1972 circulars also undertook a major reform in the system of residence and work permits, which both reduced the ability of foreign workers to regularize their status after arrival and created new kinds of irregularity. The circulars envisaged a "guichet unique" where migrant workers would apply simultaneously for residence and work permits. These permits were to be issued for the same length of time, eliminating the possibility that migrants could have regular status in one legal domain and not the other. The circulars also subjected the issuance of a residence permit to the possession of a work permit: a foreigner applying for these authorizations filled out a single form and had to produce a work contract and a certificate of an offer of employment endorsed by the ANPE (Spire 2005). Workers without a formal work contract were unable to obtain authorization to work or reside in France and were ineligible for exceptional regularization procedures; these circulars, in attempting to create a system of stricter immigration control, thus transformed formerly regularizable workers into irregular migrants (Spire 2005).

\subsubsection{The 1970s: The "Closing" of the French Border and the Erosion of the Bilateral Accord}

Major changes to French immigration policy wrought by the economic crises in the 1970s would further erode the special status of Senegalese migrants in France granted by the independence-era bilateral accords. After almost three decades of 
economic growth and relative prosperity, the oil shock of 1973 sent the world and French economies into a tailspin. Even before this climactic event, unemployment had been increasing and there was growing restlessness about the increasing number of foreign workers in France and the relative ease with which they entered the country and subsequently found jobs and regularized their situations (Laubenthal 2007).

In addition, France saw an increasing influx of foreigners from its former colonies in North and West Africa, including Senegal. The economic situation in Senegal declined starting in the 1960s. A major drought started in 1969 while the world market for peanuts collapsed after the end of French price support; and the 1973 oil crisis combined with high population growth to reduce Senegal's economic prospects (Mezger Kveder 2012). Unlike the Spanish, Portuguese, and Italian immigrants of the early post-war period who were seen as having similar cultural values and were thus prized not only for labor purposes but also for demographic "repeopling," former colonial subjects such as those from Senegal were perceived as difficult to assimilate into the French polity and way of life (Spire 2005).

The French government responded to these economic and social pressures by unilaterally suspending labor immigration through a decision by the Council of Ministers on July 3, 1974. Administrative circulars "temporarily" put an end to the introduction of salaried workers on July 5 and to the introduction of applications for family reunification on July 9 of that year. The circulars officially activated the government's ability to refuse applications for cartes de séjour based on the national employment situation (CERC-Association 1999). The suspension of family reunification provisions, formalized in a decree issued on September 27, 1974, was rejected by the Conseil d'Etat and reunification procedures, under stricter lodging conditions, were officially reinstated by the government on April 29, 1976 (CERCAssociation 1999).

While the circulars contained exemptions to allow for the entry of foreign labor in sectors where the national labor supply was insufficient (Gokalp 1975), the "temporary" suspension of labor immigration became de facto permanent over the course of the 1970s, with recourse to rejections of applications for residence and work permits because of the national employment situation increasingly common (CERCAssociation 1999). Contemporaneous study of the impact of these measures indicated that they had been successful in reducing entries, but also in increasing the irregularly resident population (Gokalp 1975).

In addition, in an effort to prevent immigrant workers from entering and working in France, all categories of foreigners wishing to enter the country-students, refugees, reunified family members-faced suspicion of being "hidden workers" and thus underwent additional scrutiny from enhanced immigration-control systems (CERC-Association 1999). These administrative actions also actively created irregularity of status by denying residence and work authorizations, and the French state thus had to identify and deal with these irregular migrants by trying to repatriate or regularize them. 


\section{Establishment of the Carte de Séjour Requirements for Senegalese}

The decision to suspend labor immigration further eroded the bilateral regime that defined the legal framework of Senegalese migration to France. The stricter control on migrant labor enacted in the 1972 and 1974 circulars reflected an increasing emphasis on border surveillance and the control of labor flows, which had long been marginalized by postwar immigration policy's de facto tolerance of irregular immigration and post hoc regularization (Spire 2005). The ability of Senegalese and other sub-Saharan Africans formerly under colonial control to enter and reside in France without authorization clashed with this new emphasis on the "maittrise des flux" (immigration control) and so the Ministry of the Interior finally convinced the Ministry of Foreign Affairs to re-negotiate the treaties that created this preferential regime (Spire 2005). Senegal and France signed a re-negotiated bilateral accord on March 28, 1974 that required Senegalese staying in France for more than 3 months to "possess and produce upon demand" a titre de séjour (residence authorization) but did not require a visa for entering the country. Senegalese living in France as of January 1, 1974 were issued a renewable residence permit that would be valid for not less than 5 years.

While this bilateral accord was not ratified until December 19, 1975, the French Ministries of Labor and the Interior issued circulars on November 30, 1974 requiring all nationals of sub-Saharan African states formerly under French administration to be in possession of a titre de séjour from January 1, 1975 onwards. Senegalese and some other African nationals were not required to apply for a separate carte de travail, but the circulars specified that the issuance of the titre de séjour was contingent upon presentation of a government-approved work contract issued prior to the departure from the origin country. Family reunification was still allowed, but was conditional on a certificate of lodging and a medical exam of the family members (Gokalp 1975; Marot 1995; Viet 1998).

While the Interior and Labor circulars of 1974 respected some of the elements of the Franco-Senegalese treaty of 1974 (such as the issuance of a 5-year residence permit for Senegalese already residing in France, as opposed to a 3-year permit issued to other African nationals), they went beyond the scope of the accord by making a residence permit contingent on a work contract. The Conseil d'Etat canceled some of the measures in 1978, including the ability to reject applications based on the national employment situation (thus partially reaffirming the special status of former colonial subjects), but it reaffirmed the general principles that Senegalese and other former colonial subjects were required to have a titre de séjour and that this permit could be conditioned on having a formal work contract certified by the Ministry of Labor (Marot 1995).

The renegotiation of the bilateral accord and subsequent unilateral abrogation of the bilateral treaties previously on the books in 1974 thus moved the "preferential regime" for Senegalese much closer in line with the general regime. With labor immigration officially suspended, the work contract on which successful applications 
for a residence permit depended would be almost impossible to acquire, thus effectively limiting the ability of Senegalese to enter France for work. This requirement probably had only a small impact on the official flow of Senegalese workers to France, however, as their numbers were already limited by the difficulty, even prior to 1974, of acquiring a work contract (Bergues 1973).

The main impact of requiring a residence permit and making it conditional on a work contract would make it almost legally impossible for Senegalese who entered France as "tourists" to stay for more than 90 days. These modifications of the bilateral regime thus created new possibilities for irregular status for Senegalese migrants: those entering legally as "tourists" would become irregular by staying past 90 days, and those Senegalese already in France as of 1974 would inevitably become irregular after the expiration of their first residence permit if unable to present a formal work contract to accompany their application for renewal.

It is no coincidence that these modifications to the preferential regime occurred in 1974, a moment during which there was political and economic momentum for the closing of French borders to foreign workers. These modifications also drew on the innovations introduced by the Marcellin-Fontanet circulars of 1972, especially the concept of the "guichet unique," which created a single residence and work permit and made residence authorization conditional on a formal work contract. At the same time, Senegalese and other sub-Saharan Africans were required to interact with the French administration via an "office of foreigners with special status," often staffed by former colonial administrators with "expertise" in dealing with subSaharan Africans, thus indicating that the integration of these former subjects into the general regime was not yet complete (Spire 2005).

The rest of the 1970s saw the general immigration-control regime drift further towards policies of exclusion and surveillance. While the 1974 circulars had been effective at reducing immigration to France, they did not eliminate it completely, and those migrants that remained became more focused on settlement in France as the borders closed (Schain 2008). The French government thus decided in 1977 to suspend family reunification (reversed the following year by a decision of the Conseil d'Etat) and initiated policies to facilitate the "voluntary return" of migrants (Schain 2008).

Senegalese migration to France evolved as a result of these changes to French immigration policy in the 1970s. Restrictions on labor immigration encouraged settlement among formerly mobile Senegalese, and leading some single male migrants to bring wives and children via family reunification (although Beauchemin et al. 2013 suggest that Senegalese have been quite reluctant to reunify in Europe). Qualitative studies have also found visa overstaying among Senegalese to be prevalent since 1974 (Tall 2008). 


\subsubsection{The 1980s: Immigration Policy as a Political Football and Consensus in Border Security}

The alternation between right- and left-wing governments in the 1980s led immigration policy to experience multiple swings between restriction and liberalization but led to a convergence on the issue of border control that would eventually serve as the foundation for a complete abrogation of the special regime of the bilateral accords. The decade saw, for the first time, major revisions of the 1945 ordonnance governing the general immigration regime. The decade began with a re-entrenching of the exclusionary policies enacted in the 1974 circulars via the Bonnet law. Passed by a right-wing government in 1980, the law tightened entry requirements by requiring repatriation guarantees and declared the entry or residence of "illegal" migrants to be a threat to public order (Schain 2008). The law also made expulsions of undocumented migrants easier, even if they were minors or had family attachments (Schain 2008).

Further measures in the early 1980s targeted migrants resident in France as a threat to public order and laid the legal basis for their expulsion. The Peyrefitte law of 1981 increased the policing power of the state vis-à-vis migrants by allowing preventative identity checks of suspected undocumented migrants. A circular from the Ministry of Labor on June 10, 1980 encouraged the labor administration to invoke the national employment situation as a motive for refusing the renewal of work permits, which would make migrants ineligible for renewal of their residence permits; this motivation for refusal was even applied to those migrants who were still employed, effectively expelling them from France (CERC-Association 1999). Deportation became a primary tool of the French government for both combatting "clandestine" immigration and employment and making migrants' stays in France precarious (Miller 1994). As Senegalese were subject to requirements for residence permits conditional upon work authorization from 1974 onward, these restrictive measures undoubtedly affected them as well.

The arrival of the left-wing Mitterrand government to power in 1981 inaugurated an era during which immigration policy was a political football for alternating leftand right-wing governments. Between August and October 1981, a series of reforms sought to roll back some of the restrictive measures of previous years: incentives to return were abolished; the government eliminated the provisions of the Bonnet law allowing the expulsion of minors and parents of French children or children born or arrived in France before the age of 10; and a vast regularization program adjusted the statuses of 132,000 migrants (CERC-Association 1999). The Dufoix law of July 17, 1984 followed these liberalizing reforms with a complete revision of the system of residence permits, reducing their number to two.

The Dufoix law introduced a 10-year carte de résident, which granted work authorization and was automatically renewable; this permit thus removed the obligation of 
prior work authorization for settled immigrants and implicitly recognized the permanent nature of immigration to France (Weil 1995). The law also defined a temporary carte de séjour with a maximum validity of 1 year. Foreigners wishing to work would still need a prior work authorization, but a foreigner not wishing to work in France could be authorized to stay without working upon proof of adequate means of existence (CERC-Association 1999). The guichet unique of the 1972 Marcellin-Fontanet circulars was thus enshrined in legislation, abolishing the duality of residence and work permits while making the former dependent on the latter.

Despite these reforms, some of the previous government's restrictive measures were maintained, including preventative identity checks and the retention and forced expulsion of some migrants (CERC-Association 1999). Additional restrictive reforms were initiated under the right-wing "cohabitation" government led by Prime Minister Chirac from 1986 to 1988. The first Pasqua law of 1986 facilitated expulsion procedures and restricted access to 10-year permits (Schain 2008). The resumption of a left-wing parliamentary majority in 1988 led to the Joxe law of 1989 that eased some of the restrictive measures of Pasqua's law.

Regardless of the political and legislative jousting over immigration, there was an increasing convergence between the left and right on issues of border security: while opposed on issues of immigrant integration and security of residence, both sides seemed to find political utility in securing the frontier through increased external controls, rejection of asylum claims, and increased police control and occasional roundups of suspected undocumented immigrants (Schain 2008).

\subsubsection{Visa Requirements for Senegalese and the Re-negotiated Bilateral Accord of 1995}

\section{Unilateral Imposition of Visa Requirements in 1986}

The evolution across the political spectrum towards a system of hardline external controls led to fundamental changes to the bilateral immigration regime with Senegal. Against a backdrop of terrorist attacks in Paris, the French government unilaterally suspended, via a notice from the Ministry of Foreign Affairs on September 16, 1986, the clauses of bilateral treaties exempting Senegalese and other sub-Saharan Africans from visas for entry to France (Marot 1995). While this measure initially applied to Americans, Canadians, and EU nationals as well as nationals of former French colonies, the French government would subsequently exempt citizens of developed countries, thus creating a system of external controls for developing countries deemed to present a "migratory risk." This measure added external control to the Senegalese immigration-control system. Following the requirements that Senegalese possess residence and work permits in 1974, the 1986 abrogation of the treaty and requirement of visas moved the Senegalese immigration regime yet another step closer to integration with the general regime. 


\section{New Bilateral Accord}

The abrogation of the independence-era accord in 1986 and the establishment of entry visas for Senegalese opened the door to further alignment of the bilateral system with the general regime. While the Franco-Senegalese treaty of 1974 instituted requirements for residence permits, the unilateral imposition of visa requirements by the French government in 1986 was at odds with the existing accord. A new treaty was thus signed by France and Senegal on August 1, 1995 ${ }^{1}$ that codified the visa requirements of 1986. Senegalese wishing to enter France for a stay of less than 3 months had to apply for a visa and show both proof of means of existence during the stay and a return-trip ticket to Senegal. For stays longer than 3 months, Senegalese had to apply for a long séjour (long-stay) visa. If they wished to work upon arrival, the treaty required them to have an approved work contract prior to departure in addition to a long-stay visa.

This new system of visas for Senegalese mirrored the visa requirements of the Schengen system. An inter-ministerial committee decided on July 10, 1991 to promulgate as official policy the "control of migratory flows" (maîtrise des flux migratoires) in keeping with France's 1990 accession to the Schengen treaty and its stringent border-control requirements. These developments led to a new push to revise the bilateral treaties with African states. The Senegalese treaty required a residence permit for all stays in France exceeding 3 months. While the exact regulations governing granting of this permit were not specified, it is likely that they were subject to the prevailing legislation regarding residence permits (i.e., that they were conditioned on having a formal work contract or proof of means of existence). The only nod to the formerly privileged status of Senegalese was the provision for granting a 10-year titre de séjour after continued regular residence of 3 years as opposed to 5 years in the prevailing legislation; Senegalese were otherwise subject to provisions in line with the general immigration regime.

\subsubsection{The 1990s: Pasqua, Debré, and the Sans-Papiers Movement}

The 1990s brought both increased emigration pressure to Senegal and further alignment of the Senegalese immigration framework with general French policies. Senegal agreed to implement a series of structural adjustment programs (SAPs) in the 1980s and 1990s, which aggravated urban poverty and produced unsatisfactory macroeconomic outcomes (Mezger Kveder 2012). The Senegalese currency, the CFA franc, was devalued in 1994. Although this move restored some competitiveness to the Senegalese economy and improved monetary measures of poverty, survey results suggest that the majority of Senegalese perceived their economic

\footnotetext{
${ }^{1}$ Although signed in 1995, the treaty was not published in the Journal officiel de la République Française until March 12, 2002.
} 
well-being to have stagnated or deteriorated in the late 1990s (Mezger Kveder 2012). During this mostly negative economic evolution, Senegal became a net exporter of migrants.

French immigration policy in the 1990s further increased restrictions on Senegalese and other sub-Saharan African migrants via the Pasqua and Debré laws. The right-wing cohabitation government headed by Balladur in 1993 overtly proclaimed a goal of "immigration zéro" (Hollifield 1999), which was translated into legislation by the second Pasqua law. The goal of this law was to roll back procedural and social rights for immigrants in France and limit their ability to settle in the country (Hollifield 1999).

The law also created new forms of legal precarity for a number of categories of migrants: it made acquisition of French citizenship more difficult for children born in France, facilitated the expulsion of undocumented foreigners, increased waiting time to 2 years for family reunification, prohibited the regularization of undocumented migrants who married a French citizen, made the issuance of residence permits dependent on the regularity of entry and prior stay, and denied re-entry for 1 year for expelled foreigners (Hollifield 1999; Schain 2008; Wihtol de Wenden 2002). This law, in pursuing a zero-tolerance strategy on immigration, thus created new pathways into irregularity by making it more difficult to gain and maintain regular status.

The Pasqua law also created contradictory legal situations for many migrants in which they were "ni régularisable ni expulsable" (neither regularizable nor deportable). Such migrants were not eligible for renewal of status because of the restrictions in the Pasqua law, but also could not legally be deported, often because of other provisions in existing laws that protected migrants who had resided in France for a long time or those with "attachments" in France from being deported (Hollifield 1999). Of particular consequence for Senegalese and other African migrants were restrictions on accessing and renewing residence permits for polygamous families, which forced "secondary" spouses to choose either divorce and "décohabitation," remaining in a polygamous union and falling into irregular status, or returning to Africa (Alaux 2001).

Choosing to remain in a polygamous marriage would mean falling into the gray zone of being neither regularizable nor deportable for both secondary spouses and their husbands: they would not be eligible for renewal of residence permits, but they could not be deported since most had minor children who qualified their parents for protection. While not all Senegalese families were polygamous, the law certainly drew on public anxieties about African polygamy to restrict this family form, echoing the debate from the colonial administration in Senegal that saw polygamy as incompatible with French citizenship.

The contradictions inherent in the Pasqua law gave rise to the sans-papiers movement of 1996. This movement was made up of Senegalese and other West Africans, many of whom were neither regularizable nor deportable because of the Pasqua law. More than 300 migrants camped in two different churches in Paris between March and August 1996 to bring public attention to their legal plight (Marin 2006). They demanded that the government recognize the absurdity of their 
administrative situations and offer pathways to regular status. The occupation of the Saint-Bernard church ended dramatically with the French National Police in riot gear chopping down the wooden door and forcibly evacuating the sans-papiers, but not before garnering national attention that spurred 10,000 people to march in Paris in support of their cause in February 1997 (Marin 2006; Terray 2006).

The government, led by then-President Chirac, responded in April 1997 with another modification of the 1945 ordonnance. The Debré law, although it sought to resolve some of the "ni...ni" contradictions of the Pasqua law highlighted by the sans-papiers movement, actually contained provisions that would make it "impossible for most of the protesters to regularize their status" (Schain 2008: 54). While French-born minor children of irregular migrants and foreign spouses of French citizens with irregular status could neither receive an adjustment of status under the Pasqua law nor be deported because of their family attachments, the Debré law set the bar unrealistically high for regularization of these categories of migrants. "Foreign" children under the age of 16 would have to demonstrate 10 years of continuous residence in France before being granted a 1-year residence permit, and "foreign" spouses had to have been married for 2 years before being eligible for the same 1-year permit (Hollifield 1999; Schain 2008). The law thus prolonged the duration of irregularity for these "ni...ni" migrants with strong family links to France. The Debré law also increased the state's surveillance power of suspected irregular migrants: it allowed the confiscation of the passports of migrants in an irregular situation, the storage of fingerprints of foreigners applying for a residence permit, increased police power, and restricted judicial power in matters of retention of irregular migrants (Hollifield 1999).

Hollifield argues that one of the underlying intents of the Pasqua and Debré laws was to "devise a system for controlling entries by Africans" (1999: 83). The Pasqua law's targeting of polygamous families was clearly aimed at African migrants, and its hardening of the barriers to legal stay and acquisition of citizenship for children of irregular migrants demonstrated a desire to uproot entire families. Early versions of the Debré law required French citizens to report the presence of any foreigners hosted in their domicile, with a number of countries exempted except for those in Africa (Schain 2008). While these provisions were softened in the final version of the law, the intent was clearly to make it more difficult for Africans to reside in France. This system allowed the French government to control African immigration without resorting to American-style numerical quotas, which would have clashed with republican ideals of egalitarianism in visa requirements for citizens of developing countries and also would have been seen as discriminatory towards former colonies (Hollifield 1999).

The election of a socialist majority to the Assembly in 1997 led to another period of political cohabitation, this time with the right maintaining control of the presidency and the left gaining control of the office of Prime Minister. The Jospin government gave a high priority to immigration reform, promising to resolve the ambiguities of status created by the legal labyrinths of the Pasqua-Debré laws and re-establishing the republican foundations of immigration. The Interior Minister issued a circular on June 24, 1997 instructing préfets to proceed with case-by-case 
regularizations with provisions for the adjustment of status of spouses with irregular status and children of migrants with irregular status (Levinson 2005a).

A direct result of the sans-papiers movement and its widespread public support, this regularization program attracted 150,000 applications and eventually adjusted the status of 90,000 people, $85 \%$ of whom were regularized for family reasons (Levinson 2005a; Terray 2006). These regularizations, however, only allowed the granting of temporary, 1-year permits, thus prolonging the precarity of many groups of migrants and imposing the paradoxical burden of having to document their previous irregular status in order to gain access to more permanent residence permits (GISTI 2011).

While the 1997 regularization program sought to quickly resolve some of the contradictions of the Pasqua-Debré laws, the Jospin government also passed legislation to alter those laws. Drawing on the recommendations from a committee headed by Patrick Weil, a French historian of immigration, the 1998 Chevènement law (also known as the RESEDA law) included broad changes in the system of issuing residence permits designed to reinforce the rights of migrant families in France: minors brought to France for family reunification, foreigners who entered France before the age of 10, foreign parents of French children, and foreign spouses of French nationals would all receive initial 1-year residence permits (Hollifield 1999). The law also included a provision granting a residence permit to any foreigner able to prove residence in France for 10 years (Hollifield 1999). This provision gave rise to ongoing régularisations au fil de l'eau ("on-the-fly regularizations") during the following decade in which migrants from sub-Saharan Africa are over-represented (Lessault and Beauchemin 2009). The Jospin government also reformed the nationality code with the Guigou law of 1998, which reinstated limited jus soli provisions: individuals born in France could obtain French nationality at the age of 18 if they had lived in France for at least 5 years after age 11, or parents could request naturalization for minors as early as age 13 if the child had lived continuously in France for 5 years (i.e., since age 8) (Hollifield 1999).

Despite these changes and the assertions of the Jospin government that immigration was in keeping with the French republican tradition, the 1997-1998 laws continued many of the restrictive policies of the 1980s, including tightened visa requirements and provisions for detention and expulsion of irregular migrants (Schain 2008). Indeed, Schain (2008) argues that the trend in immigration policy in France has been towards a commitment to certain forms of control regardless of which political party holds office. This commitment has mostly been towards exclusion of immigrants, with right-wing governments tending towards tightening existing requirements; left-wing governments, on the other hand, have not attempted to roll back exclusionary restrictions but have merely increased judicial oversight (Schain 2008).

By 1997, then, the former preferential regime allowing free circulation of Senegalese had been completely dismantled by successive re-negotiations of treaties, and the general immigration-control system was modified in such a way as to limit entries of Senegalese and to make it difficult for them to stay and work legally in France. Thus the trend of the immigration-control system vis-à-vis Senegalese 
towards restriction has paralleled a similar movement in the overall regime. Some research points to the decline of the immigration of demographically valuable southern European migrants and the increase in racially and religiously distinct immigration from the former colonies as a main driver of this exclusionary impulse (Hollifield 1999); thus the evolution of restrictions on African migration to France cannot be separated from the exclusionary trend in the general immigration-control regime.

\subsubsection{The 2000s: Selective Immigration and Coordinated Migration Management}

Reorientation of French policy towards further restriction and selective immigration in the early 2000s gave rise to a new round of bilateral accords with Senegal and other countries that aimed at cooperative management of "unwanted" immigration flows in exchange for the opening of pathways to "wanted" immigration flows. Interior Minister Sarkozy pushed for a 2003 law in the wake of Chirac's 2002 faceoff with Jean-Marie Le Pen that toughened the provisions of the 1998 Chevènement legislation by easing the expulsion process and increasing the period of detention for irregular migrants to 32 days (Schain 2008). In addition, it reinstated some provisions of the Pasqua-Debré laws that the Chevènement law had abolished, such as the granting mayors the power to refuse entry to foreigners and strict controls on marriage with a foreign spouse. It also increased the waiting time for a permanent residence permit, and made the issuance of permanent and family-reunification permits contingent on proof of "good integration" (Schain 2008). As the 1945 ordonnance regulating immigration to France had seen 23 revisions (including 11 since the mid-1990s), the French government decided to consolidate the post-war measure into the "Code de l'entrée et du séjour des étrangers et du droit d'asile" (CESEDA) in 2005.

A second Sarkozy law was passed by the right in 2006 that reinforced some of the restrictive measures of the 2003 law while opening France to new kinds of immigration. The law allowed for some kinds of immigration choisie (selective immigration), mainly higher-skilled workers. This was paired with further restrictions on immigration subie (uncontrolled or non-selective immigration), including the requirement of the agreement to a contrat d'accueil et d'intégration (welcome and integration contract) for the issuance of family-reunification permits or permanent residence permits and the repeal of the provision for regularization of longterm residents and.

The push for selective immigration undergirded a new round "accords relatifs à la gestion concertée des flux migratoires et au codéveloppement" ("accords relating to the joint management of migratory flows and to codevelopment"), which ostensibly aimed to include developing countries such as Senegal in the coordinated management of migration flows. The French government founded these accords on the 
organization of some kinds of legal immigration, the fight against illegal immigration, and increased co-development efforts (see Kabbanji 2013 for an analysis of co-development programs). Senegal and France signed such a treaty on September 23, 2006 and it came into force on September 1, 2009. The treaty included provisions for issuance of residence permits that would permit a salaried activity to Senegalese with a job offer in any of ten listed professions (La Cimade 2009). While some of these professions, such as those in information technology, banking, and medicine, demanded high levels of skill and training, the list contained other, lessskilled professions in industry, agriculture, construction and building trades, and services (security, hairstyling, etc.).

In addition, the accord indicated that these residence permits were available to all Senegalese with a job offer in these professions, including those irregularly resident in France (La Cimade 2009). The treaty included provisions for Senegalese students in France and allowed for special categories of visas for business people, academics, scientists, artists, and athletes. As a counterweight to these measures to facilitate legal immigration, the treaty introduced new mechanisms for fighting illegal immigration. It included a readmission clause, whereby Senegal agreed to facilitate the return of Senegalese nationals found to be residing irregularly in France. The treaty also promised $€ 2.5$ million in funds for development projects and measures to encourage Senegalese migrants in France to invest their savings in businesses in Senegal (La Cimade 2009).

This new generation of treaties has come under fire for multiple reasons. Many of the measures for promoting legal immigration were already part of the CESEDA (such as the availability of visas for artists, scholars, athletes and other highly skilled professionals and a basic list of professions which were open to foreigners) (La Cimade 2009). Of more concern was the linking of increased control of irregular migration with development aid: it seemed that France was exchanging relatively meager sums and vague promises of co-development for readmission agreements that, in many ways, violated human rights (La Cimade 2009). Selective immigration as conceived under the 2006 Sarkozy law thus seemed to serve as rhetorical device for severely controlling migration from Africa while the bilateral accords paid lip service to the "special relationship" between France and her former colonial possessions.

\subsection{Senegalese Migration to New Destinations in Southern Europe}

The closing of the French border in the 1970s, high French unemployment, and the restructuring of French industries in the 1980s conspired with long-term economic decline in Senegal to lead Senegalese migrants to seek out new destinations in Southern Europe (Riccio 2008; Schoumaker et al. 2013). Senegalese migrants also responded to the demand for inexpensive and flexible workers in the secondary and 
informal labor markets as well as the relative ease of residential integration into Italy and Spain (Fall 2005; Pascual de Sans et al. 2000). These new destinations also attracted migrants from different social origins than earlier waves of labor migrants to France. Instead of originating in the rural Senegal River valley, migrants to Italy and Spain have tended to come from the predominantly Wolof zones of western Senegal and its urban areas (Schoumaker et al. 2013). In addition, the social networks that amplified this movement were embedded in religious affiliations, with the Senegalese Mouride Islamic brotherhood providing spiritual motivation and material support to its adherents in the new destinations (Babou 2002; Ebin 1992). Figure 2.1 shows the increasing importance of these new destinations: while stocks of Senegalese in France remain higher than those in Southern Europe, the number of Senegalese resident in Italy and Spain has grown dramatically since the 1990s (Mezger Kveder 2012).

Migration flows in general to Italy and Spain were rare prior to the 1970s, and neither country had effective immigration policies before the mid-1980s (Laubenthal 2007; Pascual de Sans et al. 2000). The accumulation of a large stock of illegal immigrants prior to these policies also necessitated a series of legalization programs, and each country has embarked on six regularization efforts since 1985 (Kraler 2009). There is some speculation that regularization programs in both countries actually attracted the first Senegalese migrants to these new destinations (Fall 2005; Kaag 2008; Tall 2008). These programs have undoubtedly had an impact on Senegalese migrants and migration patterns: a full $55 \%$ of all foreigners legalized in

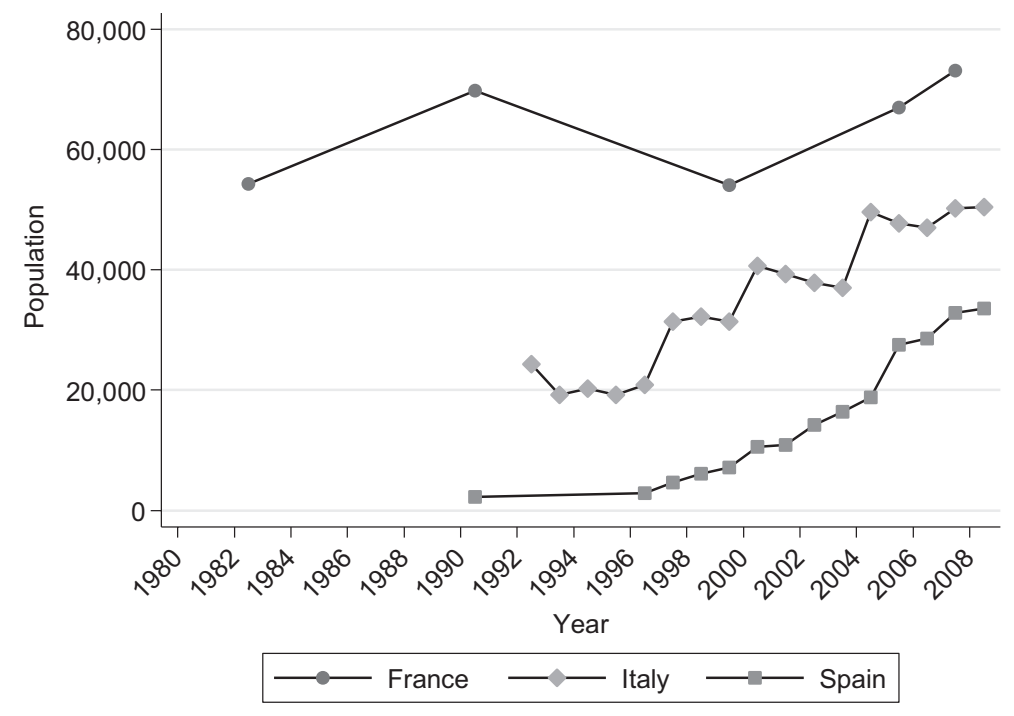

Fig. 2.1 Senegalese migrant stocks in France, Italy, and Spain (country of birth). Reproduced from Mezger Kveder (2012). Sources: United Nations Global Migration Database (UNGMD): France 1982, 1990; Spain 1990; Institut National de la Statistique et des Etudes Economiques: France 1999, 2005, 2007; Istat: Italy 1992-2008; Ministerio de Trabajo e Inmigración a partir de datos suministrados por Ministerio del Interior: Spain 1996-2008 
Spain's 1991-1992 program were from Africa (Pascual de Sans et al. 2000), and Senegalese are among the most numerous participants in Italy's regularization programs (de Haas 2008). ${ }^{2}$ Despite granting legal status, many of these regularization programs required renewal every few years, often leaving Senegalese migrants' legal status precarious and temporary.

The next two sections trace the development of immigration policies in Italy and Spain.

\subsection{Italy}

\subsubsection{Pre-1986: Italian Emigration and the Fragmentation of Immigration Policy}

The history of Italy's immigration-control policies is much more recent than France's and lacks almost all of France's bilateral relationship with Senegal. Most accounts of Italy's immigration policy emphasize that the country was, up until the 1970s, a net sender of migrants and thus had little practical need for a wellestablished system to control immigration (Sciortino 1999). Fascist-era laws between 1929 and 1931 dealt mostly with political immigration as a public-security issue and subsequent measures were fragmentary and mainly in the form of administrative circulars (Mezger and González-Ferrer 2013; Sciortino 1999).

\section{Mechanisms of Internal Control}

Despite this fragmentation, a law in 1961 (Legge 1961-5) repealing restrictions on internal migration allowed for the introduction of foreign labor through employer application to a local employment office (see Table 2.3 at the end of Sect. 2.4 for a synthesis of the evolution of immigration policy in Italy). If native workers were not available, the employment office was to issue a labor permit (autorzzazione al lavoro) and the foreigner could apply for a visa to enter Italy. The worker was issued a permesso di soggiorno per motivi di lavoro that was linked to a specific contract, meaning that residence authorization would end with the expiration of the contract (Sciortino 1999). This early law adumbrated some of the features of future Italian immigration-control policy, including the state brokerage of labor migration and the conditioning of residence permits on work authorizations and formal contracts.

Labor migration to Italy nonetheless remained limited through the 1980s, and most internal controls consisted of police checks for the "morality" and public order of immigrants (Sciortino 1999). Another law in 1981 was motivated by the

\footnotetext{
${ }^{2}$ Sub-Saharan Africans were also overrepresented in France's recent regularization programs (Lessault and Beauchemin 2009).
} 
Table 2.3 Synthesis of major immigration measures in Italy and consequences for migrant irregularity

\begin{tabular}{|c|c|c|}
\hline Date & Name of law & Consequence for irregularity \\
\hline $\begin{array}{l}\text { February } \\
10,1961\end{array}$ & $\begin{array}{l}\text { Legge 1961-5: Abrogazione della legislazione } \\
\text { sulle migrazioni interne e contro l'urbanesimo } \\
\text { nonchè disposizioni per agevolare la mobilità } \\
\text { territoriale dei lavoratori }\end{array}$ & $\begin{array}{l}\text { Allowed for the introduction } \\
\text { of foreign labor through } \\
\text { employer application to a } \\
\text { local employment office }\end{array}$ \\
\hline \multirow[t]{2}{*}{$\begin{array}{l}\text { September } \\
17,1966\end{array}$} & \multirow[t]{2}{*}{ Circolare n. 38, Ministero degli Affari Esteri } & $\begin{array}{l}\text { Exempted Senegalese citizens } \\
\text { from visa requirements for } \\
\text { entering Italy }\end{array}$ \\
\hline & & $\begin{array}{l}\text { Required Senegalese to } \\
\text { "regularize their position" if } \\
\text { they intended to "settle" }\end{array}$ \\
\hline $\begin{array}{l}\text { April 10, } \\
1981\end{array}$ & $\begin{array}{l}\text { Legge 1981-158: Ratifica ed esecuzione delle } \\
\text { convenzioni numeri 92, } 133 \text { e } 143 \\
\text { dell'Organizzazione internazionale del lavoro }\end{array}$ & $\begin{array}{l}\text { Ratified ILO convention on } \\
\text { rights of migrant workers }\end{array}$ \\
\hline $\begin{array}{l}\text { March 2, } \\
1982\end{array}$ & $\begin{array}{l}\text { Circolare del Ministero del lavoro n. 14194/IR/A: } \\
\text { Accesso all'impiego di lavoratori extracomunitari }\end{array}$ & $\begin{array}{l}\text { Froze issuance of work } \\
\text { permits for foreigners }\end{array}$ \\
\hline $\begin{array}{l}\text { December } \\
30,1986\end{array}$ & $\begin{array}{l}\text { Legge 1986-943: Norme in materia di } \\
\text { collocamento e di trattamento dei lavoratori } \\
\text { extracomunitari immigrati e contro le } \\
\text { immigrazioni clandestine }\end{array}$ & $\begin{array}{l}\text { Created framework for } \\
\text { introduction of foreign labor }\end{array}$ \\
\hline \multirow[t]{5}{*}{$\begin{array}{l}\text { February } \\
28,1990\end{array}$} & \multirow[t]{5}{*}{ Legge Martelli 1990-39 } & $\begin{array}{l}\text { Introduced visa requirements } \\
\text { for Senegal and other } \\
\text { countries }\end{array}$ \\
\hline & & $\begin{array}{l}\text { Allowed expulsion for the } \\
\text { management of irregular } \\
\text { migration }\end{array}$ \\
\hline & & $\begin{array}{l}\text { Continued recruitment of } \\
\text { labor with yearly quota decree }\end{array}$ \\
\hline & & $\begin{array}{l}\text { Required foreigners to apply } \\
\text { for residence permit within } \\
8 \text { days of arrival }\end{array}$ \\
\hline & & Regularization program \\
\hline \multirow[t]{2}{*}{$\begin{array}{l}\text { November } \\
18,1995\end{array}$} & \multirow{2}{*}{$\begin{array}{l}\text { Decreto-legge Dini 1995-489: Disposizioni urgenti } \\
\text { in materia di politica dell'immigrazione e per la } \\
\text { regolamentazione dell'ingresso e soggiorno nel } \\
\text { territorio nazionale dei cittadini dei Paesi non } \\
\text { appartenenti all'Unione europea }\end{array}$} & $\begin{array}{l}\text { Increased border-control } \\
\text { measures (rejections and } \\
\text { expulsions) }\end{array}$ \\
\hline & & Regularization program \\
\hline \multirow[t]{5}{*}{$\begin{array}{l}\text { July 25, } \\
1998\end{array}$} & \multirow[t]{5}{*}{$\begin{array}{l}\text { Legge Turco-Napolitano 40-1998: Disciplina } \\
\text { dell'immigrazione e norme sulla condizione dello } \\
\text { straniero }\end{array}$} & $\begin{array}{l}\text { Organized the entry of foreign } \\
\text { labor via a yearly quota } \\
\text { decree }\end{array}$ \\
\hline & & $\begin{array}{l}\text { Defined temporary 2-year } \\
\text { residence permits for work }\end{array}$ \\
\hline & & $\begin{array}{l}\text { Created indefinite residence } \\
\text { permit }\end{array}$ \\
\hline & & Regularization program \\
\hline & & Strengthened border control \\
\hline
\end{tabular}


Table 2.3 (continued)

\begin{tabular}{l|l|l}
\hline Date & Name of law & Consequence for irregularity \\
\hline $\begin{array}{l}\text { July 30, } \\
2002\end{array}$ & $\begin{array}{l}\text { Legge Bossi-Fini 2002-189: Modifica alla } \\
\text { normativa in materia di immigrazione e di asilo }\end{array}$ & $\begin{array}{l}\text { Reformed the quota system to } \\
\text { steer entries towards seasonal } \\
\text { work }\end{array}$ \\
& & $\begin{array}{l}\text { Tied length of residence } \\
\text { permit to work permit and } \\
\text { subjected renewal of } \\
\text { residence permit to a formal } \\
\text { work contract }\end{array}$ \\
\hline $\begin{array}{l}\text { Junereased severity of external } \\
\text { controls }\end{array}$ \\
\hline 2011 & Decreto-legge 2011-89 & $\begin{array}{l}\text { Regularization program } \\
\text { gllowed additional } \\
\text { governmental discretion in } \\
\text { case-by-case expulsions of } \\
\text { migrants found to be illegally } \\
\text { residing in Italy }\end{array}$ \\
\hline
\end{tabular}

ratification of the International Labour Organization convention on the rights of migrant workers but did not respond to then-increasing levels of immigration. The Ministry of Labor put a freeze on the issuance of work permits in 1982 in an effort to clamp down on irregular employment, which ultimately led to an increase in such employment (Sciortino 1999).

\section{Mechanisms of External Control}

Italy's system of external control was likewise limited during most of the twentieth century. While visas were technically required for entry to Italy, implementation of this requirement seems to have been "lax" into the 1970s (Sciortino 1999). Senegalese in particular were exempted from the visa requirement beginning in 1966. Following an exchange of diplomatic notes between Italy and Senegal, the Italian Ministry of Foreign Affairs issued a circular on September 17, 1966 exempting Senegalese citizens from visa requirements for entering Italy (Mezger and González-Ferrer 2013). This exemption was motivated by Senegal's previous decision to extend the regime of free circulation with France to all members of the European Common Market, including Italy; the Italian circular was thus reciprocal in nature and dependent on the bilateral relationship between Senegal and France. Despite exempting Senegalese from visa formalities, the circular still required them to "regularize their position" if they intended to "settle" in Italy.

While there is little information on Senegalese in Italy prior to the 1980s, some earlier accounts (Bergues 1973) indicate that Italy may have been a stepping stone in Senegalese migrants' journeys to France, perhaps because of this preferential visa regime. As mentioned above, Senegalese officials in the 1960s were concerned about the effects of emigration given the bilateral regime of free circulation between 
France and Senegal, and thus imposed the requirement of an exit visa for trips to France (Bergues 1973; Kane 2011). The same exit visa was not required for trips to Italy and other countries, so Senegalese occasionally traveled to Italy, which they were able to enter freely, and subsequently entered France under the conditions of the France-Senegal bilateral regime (Bergues 1973).

\subsubsection{6-1998: National-Level Immigration Policy and "Moral Panic"}

Italy passed its first major national-level legislation on immigration in December 1986. The legge 1986-943 outlined the rights of non-European Community foreign workers and formalized the "neo-corporatist" framework (Sciortino 1999) for the introduction of foreign labor that the 1961 law had sketched. A specialized division within the Ministry of Labor was responsible for keeping lists of both job vacancies and non-EU foreigners residing outside of and looking for work in Italy. This division would match foreign workers with vacancies if no native workers were available for the jobs, and provincial labor offices would then issue a work permit (autorizzazione al lavoro) that would allow the foreigner to apply for a visa to enter Italy. While the law does not specify how migrant workers would obtain residence permits, it does specify that work permits were valid for 2 years and that loss of a job prior to the expiration of the work permit was not grounds for revoking the residence permit. Unemployed migrants were encouraged to register on lists of job seekers so that they could be matched with vacancies.

This law, while initially seen as a positive step towards the construction of a rational immigration policy, ultimately created additional pathways into irregular status. The measure allowing unemployed migrants to stay in Italy and register as unemployed was motivated by a desire to give migrant workers more autonomy from employers, but it actually created a pseudo-legal category for migrants working in the shadow economy (Sciortino 1999): in an effort to avoid paying taxes and social insurance, migrants would register as unemployed and continue working informally. The law also contained provisions for the adjustment of status of foreigners with ongoing or past irregular employment with employers willing to regularize them (Reyneri 1998); applications initially had to be submitted within 3 months of the law's passage, but the deadline was extended into 1988 and eventually regularized the status of more than 118,000 people. Nonetheless, many migrants did not qualify for regularization, and new arrivals added to the resident population of migrants with irregular status (Sciortino 1999).

The next Italian law on immigration sought to deal with irregular migration by tightening external controls and security procedures coupled with numerical planning of labor entries. Legge 39 of 1990 (the "Martelli Law"), motivated in part by Italy's recent signing of the Schengen agreement and concomitant desire to reassure other European countries of the integrity of its borders, introduced visa requirements 
for many countries and made expulsion a tool for the management of irregular migration (Finotelli and Sciortino 2009). Indeed, it was at this time that the visa exemption for Senegal and other "immigration-risky countries" was rescinded (Sciortino 1999). In addition, the law continued the neo-corporatist recruitment of foreign labor by defining a yearly decreed quota of legal entries (Finotelli and Sciortino 2009).

In addition to these external controls, the law reformed the system of internal control by defining the conditions for access to the residence permit (permesso di soggiorno). Foreigners staying in Italy for purposes other than tourism needed to apply for a residence permits within 8 days of arrival; the permit, available only to those who entered legally, could last for up to 2 years and was renewable. The law also included a liberal regularization program open to any foreigners residing in Italy before December 31, 1989, which adjusted the statuses of 234,841 migrants (Sciortino 1999). This patchwork of restrictive controls on entries combined with rigid planning tools and a liberal regularization program led to the law's ineffectiveness. With regard to the yearly quota, many employers and foreign workers found the process cumbersome, leading to the informal hiring of irregular migrants (Finotelli and Sciortino 2009).

Growing "moral panic" (Sciortino 1999) over increasing immigration paralyzed further attempts at immigration-policy reform during most of the decade of the 1990s. The government passed an executive decree (the "Dini decree," decretolegge 489) in 1995 that included both harsh border-control measures (expulsions and rejections) to please the populist right-wing Lega Nord (Northern League) and a regularization program to mollify the left (Sciortino 1999). The decree was not enacted within 60 days as mandated by the constitution, so it was re-issued several times over the following year with the same fate (Sciortino 1999). Nonetheless, the government went ahead with the decree's regularization program, which was stricter than the Martelli amnesty: applicants had to prove that they had been residing in Italy, regularly employed during the past 6 months or with an employment offer, and had paid 3 months of social security contributions (Levinson 2005b). Despite these more stringent conditions, the program adjusted the status of 238,000 foreign workers from 1995 to 1996 (Levinson 2005b).

The passage of legge 40 in 1998, also known as the Turco-Napolitano law, put an end to the legislative impasse on immigration policy. Motivated in part by the longawaited accession of Italy to the Schengen zone, this law attempted to offer a comprehensive framework for both management and control measures (Finotelli and Sciortino 2009). The law once again organized the entry of foreign labor via a yearly quota decree. Employers would request a work permit (autorizzazione al lavoro) and entry visa within the quota system, potentially for a specific foreigner who could then apply for the visa abroad. Unlike previous Italian quota systems, though, the Turco-Napolitano law did not require proof of the lack of suitable Italian workers (Reyneri 2004). This requirement had effectively limited legal entries under the quota system to less than 25,000 per year before 1999, making it extremely difficult to enter Italy legally for work (Reyneri 2004). 
In addition to re-establishing the quota system, the law also attempted to promote the integration of migrants by stabilizing their residence situations. Foreigners arriving for work would enter Italy with a visa based on the pre-existing autorizzazione al lavoro and apply for a 2-year permesso di soggiono per lavoro subordinato after arrival. The law defined different lengths for the permesso depending on the motive for the stay: six to 9 months for seasonal work; 1 year for study; and 2 years for self-employment, indefinite-contract employment, and family reunification. Unemployed workers were allowed to keep their residence permits if they registered as unemployed. In addition, the law introduced an indefinite residence permit (carta di soggiorno) accessible after 5 years of legal residence (Finotelli and Sciortino 2009). The implementation of the law also included a regularization program open to unauthorized immigrants present in Italy before March 27, 1998, which ultimately adjusted the status of 193,200 of over 300,000 applicants (Levinson 2005b).

While the Turco-Napolitano law promoted the legal entry, residence, and work of migrants, it also included measures to strengthen border control, make irregular entry more difficult, and facilitate expulsion via readmission agreements (Finotelli and Sciortino 2009). Despite these restrictive measures, the law was unable to deal with the strategy of visa overstaying, which was overtaking clandestine entry as an irregular migration strategy (Finotelli and Sciortino 2009).

\subsubsection{The 2000s: "Strong Restrictive Ambition"}

The Bossi-Fini law of 2002 (legge 189), passed by the second Berlusconi government, was "inspired by a strong restrictive ambition" (Finotelli and Sciortino 2009: 126). The law reformed the quota and internal-control systems so as to limit legal entries. Political discretion in the definition of yearly quotas increased, with the goal of steering legal entries towards temporary, seasonal work. The law subjected residence permits to increased administrative scrutiny through decreased length, and also tied the length of the residence permit to the work permit via the contratto di soggiorno per lavoro (residence contract for work) (Finotelli and Sciortino 2009). This contract, signed by the employer and the employee after recruitment through the quota system, required employers to pay housing and repatriation costs and allowed foreigners to apply for a permesso di soggiorno per motivi di lavoro (residence permit for reasons of work), valid 1 year for fixed-duration contracts and 2 years for unlimited-duration contracts. This law also made renewal of residence permits contingent on having a formal work contract, potentially subjecting many migrants to spells of irregularity (Finotelli and Sciortino 2009).

In addition to limiting legal entries, the Bossi-Fini law sought to combat irregular immigration through the increasing severity of external controls. These included granting powers to the Navy to control ships at sea suspected of carrying potential clandestine migrants, increasing the maximum detention time for irregular migrants to 60 days, and levying steeper sanctions on migrant traffickers and smugglers (Finotelli and Sciortino 2009). Despite these increased external controls and the 
law's restrictive ambition, the legislation also included yet another massive regularization program. While framed as a "humanitarian" amnesty for undocumented caretakers of children and the elderly, the program only required work documentation in the form of 3 months of pension contributions and proof of continued employment (Levinson 2005b). The program adjusted the status of 634,700 of 700,000 applicants by granting them 1-year residence permits, with a possible extension of 6 months if the migrant had lost the job and needed to look for work (Levinson 2005b). The Bossi-Fini law thus was unable to reconcile its restrictive ambitions with the structural reality of immigration to Italy, and the Berlusconi government eventually accepted the need for new workers and increased the yearly quota (Finotelli and Sciortino 2009).

Subsequent governments did not pass any major immigration legislation in the period under review. A center-left government elected in 2006 campaigned on an overhaul of the system but was unable to muster the parliamentary majority necessary to pass legislation. The return of a Berlusconi government in 2008 signaled a return to restrictionist policies, this time through the introduction of public-security measures designed to facilitate deportation of migrants convicted of certain crimes (legge 125-2008). A 2011 law (decreto-legge 89, legge 129) allowed additional governmental discretion in case-by-case expulsions of migrants found to be illegally residing in Italy. According to Finotelli and Sciortino (2009),these kinds of restrictionist measures are in keeping with the trend in Italian immigration policy, which has increasingly focused on external control while ignoring the structural mechanisms - such as the size of the Italian informal economy - that sustain irregular migration in Italy. In addition, Italy's quota system acts as a de facto amnesty by allowing irregular migrants already present in Italy and working in the informal economy to apply for jobs in the formal sector and access legal status via the quota's mechanisms (Fasani 2010).

\subsection{Spain}

\subsubsection{0s-1999: European Integration}

Like Italy, Spain was traditionally a country of emigration and thus little attention was paid to legislation regulating immigration before the 1980s. Spain shares a number of other factors with Italy in the evolution of immigration policy, including the lack of a historical relationship with Senegal and many (although not all, as Latin-American migration to Spain attests) of the countries that eventually would send it migrants; recourse to frequent regularization programs as a method for dealing with recurrent irregular migration; and the economic underpinnings of large secondary and informal sectors (Reyneri 2003).

Much of Spain's legislation on internal control mechanisms arose prior to the increase in the foreign-born population in the 2000s and prior to Senegalese 
migration in the 1990s. A Franco-era decree ${ }^{3}$ took some steps to define the regulations governing the entry of foreigners: valid passports were required, and those foreigners who were required to have a visa had to apply for it prior to arrival (see Table 2.4 for a synthesis of the evolution of immigration policy in Spain). Although there is no existing list of nationalities subject to visa requirements at that time, experts have stated that Senegalese were certainly subject to this requirement. ${ }^{4}$ Unlike both France and Italy, then, Senegalese were always at least formally required to have a visa to enter Spain.

The first national-level law on immigration was passed in 1985 in response to Spain's integration into the European Community and the wariness of Spain's European neighbors regarding the permeability of its borders (Calavita 1998, 2003). The Ley Organica 7/1985 on "the rights and liberties of foreigners in Spain" required all foreigners entering Spain to have an entry visa, with exceptions for those nationals exempted under international treaties (which did not include Senegalese). Foreigners staying for longer than 90 days were required to have a residence permit (permiso de residencia), the period of validity of which could not exceed 5 years. Foreigners wishing to establish residency for work were required to submit a formal work contract from an employer and apply for a work permit (permiso de trabajo) in addition to a residence permit.

While issued by separate Ministries, the residence and work permits would be of the same duration and in the form of a single document, and both could be renewed during a single procedure. Temporary work authorizations for durations of less than 90 days did not require a residence permit but were still contingent on legal residence. The law also spelled out the legal grounds for expulsion of migrants, including lack of a residence permit or working without a work permit. This law did not, however, contain any provisions for family reunification or permanent residence (González-Enríquez 2010), although the application decree of 1986 did provide for a family-reunification visa. In addition to external and internal mechanisms of control, the law also defined the rights of foreigners, but conditioned the granting of these rights on legal residence in Spain (Calavita 1998).

These measures were thus restrictive in nature, and Calavita (1998) argues that the provisions of this law that required visas, residence permits, and work permits immediately plunged the majority of immigrants residing in Spain at that time into irregular status. The law thus also contained provisions for a regularization program, eligibility for which was conditional on migrants being able to have legitimate continuing work contracts or other formal means of support and to have resided in Spain before July 24, 1985 (Levinson 2005c). Only 44,000 migrants applied for regularization under this program (between $25 \%$ and $50 \%$ of those eligible to do so), and only 23,000 were able to successfully adjust status. The program was also criticized for making it difficult for immigrants to renew their regularized status, meaning many subsequently fell back into irregularity (Levinson 2005c).

\footnotetext{
${ }^{3} \mathrm{~A}$ decreto (decree) is an administrative action used by the executive branch to establish regulations that make it possible to carry out existing law and thus has a normative rank below that of a ley (law) (Mezger and González-Ferrer 2013).

${ }^{4}$ Amparo González-Ferrer, personal communication, November 15, 2012.
} 
Table 2.4 Synthesis of major immigration measures in Spain and consequences for migrant irregularity

\begin{tabular}{|c|c|c|}
\hline Date & Name of law & Consequence for irregularity \\
\hline $\begin{array}{l}\text { February } \\
14,1974\end{array}$ & $\begin{array}{l}\text { Decreto 522/1974, de } 14 \text { de febrero, por el } \\
\text { que se regula el régimen de entrada, } \\
\text { permanencia y salida de los extranjeros en } \\
\text { España }\end{array}$ & $\begin{array}{l}\text { Required valid passport and } \\
\text { pre-arrival visa for entry }\end{array}$ \\
\hline \multirow[t]{5}{*}{$\begin{array}{l}\text { July } 1 \text {, } \\
1985\end{array}$} & \multirow[t]{5}{*}{$\begin{array}{l}\text { Ley Organica 7/1985 Sobre derechos y } \\
\text { libertades de los extranjeros en España }\end{array}$} & $\begin{array}{l}\text { Required all foreigners entering } \\
\text { Spain to have an entry visa and to } \\
\text { apply for a residence permit for } \\
\text { stays exceeding } 90 \text { days }\end{array}$ \\
\hline & & $\begin{array}{l}\text { Required submission of formal } \\
\text { work contract and work permit for } \\
\text { employment }\end{array}$ \\
\hline & & $\begin{array}{l}\text { Expulsion of migrants possible if } \\
\text { lacking residence and/or work } \\
\text { permit }\end{array}$ \\
\hline & & $\begin{array}{l}\text { Rights conditional on legal } \\
\text { residence }\end{array}$ \\
\hline & & Regularization program \\
\hline 1991 & Administrative action & Regularization program \\
\hline 1993 & Decision by Council of Ministers & $\begin{array}{l}\text { Introduced a quota system for } \\
\text { foreign workers }\end{array}$ \\
\hline \multirow[t]{3}{*}{$\begin{array}{l}\text { February 2, } \\
1996\end{array}$} & \multirow[t]{3}{*}{ Real Decreto 155/1996 } & $\begin{array}{l}\text { Defined multiple kinds of entry } \\
\text { visas }\end{array}$ \\
\hline & & $\begin{array}{l}\text { Made the issuance of residence and } \\
\text { work permits dependent on having } \\
\text { entered with the corresponding type } \\
\text { of visa }\end{array}$ \\
\hline & & Continued quota system \\
\hline \multirow[t]{7}{*}{$\begin{array}{l}\text { January 11, } \\
2000\end{array}$} & \multirow{7}{*}{$\begin{array}{l}\text { Ley Organica 4/ 2000: Sobre derechos y } \\
\text { libertades de los extranjeros en España y su } \\
\text { integración social }\end{array}$} & $\begin{array}{l}\text { Irregular residence and work not } \\
\text { grounds for expulsion }\end{array}$ \\
\hline & & $\begin{array}{l}\text { Granted social rights to documented } \\
\text { and undocumented migrants with } \\
\text { Padrón registration }\end{array}$ \\
\hline & & $\begin{array}{l}\text { Increased validity of temporary } \\
\text { residence and work permits to } \\
5 \text { years }\end{array}$ \\
\hline & & $\begin{array}{l}\text { Created permanent permits for } \\
\text { foreigners with } 5 \text { years of renewals } \\
\text { of temporary residence or work } \\
\text { permits }\end{array}$ \\
\hline & & $\begin{array}{l}\text { Granted temporary residence } \\
\text { permits to foreigners with two } \\
\text { uninterrupted years of residence }\end{array}$ \\
\hline & & Formalized quota system \\
\hline & & Regularization program \\
\hline
\end{tabular}


Table 2.4 (continued)

\begin{tabular}{|c|c|c|}
\hline Date & Name of law & Consequence for irregularity \\
\hline \multirow[t]{7}{*}{$\begin{array}{l}\text { December } \\
22,2000\end{array}$} & \multirow{7}{*}{$\begin{array}{l}\text { Ley Organica 8/2000: de } 22 \text { de diciembre, } \\
\text { de reforma de la Ley Orgánica } 4 / 2000, \text { de } 11 \\
\text { de enero, sobre derechos y libertades de los } \\
\text { extranjeros en España y su integración } \\
\text { social. }\end{array}$} & $\begin{array}{l}\text { Reinstated expulsion as a sanction } \\
\text { for irregular residence or work }\end{array}$ \\
\hline & & $\begin{array}{l}\text { Increased to } 5 \text { years period of } \\
\text { continuous residence for granting of } \\
\text { temporary residence permit }\end{array}$ \\
\hline & & $\begin{array}{l}\text { Temporary residence permits were } \\
\text { contingent on possessing the } \\
\text { appropriate administrative } \\
\text { authorization to work }\end{array}$ \\
\hline & & $\begin{array}{l}\text { Renewal of work permit contingent } \\
\text { on ongoing work contract }\end{array}$ \\
\hline & & Continued quota system \\
\hline & & Regularization program \\
\hline & & $\begin{array}{l}\text { Introduced regularization for } \\
\text { arraigo }\end{array}$ \\
\hline \multirow[t]{3}{*}{$\begin{array}{l}\text { November } \\
20,2003\end{array}$} & \multirow[t]{3}{*}{ Ley Organica $14 / 2003$} & $\begin{array}{l}\text { Required foreigners to renew their } \\
\text { Padrón registration every } 2 \text { years }\end{array}$ \\
\hline & & $\begin{array}{l}\text { Required combined work and } \\
\text { residence visa for entry for work }\end{array}$ \\
\hline & & $\begin{array}{l}\text { Eliminated ability to acquire } \\
\text { residence permit based solely on } \\
\text { duration of residence, but arraigo } \\
\text { provision retained }\end{array}$ \\
\hline \multirow[t]{3}{*}{$\begin{array}{l}\text { December } \\
30,2004\end{array}$} & \multirow[t]{3}{*}{ Real Decreto 2393/2004 } & $\begin{array}{l}\text { Laid out in detail the link between } \\
\text { different categories of visas and the } \\
\text { residence and work permits }\end{array}$ \\
\hline & & $\begin{array}{l}\text { Specified the individual } \\
\text { regularization procedures associated } \\
\text { with arraigo }\end{array}$ \\
\hline & & "Normalization" program \\
\hline \multirow[t]{2}{*}{ July 2006} & \multirow[t]{2}{*}{ Plan África } & $\begin{array}{l}\text { Cooperation with migrant-sending } \\
\text { countries in matters of border } \\
\text { surveillance and readmission of } \\
\text { irregular migrants }\end{array}$ \\
\hline & & Increased development assistance \\
\hline
\end{tabular}

While no new immigration legislation would be passed before the turn of the century, the Spanish government pursued piecemeal reforms through other legal mechanisms. Due in part to the failure of the 1985 regularization program, the Spanish government, through a decision in the Council of Ministers communicated by a resolution, carried out another regularization program in 1991. Although not part of a legislative reform, this administrative action recognized the limitations of the previous approach by specifically targeting migrants who had previously possessed a residence permit; the measure thus sought to resolve some of the ambiguity introduced by the difficulty in renewing regularized status. Additional requirements were an ongoing formal work contract or self-employment in a lucrative enterprise, 
and residence in Spain prior to May 15, 1991 (Calavita 1998). Almost 110,000 migrants were regularized by this program, out of an applicant pool of 135,000 (Levinson 2005c).

The Spanish Council of Ministers again took a non-legislative route to the reform of immigration policy when it introduced a quota system for foreign workers in 1993. This initial foray defined three sectors where local labor was deemed to be lacking — agriculture, construction, and basic services—and created mechanisms by which foreign workers could be recruited to fill vacancies (Calavita 1998). The system only managed to fill 5220 of the 20,600 slots set aside, mostly because of administrative hurdles that employers were unable or unwilling to jump over (Calavita 1998). Rules were subsequently loosened, and the government continued to define a quota for foreign recruitment throughout the 1990s.

In 1996 the Spanish government issued a decree (Real Decreto 155/1996) specifying regulations for the application of the 1985 law. This decree defined multiple kinds of entry visas and made the issuance of residence and work permits dependent on having entered with the corresponding type of visa. The quota system for the recruitment of foreign labor was continued. The internal control mechanisms remained similar to those defined in the 1985 law, with the exception of the introduction of permanent residence and work permits, which could be granted to a foreigner who had lived and worked in Spain continuously and in a regular situation for at least 5 years. These permanent permits were valid for 5 years and automatically renewable. Solé and Parella (2003) argue that the introduction of these permits was an important step towards recognizing the permanent nature of immigration to Spain in that it recognized migrants' rights to settle and improve their working conditions. Finally, the decree also included a regularization program targeted specifically at foreigners who had fallen into irregularity after having gained residence and work permits through previous regularization programs (Reyneri 2003), which succeeded in adjusting the statuses of 21,300 foreigners (Levinson 2005c).

\subsubsection{0-2008: Rights and Freedoms of Foreigners, Alien Affairs, and Plan África}

The start of the twenty-first century saw a flurry of immigration legislation in Spain, and the initial trend was towards increased tolerance of irregular migrants. A new Organic Law (Ley Organica 4/2000) on the "Rights and Freedoms of Foreigners and their Social Integration" was passed by the opposition left-wing coalition in January 2000 and was mostly concerned with protecting the rights and facilitating the integration of migrants in Spain. The law recognized the enduring presence of migrants with irregular status in the country: although it defined irregular residence and work as serious infractions punishable by a fine, they were not grounds for expulsion (Calavita 2003). Additionally, the law granted a wide array of social rights to education, political participation, and health care to both documented and 
undocumented migrants as long as they were registered in the Padrón municipal (González-Enríquez 2010). This provision meant an end to the statistical invisibility of irregular migrants in Spain. Huge numbers of irregular migrants registered with the Padrón, leading to the realization that upwards of $50 \%$ of non-EU foreigners were in Spain illegally as of 2003 (González-Enríquez 2009).

For internal control, the law maintained the system of temporary residence and work permits for stays of longer than 90 day, but increased their length of validity to up to 5 years. In addition, the law created a permit for permanent residence for foreigners with 5 years of temporary residence and a permanent work permit for foreigners who had renewed temporary permits for 5 years in a row. Any foreigner with two uninterrupted years of residence in Spain could be granted a temporary residence permit, conditional on registration with the municipal authorities. In addition, the law prescribed another regularization program, open to foreigners residing in Spain before June 1, 1999 who had either possessed or applied for a residence or work permit in the three previous years. The program eventually regularized 153,463 foreigners (Levinson 2005c). The law also formalized the quota system introduced in the 1996 decree, making legal immigration for work possible, in theory.

A counter-reformation of this law came quickly, however, in the form of another Organic Law (Ley Organica 8/2000) on "alien affairs," which was approved in December 2000 and came into effect in January 2001.The center-right Popular Party had won an outright parliamentary majority in March 2000 and made the reform of the liberal immigration law from January a public issue. The reform law succeeded in rolling back some of the more lenient provisions of its predecessor: expulsion was reinstated as a sanction for irregular residence or work, and the period of continuous residence after which irregular migrants could gain a temporary residence permit was increased to 5 years from 2 . There were also changes to the system of internal control: temporary residence permits were contingent on possessing the appropriate administrative authorization to work (autorización administrativa para trabajar), while the law also stated that a residence permit was required in addition to a work permit. In addition, renewal of the work permit was only possible with an ongoing work contract.

These provisions made it more difficult for migrants, often working in the informal economy, to access residence permits and also made gaps in legal residence possible for migrants possessing a work permit. The law reaffirmed the continuation of the quota system and called for a new amnesty program targeted at those who were denied regularization during the 2000 amnesty because they had not resided in Spain prior to June 1, 1999. This re-examination resulted in the regularization of 232,674 foreigners (Kraler 2009). The law also allowed the regularization of status for reasons of "arraigo" (rootedness), and an additional regularization program between June and August adjusted the status of 13,735 foreigners, who had to prove residence in Spain prior to January 23, 2001 (Lorenzo 2002).

By 2003, the proportion of foreigners residing in Spain without a residence permit is estimated to have reached over $50 \%$, and public concern about irregular migration was growing (González-Enríquez 2009). The center-right ruling party 
and the leftist opposition agreed to another reform of the 2000 law on foreigners. This reform law (Ley Organica 14/2003) translated concerns about irregular migration into new restrictive measures. It allowed the Interior Ministry to access the data on foreigners contained in the Padrón for police purposes (although the Ministry has not yet done so), and required foreigners to renew their Padrón registration every 2 years (González-Enríquez 2009). The law specified new categories of visas, including a residence visa that precluded work and a work and residence visa for foreigners wishing to work in Spain. A work and residence visa would be necessary for the granting of an autorización administrativa para trabajar, which would allow a migrant to reside in Spain for its duration, effectively creating a single permit (even though migrants were still required to obtain residence permits). The possibility of acquiring a residence permit based on the amount of time spent in Spain (2 years in Law 4/2000, and 5 years in Law 5/2000) was eliminated completely; ongoing regularization was available only through a provision for arraigo (González-Enríquez 2009).

The socialist party won the general election in March 2004 and issued additional regulations for the application of the Foreigners Law in August of the same year (Real Decreto 2393/2004). The regulations laid out in detail the link between different categories of visas and the residence and work permits to which they were linked. Employers wishing to hire a foreigner were required to submit applications for work permits while the foreigner was abroad; the foreigner could then apply for a work and residence visa, which would allow temporary residence in Spain. The law specified the individual regularization procedures associated with arraigo, which could be for either social or work reasons. For regularization for social attachment, foreigners had to live in Spain for 3 years and prove that they had either a work contract or "social insertion" in their place of residence as certified by a report from city hall or from legal migrants to which the foreigner was related. Another provision for workplace rootedness allowed foreigners to adjust their status after living in Spain for 2 years with a labor relationship with an employer for at least 1 year.

Both of these individual regularization procedures would result in the issuance of temporary residence permits. In addition to these individual regularization mechanisms, the regulations included a "normalization" program designed to address Spain's large underground economy (González-Enríquez 2009). Employers had to apply for the regularization of their foreign workers with the guarantee of a formal contract with a validity of at least 6 months; foreigners had to be registered with the municipality and have resided in Spain for 6 months prior to the passage of law 2000/4. Carried out between February and May 2005, the program received 700,000 applications, of which 578,000 were accepted, with 550,000 signing up to begin paying into social security (Levinson 2005c). Finally, the regulations reformed the quota system once again: it emphasized hiring migrants in their country of origin and published a quarterly list of openings by province (González-Enríquez 2009). 


\section{The Arrival of the Cayucos in the Canary Islands and Spain's "Plan África"}

The year following this regularization program saw the arrival in rickety fishing boats of over 30,000 clandestine migrants on the shores of Spain's Canary Islands. The boats departed from locations on the coast of West Africa in Mauritania, Senegal, and Guinea-Bissau and carried sub-Saharan Africans as well as, in far lesser proportion, Pakistanis, Indians, Afghans, and Iraqis (Charles 2007). Spanish authorities quickly became concerned about the possibility of a massive "invasion" of undocumented Africans and rushed to put into place an "Africa Plan" (Plan África) in early 2006 that would stop this unwanted flow (Charles 2007; Gagrielli 2008). This plan included increased cooperation with migrant-sending countries in matters of border surveillance and readmission of irregular migrants in exchange for development assistance (Gagrielli 2008). An initial agreement between the Senegalese and Spanish governments in May 2006 paved the way for the repatriation of 623 Senegalese nationals identified in the Canary Islands.

The first flight containing 99 deported Senegalese migrants in handcuffs landed in Dakar in early June, and the press coverage of this event forced the Senegalese government to temporarily stop repatriations (Gagrielli 2008). The Spanish government promised a $€ 20$ million loan to Senegal on June 16, and additional deportations of 189 Senegalese migrants took place between June 19 and 24. In addition, Senegal agreed to cooperate with Spain in patrols of Senegalese territorial waters. Dakar and Madrid signed a series of formal bilateral accords in December 2006 on the emigration of minors and the fight against criminality, but were unable to conclude treaties on cooperative migration management or readmission of irregular migrants (Gagrielli 2008). The Spanish quota for 2008 included provisions for Senegalese workers, and at least 140 Senegalese were selected for 12-month work contracts in Spain between 2006 and 2007 (Charles 2007).

\subsection{Conclusion}

The evolution of immigration policies in France, Italy, and Spain demonstrates that contexts of reception for Senegalese migrants in Europe have varied widely both within these destinations over time and between these destinations. It may be useful to recall Portes's typology of negative, neutral, and advantaged contexts of reception (Portes and Böröcz 1989; Portes and Rumbaut 2006) to make sense of this variation. In France, there has been an evolution from colonial-era political and personal "assimilation" of Senegalese originaires into the French nation alongside and exclusion of other Senegalese "subjects" from the French nation; to a postindependence preferential regime that put few restrictions on the ability of Senegalese to enter, reside, or work in France; to an alignment of the bilateral relationship with Senegal with the general immigration-control regime via the gradual erosion of the preferential regime. Contexts of reception in France for Senegalese 
have thus varied from somewhat advantaged in the colonial (for originaires) and immediate postcolonial periods, to neutral with the first erosions of the preferential regime, to negative when Senegalese were fully subject to the restrictive general system of immigration control. This restrictive system has furthermore been marked by discrimination against and stigmatization of Africans (Adida et al. 2010) and somewhat blatant attempts to limit flows of migrants from Africa (Schain 2008). While France seems to have acknowledged the formerly privileged status of Senegalese in its most recent bilateral migration-management accord with Senegal, the basic parameters of the context of reception remain restrictive and negative.

The contexts of reception in Italy and Spain have differed from those in France, especially in their timing and in the imposition of immigration restrictions. Attitudes of the host society towards irregular migrants have also varied over time and between countries. These southern European contexts of reception were never advantaged for Senegalese migrants, with the possible exception of the pre-1990 period in Italy when Senegalese were exempt from visa requirements. Contexts of reception in these two countries have thus mostly been negative with regard to Senegalese migrants, in that they faced the same set of increasingly restrictive immigrationcontrol measures as most other migrants. These differences underscore the importance of incorporating multiple contexts of reception into analyses of the production and consequences of irregular migration.

Recent research on the broader evolution of immigration policy across many countries can shed light on the general evolution towards restrictiveness in the three main contexts of reception of Senegalese migrants. The DEMIG project analyzed the long-term evolution of migration policies in 45 countries between 1945 and 2014 and found that border control policies have become more restrictive, while entry and integration policies have become less so (de Haas et al. 2016). Analyses of policy evolution in OECD countries by the Immigration Policies in Comparison (IMPIC) project revealed similar trends: between 1980 and 2010 migration policies became more liberal for labor, humanitarian, and family policies but more restrictive for control measures including border crossing and irregular migration (Helbling and Kalkum 2017). These comparative projects confirm the trend towards increasing restrictiveness in some facets of the contexts of reception facing Senegalese migrants in France, Italy, and Spain.

This chapter has shown that variations in contexts of reception have produced a variety of socio-legal configurations that give rise to different pathways of irregularity. Senegalese in France had de facto regular status for much of the 1960s and 1970s in that they did not need explicit authorization to enter or reside in France and were able to take advantage of common post facto regularization procedures. Irregularity became more common among Senegalese as this preferential regime crumbled, and the massive participation of Senegalese and other Africans in the sans papiers movement in the mid-1990s highlighted the extent to which changes in immigration-control legislation had created precarity in their legal statuses.

Irregularity seems to have been a consistent component in contexts of reception in Italy and Spain, as their frequent and massive regularization programs demonstrate. Much of this irregularity seems to stem from the mismatch between restric- 
tive immigration-control measures and structural demands for cheap, low-skilled labor (Finotelli and Sciortino 2009; González-Enríquez 2009; Reyneri 2003), echoing similar dynamics in the US (Massey et al. 2002; Portes 1978).

These dynamics illustrate that irregularity is very much a manufactured state rather than a characteristic of the migrants themselves. It is produced when governments impose rules and regulations on flows that arose largely for economic reasons and were extended by social mechanisms of network formation. These legal impositions are undertaken mostly in response to shifts in domestic political sentiment over time and are uninformed by any understanding of migratory processes themselves, yielding policies and regulations that are inconsistent over time and often contradictory at any given moment, thus producing irregularity. Migration that is judged legal at one time can thus become illegal at a later date not because of any change among migrants or the basic process of immigration, but because of arbitrary shifts in policy made without regard to the practical realities of international migration.

\section{References}

Adida, C. L., Laitin, D. D., \& Valfort, M.-A. (2010). Identifying barriers to Muslim integration in France. Proceedings of the National Academy of Sciences of the United States of America, 107(52), 22384-22390.

Alaux, J.-P. (2001). À La Rue Sous Prétexte de Polygamie. Plein Droit, 51, 10.

Amin, S. (Ed.). (1972). Modern migrations in Western Africa: Studies presented and discussed at the eleventh international African seminar, Dakar, April 1972. London: published for the International African Institute by Oxford University Press.

Amin, S. (1995). Migrations in contemporary Africa: A retrospective view. In J. Baker \& T. A. Aina (Eds.), The migration experience in Africa. Uppsala: Nordiska Afrikainstitutet.

Babou, C. A. (2002). Brotherhood solidarity, education and migration: The role of the Dahiras among the Murid Muslim community of New York. African Affairs, 101(403), 151-170.

Beauchemin, C., \& González-Ferrer, A. (2011). Sampling international migrants with origin-based snowballing method: New evidence on biases and limitations. Demographic Research, 25, 103-134.

Beauchemin, C., Caarls, K., \& Mazzucato, V. (2013). Senegalese migrants between here and there: An overview of family patterns. MAFE Working Papers (MAFE Working Paper 33). Paris: INED.

Bergues, H. (1973). L'immigration Des Travailleurs Africains Noirs En France et Particulièrement Dans La Région Parisienne. Population, 28(1), 59-79.

Bredeloup, S. (1993). Les Migrants Du Fleuve Sénégal : A Quand La « Diams'pora »? Revue Européenne de Migrations Internationales, 9(3), 205-232.

Brochmann, G. (1999). The Mechanisms of control. In G. Brochmann \& T. Hammar (Eds.), Mechanisms of immigration control: A comparative analysis of European regulation policies (pp. 1-27). Oxford: Berg.

Calavita, K. (1998). Immigration, law, and marginalization in a global economy: Notes from Spain. Law \& Society Review, 32(3), 529-566.

Calavita, K. (2003). A 'reserve army of delinquents': The criminalization and economic punishment of immigrants in Spain. Punishment \& Society, 5(4), 399-413.

CERC-Association. (1999). Immigration, Emploi, et Chômage: Un État Des Lieux Empirique et Théorique (Vol. 3). Paris: CERC-Association. 
Charles, C. (2007). Le double jeu de l'Espagne. Plein droit, 73(2), 26-30.

Cimade, L. (2009). Les Accords Relatifs à La Gestion Concertée Des Flux Migratoires et Au Codéveloppement. Paris: La Cimade.

Coquery-Vidrovitch, C. (2001). Nationalité et Citoyenneté En Afrique Occidentale Français: Originaires et Citoyens Dans Le Sénégal Colonial. The Journal of African History, 42(2), 285-305.

Crowder, M. (1967). Senegal: A study of French assimilation policy (Revised ed.). London: Methuen. Distributed in the U.S. A. by Barnes \& Noble.

de Haas, H. (2007a). Irregular migration from Africa to Europe: Questioning the transit hypothesis. International Migration Institute.

de Haas, H. (2008a). Irregular migration from West Africa to the Maghreb and the European Union: An overview of recent trends. Geneva: International Organization for Migration.

de Haas, H., Natter, K., \& Vezzoli, S. (2016). Growing restrictiveness or changing selection? The nature and evolution of migration policies. International Migration Review. https://doi. org/10.1111/imre.12288.

Dedieu, J.-P. (2011). Associations subsahariennes : de la liberté d'association à la liberté surveillée. Plein droit, 89, 32-36.

di Friedberg, O. S. (1993). L'immigration Africaine En Italie: Le Cas Sénégalais. Etudes Internationales, 24(1), 125-140.

Diop, M. (1993). L'immigration Ouest-Africaine En Europe. Études Internationales, 24(1), $111-124$.

Donovon, V. (1988). Réalités Françaises et Conventions Franco-Africaines de Circulation Des Personnes. Peuples Noirs Peuples Africains, 59-62, 149-164.

Ebin, V. (1992). A La Recherche de 'Nouveaux Poissons.' Stratégies Commerciales Mourides Par Temps de Crise. Politique Africaine, 45, 86-99.

Fall, M. (2005). Le Destin Des Africains Noirs En France: Discriminations, Assimilation, Repli Communautaire. Paris: L'Harmattan.

Fasani, F. (2010). The Quest for La Doce Vita? Undocumented Migration in Italy. In A. Triandafyllidou (Ed.), Irregular migration in Europe: Myths and realities (pp. 115-124). Surrey: Ashgate Publishing, Ltd.

Findley, S., Traoré, S., Ouedraogo, D., \& Diarra, S. (1995). Emigration from the Sahel. International Migration, 33(3-4), 469-556.

Finotelli, C., \& Sciortino, G. (2009). The importance of being southern: The making of policies of immigration control in Italy. European Journal of Migration and Law, 11, 119.

Gagrielli, L. (2008). Flux et Contre-Flux Entre l'Espagne et Le Sénégal. L'externalisation Du Contrôle Des Dynamiques Migratoires Vers l'Afrique de l'Ouest. Revue Asylon(S) (3).

Garson, J.-P. (1992). Migration and interdependence: The migration system between France and Africa. In M. M. Kritz, L. L. Lim, \& H. Zlotnik (Eds.), International migration systems: A global approach, international studies in demography. Oxford: Clarendon Press.

GISTI. (2011). Le guide de l'entrée et du séjour des étrangers en France. Paris: la Découverte.

Gokalp, C. (1975). Chronique de l'immigration. Population, 30(4), 889-896.

González-Enríquez, C. (2009). Spain, the cheap model: Irregularity and regularisation as immigration management policies. European Journal of Migration and Law, 11, 139.

González-Enríquez, C. (2010). Spain: Irregularity as a rule. In A. Triandafyllidou (Ed.), Irregular migration in Europe: Myths and realities (pp. 115-124). Surrey: Ashgate Publishing, Ltd.

Gonzalez-Enríquez, C., \& Triandafyllidou, A. (2009). Introduction: Comparing the new hosts of southern Europe. European Journal of Migration and Law, 11, 109.

Helbling, M., \& Kalkum, D. (2017). Migration policy trends in OECD countries. Journal of European Public Policy, O(0), 1-19.

Hollifield, J. F. (1999). Ideas, institutions, and civil society: On the limits of immigration control in France. In G. Brochmann \& T. Hammar (Eds.), Mechanisms of immigration control: A comparative analysis of European regulation policies (pp. 59-95). Oxford: Berg. 
Kaag, M. (2008). Mouride transnational livelihoods at the margins of a European society: The case of residence Prealpino, Brescia, Italy. Journal of Ethnic \& Migration Studies, 34(2), 271-285.

Kabbanji, L. (2013). Towards a global agenda on migration and development? Evidence from Senegal. Population, Space and Place, 19(4), 415-429.

Kane, O. (2011). The homeland is the Arena: Religion, transnationalism, and the integration of Senegalese immigrants in America. Oxford: Oxford University Press.

Kraler, A. (2009). Regularisation: A misguided option or part and parcel of a comprehensive policy response to irregular migration? (Vol. 24). Vienna: IMPCD.

Kritz, M. M., Lim, L. L., \& Zlotnik, H. (1992). International migration systems : A global approach. Oxford/New York: Clarendon Press/Oxford University Press.

Laubenthal, B. (2007). The emergence of pro-regularization movements in Western Europe. International Migration, 45(3), 101-133.

Lessault, D., \& Beauchemin, C. (2009a). Ni invasion, ni exode. Regards statistiques sur les migrations d'Afrique subsaharienne. Revue Européenne des Migrations Internationales, 25(1), 163-194.

Levinson, A. (2005a). Regularisation programmes in France. Oxford: Centre on Migration, Policy and Society, University of Oxford.

Levinson, A. (2005b). Regularisation programmes in Italy. Oxford: Centre on Migration, Policy and Society, University of Oxford.

Levinson, A. (2005c). Regularisation programmes in Spain. Oxford: Centre on Migration, Policy and Society, University of Oxford.

Lochak, D. (1997). Les politiques de l'immigration au prisme de la législation sur les étrangers. In D. Fassin, A. Morice, \& C. Quiminal (Eds.), Les lois de l'inhospitabilité: les politiques de l'immigration à l'épreuve des sans-papiers, Cahiers libres (pp. 29-45). Paris: La Découverte.

Lorenzo, C. P. (2002). Nuestra Errática Normativa Sobre Extranjería: Especial Referencia a Las Regularizaciones y Al Arraigo. Jueces Para La Democracia, 43, 62-71.

Manchuelle, F. (1997). Willing migrants: Soninke labor diasporas, 1848-1960. Athens: Ohio University Press.

Mann, G. (2003). Immigrants and arguments in France and West Africa. Comparative Studies in Society and History, 45(2), 362-385.

Marin, L. (2006). Gêner Pour Exister : L'occupation de l'église Saint-Bernard à Paris En 1996 Par Le 'Premier Collectif' Des sans-Papiers et Ses Conséquences. Migrations Société, 18(104), $121-148$.

Marot, N. (1995). L'évolution des accords franco-africains. Plein droit, 29-30, 96-99.

Massey, D. S., Durand, J., \& Malone, N. J. (2002). Beyond smoke and mirrors: Mexican immigration in an era of economic integration. New York: Russell Sage Foundation.

Mezger Kveder, C. L. (2012). Essays on migration between Senegal and Europe: Migration attempts, investment at origin and returnees' occupational status. Doctoral thesis, University of Sussex.

Mezger, C., \& González-Ferrer, A. (2013). The impol database: A new tool to measure immigration policies in France, Italy and Spain since the 1960s (Vol. 34). Paris: INED.

Miller, M. J. (1994). Towards understanding state capacity to prevent unwanted migration: Employer sanctions enforcement in France, 1975-1990. West European Politics, 17(2), $140-167$.

Pascual de Sans, Angels, J. C., \& Solana, M. S. (2000). Recent immigration to catalonia: Economic character and responses. In R. King, G. Lazaridis, \& C. Tsardanidis (Eds.), Eldorado or fortress?: Migration in Southern Europe (pp. 104-124). New York: St. Martin's Press.

Portes, A. (1978). Introduction: Toward a structural analysis of illegal (undocumented) immigration. International Migration Review, 12(4), 469-484.

Portes, A., \& Böröcz, J. (1989). Contemporary immigration: Theoretical perspectives on its determinants and modes of incorporation. International Migration Review, 23(3), 606-630.

Portes, A., \& Rumbaut, R. (2006). Immigrant America: A portrait (3rd ed., rev.expanded, and update). Berkeley: University of California Press. 
Reyneri, E. (1998). The role of the underground economy in irregular migration to Italy: Cause or effect? Journal of Ethnic and Migration Studies, 24(2), 313.

Reyneri, E. (2003). Immigration and the underground economy in new receiving south European countries: Manifold negative effects, manifold deep-rooted causes. International Review of Sociology, 13(1), 117-143.

Reyneri, E. (2004). Immigrants in a segmented and often undeclared labour market. Journal of Modern Italian Studies, 9(1), 71-93.

Riccio, B. (2001). From 'ethnic group' to 'transnational community'? Senegalese migrants' ambivalent experiences and multiple trajectories. Journal of Ethnic and Migration Studies, 27, 583-599.

Riccio, B. (2008). West African transnationalisms compared: Ghanaians and Senegalese in Italy. Journal of Ethnic \& Migration Studies, 34(2), 217-234.

Schain, M. A. (2008). The politics of immigration in France, Britain, and the United States: A comparative study. Basingstoke: Palgrave Macmillan.

Schoumaker, B., Flahaux, M.-L., Schans, D., Beauchemin, C., Mazzucato, V., \& Sakho, P. (2013). Changing patterns of African migration: A comparative analysis. MAFE Working Paper 18 (Vol. 18). Paris: INED.

Sciortino, G. (1999). Planning in the dark: The evolution of Italian immigration control. In G. Brochmann \& T. Hammar (Eds.), Mechanisms of immigration control: A comparative analysis of European regulation policies (pp. 233-260). Oxford: Berg.

Sciortino, G. (2004). Between phantoms and necessary evils. Some critical points in the study of irregular migrations to Western Europe. In A. Böcker, B. de Hart, \& I. Michalowski (Eds.), IMIS-beiträge: Migration and the regulation of social integration. Osnabrück: Institut für Migrationsforschung und Interkulturelle Studien (IMIS).

Solé, C., \& Parella, S. (2003). The labour market and racial discrimination in Spain. Journal of Ethnic and Migration Studies, 29(1), 121-140.

Spire, A. (2005). Etrangers à la carte: L'administration de l'immigration en France (1945-1975). Paris: Grasset.

Tall, S. M. (2008a). La Migration International Sénégalaise: Des Recrutements de Main-d'oeuvre Aux Pirogues. In M.-C. Diop (Ed.), Le Sénégal Des Migrations: Mobilités, Identités Et Sociétés, Hommes et sociétés (pp. 37-67). Paris: Karthala.

Tapinos, G. (1965). Chronique de l'immigration. Population, 20(4), 675-686.

Terray, E. (2006). Saint-Bernard, Un Bilan : Dix Ans Après. Migrations Société, 18(104), 91-102. Viet, V. (1998). La France immigrée: construction d'une politique, 1914-1997. Paris: Fayard.

Weil, P. (1995). La France et ses étrangers: l'aventure d'une politique de l'immigration de 1938 à nos jours. Paris: Gallimard.

Wihtol de Wenden, C. (2002). Les Sans-Papiers. Regards Sur l'actualité, 277, 43-53.

Open Access This chapter is licensed under the terms of the Creative Commons Attribution 4.0 International License (http://creativecommons.org/licenses/by/4.0/), which permits use, sharing, adaptation, distribution and reproduction in any medium or format, as long as you give appropriate credit to the original author(s) and the source, provide a link to the Creative Commons licence and indicate if changes were made.

The images or other third party material in this chapter are included in the chapter's Creative Commons licence, unless indicated otherwise in a credit line to the material. If material is not included in the chapter's Creative Commons licence and your intended use is not permitted by statutory regulation or exceeds the permitted use, you will need to obtain permission directly from the copyright holder.

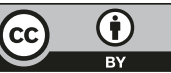




\title{
Chapter 3 \\ Pathways into Irregular Legal Status of Senegalese Migrants France, Italy, and Spain
}

\begin{abstract}
"Illegal" migration is a major concern in most immigrant-receiving countries, yet most policy and much research on the topic is hampered by a lack of data and a misunderstanding of the origins and trajectories of so-called undocumented migrants' legal statuses. Irregular migration is difficult to measure empirically, as it, by definition, escapes the detection of most states' immigration-control bureaucracies. In addition, many surveys have difficulty in sampling what is a mostly hidden population. This lack of data has undoubtedly contributed to an even bigger problem in the study of irregular migration: the conflation of undocumented border crossing with the broader phenomenon of irregularity of legal status. In reality, clandestine border crossing is but one pathway among many into irregular legal status and may not even be the most important one in many countries. Furthermore, immigration policies actively produce these pathways into irregularity through restrictive control mechanisms. A more thorough understanding of the implications of irregularity for both destination societies and for the migrants themselves must therefore study multiple pathways into irregular status.

An approach that is sensitive to the multiplicity of pathways and the role of immigration policies in producing them is especially crucial for understanding irregularity in European destinations. Restrictive immigration-control policies with an emphasis on border control have become the norm in Europe, yet the continent hosts an increasing population of irregular migrants and many countries embark on repeated regularization programs to adjust irregular migrants' legal status. The contradictions inherent in this system may stem from a misapprehension of the nature of irregular migration: research has shown that overstaying after legal entry may be a more important pathway to irregularity than illegal entry, and other policies may facilitate transitions to irregular status while the state pursues regularization programs.
\end{abstract}

The original version of this chapter was revised: Footnote was inserted in the chapter opening page. The correction to this chapter is available at https://doi.org/10.1007/978-3-030-12088-7_7

Portions of Chapter 3 were previously published as: Vickstrom, E. (2014). Pathways into irregular status among Senegalese migrants in Europe. International Migration Review, 48(4), 1062-1099. https://doi.org/10.1111/imre.12154. 
Migration from sub-Saharan Africa in particular has fallen victim to the confusion surrounding the multiplicity and legal production of irregularity. Highly mediatized arrivals of African migrants in leaky fishing boats on European shores in 2006 prompted fears of an "African invasion" and a flurry of restrictive measures to stop it, yet the image of Africans as clandestine migrants both hides the heterogeneity of African migrants' legal situations and obscures the role of European states' immigration policies in producing these situations.

This chapter will analyze the multiple pathways into irregular status for Senegalese migrants. It will argue that irregularity is "legally produced" by immigration policies and will advocate for a conceptualization of legal status that is context-dependent, multidimensional, and longitudinal. The empirical focus will be on the pathways of entry without a visa, overstaying following a legal entry, and "befallen irregularity," or transitioning from regular to irregular legal status. The chapter will analyze the administrative trajectories of Senegalese migrants in France, Italy, and Spain. As Chap. 2 demonstrated, these contexts of reception display variation both within and between countries and over time in their immigration-control mechanisms.

This chapter capitalizes on variation in the forms of irregularity and contexts of reception to ask the following questions: What are the correlates of each of these pathways for Senegalese migrants in France, Italy, and Spain? What role does context of reception play in shaping the pathways of irregularity? Are the pathways linked, i.e., to what extent is irregularity "sticky" or path dependent? Given the diversified profile of Senegalese migrants in these different destinations, what role do various forms of capital play in steering migrants into the various pathways of irregularity? Given the role of policies making regular status contingent on links to family or the formal labor market, what role do these social institutions in the destination country play in structuring these pathways?

The chapter is organized as follows. Section 3.1 reviews the literature on definitions and conceptualizations of migrant irregularity and outlines the empirical pathways into irregular status to be studied. Section 3.2 offers hypotheses: pathways will be structured by contextual variation, and migrants will navigate them with the help of access to forms of capital and links to other social institutions. Section 3.3 describes the data and methods. Section 3.4 presents the chapter's findings: context and forms of capital are more strongly related to pathways that occur more closely in time to the act of crossing a border, while changes in legal status are more closely related to links to social institutions and prior legal statuses. Section 3.5 discusses these results and Sect. 3.6 concludes.

\subsection{Conceptual Approaches to Irregularity}

In addition to these lexical nuances surrounding irregular migration described in Chap. 1, the concept of irregularity is plagued by lack of precision in its categorical and temporal dimensions. Figure 3.1 illustrates the common conceptual problems. Much media, policy, and even academic attention to "irregular" migration actually focuses solely on the legal domain of entry. This may be due in part to the influence 


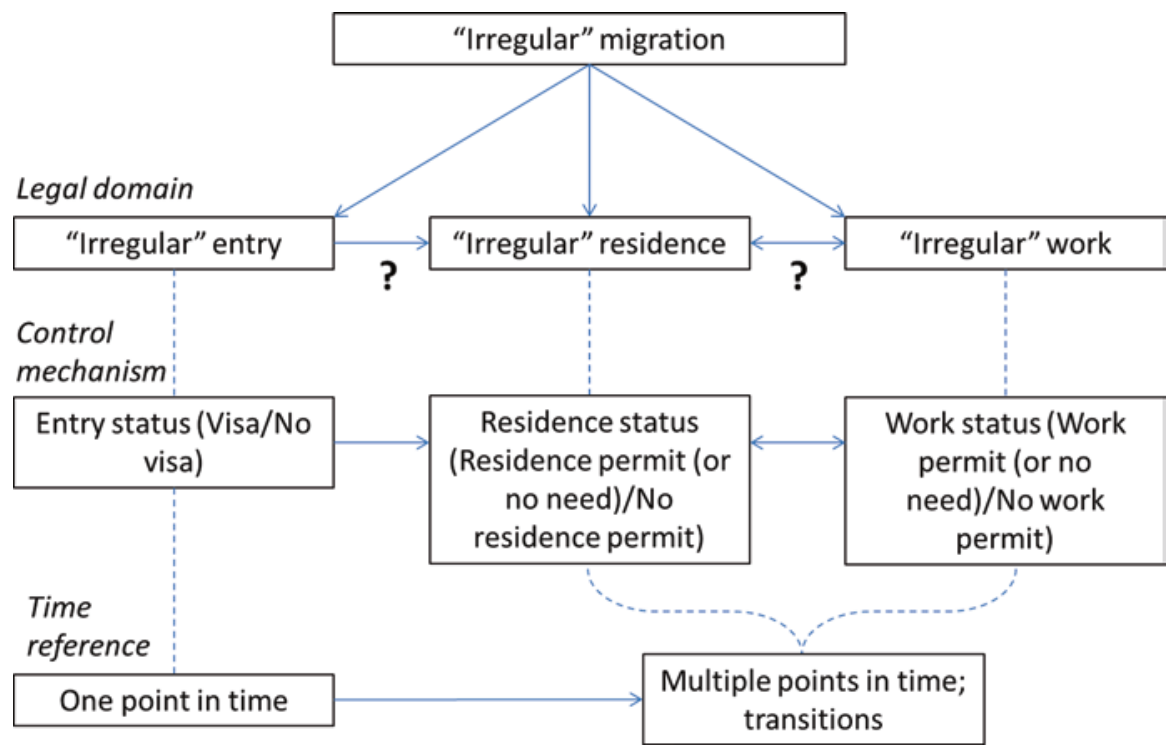

Fig. 3.1 Temporal and categorical complexity of irregularity of legal status

of the U.S. case on perceptions of migration: unauthorized border crossing dominates popular and academic discussions of irregularity in the U.S., and this concept is exported to other contexts. Thus, irregular entry comes to stand for irregular migration, and irregular migrants are those that entered without the required authorization.

In reality, as Fig. 3.1 illustrates, irregularity of legal status is both categorically and temporally more complex. Irregularity can arise not only from the legal domain of entry but also from the legal domains of residence and work; lack of authorization in any of these legal domains can generate irregular status. A proper understanding of irregularity thus must pay attention to multiple legal domains that give rise to categorical complexity of statuses, and also to the mechanisms of immigration control (e.g., documents such as visas and residence permits) that mark migrants as irregular (Brochmann 1999). Furthermore, these multiple legal domains introduce temporal complexity: while irregular entry is defined at one point in time, irregularity of residence and work authorizations is defined at multiple points in time during a migrant's trip. Irregularity as a concept must thus include multiple legal domains and multiple statuses over time.

The categorical and temporal complexity of irregularity illustrated in Fig. 3.1 demonstrates that there are multiple possible pathways into irregular status. Unlike the U.S. context, where irregular entry is the predominant pathway into irregular status, the European context displays a variety of pathways, including unauthorized entry, work in violation of residence conditions, refused asylum application, and irregularity by birth. In addition, "status flows," or transitions between various kinds of statuses are common and include overstaying and befallen irregularity (Düvell 2008, 2011b; Triandafyllidou 2010a). Furthermore, unauthorized border crossing, while it garners a fair share of public and policy attention in Europe, is far from the 
most common pathway into irregular status. Instead, research has shown that overstaying is by far the predominant pathway in most European countries (Finotelli and Sciortino 2013; Kraler 2009), underlining the need for a theoretical and analytical approach that accounts for transitions between legal statuses over time.

\subsubsection{The Legal and Social Production of Irregularity}

While the preceding discussion highlights the multidimensionality of irregularity and the multiple pathways by which migrants access irregular status, many sociological investigations of irregular migration rely on a simple dichotomy of legal status. This is especially true in the United States, and even though the American research tradition has produced useful findings regarding undocumented migration in the US context of reception (Alba and Nee 2003; Borjas and Tienda 1993; Kossoudji and Cobb-Clark 2000; Phillips and Massey 1999; Portes and Rumbaut 2001), scholars have recently begun to argue for more nuanced conceptualizations of irregularity. Research focusing on the social construction of legal-status categories allows both an understanding of how irregularity is produced by historical and sociolegal processes (De Genova 2002) and an expanded conceptualization of irregularity that includes both precarious categories and the dynamism of irregularity over time (Goldring et al. 2009).

Scholars researching the "legal production of illegality" (Goldring et al. 2009) have argued that the notion of irregularity is meaningless without reference to the legal framework in which it is defined: irregular status as a transgression is impossible without the legal framework defining it as such (Sciortino 2004). Research on the production of illegality has shed light on how the seemingly common-sense notion of migrant irregularity is embedded in concrete historical processes and institutions such as laws, policies, labor markets, and other social institutions in destination countries (Calavita 1998; De Genova 2002). Immigration-control policies dictate the channels of legal entry, residence, and work in the destination country and the bureaucratic mechanisms that regulate both these channels and access to other social institutions (such as health care, education, and the possibility of family reunification). These policies and their translation into concrete bureaucratic mechanisms of control (such as visas, residence permits, and work permits) thus set the parameters for the irregular statuses that migrants may experience and the pathways by which they access them. Irregular status thus entails a social relation to a state and its policies and control mechanisms, which themselves have a history within the political process of the state (Sciortino 2004).

Contextual variation is thus crucial in elucidating how different forms of irregularity emerge from different social, legal, and political configurations, especially in a policy context as turbulent as the one in Europe, where frequent changes in immigration legislation and policy are the norm. For example, Düvell (2011a) reports that at least 52 separate laws, codes, decrees, and circulars define French immigration law, and turnover in political leadership has led to 20 immigration laws being 
adopted since 1980 (Wihtol de Wenden 2010). While some of this turbulence in policy has accompanied the transposition of treaties or European Union directives into national laws (as was the case with major Italian and Spanish immigration legislation in the 1990s), individual countries have also fought to maintain sovereignty in much immigration policy making; consequently, there is no commonly accepted definition of irregularity across European countries (Düvell 2011a). This policy turbulence can change the parameters of regularity by making renewal of statuses more difficult or by revoking some forms of status altogether. As a result, migrants may experience categorically complex legal statuses (e.g., legal residence without legal right to work) along with complex trajectories of legal status over time arising from frequent transitions.

The in-depth review of the evolution of immigration policies in France, Italy, and Spain in Chap. 2 highlighted the turbulence of immigration policies in these three countries. Table 3.1 sketches these evolutions and illustrates how policy variation over time and across destinations variation in irregularity over time and across destinations creates different pathways of irregularity. As Chap. 2 showed, France, for example, established a preferential bilateral immigration control regime with Senegal that allowed for free circulation and establishment in each country for nationals of the other. While this was at heart an attempt to maintain French colonial privilege (Donovon 1988), it allowed Senegalese to enter, reside, and live in France without the need for explicit authorization (Marot 1995). Over time, France aligned its bilateral agreements with Senegal with the common immigration-control regime, thus creating irregularity among Senegalese migrants who had not previously been subject to restrictive policies (Lochak 1997).

Table 3.1 also highlights the important variation that exists between destinations at any historical moment. Whereas all three countries have experienced a general evolution towards restrictive immigration-control policies, the features and timing of these policies have not been uniform. France's stiffening of immigration control, for example, occurred at the same time that the southern European countries were dealing with growing foreign-born populations via regularization programs, which may have created new pathways of irregularity in all countries.

The literature on the legal production of irregularity also highlights the role that other social institutions play, either independently or in interaction with immigrationcontrol policies, in creating forms of irregularity. Social institutions are symbolic blueprints that organize people's roles in major areas social life, including the polity and the economy (Portes 2010). In addition to the state's immigration-control apparatuses, social institutions such as the work and the family are likely to have impacts on migrants' legal statuses. State immigration control policies can obviously regulate access to the formal labor market, but the existence of widespread informal employment opportunities may make it easier for migrants to circumvent formal mechanisms of control (Reyneri 1998); the structure of the labor market is thus another contextual factor that can influence the pathways of irregularity. Other social institutions in the destination society can also help create frameworks for irregularity: the ability of migrants with irregular status to access health care and educational systems may make some forms of family irregularity more likely. This 


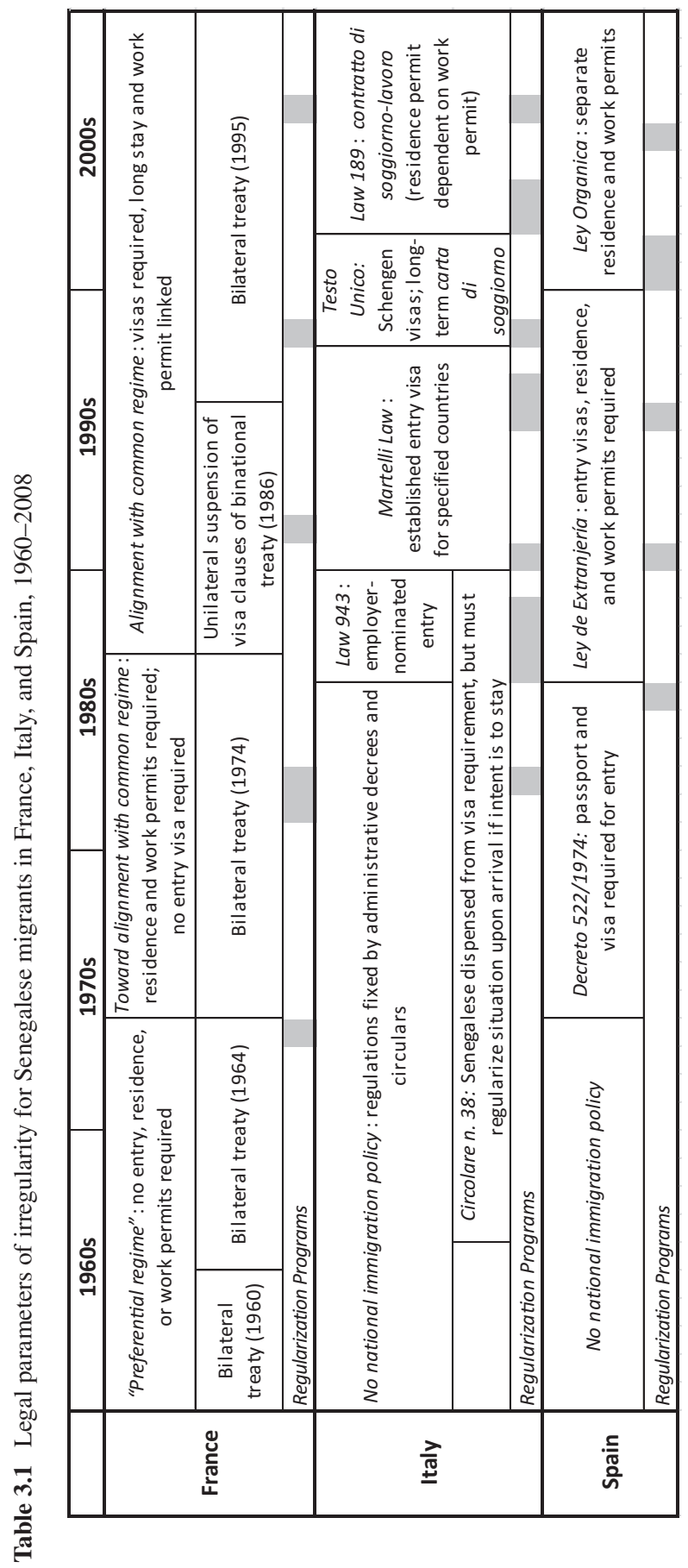


has been suggested in the Spanish case, where legal protection of social rights for migrants with irregular status has made irregular residence and work less risky (González-Enríquez 2009; González-Ferrer 2011a). The social institution of the family itself may also shape pathways of irregularity. Some contexts might promote irregular forms of reunification of family members of migrants, as in Spain where waiting periods imposed on work authorizations for reunified spouses may incentivize bypassing legal reunification channels (González-Ferrer 2011b). Still other policy regimes might facilitate accessing regular status on the basis of "entitlements" in immigration legislation (Kraler 2009) such as familial links, as is the case for parents of minor children born in France since the passage of the Chevènement law in 1998 (Lessault and Beauchemin 2009).

\subsubsection{Multidimensionality of Irregularity}

It is clear from the literature that policies and institutions in the destination society constitute a legal and social framework for the pathways of irregularity. The literature also emphasizes that these frameworks create the conditions for a multiplicity of forms of irregular status, and thus responds to a call for research that acknowledges a continuum of legal statuses and studies transitions between different kinds of legal status (Coutin 1998; Massey and Capoferro 2004; Menjívar 2006).

In disaggregating binary oppositions of regular/irregular status (Donato and Armenta 2011), research has shown that there are a multitude of "precarious" or "liminal" statuses in between the two poles of documented and undocumented and a variety of pathways into these statuses (Düvell 2008; Goldring et al. 2009; Menjívar 2006). Much of this research has focused on non-US contexts of reception where undocumented border crossing is not the only, or even the most important, pathway to irregularity. Goldring et al. (2009, Goldring and Landolt 2011), for example, propose the concept of "precarious legal status," which highlights the multiple forms of impermanent and insecure status that migrants in Canada face. They find that Canadian immigration policy offers several avenues for authorized entry and that migrants often become irregular by losing this authorization once in the country. Their research has also examined transitions between legal statuses and suggests that some pathways of irregularity are more difficult to escape than others (Goldring and Landolt 2011). Canadian immigration-control policy thus produces multiple pathways into irregularity via a multiplicity of precarious statuses. This research echoes findings in other contexts of reception, particularly those of southern Europe where "irregularizing" policies are the norm (Calavita 1998; Schuster 2005).

Other studies offer different typologies but retain the emphasis on complex and multidimensional trajectories of legal status that reflect the contextual specificities of different destinations. Kraler (2009) outlines 13 different "dimensions of illegality" stemming from lack of entry, residence, or work authorization across countries of the European Union. Jandl (2004) employs distinctions between entry, residence, 
and work to generate a typology that includes six categories of clandestine existence and argues that no accurate accounting of illegal migrant flows and stocks can occur without such a fine-grained conceptualization. Ruhs and Anderson (2010) distinguish between compliance, semi-compliance, and non-compliance in examining the labor-market participation of immigrants in the United Kingdom. These studies illustrate that authorizations in different legal domains can combine to create mixed, precarious, semi-irregular, or in-between statuses and that migrants can experience transitions over time between a variety statuses (Düvell 2011a, b). Instead of a bright, stable boundary between regular and irregular status, there is a fuzzy threshold that shifts over time. The categorical multidimensionality and temporal instability of irregular statuses allow an examination of multiple pathways into irregularity over the course of migrants' trajectories.

\subsubsection{Incomplete State Control and Migrant Agency}

This expanded conceptualization of irregularity that is both dynamic and contingent on contextual factors such as legal frameworks and policies allows a more refined understanding of how irregularity is produced. At the same time, much recent research has also insisted on migrants' agency in navigating the laws and policies that set the parameters of their legal statuses. As Sciortino (2004) points out, state claims of control of immigration are never complete: strong policies can fail when the social infrastructure of immigration is robust enough to offer migrants ways of circumventing control mechanisms. This social infrastructure includes individual and collective resources, such as financial, human, social and migration-specific capital (Massey and Espinosa 1997). Research has shown access to these resources to be important at many points in the migration process, including the mode of migration and the legal integration into the destination society (Massey et al. 1998; Massey and Espinosa 1997; Portes and Rumbaut 2006; Singer and Massey 1998).

Migrants can draw on different kinds of resources in their interactions with legal institutions and bureaucracies to influence the process of categorization and documentation. Coutin (1998) argues that migrants, far from being passive in the face of immigration laws and policies, actively interpret and react to such contextual constraints. This engagement allows migrants not only to shape their own legal identities but also to influence the very legal categories that the law presents to them. Spire (2005) demonstrates this agency via the "paper careers" of foreigners in France: migrants were often able to influence their own statuses as a result of bureaucratic agents' institutional autonomy vis-à-vis immigration legislation. Mass movements of migrants can also use political capital to feed back into the policy process and create new legal categories: the sans papiers movement in France in the 1990s at least partially succeeded in forcing legislators to create a legal solution for migrants who were neither regularizable nor deportable (Lochak 1997). While these studies have emphasized the role of forms of capital in accessing regular legal 
status, Sciortino (2004) argues that access to resources is also a precondition to irregular migration, which is an inherently risky and expensive endeavor.

\subsubsection{Pathways into Irregularity}

These conceptual approaches to the production of multidimensional forms of irregularity make the case for important heterogeneity hidden by a binary conceptualization of irregularity, but they also lend themselves to a potentially unending array of typologies of different kinds of legal statuses. This chapter draws on this literature to examine a limited set of three concrete pathways into irregularity for empirical examination. This section reviews the pathways of no-visa ("irregular") entry, overstaying, and befallen irregularity. The discussion will focus on the concrete policy mechanisms of control that define each pathway and the evolution of these control mechanisms in France, Italy, and Spain, both in general and vis-à-vis Senegalese migrants in particular.

\section{Geographic Flows into Irregularity and Mechanisms of External Control: No-Visa Entry}

Entering a country without the proper documentation is a "geographic flow" (Triandafyllidou 2010a) into irregular status: migrants move from one place and enter another without the proper authorization or documentation. While research in the European context has shown that this pathway to irregular status is more limited in its extent than in the US, European countries have invested in restrictive border control and their political discourses around irregular migration focus heavily on undocumented entry (Vollmer 2011).

The main mechanism of control regulating the pathway of irregular entry is the entry visa. In France, visas were nominally required for entry by the 1945 ordinance that organized post-war immigration, but French external control policy was porous until the 1980s. This was particularly true for Senegalese: as a result of a series of bilateral agreements that defined the conditions of entry, residence, and work for Senegalese in France and took precedence over national immigration legislation, Senegalese citizens did not need a visa to enter France between 1960 and 1986 (Marot 1995; Mezger and González-Ferrer 2013). As part of an effort to "close the borders" following economic crises in the 1970s (Lochak 1997), France unilaterally declared entry visas necessary for all non-EU foreigners, including Senegalese, in a governmental circular in 1986 (refer to Chap. 2 for additional details on the evolution of this mechanism of control).

While French policy subsequently lifted visa requirements for nationals of EU and other developed countries, foreigners from many less-developed countries, including Senegal, are still required to have visas to enter France. Despite this evolution towards increased external control, including increased border policing and 
stricter guideline for visa issuance, there are no widely accepted estimates of the number or characteristics of irregular entries to France (Courau 2009). Some research suggests, however, that migrants from France's Mediterranean neighbors (Egypt, Tunisia, Morocco, and Algeria) and former colonies (Senegal, Mali, and Mauritania) are more likely to enter with falsified documents (Wihtol de Wenden 2010).

Irregular entry has long been perceived by northern Europeans to be a more pressing problem in southern Europe, particularly in Italy and Spain. Indeed, both countries are infamous for images of clandestine migrants arriving by boat from the coasts of North or West Africa (Fasani 2010; González-Enríquez 2009, 2010; Pastore et al. 2006) and only developed national-level immigration legislation in the 1980s in response to pressure from other Schengen and EU members concerned about these porous Mediterranean borders. Spain, while having previously established visa requirements via administrative circular or royal decree, instituted Schengen-style visa requirements in an organic law in 1985. Italy allowed Senegalese nationals to enter the country without a visa between 1966 and 1990 (Mezger and González-Ferrer 2013), but abolished this provision in 1990 as part of a general reform of entry policy in accordance with Schengen regulations.

These visa requirements have been part of a general evolution in both southern European countries towards stiffer external controls to combat the perceived threat of irregular entries (Finotelli and Sciortino 2009; González-Enríquez 2009; Sciortino 1999). In reality, unauthorized geographic inflows represent a small proportion of irregular residents in Italy: Fasani (2010) estimates that as few as $4 \%$ of irregular migrants entered without authorization by sea, and as few as $15 \%$ by airport or land borders. Irregular entry to Spain was a significant pathway to irregularity in the 1990s with many clandestine migrants arriving in boats from Morocco, but this pathway has decreased in significance with increased high-tech surveillance of coastlines and bilateral readmission agreements with origin and transit countries (González-Enríquez 2010).

\section{Status Flows into Irregularity and Mechanisms of Internal Control: Overstaying and Befallen Irregularity}

In contrast to geographic flows, status flows involve migrants who are already in a destination country and change legal status (Triandafyllidou 2010a). Status flows towards irregularity can involve overstaying a tourist visa and becoming irregular with regard to work and/or residence; or losing regular residence/work status during a stay in a destination country (otherwise known as "befallen irregularity"). Residence and work permits, which define a foreigner's authorization to reside and work in a destination country, are the main mechanisms of internal control in France, Italy, and Spain; these permits thus define these status-flow pathways of irregularity. Research on irregularity in Europe has demonstrated that status flows are by far the predominant pathway into irregular status (Triandafyllidou 2010a). 
Overstaying — legal entry (with or without a visa and usually for tourism) followed by remaining in the country after the expiration of the visa or entry authorization-represents the most prevalent pathway to irregularity in Europe, and is common in all three countries in this study (Düvell 2011b; Finotelli and Sciortino 2013; Sciortino 2004). While this pathway is often referred to as "visa overstaying," there are many cases in which migrants can be authorized to enter a destination without a formal visa.

In France, many overstayers enter with visas for tourism, studies, family visits, or business and become irregular once their visa/entry authorization has expired and they stay in the country without a valid residence permit (Courau 2009; Wihtol de Wenden 2010). As many of these entry visas are issued under the Schengen rules, they are courte durée (short duration): they allow for a stay in France of only 3 months and do not allow the holder to apply for a residence permit (GISTI 2011). The preferential bilateral regime between France and Senegal also created conditions for overstaying. While Senegalese did not need visas to enter France prior to 1986, "false tourism" was a common strategy for migrating to France: obtaining a work contract in Senegal prior to departing for France was difficult, so many Senegalese entered France without a visa as ostensible tourists and subsequently found work (Bergues 1973). This can only be considered overstaying after 1974, though, which was when France first started requiring Senegalese to obtain residence permits after arrival.

Overstayers are also numerous in Italy: according to the Italian Ministry of Internal Affairs, upwards of $70 \%$ of irregular migrants in Italy between 2000 and 2006 became irregular by overstaying legitimate visas (Fasani 2010). Even though Senegalese migrants were exempt from visa requirements from 1966 to 1990, they were expected to regularize their status after arrival (Mezger and González-Ferrer 2013), leaving them open to irregular status after authorized (although not formally documented) entry. Subsequent Italian immigration laws specified that foreigners had to apply for residence permits within 90 days of arrival, but also made obtaining a residence permit dependent on having a work contract. Those migrants entering on tourist visas thus had little recourse to legitimate regular status once in Italy.

In Spain, overstaying is the main pathway to irregular status, with "false tourism" particularly common for migrants from Spain's former Latin American colonies (González-Enríquez 2010). As in Italy, secure residence status has been linked to employment, but a toleration of irregular work and the provision of some government benefits to irregular migrants has made it possible for migrants to overstay tourist visas (González-Enríquez 2010).

"Befallen irregularity" refers to a situation where migrants lose regular authorization for residence and/or work in a destination and thus fall into irregularity (Triandafyllidou 2010b). In general, this pathway is linked to immigration policies that define residence and work permits of limited duration in an effort to limit legal migration; the expiration of these permits without renewal leads to irregular status. Migrants may not be able to renew their permits for many reasons, but the most frequent obstacle they face is the fact that renewal of residence permits is often linked to proof of legal employment (Triandafyllidou 2010b). Loss of regular status 
may also, seemingly paradoxically, be linked to amnesty or regularization programs through similar employment provisions: migrants who temporarily gain legal status may fall into irregularity if they are unable to fulfill the employment conditions for renewal (Triandafyllidou 2010b). There is also evidence that bureaucratic inefficiencies in processing renewal application can lead to befallen irregularity (Düvell 2011b; Kraler 2009).

Befallen irregularity is a distinct risk for Senegalese migrants under the immigration laws in France, Italy, and Spain. Loss of regular status in France is linked to the limited duration of residence and work permits: most migrants with regular status possess a temporary permit with a maximum duration of 1 year, and they must apply for renewals while still in regular status; a permanent resident permit is only obtainable after years ${ }^{1}$ of continuous regular residence in France (GISTI 2011). Frequent changes in immigration law have been common and tightened renewal procedures have increased the risk of losing regular status (Lochak 1997). The experience of Senegalese sans papiers in France in the 1990s illustrated this risk: the Pasqua law of 1993 made renewal of permanent residence permits more difficult, thus creating many irregular migrants who were nonetheless not deportable because of family ties to France (Lochak 1997).

In Italy, legal employment is a prerequisite for legal residency, thus migrants who are unemployed or who are working in the underground economy can easily fall into fully irregular status because of lack of a formal work contract (Fasani 2010). Spain's approach to dealing with befallen irregularity has evolved over time: prior to 2000, migrants could lose regular status because of bureaucratic delays, but the immigration laws of that year specified that non-response by the administration 3 months after the submission of a renewal application constitutes a renewal of regular status (González-Enríquez 2010). Still, Spain has similar employment provisions to Italy, and many migrants thus lose regular status when they are unable to prove legal employment; this is especially true following extraordinary regularizations, the requirements of which are less strict than for subsequent renewals (González-Enríquez 2010). These inconsistencies in Spanish immigration law have led scholars to conclude that maintaining regular status is almost impossible in Spain (Calavita 1998; Donato and Armenta 2011).

\subsection{Hypotheses}

The geographic and status flows discussed above represent the most important pathways - in either numeric or political terms - into or out of irregular status in France, Italy, and Spain. These pathways are ideal types, and the goal of this chapter is to determine how Senegalese migrants in the main contexts of reception in Europe

\footnotetext{
${ }^{1}$ The required waiting period has varied over time and is currently 5 years (GISTI 2011).
} 
navigate these pathways. The theoretical literature reviewed above offers several hypotheses regarding variation in pathways of irregularity:

Legal and Social Production of Irregularity Variation in immigration-control policies and related social institutions over destinations and time will produce variation in the pathways of irregularity for Senegalese migrants in France, Italy, and Spain.

- Pathways of irregularity will be positively associated with more-recent periods as restrictive immigration-control policies create more pathways to irregular status;

- Migrants in Italy and Spain will experience more forms of irregularity as a result of contextual factors such as later establishment of restrictive immigration policy, longer borders with migrant-sending regions, and greater social tolerance of irregularity;

- Links to other institutions: unemployment may lead to increased risk of irregular status because the renewal of permits is often linked to having a formal work contract, especially in Spain and Italy; spousal or parental connections in the destination country may be associated with decreased probability of experiencing irregular pathways because of provisions that grant legal status for family reunification, being the parent of a minor child, or marrying a citizen of the destination country.

Migrant Capital and Strategic Action Migrants' access to different forms of capital will influence their navigation of pathways of irregularity. In particular, migrants with greater access to human, financial, and social capital will be less likely to experience irregularity, but some forms of migration-specific capital (e.g., previous irregular experience) may increase the probability of other forms of irregularity.

Linkages Between Pathways of Irregularity Forms of irregularity can be temporally interrelated and difficult to escape, and can also provide migrants with skills and knowledge that make subsequent circumvention of immigration-control mechanisms more likely.

\subsection{Data and Methods}

\subsubsection{Sample}

This chapter uses longitudinal life-history data from the Migrations between Africa and Europe (MAFE)-Senegal project, described in detail in Chap. 1. The project collected retrospective data that included complete year-by-year residential and administrative histories of each respondent, along with a host of other sociodemographic data (for more information on MAFE-Senegal methodology, see Beauchemin 2012, 2018). 
The sample for the analysis in this chapter includes individuals who have migrated at least once to Italy, France or Spain while they were greater than 18 (see Chap. 1 for more details on the MAFE sampling and selection scheme). Returned migrants interviewed in Senegal are included if they spent at least a year in at least one of the destination countries. Approximately $14 \%$ of the migrants spent time in multiple destinations within the three main contexts of reception; this chapter considers migration "spells" or individual trips of 1 year or greater by grouping the years that an individual migrant spent in an individual country. This yielded 768 individual- and destination-specific trips that form the basic unit of analysis: 305 in France, 239 in Italy, and 224 in Spain. Descriptive statistics for this sample by country of destination, calculated with probability sampling weights, are available in Table 3.2. These descriptive statistics show important differences between Senegalese migrants in the different contexts of reception. Men account for more than $80 \%$ of the person-years spent by Senegalese migrants in Italy and Spain, but only 59\% in France. Human capital varied across destinations: Senegalese migrants in France tend to be more highly educated with an average of 11 years of formal schooling, compared to 9.8 years in Italy and 6.7 in Spain. More than half of Senegalese migrants in Spain (63\%) and Italy (56\%) reported not speaking the hostcountry language before arrival, while proficiency in French was almost universal prior to arrival in France. Contexts of reception also varied: almost half of migrants in France arrived before 1990, while most in Italy (48\%) and Spain (66\%) arrived after 2000 .

\subsubsection{Legal Status Variables}

Administrative histories provided information on migrants' statuses in the legal domains of entry, residence, and work authorization. Table 3.3 provides the wording of the questions that elicited these statuses and the coding of responses. A dichotomous variable captures entry status as visa $(\mathrm{V})$ or no visa $(\mathrm{NV})$ based on migrants' responses about whether or not they had a visa when they entered the destination country; this variable is thus defined for the year of arrival for each trip. Senegalese nationals did not need visas to enter France between 1960 and 1985 or Italy between 1966 and 1990; migrants who entered those countries during those periods are coded as having a visa since they effectively had an authorized entry status.

For residence and work permits, the questionnaire asked about migrants' authorization in each year in a given destination, and allowed migrants to respond that they had, did not have, or did not need a permit; migrants were additionally able to specify if the work permit was "selective" (i.e., a permit limited to a specific activity). A dichotomous residence authorization variable captures residence permit (RP) or no residence permit (NRP) for each year in the trip, with those migrants who declared not needing a residence permit coded as having authorized residence status (RP) because of their effectively authorized status. A dichotomous variable for work status results in statuses of having/not needing a work permit (WP) and not having 


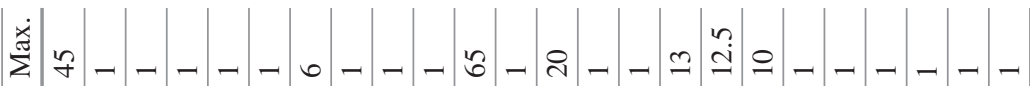
$\dot{\text { g }}$ $\Sigma-00000-000 \ln 000000-000000$

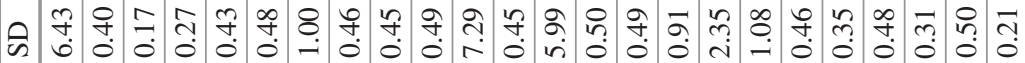

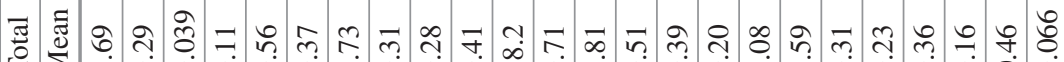

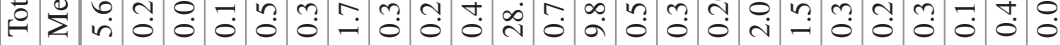

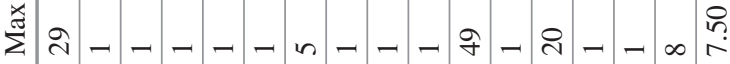

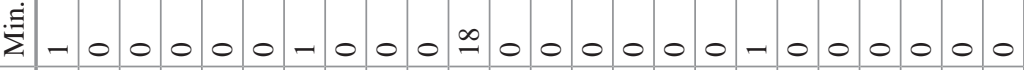

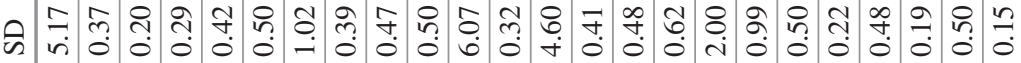

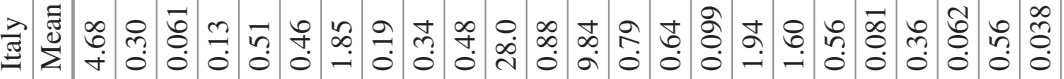

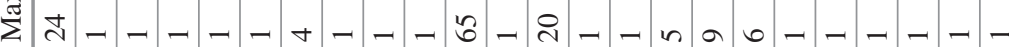
in- $000000-0007000000-000000$

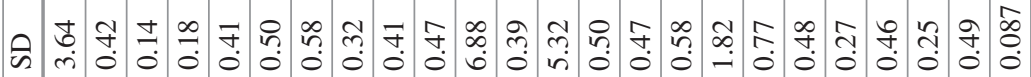

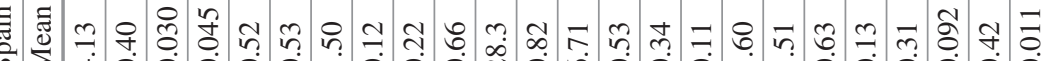

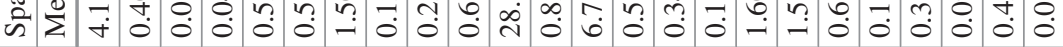

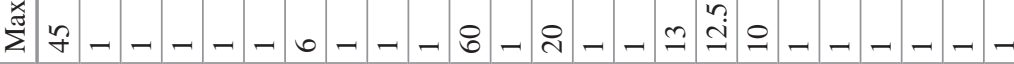
党

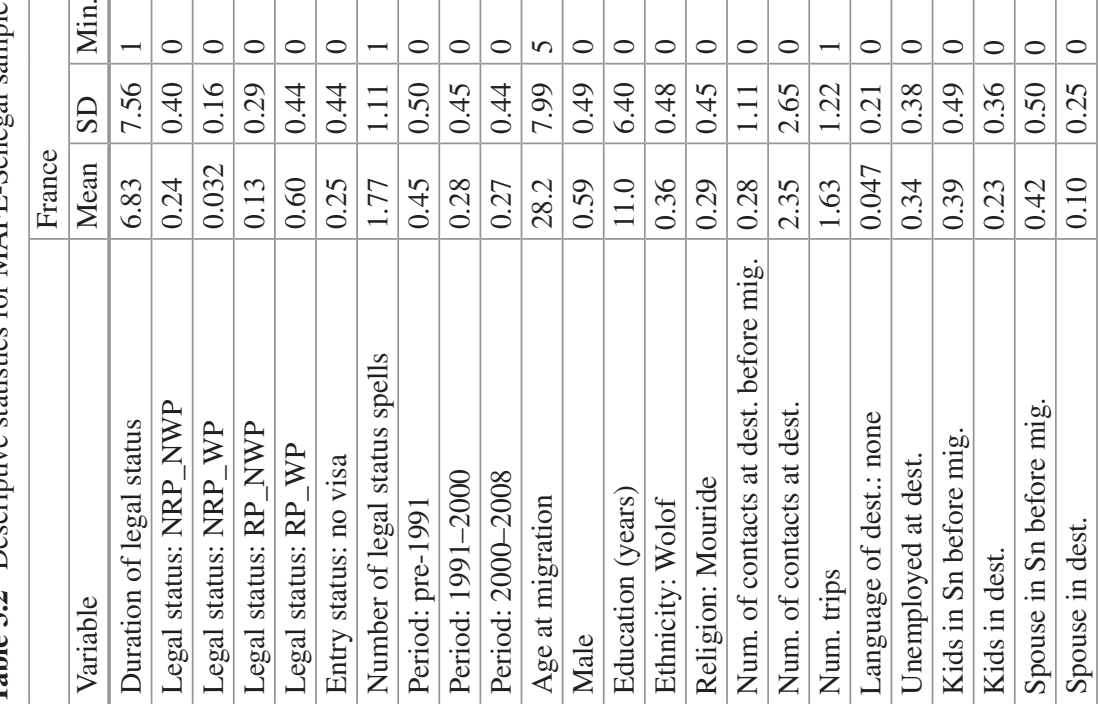




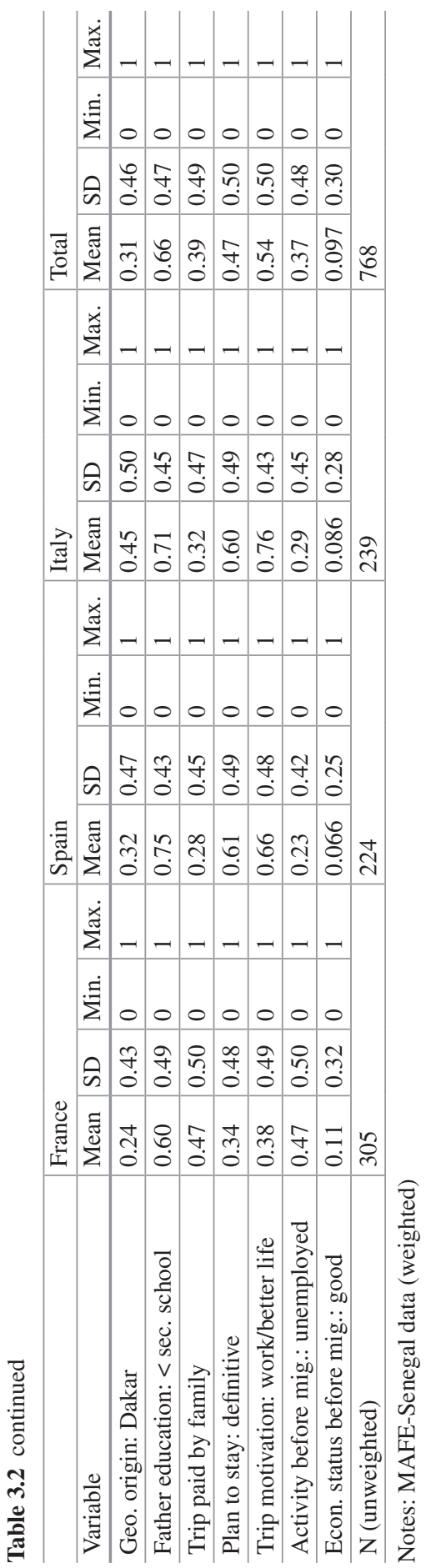


Table 3.3 Legal-status variables and coding, MAFE-Senegal survey

\begin{tabular}{|c|c|c|c|}
\hline $\begin{array}{l}\text { Legal } \\
\text { domain }\end{array}$ & Question & Modalities & Codes \\
\hline \multirow[t]{2}{*}{ Entry } & \multirow{2}{*}{$\begin{array}{l}\text { "When you arrived in [destination } \\
\text { country], did you have a visa? And then? } \\
\text { Did your situation change?" }\end{array}$} & Yes & V: Visa \\
\hline & & No & NV: No visa \\
\hline \multirow[t]{3}{*}{ Residence } & \multirow{3}{*}{$\begin{array}{l}\text { "When you arrived in [destination } \\
\text { country], did you have a residence permit? } \\
\text { And then? Did your situation change?" }\end{array}$} & Yes & \multirow{2}{*}{$\begin{array}{l}\text { RP: Residence permit/ } \\
\text { Did not need }\end{array}$} \\
\hline & & $\begin{array}{l}\text { Did not } \\
\text { need }\end{array}$ & \\
\hline & & No & $\begin{array}{l}\text { NRP: No residence } \\
\text { permit }\end{array}$ \\
\hline \multirow[t]{3}{*}{ Work } & \multirow{3}{*}{$\begin{array}{l}\text { "As for work, when you arrived in } \\
\text { [destination country], did you have a work } \\
\text { permit? And then? Did your situation } \\
\text { change?" }\end{array}$} & Yes & \multirow{2}{*}{$\begin{array}{l}\text { WP: Work permit/special } \\
\text { work permit/did not need } \\
\text { a work permit }\end{array}$} \\
\hline & & $\begin{array}{l}\text { Did not } \\
\text { need }\end{array}$ & \\
\hline & & No & NWP: No work permit \\
\hline
\end{tabular}

a work permit (NWP) for each year in the trip; those migrants who declared a selective work permit were collapsed into the work permit (WP) category.

A composite categorical variable for legal status in each year in the trip combines the indicators of residence and work permits. The combinations of these two forms of authorization were coded as: RP_WP (ego has both residence and work permits), NRP_WP (ego has no residence permit, but a work permit), RP_NWP (ego has a residence permit but no work permit), NRP_NWP (ego has neither a residence permit nor a work permit). This chapter will refer the RP_WP status as "fully regular," while NRP_NWP status is "fully irregular." This chapter uses a variety of terms to describe RP_NWP and NRP_WP statuses, including "precarious," "semicompliant," "semi-irregular," and "mixed." These indicators of legal status serve as both dependent and independent variables reflecting the pathways into irregularity under examination. This basic typology will serve as the main framework for legal status in this and subsequent chapters. The descriptive statistics in Table 3.2 show that migrants experience a variety of post-entry legal statuses, and that these statuses vary by destination. Migrants spend 56\% percent of their person years in fully regular (RP_WP) status across all destinations, and 29\% of their person years in fully irregular (NRP_NRP) status. They spend about $15 \%$ of person-years in semiirregular statuses, with lack of work authorization (RP_NWP) the most common precarious status. Migrants in France are most likely to have both a residence and a work permit (60\% of person-years), while migrants in Spain are most likely to have fully irregular status ( $40 \%$ of person-years). Both kinds of precarious status are more prevalent in Italy than in other destinations. While these descriptive statistics are once again suggestive of systematic differences in irregularity by context, they do not allow examination of disaggregated pathways. 


\subsubsection{Predictor Variables}

The main predictors of interest in the model are indicators of legal and social contexts of reception. Called contextual variables below, these include indicators for destination country (France, Italy, or Spain, with France serving as the reference category), period of arrival (prior to 1991, 1991-1999, and after 2000), and an indicator for whether or not a regularization program took place in the destination in the migrant's year of entry (see Kraler 2009: 37-39 for a comprehensive list of regularization programs).

The second set of predictors indicates a migrant's access to various forms of capital. Migration-specific capital or prior migration experience varies by model and includes prior no-visa entry and previous legal-status category. Human capital includes years of education and competence in the language of the destination. Financial capital includes participation of the family in financing the migration and the migrant's subjective economic status before migration. Social capital is captured by the number of contacts the migrant reports knowing at the destination prior (either prior to arrival or during the year of the outcome, depending on the model).

The third set of predictors captures a migrant's links to social institutions. Dummy variables indicate if the migrant has a spouse or children in the destination country, and a categorical variable indicates the migrant's labor-market status (working, unemployed, or inactive).

Models also include variables capturing individual sociodemographic characteristics, including age at migration and dummy variables for sex (male), ethnicity (Wolof), religion (Mouride), geographic origin in Senegal (Dakar), father's level of education (less than secondary school), migration plans (definitive stay), and migration motivation (work/better life).

\subsubsection{Models}

I model each of the three main pathways into irregular status reviewed above. The model for no-visa entry examines determinants of the dichotomous indicator for starting a trip with a visa and is thus a cross-sectional model at the time of arrival. The model for overstaying uses a cross-sectional multinomial logistic regression to study migrants' residence and work authorizations during the first year of residence in a destination. A final model for befallen irregularity examines transitions over time into fully irregular status and uses discrete-time survival methods. 


\section{No-Visa Entry}

For the model of the pathway of no-visa entry, the dependent variable is the dichotomous variable that indicates whether or not the migrant declared having a visa at the time of entry into the destination country, with values of 1 corresponding to "no visa" and values of 0 corresponding to "visa." All 768 trips and their entry-status indicators are included in the analytic sample for this model. I estimated the following cross-sectional logistic regression:

$$
\ln \left(\frac{\operatorname{Pr}(\text { NoVisa })}{1-\operatorname{Pr}(\text { NoVisa })}\right)=\alpha+X_{1} \beta_{1}+X_{2} \beta_{2}+X_{3} \beta_{3}+X_{4} \beta_{4}+X_{5} \beta_{5}
$$

where $\boldsymbol{X}_{1}$ is a vector of contextual variables, including an interaction between destination and period. $\boldsymbol{X}_{2}$ is a vector of variables indicating prior migration experience: a categorical variable encodes a previous migration spell beginning with or without a visa (with no previous migration spell as the reference category), and a dummy variable indicates whether ego was a returned migrant at the time of the survey. $\boldsymbol{X}_{3}$ is a vector of variables indicating access to forms of capital, with subjective economic status and number of contacts measured before the trip. $\boldsymbol{X}_{\mathbf{4}}$ is a vector of variables representing links to institutions, with employment measured in the year prior to the trip. $\boldsymbol{X}_{\mathbf{5}}$ is a vector of individual variables.

\section{Overstaying}

The analytic sample for the model of the pathway of overstaying again included all 768 trips. The dependent variable is the categorical variable indicating a migrant's legal status (combining indicators of residence and work authorization) during the year of arrival. I estimated the following multinomial logistic regression:

$\ln \left(\frac{\operatorname{Pr}\left(\text { Legal Status }_{i t 1}=i\right)}{\operatorname{Pr}\left(\text { Legal Status }_{t 1}=N R P_{-} N W P\right)}\right)=\alpha+X_{1} \beta_{1}+X_{2} \beta_{2}+X_{3} \beta_{3}+X_{4} \beta_{4}+X_{5} \beta_{5}$

where $i$ indexes the following values of the categorical legal-status variable for the first year at a destination: RP_WP (1), RP_NWP (2), NRP_WP (3); the reference category for this regression is NWP_NWP (4). Predictors are identical to those for Eq. (3.1), with the following exceptions: $\boldsymbol{X}_{2}$ is a dichotomous indicator of entry status during the same trip, coded as " 1 " for entry with a visa and " 0 " for entry without a visa; $\boldsymbol{X}_{\mathbf{3}}$ includes the number of previous migration spells as an indicator of migration-specific capital and measures self-reported economic status during year 1 of the migration spell; and the labor-market indicators in $\boldsymbol{X}_{\mathbf{4}}$ are measured during year 1 of the migration spell. Overstaying is indicated in this model by having entered with a visa and subsequently having a fully irregular legal status during the first year of residence at the destination. 


\section{Befallen Irregularity}

Befallen irregularity is indicated in this model by a transition into fully irregular (NRP_NWP) status. As a dynamic model, it follows individuals over the course of their stay in a destination until they fall into irregular status or are censored. The analytic sample for the model thus includes only those person-years during which a migrant had a fully regular status or a semi-irregular status (i.e., not NRP_NWP). This risk set thus includes 6731 person years. The outcome is a leading dichotomous variable indicating whether the migrant's legal status at time $t+1$ changed to fully irregular (NRP_NWP). I estimated a discrete-time survival model to study the probability of transition to irregular status:

$\ln \left(\frac{\operatorname{Pr}\left(N R P_{-} N W P_{t+1}\right)}{1-\operatorname{Pr}\left(N R P_{-} N W P_{t+1}\right)}\right)=\alpha+X_{1 t} \beta_{1}+X_{2 t} \beta_{2}+X_{3 t} \beta_{3}+X_{4 t} \beta_{4}+X_{5 t} \beta_{5}+X_{6 t} \beta_{6}$

where predictors are the same as in Eq. (3.2), except that $\boldsymbol{X}_{\mathbf{3}}$ now contains a trichotomous variable indicating ego's legal status at time $t$, which can take the values of RP_WP, NRP_WP, or RP_NWP. In addition, variables that are time-varyingnumber of contacts at the same destination, presence of family members at the same destination, and labor-market participation-are measured at time $t$ (a lag of -1 compared to the outcome variable).

\section{Estimation and Presentation of Models}

All models correct standard errors for clustering at the level of the individual, which allows the inclusion of multiple trips per individual. The results of the nonlinear multivariate models are in the form of average marginal effects. In ordinary least squares (OLS) models, regression coefficients represent marginal effects, or the expected change in the outcome variable for a one-unit change in the predictor variable. For nonlinear models, however, the use of a transformation that allows linear modeling of the dependent variable renders interpretation of coefficients less straightforward as the probability of the modeled outcome depends, in part, on the values of the predictors.

While some studies present results for nonlinear models as log-odds or odds ratios, presentation on the same scale as the original data, as is the case with marginal (also called partial) effects, is arguably easier to interpret. For example, computation of marginal effects after a logistic regression model would show how the probability of the outcome changes with a one-unit change for a given predictor variable. Marginal effects also allow for interpretable summaries of interactions between predictors that would be difficult to construct with odds ratios. Average marginal effects are calculated by computing a marginal effect for each case and averaging the value over all cases. If predictors are categorical, the AME represents the expected change in the outcome with a discrete change in the value of the categorical variable (see 
Cameron and Trivedi 2010 for more information on average marginal effects). Standard errors for AMEs are calculated using the delta method. Tables of untransformed coefficient estimates are available in this chapter's Appendix.

\subsection{Results}

\subsubsection{No-Visa Entry}

Descriptive statistics suggest initial support for the hypothesis that context of reception plays an important role in shaping the pathway of no-visa entry. Table 3.2 presents descriptive statistics for the sample under study and shows that $37 \%$ of the migration spells of Senegalese migrants in the MAFE sample started without a visa across all three destination countries. The probability of no-visa entry varies a great deal by destination: while only $25 \%$ of migration spells in France started without a visa, $46 \%$ did so in Italy and more than half (53\%) did so in Spain. Figure 3.2 shows further variation by destination and period. Across all three countries, the probability of no-visa entry has increased since the beginning of the 1990s. No-visa entry was most common during the 1990s in both France and Italy, while it was most prevalent in Spain during the 2000s. This figure also makes it clear that no-visa entry has been more common in all periods in both Italy and Spain than in France.

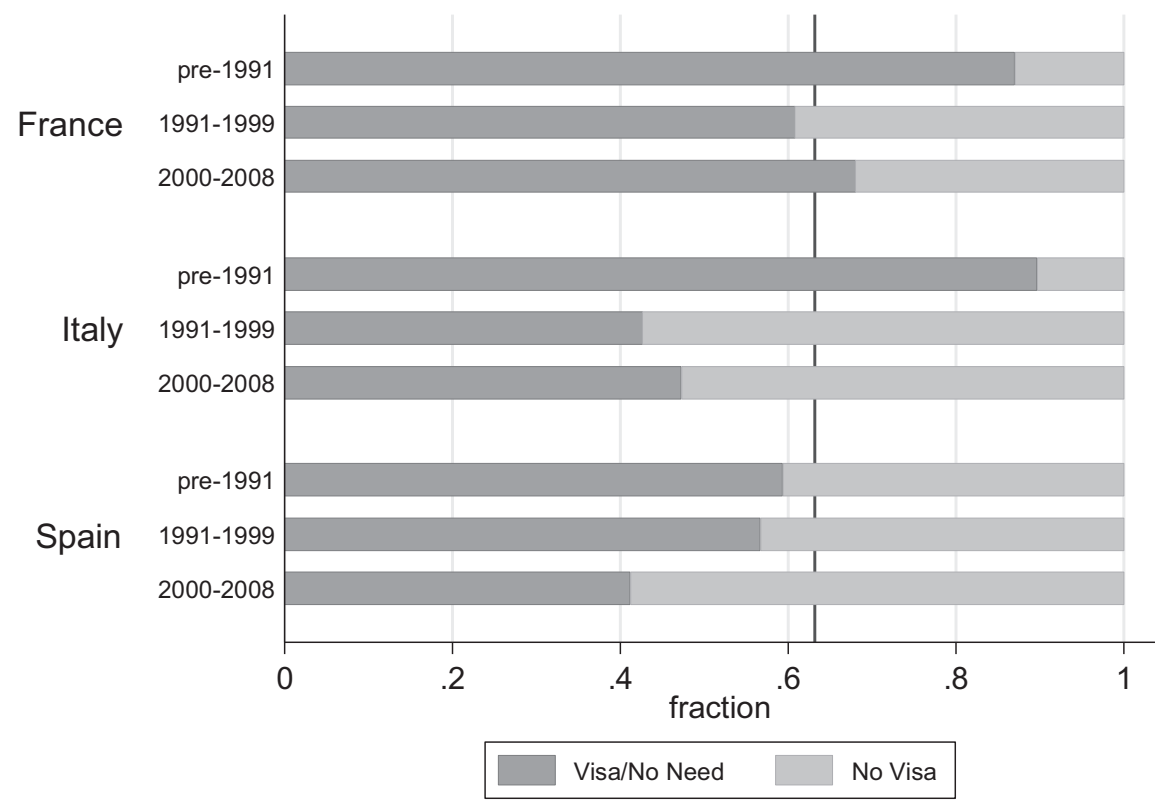

Fig. 3.2 Entry status by destination and period. (Source: MAFE-Senegal. Weighted proportions. Vertical line represents mean of entry with visa) 
Model 1 confirms that no-visa entry is more common in Italy and Spain and in earlier periods. Table 3.4 displays the results of the logistic regression of no-visa entry described by Eq. (3.1) in the form of average marginal effects (AMEs). This model reproduces the main insights of the descriptive statistics regarding context, while adjusting estimates for a host of other contextual and individual variables. Compared to migrants in France, migrants are 14 percentage points more likely to start a migration spell in Spain without a visa, and 18 percentage points more likely to do so in Italy. The relationship between period of arrival and the probability of no-visa entry is even greater: compared to those migration spells starting before 1991, migrants arriving in the 1990s experienced a 24-point increase in the probability of no-visa entry, while for arrivals in the 2000s the increase was 26 points. Perhaps counterintuitively, migrating during the year of a regularization program is negatively associated with entering without a visa (but only at $p<.10$ ).

Because the model includes an interaction between destination and period (which is taken into account when calculating average marginal effects), it is also possible to examine how destination and period work together to shape this pathway. Figure 3.3 shows the predicted probability of no-visa entry for each combination of destination and period and confirms that the probability of no-visa entry to Italy has been almost $60 \%$ since 1991, statistically significantly higher than all periods in France and the pre-1991 period in both Spain and Italy. While there is no statisti-

Table 3.4 Average marginal effects of models for no-visa entry, overstaying, and befallen irregularity

\begin{tabular}{|c|c|c|c|c|c|c|}
\hline \multirow[b]{3}{*}{ Predictor } & \multicolumn{6}{|l|}{ Outcome } \\
\hline & \multicolumn{2}{|l|}{$\begin{array}{l}\text { I. No-visa } \\
\text { entry }^{b}\end{array}$} & \multicolumn{2}{|c|}{ II. Overstay ${ }^{c}$} & \multicolumn{2}{|c|}{$\begin{array}{l}\text { III. Befallen } \\
\text { irreg. }^{d}\end{array}$} \\
\hline & AME & se & AME & se & AME & se \\
\hline \multicolumn{7}{|l|}{ Context } \\
\hline \multicolumn{7}{|l|}{ Period (ref.: pre-1991) } \\
\hline $1991-2000$ & $0.24 * * *$ & 0.044 & $0.10 *$ & 0.046 & 0.0022 & 0.0030 \\
\hline $2000-2008$ & $0.26 * * *$ & 0.047 & $0.21 * * *$ & 0.045 & -0.0018 & 0.0024 \\
\hline \multicolumn{7}{|l|}{ Destination (ref.: France) } \\
\hline Spain & $0.14 * *$ & 0.051 & $0.12 *$ & 0.052 & 0.00063 & 0.0023 \\
\hline Italy & $0.18 * * *$ & 0.050 & 0.083 & 0.054 & 0.0032 & 0.0026 \\
\hline Regularization year (ref.: no) & $-0.067^{+}$ & 0.036 & $0.078 *$ & 0.035 & 0.0022 & 0.0014 \\
\hline \multicolumn{7}{|l|}{ Previous migration experience } \\
\hline \multicolumn{7}{|l|}{ Previous mig. exp.(ref.: none) } \\
\hline Previous mig. exp. w/visa & -0.0056 & 0.075 & - & - & - & - \\
\hline Previous mig. exp. w/out visa & $0.34 * *$ & 0.12 & - & - & - & - \\
\hline Entry status (ref.: no visa) & - & - & $0.11 * *$ & 0.036 & 0.0014 & 0.0014 \\
\hline \multicolumn{7}{|c|}{ Origin legal status (ref.: RP_NWP) } \\
\hline Mixed (NRP_WP) & - & - & - & - & 0.0012 & 0.0057 \\
\hline Fully regular (RP_WP) & - & - & - & - & $-0.0061 *$ & 0.0030 \\
\hline Return migrant (ref.: no) & $0.20 * *$ & 0.065 & $-0.14 *$ & 0.062 & 0.00027 & 0.0030 \\
\hline
\end{tabular}


Table 3.4 (continued)

\begin{tabular}{|c|c|c|c|c|c|c|}
\hline \multirow[b]{3}{*}{ Predictor } & \multicolumn{6}{|l|}{ Outcome } \\
\hline & \multicolumn{2}{|l|}{$\begin{array}{l}\text { I. No-visa } \\
\text { entry }\end{array}$} & \multicolumn{2}{|c|}{ II. Overstay ${ }^{c}$} & \multicolumn{2}{|c|}{$\begin{array}{l}\text { III. Befallen } \\
\text { irreg. }^{d}\end{array}$} \\
\hline & AME & se & AME & se & AME & se \\
\hline \multicolumn{7}{|l|}{ Forms of capital } \\
\hline Years of education & $-0.008 *$ & 0.003 & $-.01 * * *$ & 0.003 & 0.00011 & 0.0002 \\
\hline Speaks language of dest. (ref.: yes) & $-0.066^{+}$ & 0.036 & 0.012 & 0.041 & $-0.0029^{+}$ & 0.0017 \\
\hline Financial help of family (ref.: no) & -0.052 & 0.039 & $-0.084 *$ & 0.038 & 0.00046 & 0.0022 \\
\hline $\begin{array}{l}\text { Self-reported economic status (ref.: } \\
\text { bad) }\end{array}$ & $-0.13^{*}$ & 0.057 & 0.052 & 0.086 & -0.0027 & 0.0023 \\
\hline Number of contacts at dest. & 0.0025 & 0.016 & -0.014 & 0.009 & -0.00041 & 0.0007 \\
\hline Number of trips & - & - & $-0.1 * * *$ & 0.021 & $0.0012 *$ & 0.0005 \\
\hline \multicolumn{7}{|l|}{ Links to social institutions } \\
\hline Kids at dest. (ref.: no) ${ }^{\mathrm{a}}$ & -0.019 & 0.054 & $-0.14 *$ & 0.060 & -0.0027 & 0.0020 \\
\hline Spouse at dest. (ref.: no) ${ }^{\mathrm{a}}$ & 0.022 & 0.049 & $-0.13 * *$ & 0.047 & 0.00049 & 0.0025 \\
\hline \multicolumn{7}{|l|}{ Economic activity (ref.: inactive) } \\
\hline Unemployed $^{\mathrm{a}}$ & 0.028 & 0.068 & $0.19 *$ & 0.076 & 0 & . \\
\hline Employed $^{\mathrm{a}}$ & -0.039 & 0.041 & $0.11 *$ & 0.047 & $-0.01 * * *$ & 0.0017 \\
\hline Definitive plans to stay (ref.: no) & $0.059^{+}$ & 0.034 & 0.011 & 0.033 & 0.00017 & 0.0018 \\
\hline $\begin{array}{l}\text { Migration motive: work (ref.: not } \\
\text { work) }\end{array}$ & -0.021 & 0.036 & 0.026 & 0.038 & -0.00029 & 0.0020 \\
\hline \multicolumn{7}{|l|}{$\begin{array}{l}\text { Individual sociodemographic } \\
\text { characteristics }\end{array}$} \\
\hline Age at migration & $0.0056^{*}$ & 0.002 & -0.0036 & 0.003 & 0.000052 & 0.0001 \\
\hline Sex: male (ref.: female) & 0.046 & 0.044 & -0.066 & 0.041 & 0.00029 & 0.0025 \\
\hline Ethnicity: Wolof (ref.: other) & 0.031 & 0.035 & 0.043 & 0.037 & $-0.0045^{*}$ & 0.0020 \\
\hline Religion: Mouride (ref.: other) & $0.13 * * *$ & 0.036 & 0.062 & 0.038 & -0.0017 & 0.0017 \\
\hline Geographic origin: Dakar (ref.: other) & -0.019 & 0.035 & $0.087 *$ & 0.035 & $0.0046^{+}$ & 0.0027 \\
\hline $\begin{array}{l}\text { Father's education: < secondary (ref.: } \\
>\text { ) }\end{array}$ & -0.040 & 0.035 & 0.053 & 0.036 & 0.00020 & 0.0018 \\
\hline Status duration (years) & - & - & - & - & $-0.001^{*}$ & 0.0004 \\
\hline Num. of status spells & - & - & - & - & $-0.0080^{*}$ & 0.0031 \\
\hline $\mathrm{N}$ & \multicolumn{2}{|l|}{763} & \multicolumn{2}{|l|}{763} & \multicolumn{2}{|l|}{6731} \\
\hline Log likelihood & \multicolumn{2}{|l|}{-395.37} & \multicolumn{2}{|l|}{-690.40} & \multicolumn{2}{|l|}{-1577.11} \\
\hline Pseudo $\mathrm{R}^{2}$ & \multicolumn{2}{|l|}{0.2045} & \multicolumn{2}{|l|}{0.2262} & \multicolumn{2}{|l|}{0.2290} \\
\hline
\end{tabular}

Source: MAFE-Senegal

Notes: ${ }^{+} p<0.1,{ }^{*} p<0.05,{ }^{* *} p<0.01,{ }^{* * *} p<0.001$. Average marginal effects displayed. Models include interaction between destination and period

${ }^{a}$ Variable measured prior to migration for model I

${ }^{b}$ Logistic regression of no-visa entry

${ }^{\mathrm{c}}$ Multinomial logistic regression of four legal-status categories

${ }^{\mathrm{d}}$ Discrete-time survival model (logistic regression) of status change to NRP_NWP (fully irregular) 


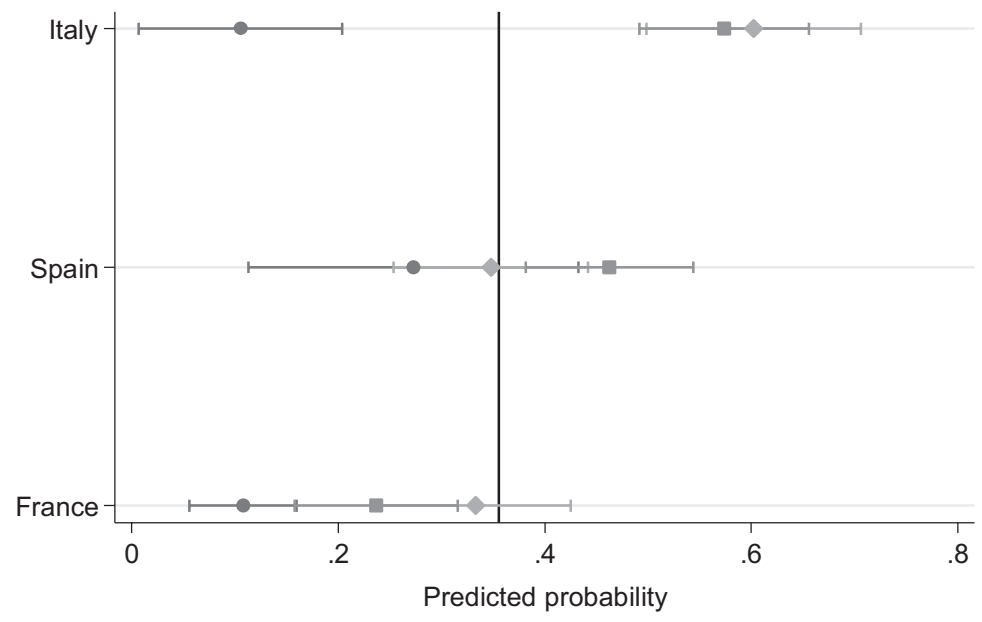

- pre-1991 1991-1999 2000-2008

Fig. 3.3 Predictive margins of no-visa entry, by destination and period, with $95 \%$ confidence intervals. (Source: MAFE-Senegal. Vertical line represents average predictive margin)

cally significant difference in the predicted probability of no-visa entry in Spain between periods, the pattern found in the descriptive statistics of a monotonic increase over time remains. No-visa entry seemed to peak in France in the 1990s, but both later periods have predicted probabilities of no-visa entry that are statistically significantly higher than the pre-1991 period. It is thus clear that context, both in terms of destination and period of arrival, plays an important role in shaping access to the no-visa pathway to irregularity, and that this pathway is more common in Southern Europe (especially Italy).

While the indicators for destination country and period could capture the effects of a number of factors, such as economic conditions, there is reason to suspect that the increase in entry without a visa over time and in southern Europe is related principally to the evolution towards increased restrictiveness in the legal context. France's immigration policy evolved in a restrictive direction, and the southern European countries went from a complete lack of a national-level immigration framework to a system designed to plug perceived holes in Mediterranean borders. The increase in no-visa entry over time, especially in southern Europe, is indicative of the creation of this pathway of irregularity by immigration policy.

In addition to shedding light on the contextual factors shaping no-visa entry, Model I of Table 3.4 suggests other factors associated with this pathway to irregularity. There is a strong link to previous irregular experience: having entered a destination without a visa during a previous migration spell is associated with an increase in the probability of no-visa entry of 34 points. Indeed, this is the strongest predictor of no-visa entry in terms of magnitude, and thus offers evidence of the path-dependence of irregular status. This effect can also be interpreted as a form of 
migration-specific capital: migrants draw on knowledge and skills gained on previous trips starting with an unauthorized entry to make future unauthorized entry more likely. Returned migrants are also 20 percentage points more likely to have started their trips without a visa.

In addition to migration-specific capital, other forms of capital are also associated with no-visa entry as hypothesized. Financial capital plays a role in irregular entry: while there is no association between family resources, social class (as measured by father's education), or employment prior to migration with no-visa entry, good subjective economic status is associated with a lower probability of no-visa entry. This suggests that visas are selective of the economically successful, but research has also shown that resources of many kinds are necessary for irregular entry (for travel, passeur fees, etc.). There is also evidence of other forms of capital: belonging to the Mouride Islamic brotherhood is associated with an increase of 13 points in the probability of migrating without a visa; this brotherhood is well known for facilitating the migration of its members by providing social and economic support (Kaag 2008; Riccio 2008), and this finding suggests that its members can draw on the social capital in this network for resources to circumvent entry restrictions. There is no evidence in the model of associations between links to family in destination and the probability of no-visa entry, which indicates those migrants who have families in the destination country do not attempt to rejoin them via this pathway and suggests that families wishing to reunify have access to channels that permit legal entry.

\subsubsection{Pathway: Overstaying}

Results for overstaying suggest once again the importance of context and access to forms of capital for this pathway to irregularity, and also show the importance of links to institutions at the destination. Figure 3.4 shows the first legal status of Senegalese migrants' migration spells by both destination and entry status. This figure suggests that migrants in France are more likely to transition to fully regular (RP_WP) status following arrival than migrants in Italy or Spain; the proportion of migrants transitioning to this status in France is close to half regardless of entry status, while it is much lower in both Spain and Italy. Most of this difference seems to be explained by higher probabilities of transition to fully irregular first status (NRP_NWP) in the southern European countries. In addition, a higher proportion of migrants entering with a visa transition to fully irregular first status in Italy and Spain than in France. Indeed, in France, entering without a visa seems to be associated with increased probability of transitioning to irregular status, indicating that irregular entry is more closely associated with irregular status in the first year. Thus, irregular first status is higher overall in the southern European countries and in particular for those migrants who enter with a visa, suggestive of overstaying in Italy and Spain. 


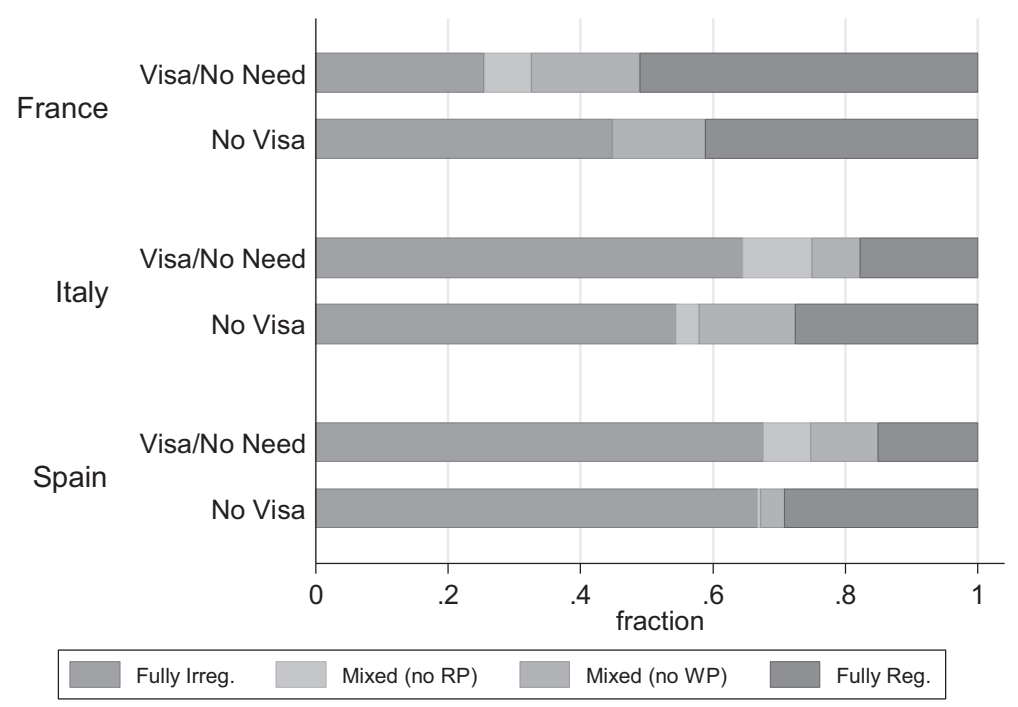

Fig. 3.4 First legal status by destination and entry status. (Source: MAFE-Senegal. Weighted proportions)

Table 3.4 shows selected results for the multinomial logistic regression of model 2. While the model includes all four legal-status categories in the dependent variable, ${ }^{2}$ Table 3.4 only displays average marginal effects for the probability of fully irregular (NRP_NWP) first status as the pathway of interest concerns transition from having an entry visa to fully irregular status. The model confirms the descriptive results: on average, entering with a visa is associated with an increase of 11 percentage points in the probability of having a fully irregular first legal status. This result, while seemingly counterintuitive, suggests that irregularity is not merely the result of irregular entry and, conversely, that illegal entry does not lead to permanent irregularity.

The probability of irregular status during the year of arrival also varies by destination: the model confirms that irregular first status is more common in southern Europe: the probability of first-status irregularity is 14 and 11 percentage points higher in Italy and Spain, respectively, than France. The effects of period of arrival are also evident: arrival in the 1990s is associated with an increase of 11 percentage points in the probability of transition to irregular first status, while the increase is 26 points for the 2000s. Arriving during the year of regularization is positively associated with the probability of having irregular status upon arrival, suggesting that Senegalese migrants may have sought out destinations for the regularization opportunities they offered at certain points in time.

\footnotetext{
${ }^{2}$ While "NRP_NWP" was identified as the base category for modeling purposes, it is possible to calculate the average marginal effects related to the probability of this category since the probabilities of all categories must sum to unity.
} 


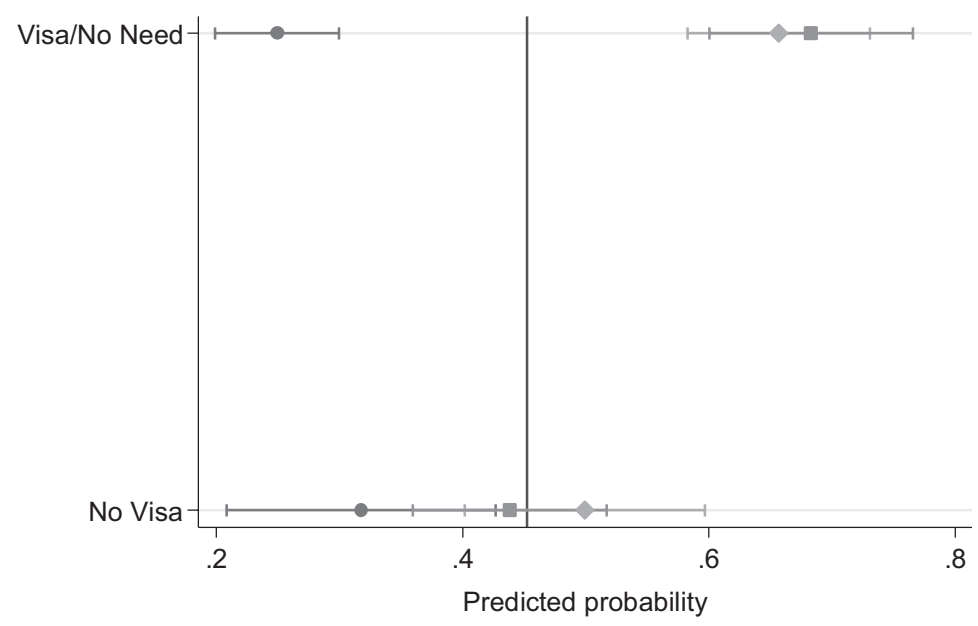

- France Spain Italy

Fig. 3.5 Predictive margins of NRP_NWP first status, by entry status and destination, with 95\% confidence intervals. (Source: MAFE-Senegal. Vertical line represents average predictive margin)

The model allows an examination of how the effect of entering with a visa varies by context. Figure 3.5 displays the predicted probabilities of NRP_NWP first status by entry status and destination and shows that the probability of transitioning to irregular status after arrival is higher for migrants with visas in Italy and Spain than in France. Conversely, there is no statistically significant difference in the probability of this transition between the three countries for migrants entering without visas. The positive effect of entering with a visa on the probability of being irregular during the year of arrival is thus concentrated in the southern European destinations, and the effect is strongest in Italy, as Fig. 3.6 shows. There is thus ample evidence that this pathway is produced by variation in context, both geographically and over time.

Social, migration-specific, and financial forms of capital are negatively associated with becoming irregular during the first year of residence. As Model II of Table 3.4 shows, the probability of first-status irregularity decreases with the number of contacts at destination, the number of previous migration spells, the financial participation of the migrants' family, and the migrants' self-reported economic status before the trip. Access to a variety of resources thus protects against first-status irregularity. Having children in the destination country is also associated with reduced probability of first-status irregularity, as is having a spouse at destination (although the effect is not statistically significant), indicating that family links at destination help protect migrants from irregularity. Returned migrants are also less likely to have been in fully irregular status during their year of arrival despite having a higher probability of having entered without a visa. Other factors are positively associated with this pathway: being from Dakar and migrating for work/a better life 


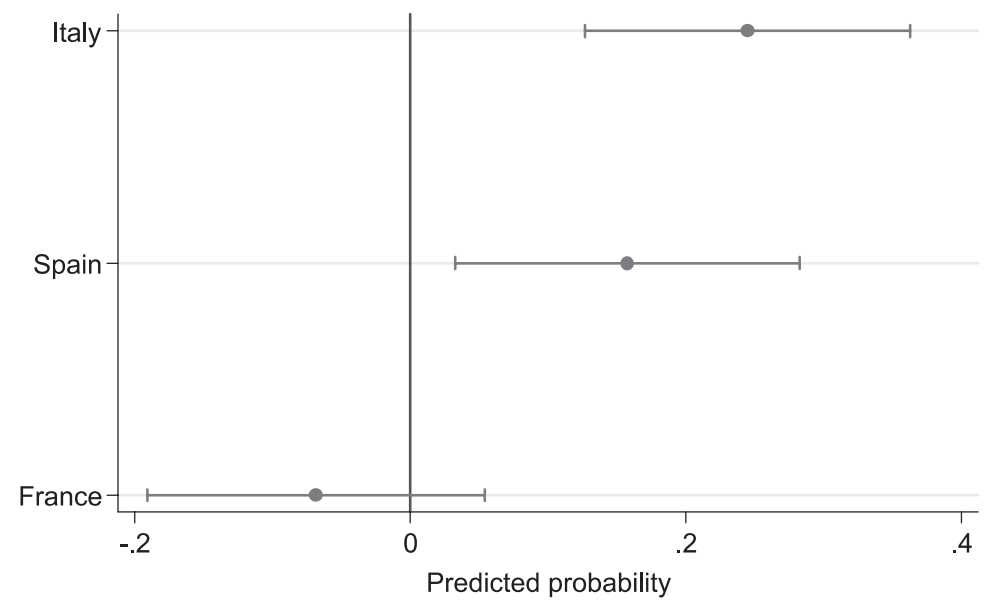

Fig. 3.6 Average marginal effect of entry with visa on NRP_NWP first status, with 95\% confidence intervals. (Source: MAFE-Senegal)

are positively associated with the probability of first-status irregularity, and belonging to the Mouride brotherhood is marginally positively associated with this outcome $(p=0.051)$.

\subsubsection{Pathway: Befallen Irregularity}

Unlike the pathways of no-visa entry and overstaying, the determinants of the pathway of befallen irregularity are prior legal status, while there is little evidence of contextual variation or relationship to forms of capital. The overall probability of transition from fully regular or semi-irregular statuses to fully irregular status is quite low: a basic life table (not reported) indicates that less than $4 \%$ of migrants at risk for this transition ever actually experience it. This provides descriptive evidence that migrants with fully regular or semi-irregular statuses are unlikely to transition to fully irregular status. This finding is borne out by the graphical transition matrix of Fig. 3.7, which shows that transitions into full irregularity are rare among migrants who change status; indeed, the most common transitions seem to be into fully regular status (RP_WP).

Model III of Table 3.4 displays results from the discrete-time survival analysis of befallen irregularity, and indicates that origin legal status - the status from which a migrant may transition into fully irregular status - is one of the strongest sets of predictors in the model. Migrants with fully regular status are less likely to transition to irregular status than those with either semi-irregular status. Figure 3.8 depicts predicted probabilities of befallen irregularity and shows that the predicted probability for fully regular migrants of transitioning to fully irregular status is less than half of the average predicted probability for migrants with semi-irregular statuses. 


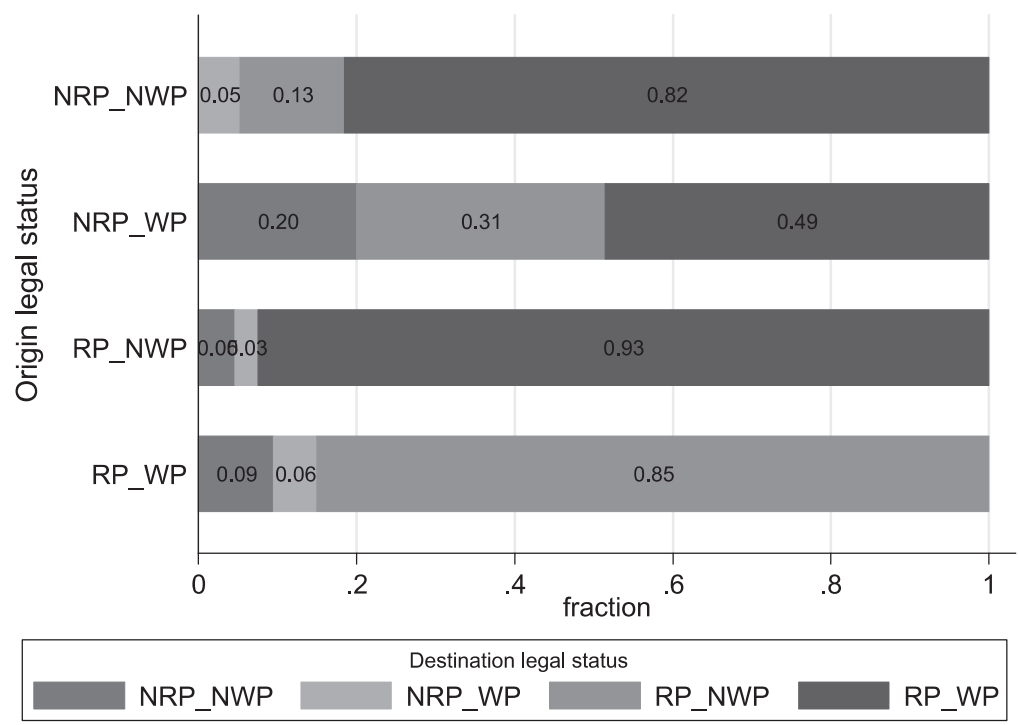

Fig. 3.7 Legal status transitions. (Source: MAFE-Senegal. Horizontal line represents average predictive margin)

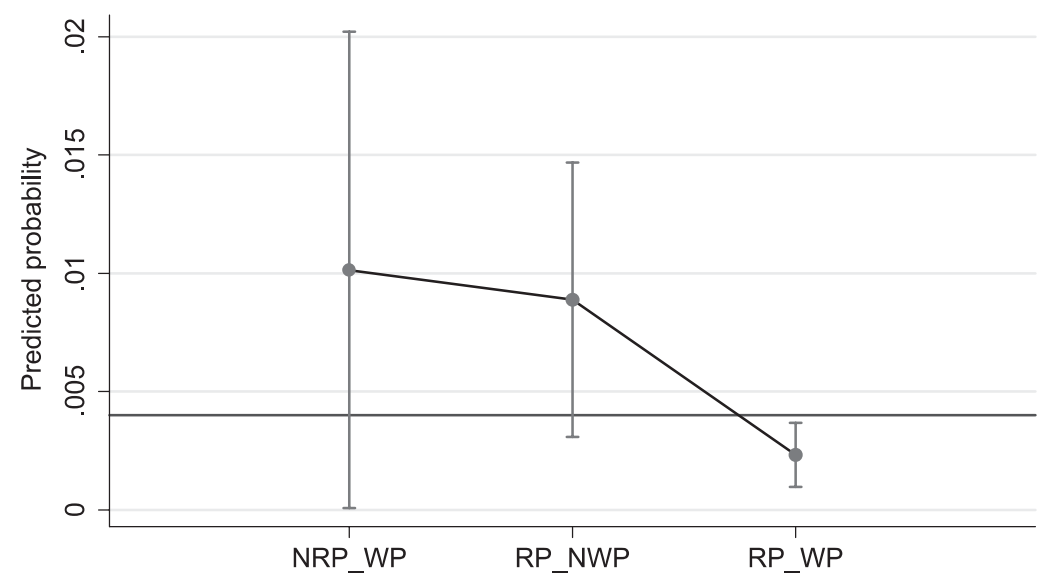

Source: MAFE - Senegal. Horizontal line represents average predictive margin.

Fig. 3.8 Predictive margins of transition to NRP_NWP, by prior status, with 95\% confidence intervals

There is thus evidence that fully regular status is quite "sticky," i.e., transitions from it into full irregularity are rare. The low (close to $1 \%$ ) predicted probabilities of befallen irregularity for migrants with semi-irregular legal status suggest that transitions into full irregularity are rare from any prior status. 
Unlike previous pathways, context—destination and period of arrival-does not have a statistically significant relationship with befallen irregularity. While origin legal status is strongly related to the probability of transitioning to fully irregular status, entry status is not. Forms of capital are also not significantly related to this transition, with the exception of the number of previous migrations. The positive relationship between number of migrations and the probability of befallen irregularity suggests that previous migration experience may help navigate a destination's institutions and labor market in an irregular status. Among predictors indicating links to destination institutions, only the employment variable is associated with befallen irregularity: being unemployed is negatively related to this transition. Surprisingly, neither having a spouse nor having children in the same destination is protective of falling into irregularity.

Among the remaining predictors, the duration of the legal status before transition, the number of legal-status spells, and Wolof ethnicity are all negatively related to the probability of transitioning to fully irregular status. The duration and number of spells variables indicate that transitions to irregularity, if they occur, happen early in migrants' stay in a destination country, and that experiencing multiple kinds of legal status help migrants avoid fully irregular status. While indicators of context are not statistically significantly related to befallen irregularity, the ethnicity and employment variables are suggestive of contextual effects. Non-Wolof migrants are concentrated in France, and literature suggests they are mainly Soninké from earlier migration flows (Timera and Garnier 2010); this may be indicative of transitions to irregularity under France's somewhat lax immigration regime of the 1960s and early 1970s.

\subsection{Discussion}

Literature on the pathways into irregular legal status has drawn on insights from research on the "legal production of illegality" to insist on the importance of context in setting the parameters that shape the pathways in a given context of reception. This literature has also challenged dominant binary conceptualizations of legal status by examining multiple forms of irregularity and changes in these often-fuzzy statuses over time. This chapter has drawn on these insights to study three pathways into irregular status among Senegalese migrants in France, Italy, and Spain: no-visa entry, overstaying, and befallen irregularity.

In keeping with the literature on the legal production of illegality, this chapter hypothesized that context — both destination country and period-would play a preponderant role in structuring all of the pathways by setting the legal parameters of irregularity. The results, however, showed that context was more important in structuring pathways that occur early in the migrant's trajectory-no-visa entry and overstaying-than subsequent transitions to irregularity. The pathway of no-visa entry was more likely in Spain and Italy than in France, and the prevalence of no-visa entry rose monotonically over time in the southern European countries, while it peaked in 
France in the 1990s. Context likewise had a strong association with the pathway of overstaying: irregular first status more likely for those entering with visa in Italy and Spain than in France, with the strongest relationship in Italy. The probability of irregular first status also increased monotonically over time by period of arrival.

The effects of context were less clear, however, for changes in legal status once migrants were established at the destination. There was virtually no direct relationship between context and befallen irregularity. This contrasts with research that shows that status transitions are common in southern Europe (Fasani 2010; González-Enríquez 2010) or with the review in Chap. 2 that outlines the multiplication of various pathways into irregularity. These findings suggest that context is more important in shaping the pathways that occur closer in time to the act of crossing a border.

The political discourses (Vollmer 2011) and resources devoted to border control in all three destinations (Courau 2009; Fasani 2010; González-Enríquez 2010) may help make sense of the stronger relationship that contextual indicators have to these earlier pathways. The policy and legal parameters surrounding entry have varied the most between destinations and over time, with a pronounced evolution towards restrictiveness and a resultant externalization of control mechanisms (Brochmann 1999). Increased border surveillance and tighter visa requirements are common responses in France, Italy, and Spain to political pressures at both the national (Freedman 2004; González-Enríquez 2009; Sciortino 1999) and EU level (Finotelli and Sciortino 2009) to appear "in control" of migration.

As many studies of immigration control have shown, though, policies often have unintended consequences (Brochmann 1999). Increased external controls have created irregular entry flows directly by definition, and have, as a result, transformed regular flows into irregular ones. At the same time, these restrictive entry policies will make migrants less likely to depart once in destination because of increased risk and costs of entry; this may favor the production of irregularity in the first legal status at destination. These dynamics resemble features of the Mexico-United States migration system, where increased border control has done little to prevent undocumented migration as measured by apprehension probabilities and has instead led to longer stays of undocumented migrants because of the increased price and risk of undocumented border crossing (Massey et al. 2002, 2016). The increases of no-visa entry and overstaying thus underline that irregularity is a manufactured state rather than a characteristic of the migrants themselves.

In contrast, policy attention given to border control and controlling geographic flows has often meant a relative negligence of frameworks governing migrants' integration once at destination (Finotelli and Sciortino 2009; Freedman 2004; GonzálezEnríquez 2009; Sciortino 1999). This is borne out by the MAFE-Senegal data: changes of status are somewhat rare (less than $50 \%$ of the sample changed status), and they are not tightly linked to context. This suggests that those transitions that do take place may not be systematically produced by sociolegal frameworks that vary over destination and time, but instead are embedded in logics of integration that have not been major policy concerns, perhaps because of general acceptance or ignorance of migrants' irregular status once they are established at a destination. 
This chapter also drew on the literature on expanded conceptualizations of irregularity to hypothesize that there would be systematic links between various pathways of irregularity. Prior no-visa entry was strongly predictive of current no-visa entry. Previous undocumented border crossing could thus be considered as a form of migration-specific capital that makes future undocumented trips more likely, a finding that is common in the US context (Massey and Espinosa 1997). Entering with a visa on the current trip, on the other hand, was strongly predictive of transition to fully irregular first legal status in Italy and Spain. For these migrants, a visa may simply be a springboard into informal employment in societies that have a higher tolerance of irregularity; in France, on the other hand, even migrants with visas have a fairly low predicted probability of transitioning to fully irregular status, implying that there may be more stable paths to regularity or more intolerance of irregularity there. In contrast, there was no association between entry status and subsequent transitions to irregularity, indicating that befallen irregularity later in Senegalese migrants' stays at destination is not related to the mode of entry. At the same time, the results from the transition model suggest that legal statuses are sticky: migrants with fully regular status were less likely to transition to irregular status than those with semi-irregular statuses, indicating that fully regular status is difficult to lose once gained. Once again, this could be interpreted as a form of capital, this time in the legal domain: Senegalese migrants are able to convert their experience in regular status into a lower probability of falling into irregularity.

Taken together, these results paint a picture of interlinked pathways of irregularity with complex relationships between different pathways. Entry with a visa, not irregular entry, is closely related to first-status irregularity in southern Europe, while it is unrelated to later transitions into irregular status. While policies focus on preventing irregular entry, these results show that this externalization of control may simply be deferring Senegalese migrants' irregularity to after arrival and creating demand for regularization mechanisms, either through formal programs or entitlement-based adjustments of status. Externalization of control, while able to curb some irregular flows, seems to do little to prevent other forms of irregularity; indeed, it creates a robust pathway into irregularity in the form of overstaying.

Forms of capital, identified in much previous research as important correlates of both migration and integration, seem to be similar to context in that they are important for access to pathways that occur early on in the migration spell, and fade in importance for subsequent transitions. Entry without a visa was less likely for those migrants who self-reported good economic status prior to the migration, indicating that those who perceive themselves as better-off have easier access to visas. Indeed, the requirements for proof of resources and the financial means or ticket for the return trip that exist in most countries' visa policies are a built-in method of selecting potential migrants on economic lines, and they must mobilize significant resources to meet these requirements (Sciortino 2004). Previous no-visa entry and belonging to the Mouride brotherhood were positively associated with the probability of no-visa entry, pointing to the importance of migration-specific and social forms of capital in this pathway. Transition to first-status irregularity was the pathway the most strongly related to forms of capital: financial (family financial help 
and self-reported economic status), social (number of contacts at destination), and migration-specific (number of previous migrations) forms of capital all reduced the probability of irregular first status. While entering with a visa is resource-intensive, gaining regular legal status once in destination is even more so.

In contrast, there was almost no relationship between these indicators of access to resources and the probability of falling into fully irregular status. Instead, this transition seems to be more related to the migrant's connection to institutions in the destination country. Having children in the destination country is associated with a reduced probability of first-status irregularity, as is having a spouse at destination. These family links thus seem to be protective against transitions into less-secure irregular statuses. While this chapter has not examined the timing of the formation of unions or the birth of children and thus cannot speak to the exact mechanism behind these associations, migrants may be accessing regular status through legal provisions for family attachment, such as family reunification or marriage to citizens.

In addition to the family, the labor market is another institution that plays a role in structuring transitions between legal statuses. Unemployment is associated with a lower probability of befallen irregularity. Thus, holding a job is not necessarily protective against befallen irregularity. While somewhat paradoxical from the point of view of the literature that argues that unemployment can lead to irregularity through the loss of a formal job contract that would allow renewal of work and residence permits, the association between employment and befallen irregularity could be an indication that Senegalese migrants who lose regular legal status are concentrated in informal labor markets. The fact that previous migration experience is also associated with befallen irregularity suggests that this form of migration-specific capital may help migrants navigate institutions such as the informal labor market (Reyneri 1998). Thus, befallen irregularity might be part of a logic of accumulation at the expense of documentation, which research suggests might be common among Senegalese migrants in Spain (van Nieuwenhuyze 2008).

\subsection{Conclusion}

Irregular migration is a controversial topic in most migrant-receiving countries around the world. Recent estimates put the undocumented population of the US at over ten million (Passel and D'Vera Cohn 2011), while Europe's irregular population is estimated to be somewhere between three and five million (Düvell 2011b). Unfortunately, understanding of this phenomenon in Europe is hampered by policy discourses and political processes that use "numbers games" (Sciortino 2004; Vollmer 2011) to placate public outcry over irregular migration by increasing border controls at the expense of the integration of migrants already in destination countries. While academic research has sought to improve methods of "counting the uncountable" to better frame policy debates, many studies have used a simplified dichotomous conceptualization of irregular status that both privileges examinations 
of only one pathway to irregularity (undocumented border crossing) and hides heterogeneity in legal statuses.

This chapter has attempted to contribute to the growing literature calling for a more complex conceptualization of irregularity by examining the pathways into a set of irregular statuses among Senegalese migrants in Europe. Context plays a strong role in shaping no-visa entry and overstay, pathways that occur early in the migration trajectory. These pathways are likely to be the most responsive to variation over time and across destination of the sociolegal parameters of legal status since most of these parameters have increasingly converged on preventing irregular entry. These early pathways of irregularity are also responsive to migrants' various forms of capital: migrants who have greater access to financial, human, and social capital are less likely to follow these paths into irregularity; migration-specific social capital in the form of prior no-visa entry facilitate current no-visa entry, but an increase in the number of previous trips protects against first-status irregularity. On average, then, access to resources gives migrants more options in terms of legal channels.

Transitions in legal status, such as overstaying and befallen irregularity, are more responsive to links to institutions in the destination country, suggesting that migrants participate actively in seeking pathways out of irregularity as part of a project of integration (van Nieuwenhuyze 2008). Employment is, somewhat paradoxically, related to increased probability of loss of regular status, which suggests that the link between labor market participation and legal status depends crucially on whether or not the migrant works in the formal sector.

In addition to findings on context and links to institutions, this study found that previous legal status was an important predictor of all of the pathways. This supports the emerging view in research on legal status that a static binary measure of legal status is not sufficient to capture the complexity of legal status categories and transitions over migrants' life courses. This study thus contributes to the call for disaggregating legal status (Donato and Armenta 2011) and examining connections between different kinds of legal status. Furthermore, these findings present an important point of articulation with research that sees legal status as an increasingly important axis of stratification (Donato and Armenta 2011; Massey 2007) and could open the door to studies that examine status mobility in the same vein as studies of traditional social mobility. Understanding the potential structuredness and pathdependency of forms of irregularity could shed new light on the impact of irregularity on migrants' life chances. 


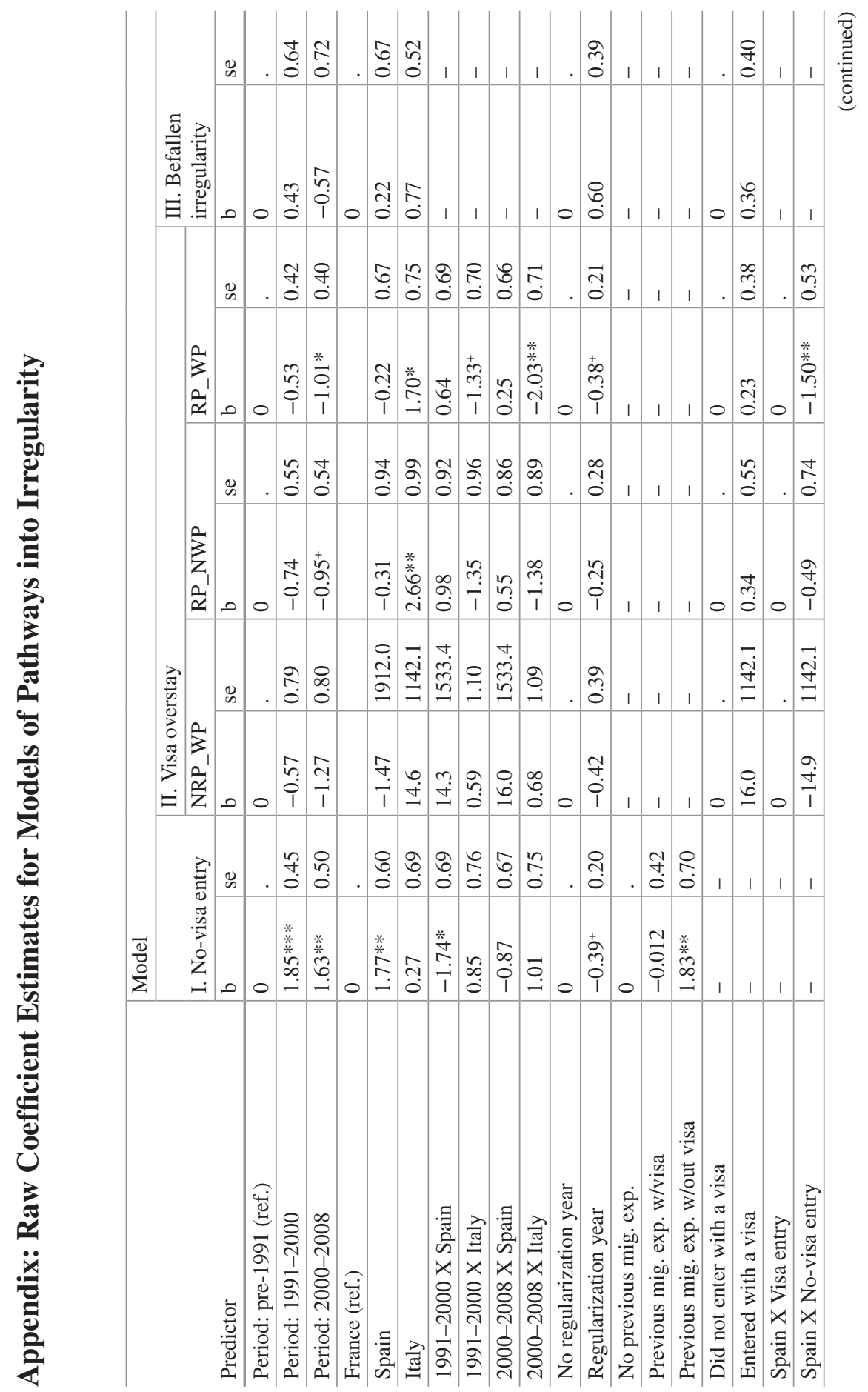




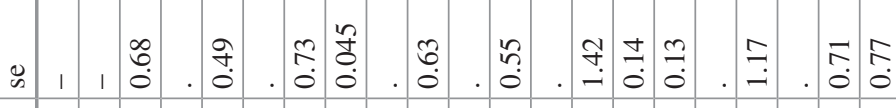

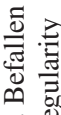
$\begin{array}{lllllllllll}2 & 1 & 1 & 0 & 0 & 0 & 0 & 0 & 0\end{array}$

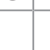

*.

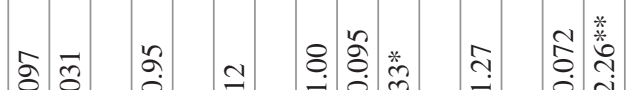

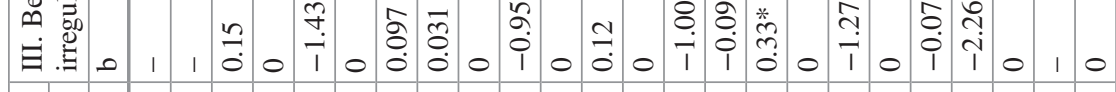
: .

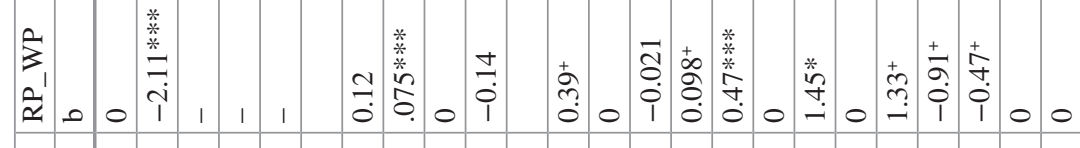

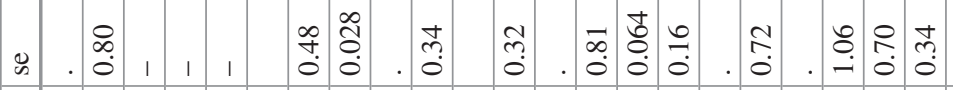

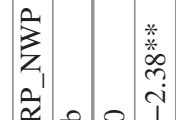
屖

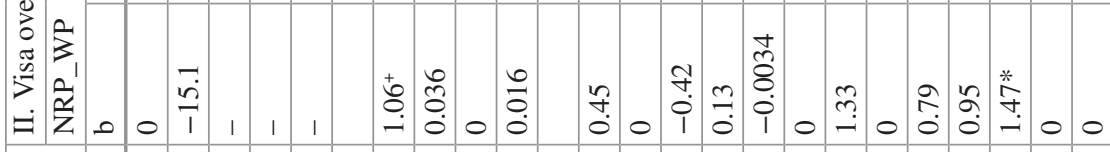

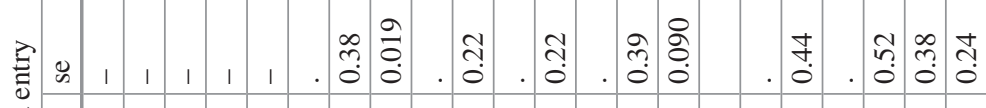

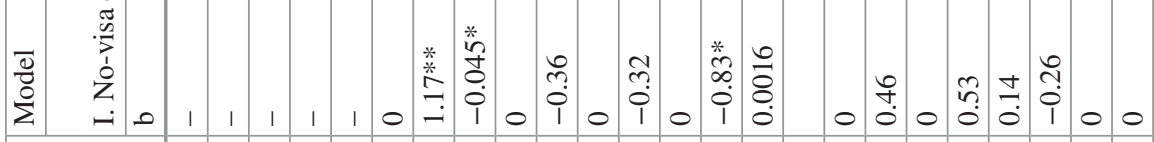

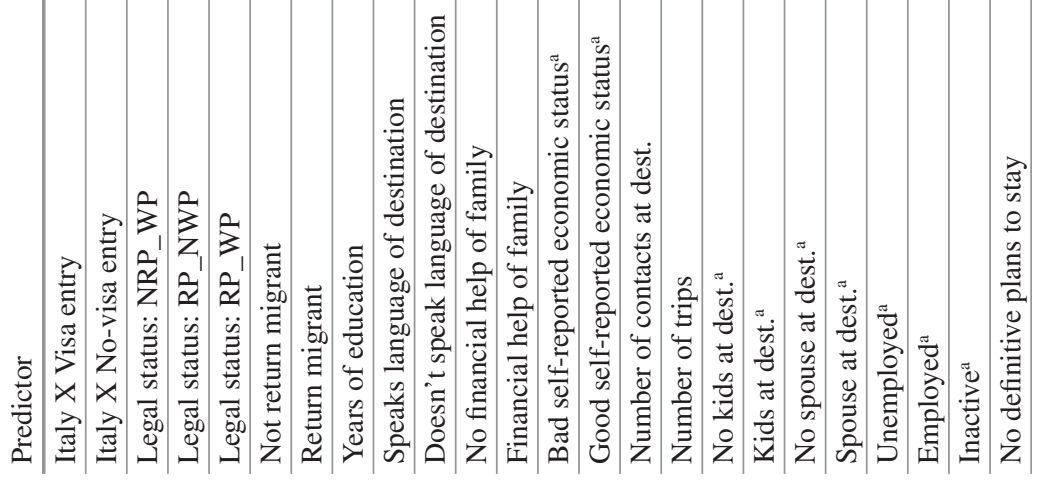




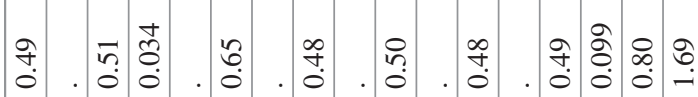

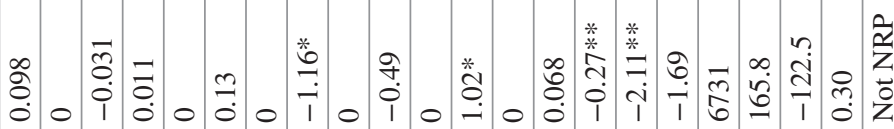

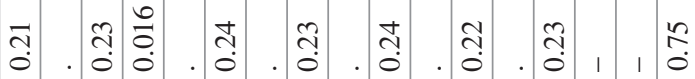

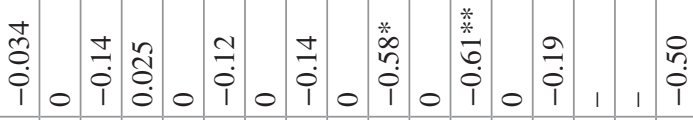

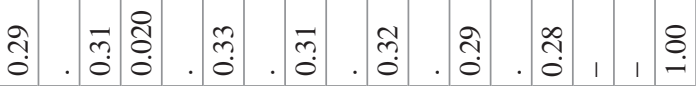

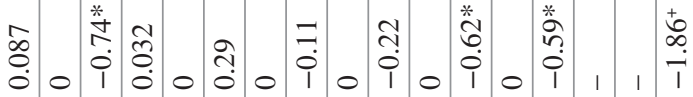

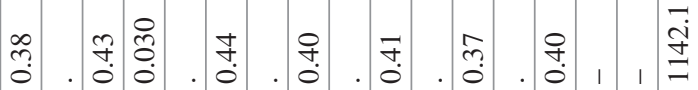

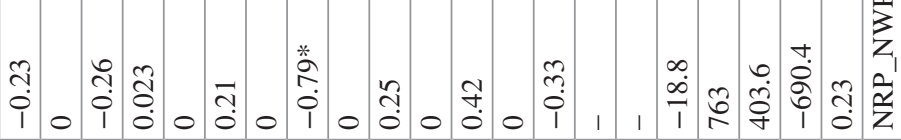

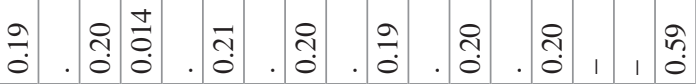

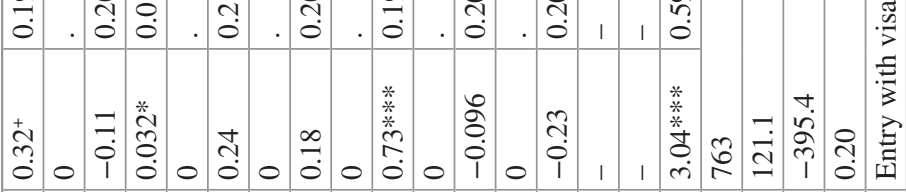

药

仓ั.

跣

胥

它

:

2.

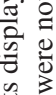

魚

응

뭉

ธี

일

․

우ㅇㅝㅛ

$\checkmark$ :

2

* 00

它总

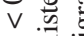

* :

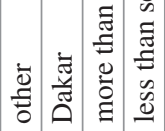

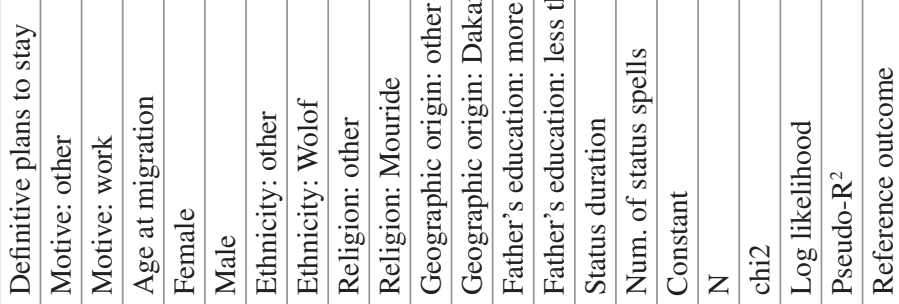

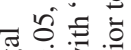

댕요

政

कै

这焉

원은

论 


\section{References}

Alba, R. D., \& Nee, V. (2003). Remaking the American mainstream: Assimilation and contemporary immigration. Cambridge, MA: Harvard University Press.

Beauchemin, C. (2012). Migrations between Africa and Europe: Rationale for a survey design. Methodological Note (Vol. 5). Paris: INED.

Beauchemin, C. (Ed.). (2018). Migration between Africa and Europe. New York: Springer Berlin Heidelberg.

Bergues, H. (1973). L'immigration Des Travailleurs Africains Noirs En France et Particulièrement Dans La Région Parisienne. Population, 28(1), 59-79.

Borjas, G. J., \& Tienda, M. (1993). The employment and wages of legalized immigrants. International Migration Review, 27(4), 712-747.

Brochmann, G. (1999). The Mechanisms of control. In G. Brochmann \& T. Hammar (Eds.), Mechanisms of immigration control: A comparative analysis of European regulation policies (pp. 1-27). Oxford: Berg.

Calavita, K. (1998). Immigration, law, and marginalization in a global economy: Notes from Spain. Law \& Society Review, 32(3), 529-566.

Cameron, A. C., \& Trivedi, P. K. (2010). Microeconometrics using stata (Revised ed.). College Station: StataCorp LP.

Courau, H. (2009). Country report France: Undocumented migration counting the uncountable. Data and trends across Europe. CLANDESTINO project.

Coutin, S. B. (1998). From refugees to immigrants: The legalization strategies of Salvadoran immigrants and activists. International Migration Review, 32(4), 901-925.

De Genova, N. (2002). Migrant 'illegality' and deportability in everyday life. Annual Review of Anthropology, 31(1), 419-447.

Donato, K. M., \& Armenta, A. (2011). What we know about unauthorized migration. Annual Review of Sociology, 37, 529-543.

Donovon, V. (1988). Réalités Françaises et Conventions Franco-Africaines de Circulation Des Personnes. Peuples Noirs Peuples Africains, 59-62, 149-164.

Düvell, F. (2008). Clandestine migration in Europe. Social Science Information, 47(4), 479-497.

Düvell, F. (2011a). Paths into irregularity: The legal and political construction of irregular migration. European Journal of Migration and Law, 13(3), 275-295.

Düvell, F. (2011b). The pathways in and out of irregular migration in the EU: A comparative analysis. European Journal of Migration and Law, 13(3), 245-250.

Fasani, F. (2010). The Quest for La Doce Vita? Undocumented Migration in Italy. In A. Triandafyllidou (Ed.), Irregular migration in Europe: Myths and realities (pp. 115-124). Surrey: Ashgate Publishing, Ltd.

Finotelli, C., \& Sciortino, G. (2009). The importance of being southern: The making of policies of immigration control in Italy. European Journal of Migration and Law, 11, 119.

Finotelli, C., \& Sciortino, G. (2013). Through the gates of the fortress: European visa policies and the limits of immigration control. Perspectives on European Politics and Society, 14(1), 80-101.

Freedman, J. (2004). Immigration and insecurity in France. Aldershot: Ashgate.

GISTI. (2011). Le guide de l'entrée et du séjour des étrangers en France. Paris: la Découverte.

Goldring, L., \& Landolt, P. (2011). Caught in the work-citizenship matrix: The lasting effects of precarious legal status on work for Toronto immigrants. Globalizations, 8, 325-341.

Goldring, L., Berinstein, C., \& Bernhard, J. K. (2009). Institutionalizing precarious migratory status in Canada. Citizenship Studies, 13(3), 239-265.

González-Enríquez, C. (2009). Spain, the cheap model: Irregularity and regularisation as immigration management policies. European Journal of Migration and Law, 11, 139.

González-Enríquez, C. (2010). Spain: Irregularity as a rule. In A. Triandafyllidou (Ed.), Irregular migration in Europe: Myths and realities (pp. 115-124). Surrey: Ashgate Publishing, Ltd. 
González-Ferrer, A. (2011a). Explaining the labour performance of immigrant women in Spain: The interplay between family, migration and legal trajectories. International Journal of Comparative Sociology, 52(1-2), 63-78.

González-Ferrer, A. (2011b). The reunification of the spouse among recent immigrants in Spain. Links with undocumented migration and the labour market. In A. Kraler, E. Kofman, M. Kohli, \& C. Schmoll (Eds.), Gender, Generations and the family in international migration (pp. $143-$ 166). Amsterdam: Amsterdam University Press.

Jandl, M. (2004). The estimation of illegal migration in Europe. Studi Emigrazione/Migration Studies, 41(153), 141-155.

Kaag, M. (2008). Mouride transnational livelihoods at the margins of a European society: The case of residence Prealpino, Brescia, Italy. Journal of Ethnic \& Migration Studies, 34(2), 271-285.

Kossoudji, S. A., \& Cobb-Clark, D. A. (2000). IRCA's impact on the occupational concentration and mobility of newly-legalized Mexican men. Journal of Population Economics, 13(1), 81-98.

Kraler, A. (2009). Regularisation: A misguided option or part and parcel of a comprehensive policy response to irregular migration? (Vol. 24). Vienna: IMPCD.

Lessault, D., \& Beauchemin, C. (2009a). Ni invasion, ni exode. Regards statistiques sur les migrations d'Afrique subsaharienne. Revue Européenne des Migrations Internationales, 25(1), 163-194.

Lochak, D. (1997). Les politiques de l'immigration au prisme de la législation sur les étrangers. In D. Fassin, A. Morice, \& C. Quiminal (Eds.), Les lois de l'inhospitabilité: les politiques de l'immigration à l'épreuve des sans-papiers, Cahiers libres (pp. 29-45). Paris: La Découverte.

Marot, N. (1995). L'évolution des accords franco-africains. Plein droit, 29-30, 96-99.

Massey, D. S. (2007). Categorically unequal: The American stratification system. New York: Russell Sage Foundation.

Massey, D. S., \& Capoferro, C. (2004). Measuring undocumented migration. International Migration Review, 38(3), 1075-1102.

Massey, D. S., \& Espinosa, K. E. (1997). What's driving Mexico-U.S. migration? A theoretical, empirical, and policy analysis. The American Journal of Sociology, 102(4), 939-999.

Massey, D. S., Arango, J., Hugo, G., Kouaouci, A., Pellegrino, A., \& Edward Taylor, J. (1998). Worlds in motion: Understanding international migration at the end of the millennium. Oxford: Clarendon Press.

Massey, D. S., Durand, J., \& Malone, N. J. (2002). Beyond smoke and mirrors: Mexican immigration in an era of economic integration. New York: Russell Sage Foundation.

Massey, D. S., Durand, J., \& Pren, K. A. (2016). Why border enforcement backfired. American Journal of Sociology, 121(5), 1557-1600.

Menjívar, C. (2006). Liminal legality: Salvadoran and guatemalan immigrants' lives in the United States. American Journal of Sociology, 111(4), 999-1037.

Mezger, C., \& González-Ferrer, A. (2013). The impol database: A new tool to measure immigration policies in France, Italy and Spain since the 1960s (Vol. 34). Paris: INED.

Passel, J. S., \& D'Vera Cohn, S. W. (2011). Unauthorized immigrant population: National and state trends, 2010. Washington, D.C: Pew Hispanic Center.

Pastore, F., Monzini, P., \& Sciortino, G. (2006). Schengen's soft underbelly? Irregular migration and human smuggling across land and sea borders to Italy. International Migration, 44(4), 95-119.

Phillips, J. A., \& Massey, D. S. (1999). The new labor market: Immigrants and wages after IRCA. Demography, 36(2), 233-246.

Portes, A. (2010b). Migration and social change: Some conceptual reflections. Journal of Ethnic and Migration Studies, 36(10), 1537.

Portes, A., \& Rumbaut, R. (2001). Legacies: The story of the immigrant second generation. Berkeley: University of California Press.

Portes, A., \& Rumbaut, R. (2006). Immigrant America: A portrait (3rd ed., rev.expanded, and update). Berkeley: University of California Press. 
Reyneri, E. (1998). The role of the underground economy in irregular migration to Italy: Cause or effect? Journal of Ethnic and Migration Studies, 24(2), 313.

Riccio, B. (2008). West African transnationalisms compared: Ghanaians and Senegalese in Italy. Journal of Ethnic \& Migration Studies, 34(2), 217-234.

Ruhs, M., \& Anderson, B. (2010). Semi-compliance and illegality in migrant labour markets: An analysis of migrants, employers and the state in the UK. Population, Space and Place, 16(3), 195-211.

Schuster, L. (2005). The continuing mobility of migrants in Italy: Shifting between places and statuses. Journal of Ethnic and Migration Studies, 31(4), 757-774.

Sciortino, G. (1999). Planning in the dark: The evolution of Italian immigration control. In G. Brochmann \& T. Hammar (Eds.), Mechanisms of immigration control: A comparative analysis of European regulation policies (pp. 233-260). Oxford: Berg.

Sciortino, G. (2004). Between phantoms and necessary evils. Some critical points in the study of irregular migrations to Western Europe. In A. Böcker, B. de Hart, \& I. Michalowski (Eds.), IMIS-beiträge: Migration and the regulation of social integration. Osnabrück: Institut für Migrationsforschung und Interkulturelle Studien (IMIS).

Singer, A., \& Massey, D. S. (1998). The social process of undocumented border crossing among Mexican migrants. International Migration Review, 32(3), 561-592.

Spire, A. (2005). Etrangers à la carte: L'administration de l'immigration en France (1945-1975). Paris: Grasset.

Timera, M., \& Garnier, J. (2010). Les Africains En France: Vieillissement et Transformation d'une Migration. Hommes \& Migrations, 1286-1287, 24-35.

Triandafyllidou, A. (2010a). Irregular migration in Europe in the 21st Century. In A. Triandafyllidou (Ed.), Irregular Migration in Europe: Myths and Realities (pp. 1-21). Surrey: Ashgate Publishing, Ltd.

Triandafyllidou, A. (Ed.). (2010b). Irregular migration in Europe: Myths and realities. Surrey: Ashgate Publishing, Ltd.

van Nieuwenhuyze, I. (2008). Getting by in Europe's urban labour markets: Senegambian migrants' strategies for survival, Documentation and Mobility. Amsterdam: Amsterdam University Press.

Vollmer, B. A. (2011). Policy discourses on irregular migration in the EU - Number games and political games. European Journal of Migration and Law, 13(3), 317-339.

Wihtol de Wenden, C. (2010). Irregular migration in France. In A. Triandafyllidou (Ed.), Irregular migration in Europe: Myths and realities (pp. 115-124). Surrey: Ashgate Publishing, Ltd.

Open Access This chapter is licensed under the terms of the Creative Commons Attribution 4.0 International License (http://creativecommons.org/licenses/by/4.0/), which permits use, sharing, adaptation, distribution and reproduction in any medium or format, as long as you give appropriate credit to the original author(s) and the source, provide a link to the Creative Commons licence and indicate if changes were made.

The images or other third party material in this chapter are included in the chapter's Creative Commons licence, unless indicated otherwise in a credit line to the material. If material is not included in the chapter's Creative Commons licence and your intended use is not permitted by statutory regulation or exceeds the permitted use, you will need to obtain permission directly from the copyright holder.

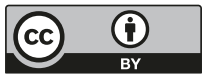




\section{Chapter 4 \\ Legal Status, Gender, and Economic Incorporation of Senegalese Migrants in France, Italy, and Spain}

The economic integration of migrants is a major concern for policy makers, as is the legal status of immigrants in the labor market. While immigration-control legislation that confers residence and work authorization should theoretically mediate migrants' access to the labor force, the presence and economic activity of millions of undocumented migrants in different receiving countries indicates that irregular legal status is often not a barrier to work. Indeed, some research suggests that immigrants are able to find work precisely because of their irregular status, which removes most legal recourse against exploitation by unscrupulous employers (Portes 1978). Migrants are thus assumed to have economic motivations for their migration and to work in the destination economy regardless of their legal status.

This common perception of the link_-or lack thereof-between migrants' legal status and their economic incorporation fails to consider the role of gender. While post-war labor migration, both regular and irregular, to the U.S. and Western Europe was mostly male, flows of immigrants since the 1970s have seen an increasing share of women, many of whom entered through legal channels of family reunification (Kofman 1999). Although research has underlined the heterogeneity of these migrant women's legal and economic situations, family-reunification policies have been highly gendered and have largely consigned women to economic and administrative dependency on their male sponsors. In addition, countries award different configurations of authorizations to reunified family members, thus creating a variety of forms of dependency (González-Ferrer 2011b).

Despite possessing a form of regular legal status, then, migrant women may initially be less likely to work than their male counterparts. While this has provoked

\footnotetext{
The original version of this chapter was revised: Footnote was inserted in the chapter opening page. The correction to this chapter is available at https://doi.org/10.1007/978-3-030-12088-7_7

Portions of Chapter 4 were previously published as: Vickstrom, E. R., \& González-Ferrer, A. (2016). Legal status, gender, and labor market participation of Senegalese migrants in France, Italy, and Spain. The Annals of the American Academy of Political and Social Science, 666(1), 164-202. https://doi.org/10.1177/0002716216643555.
} 
concerns about the growing numbers of inactive and "unproductive" migrants in some countries (Constant and Zimmermann 2005), the initial gendered asymmetry of economic integration may obscure subsequent mobility among women into the labor market. The impact of legal status on migrants' economic integration thus seems to depend crucially on gendered channels created by immigration policies.

This chapter will draw on the literature on the gendering of immigration policies to examine the link between legal status and economic incorporation of Senegalese migrants in France, Italy, and Spain. It argues that the effect of legal status on Senegalese migrant's labor-market participation will vary differ for men and women because of gendered immigration policies. The chapter is organized as follows. The next section reviews the literature on gendered immigration policies and the creation of migrant women's economic and administrative dependency. The third section lays out the chapter's hypotheses. The fourth section reviews the data and presents the methods. The fifth section presents the results, and the sixth section discusses the findings and concludes.

\subsection{Gendered Channels of Migration: Family Reunification, Legal Status, and Dependency}

Research since the 1980s has increasingly focused on the exclusion of women from studies of the economic incorporation of migrants (Kofman 1999, 2004a). One of the main insights of this body of research is that immigration policies, while officially gender-neutral, have differential impacts on the mobility and subsequent economic integration of male and female migrants (Lesselier 2008). Men were the primary beneficiaries of labor-recruitment policies in both the US and Western Europe up through the 1960s and 1970s (Lesselier 2008; Mahler and Pessar 2006). Governments, especially those in Western Europe, severely restricted these legal channels of labor immigration after the mid-1970s but continued to allow migrants legally residing in destination countries to bring close family members under family reunification schemes.

Indeed, family reunification has become the main channel of legal entry to most Western European countries (Kofman 1999). In France, for example, $70 \%$ of entries in 2008 were for family reasons, and family reunification with long-term foreign residents make up between 90,000 and 150,000 entries per year since 2000 (Lesselier 2008). Research has shown, though, that family reunification is highly gendered: women, mostly spouses, make up the majority of reunified family members (Kofman 1999). Fully $80 \%$ of the aforementioned annual entries for family reunification in France were women (Lesselier 2008). While not all women are reunified spousesresearch has increasingly pointed to a growing "feminization" of autonomous migration (Kofman 2004b) - family reunification remains the dominant channel of entry for women into most destinations and structures their legal and economic incorporation. 


\subsubsection{Reunification and Gendered Economic and Administrative Dependency}

Research has shown that family reunification policies create economic and administrative dependency for women, and that these forms of dependency have implications for women's economic participation in destination-country labor markets (Boyd 1997; Lesselier 2008). Economic dependency among reunified spouses may arise from the legal requirements of demonstration of means of support by the sponsor. Family reunification policies often define male migrants as the primary breadwinners through the economic conditions imposed for reunification (Kofman 2004a; Mahler and Pessar 2006), creating economic dependency of women on their husband's income (Lesselier 2008). Reunified spouses may thus be less likely to work because of their sponsors' relatively high socioeconomic status (Toma 2012).

Economic dependency of reunified spouses may also arise because of legal barriers to their labor-market participation. Legislation may formally prevent women from accessing the labor market by imposing waiting periods on the ability of reunified spouses to apply for and receive work permits, as is the case in Italy and Spain (Kofman 1999). The separation of residence and work permits that is common in Europe thus means that the legal right to reunify is not always synonymous with the legal right of reunified spouses to enter the labor force (Boyd 1989). Indeed, research on the "admission category" of migrants has generally found that refugees and reunified family members have worse labor-market outcomes than those of economic migrants (Constant and Zimmermann 2005); these findings demonstrate the barriers that admissions policies impose rather than the motivations or unobserved characteristics of the admitted migrants (González-Ferrer 2011a). Reunified women who are excluded from the labor force as a result of legal waiting periods are thus dependent on their spouses for economic support, or they are forced to work illegally. Indeed, reunified women who have economic in addition to family motivations for migration may bypass the legal reunification channel because it is, in effect, no different from irregular channels of reunification in terms of accessing the labor market (González-Ferrer 2011a).

In addition to economic dependency as a result of family reunification, women are often subject to administrative dependency. Immigration legislation makes the possibility of reunification conditional on the sponsor's regular legal status (Lesselier 2008). Women wishing to rejoin their husbands legally are therefore dependent on his acquisition of regular legal status. In addition, the legal status of reunified spouses after arrival is dependent on the primary migrant's continued possession of regular legal status and the continuation of the marriage (Lesselier 2008). Women's geographic mobility is thus subject to dependency both in relation to the state and within the household (Kofman 2004b). These asymmetric power relations may reduce women's autonomy in making decisions about labor-market participation by tying them administratively to a husband's legal situation. This dependency can decrease women's bargaining power within the household, giving them less voice in their husbands' decisions in the allocation of their labor to either productive or reproductive efforts (Kofman 1999). In countries such as France where there is no 
waiting period for applying for a work permit, administrative dependency can still hamper reunified wives' labor participation by tying women's legal right to work to men's regular status (Lesselier 2008).

The administrative dependency fostered by family reunification also creates a gendered pathway into irregular status. Family reunification is not an automatic right conferred on migrants; on the contrary, states have imposed increasingly restrictive conditions that primary migrants have to meet before being allowed to bring family members to the destination country (Kofman 2004a). These conditions often require the sponsor to have a minimum period of prior residence, a stable income, and adequate housing in addition to regular legal status. The reunification of women whose husbands lack regular status or any of the other legal conditions must take place outside of the formal legal channel of reunification-for example, by overstaying an entry for tourism or other purposes (Lesselier 2008). Empirical research has shown that restrictive conditions do indeed lead to the incentivization of reunification outside or on the fringes of the legal system, especially among reunified wives who work upon arrival (González-Ferrer 2011b).

\subsubsection{Family Reunification Regimes and Configurations of Legal Status}

The specific legal rights granted to reunified migrants varies across destinations, giving rise to different configurations of legal status corresponding to different types of migrants in different countries. For the purposes of this chapter, it is useful to examine the configurations of legal status granted to reunified spouses in France, Italy, and Spain. In France, the legal reunification channel has consistently conferred the legal right to reside and work to reunified spouses (Lesselier 2008). Thus, women who follow the legal channel in France have legal authorization to work upon arrival. In Italy and Spain, however, immigration legislation has imposed a waiting period on reunified spouses' access to the labor markets; reunified spouses are thus likely to possess a residence permit but lack a work permit (GonzálezFerrer 2011b; Kofman 1999). The legal status granted to migrants in the category of "reunified spouses" and the concomitant legal access to the labor market thus varies across destinations. This variation is captured in the typology presented in Table 4.1.

Identical configurations of legal status can signal different types of migrants under different legal regimes, as is evident in Table 4.1. For example, migrants in France who lack a work permit - the legal status afforded to reunified spouses in

Table 4.1 Typology of female migrant types by legal status and country

\begin{tabular}{l|l|l|l}
\hline \multirow{2}{*}{ Country } & Legal status & Irregular \\
\cline { 2 - 4 } & Regular & Mixed & Multiple \\
\hline France & Reunified spouse & Student & Multiple \\
\hline Spain & Worker & Reunified spouse & Multiple \\
\hline
\end{tabular}


Italy and Spain — are likely to be students. In contrast, migrants in Spain and Italy with both a residence permit and a work permit - the legal status afforded to reunified spouses in France-are most likely labor migrants. There is thus substantial heterogeneity in the formal rights accorded to different admissions categories, making it imperative to examine both family context and legal status when considering the effect of family reunification on women's economic integration.

\subsection{Reunified Women and the Labor Market}

The economic and administrative dependency created by legal channels of family reunification may thus constrain women's legal participation in the labor force. Women have been marginalized in labor migration in part because many immigration policies implicitly assume that women are passive followers who do not seek employment (Kofman 2004a). Early research on the link between family ties and women migrants' economic participation tended to confirm this image. The "family migration model" (Sandell 1977) has traditionally seen migration as a disruptive event in women's work lives: women are assumed to move as part of a family migration unit, and thus will still migrate even if they are expected to have lower participation rates after arrival because the net benefit of a move for the family unit as a whole is positive (Mincer 1978; Sandell 1977).

Nonetheless, while the predominance of the family reunification channel for women has limited their ability to migrate and work independently, reunification does not necessarily preclude participation in the labor force. Research has shown that family migration, far from hampering a tied mover's economic participation, can often lead to women's employment: the "family investment model" contends that women whose spouses have the highest expected earnings in a destination may actually be more likely to participate in the labor force and to be employed as a way of supporting their husbands' investments in destination-specific human capital (Duleep and Sanders 1993). Women's family context and the potential labor-market success of a spouse thus emerge as important determinants of their labor-market performance.

Given that admission category/type of migration is not necessarily synonymous with the often-multifaceted motivations for migration, it is also important to be attentive to transitions over time in both legal status and labor-force participation after the year of arrival. Immigration policies with waiting periods build into their reunification regimes eventual transitions from the initial status defined by this entry category: reunified spouses can eventually apply for formal permission to enter the labor force. Women's and households' preferences about the allocation of female labor may also shift over time, meaning that even reunified spouses who do not initially work despite a legal authorization to do so may eventually end up in the labor force. Transitions into the labor market have been observed among reunified spouses, leading to the observation that family migration does not mean the end of labor migration, only its transformation because many family migrants eventually end up as de facto labor migrants (Kofman 1999). Indeed, women may have economic motivations for "associational" moves, and may use family reunification 
strategically to enter labor markets while at the same time following socially sanctioned channels of mobility (Kanaiaupuni 2000).

When women do work, a gendered labor market funnels women into specific jobs, mostly in the informal sector (Kofman 1999; Lesselier 2008). An example is the increasing demand for domestic workers, especially in Southern Europe, which draws women into low-skill, low-wage work (Kofman 1999, 2004b). Some countries, such as Italy and Spain, actively recruit female workers via employment quotas for low-skill domestic work (Kofman 2004b), while immigration legislation has also pursued high-skill migrants who tend to be male (Lesselier 2008; Raghuram 2004). Thus, when immigration policies allow female migrant labor, they actively channel women into specific low-wage sectors of the economy (with the exception of some female high-skill healthcare professionals, see Raghuram 2004). In countries such as France where legal channels of labor immigration do not include such gendered occupations, women migrating autonomously for work are especially likely to do so irregularly (Lesselier 2008). Immigration policies thus conspire with gendered labor demand to create differential legal immigration channels and pathways of irregularity for men and women.

\subsection{Limitations of Existing Research}

It is thus clear that the labor-market participation of female migrants is heterogeneous and is linked to their family context and the legal opportunities afforded by family-reunification policies, but much existing research on the legal status and immigrant economic incorporation has been blind to the gendered nature of immigration policies and the legal statuses they create. Most studies in the US context do not examine the possibility that the effect of different legal statuses might differ for men or women, nor do they consider alternative measures of economic incorporation such as labor-market participation or employment. Research in Europe has considered employment as an outcome in a context with institutional variation in labor markets across multiple contexts of reception but has not been able to measure legal status or its differential effects for men and women.

\subsubsection{Assuming Participation: Undocumented Status and Wages in the US}

Most studies of the link between legal status and migrant economic incorporation in the US find that undocumented status is associated with lower wages. Much of this research has used data from the Legalized Population Survey (LPS), conducted with a sample of undocumented migrants who were legalized by the 1986 Immigration Reform and Control Act (IRCA), to show that legalization was associated with an improvement in the economic opportunities among migrants whose status was adjusted (Kossoudji and Cobb-Clark 2000, 2002; Rivera-Batiz 1999); gaining regular legal status thus contributed positively to economic outcomes for migrants. 
At the same time, research has found that undocumented migrants faced additional deterioration in their earnings as a result of the stiffer penalties of this legislation, with employers passing on to them the costs and risks of unauthorized hiring (Donato and Massey 1993; Phillips and Massey 1999). Recent research, using recent longitudinal data with a larger comparison group and growth-curve modeling techniques, has continued to uncover disparities in earnings between documented and undocumented migrants (Hall et al. 2010).

The assertion of a negative effect of undocumented status must be re-examined in light of the gendering of both migration policies and labor-market participation. Unfortunately, the studies cited above focus only on the United States and almost exclusively on Mexican men. While undoubtedly an important case to study given high share of all immigrants in the US that this group makes up, it is also a case with a distinct history and social and economic infrastructure (Massey et al. 2002) that, in some ways, might limit its generalizability. In looking almost exclusively at wages, these studies implicitly select only migrants who are both active in the labor market and employed. While some studies do attempt to model the effect of selection into the migrant labor force on wages (Donato and Massey 1993; Massey 1987), the issue of differential migrant participation in the labor market is not addressed as a main topic of concern.

The assumption of both activity and employment might have held for earlier migration flows that were dominated by single, male workers (Piore's (1979) "birds of passage"), but most migration streams, even among Mexicans to the US, have diversified in recent years. Women have made up larger shares of both documented and undocumented Mexican migrants since 1986, and accounted for $45 \%$ of all Mexican migrants in the US in 2004 (Donato et al. 2008). Research has shown, though, that Mexican men and women in the US have different motivations for migration: men tend to be motivated by employment and often move alone, while women almost always follow another family member and thus tend to have family motivations for their migration (Cerrutti and Massey 2001). The gendered nature of work means that these female migrants have different labor profiles than their male compatriots (Donato et al. 2008). Cultural understandings of women's role in the family have limited Mexican migrant women's ability to work: only $47 \%$ of Mexican-born adult women in the US were in the labor force in 2006, compared to $88 \%$ of Mexican-born adult men (Donato et al. 2008). Motivations and value systems thus combine with reunification policies to limit women's participation in the labor market. Migrant women's economic integration in destination countries thus differs from that of men, and a focus on wages as the principal indicator of integration as in the US case excludes many women from the analyses.

\subsubsection{Ethnic Penalties on Employment in Europe, but Limited Measures of Legal Status}

The European research on immigrant economic incorporation helps to fill some of the blind spots in the American literature. Unlike in the US, studies of immigrant labor-market incorporation in Europe, where unemployment has historically been 
higher among both native-born and foreign workers, take the explanation of the likelihood of employment as a point of departure. This research has found, in general, that immigrants can often face an "ethnic penalty" (Heath and Ridge 1983) that translates into lower rates of employment compared to similar native-born workers (see Reyneri and Fullin 2011 for a review).

This general finding is tempered, however, by an insistence on cross-national variations in both the composition of migrant flows and institutional factors in the destination countries such as immigration policies, labor-market structures, and welfare regimes. Kogan (2006) finds that male migrants from sub-Saharan Africa in fourteen European countries are substantially disadvantaged in their probability of employment compared to native workers even after adjusting for human-capital endowments, while migrants from Asia and Latin America have lower rates of unemployment than natives. This study also finds significant institutional variation across countries in the employment penalty: migrants face a lower penalty in countries with high demand for low-skilled labor, in countries with more flexible labor markets, and in countries with "liberal" welfare regimes, such as the UK and Ireland, that emphasize mobility and flexibility (Kogan 2006).

These cross-national institutional differences make a strong case for the importance of studying employment as an indicator of the labor-market incorporation of migrants (González Ferrer 2006). Earnings assimilation is a good measure of adaptation in countries with a flexible labor market and a low minimum wage, where immigrants can compensate for initial lower host-country human capital by accepting lower pay (González Ferrer 2006); time spent in destination can help immigrants build human capital and "catch up" to natives in earnings, as has been found in the US (Borjas 1985, 1995; Chiswick 1978). Institutional features such as labormarket flexibility, however, vary cross-nationally, and in countries with less-flexible labor markets there has been little evidence of earnings assimilation. These are the labor markets identified by the cross-national research as subjecting immigrants to an employment penalty, and additional years in the destination might reduce earnings because of lack of initial attachment to the labor market (González Ferrer 2006). Assimilation in the probability of employment is thus the process of primary concern in understanding the labor-market performance of immigrants in highly regulated countries (González Ferrer 2006).

Unfortunately, the European cross-national research is hampered by a number of issues that limit its applicability to the study of the impact of legal status on immigrant economic incorporation. The biggest limitation is the inability of many studies to include direct measures of migrants' legal statuses. While comprehensive measures of legal status are increasingly available in a variety of surveys such as the Immigrant Citizen Survey (Huddleston et al. 2012), many studies simply compare legal immigrants to natives because more detailed data on legal status are not available. Study designs either precluded sampling irregular migrants (Kogan 2006) or did not include questions on legal status (Bernardi et al. 2011). Even though studying the impact of legal status might not be the principle aim of these studies, they either acknowledge that the absence of unauthorized migrants in the sample may bias results (Kogan 2006) or point to the presence of unauthorized migrants as 
potential explanations for their findings (Bernardi et al. 2011). It is thus implicitly assumed that the legal limitations faced by migrants who lack regular status relegate them to temporary, low-skilled jobs in the informal sector that offer little opportunity for mobility, and that this unobserved heterogeneity contributes to the poor outcomes observed for all migrants (Bernardi et al. 2011).

The lack of direct measures of legal status also hamper European studies' ability to examine the interaction between gendered family reunification policies, the legal statuses they create, and the differential economic outcomes of men and women. Those studies that do include measures of legal status often do not consider the gendered family and legal context of women's work. Studies in Spain using the Encuesta Nacional de Inmigración (ENI) show that lack of regular status constitutes both a barrier to employment and a brake on earnings for immigrants in Spain (Amuedo-Dorantes et al. 2013; Bradatan and Sandu 2012), but do not consider how the effect of legal status might vary for men and women nor do they differentiate between different types of migrants based on family context.

The literature reviewed above demonstrates that gender is a crucial factor to take into account when studying migration. While men certainly display a wide variety of motivations for migration, women's migration is extremely heterogeneous. Women are overrepresented in legal family-reunification flows, indicating that they face legal and social constraints on their mobility arising from the gendering of migration policies. At the same time, women also migrate outside of legal reunification channels, either as informal reunifiers or as autonomous migrants and with a wide variety of legal statuses. This diversity in types of female migration creates a variety of labor-market trajectories. The existing literature on migrant economic incorporation is largely unable to deal with this diversity as it does not account for either differential labor-force participation or the interaction between legal status and gender. This chapter will adopt an approach that is sensitive to the diversity of female migration types while also comparing women to men.

\subsection{Gender Norms, Family Reunification, and Work Among Senegalese Migrants}

Senegalese society is strongly stratified along gender lines, and this stratification has implications for Senegalese women's geographical mobility and economic integration. Toma (2012) reviews the literature on gender norms in Senegal and argues that gender strongly determines life prospects there. The "traditional conjugal contract" subordinates women to the authority of a breadwinner husband within the household and, by assigning women to household tasks, places them outside of public life (Toma 2012). The Senegalese nuptial system is patrilocal, with women residing with her husband's parents after marriage and providing labor to that household. Polygamy is also widespread in Senegal, and women must often inhabit the same household as their co-wives (Toma 2012). As a result of these gender 
norms, women's work outside the home is stigmatized. In addition, women tend to be less educated than men and thus less likely to participate in the labor force: according to Demographic and Health Survey (DHS) data, only 38\% of Senegalese women were working in 2006, compared to $66 \%$ of men (Toma 2012).

Research on family reunification among Senegalese migrants in Europe has found that Senegalese are reluctant to reunify wives of male migrants and has linked relatively low levels of reunification to traditional gender norms. Multi-sited families and conjugal distance are common in Senegalese society, meaning that spouses are used to physical separation (Beauchemin et al. 2013). While early Senegalese migration to France was based on a model of circular mobility wherein male migrants could regularly travel home to visit family and wives, increased state regulation and economic crisis in the mid-1970s (see Chap. 2) made this mobility more complicated. Some Senegalese migrants responded by reunifying their wives in France, but reunification was never a universal objective of Senegalese migrants partly because of the difficulty of reunifying polygamous households (Beauchemin et al. 2013). In the new destinations of Italy and Spain, different social origins meant that Senegalese migrants were not subject to the same traditional authority as Senegalese migrants in France, but Senegalese in new destinations also tended to be members of the Mouride Islamic brotherhood; combined with economic consideration, this religious adherence has made Senegalese migrants in new destinations also reluctant to bring their spouses from Senegal (Beauchemin et al. 2013). Evidence from the MAFE project indicates that only $13 \%$ of Senegalese migrants in Europe are a part of totally reunified families, while almost half live in a different country from their spouse(s) and child(ren) (Beauchemin et al. 2013).

Despite the reluctance of Senegalese migrants in Europe to reunify, research has also shown that family reunification remains an important channel for the migration of Senegalese women to Europe. Approximately $40 \%$ of women in the MAFE sample reunite with a partner at destination, and having a partner abroad is associated with substantially increased odds of migration among Senegalese women (Toma 2012). While female autonomy is low in Senegal and independent migration of Senegalese women is socially discouraged, there is some evidence of increasing migration of single women from Senegal (Beauchemin et al. 2013). Nonetheless, even single Senegalese women are unlikely to migrate without having ties to close family members at destination, indicating that even they face a degree of social control (Toma 2012).

The occupational profile of Senegalese migrants has varied over time and destinations. Senegalese men were commonly employed in low-skilled manual jobs in France, especially as garbage collectors in Paris (Barou 1993). Senegalese women started migrating to France in the 1970s under the auspices of family reunification as Senegalese men responded to the imposition of the requirements of residence permits in 1974 (see Chap. 2). (Timera 1997). The Senegalese women who came to France as reunified spouses eventually found work in unskilled service jobs (Barou 1993). In addition, high-skilled migrants and students from Senegal increasingly 
chose to go to France because of language ties and the similarities in the educational systems of the two countries (Toma 2012). These migrants often occupy whitecollar jobs in the public administration.

Senegalese migrants first started settling in Italy in the late 1980s and worked as informal street peddlers in Rome and on the beaches of Italy's tourist areas (Schmidt di Friedberg 1993). While this occupation is associated with irregular legal status and inability to find a better job in the Italian labor market (Riccio 2001; Schmidt di Friedberg 1993), other Senegalese migrants may embrace this occupation as a part of a "transnational livelihood" (Kaag 2008). After Italian regularization campaigns in the late 1980s and early 1990s, Senegalese also moved to the north of Italy to work for wages in manual jobs in small industry, construction, and food processing (Riccio 2008; Tall 2008), while many others remain traders.

In Spain, Senegalese, like other African migrants, are concentrated in unskilled jobs in agriculture, construction, and services (Pascual de Sans et al. 2000). Jobs in Spanish agriculture tend to be seasonal and pay low wages; construction work tends to pay better but it also temporary (Toma 2012). In addition to these manual jobs, Senegalese also work in street peddling in Spain (Toma 2012). Quantitative research on Senegalese occupational trajectories has confirmed that Senegalese migrants experience a drop in occupational status after arrival in Europe (Obucina 2013).

These descriptions indicate diversity in the contexts of reception, legal statuses, and socio-demographic characteristics among Senegalese migrants in Europe. While some research has suggested that sub-Saharan Africans living in Europe face difficulties in finding a job because of their low levels of qualifications (GonzálezEnríquez 2009), other studies have found that work is relatively easy to come by, partly as a result of the rejection of manual labor among native-born workers, but that the wages are low and the working conditions poor (Pascual de Sans et al. 2000). This inconsistency, while undoubtedly related to differences in timing of the studies, likely reflects a difference in labor-market regulations and the extent of informal economies, as Senegalese migrants tend to face higher unemployment in France (Tall 2008), but tend to have worse jobs when employed in southern Europe.

These variations are also related to legal statuses: Senegalese migrants have benefitted from multiple amnesty programs in southern Europe that have allowed transitions between formal and informal work, while they have been increasingly subject to restrictive immigration-control policies in France, which has likely made such mobility difficult. Finally, the characteristics of Senegalese migrants differ across these countries: Senegalese migrants in France tend to be more educated than those in Italy and Spain, where they may have the greatest ability to convert their human capital into employment (Castagnone et al. 2013). There is also an extreme gender imbalance across these countries: $45 \%$ of Senegalese migrants in France are women, compared to only $23 \%$ in Spain and 15\% in Italy (Toma 2012). This imbalance partly reflects differential preferences for family reunification across countries (Baizan et al. 2011; Kaag 2008) and thus has implications for both the legal statuses and the economic incorporation of Senegalese migrants. 


\subsection{Hypotheses}

The legal parameters governing family reunification and social parameters of the family context of individuals' migration are thus important determinants of both legal status of reunified spouses and their economic integration at destination. Given the gendered nature of family-reunification flows, these legal and social parameters are likely to be more important for women than for men. The economic and administrative dependency associated with family-reunification policies suggest that Senegalese women migrating for family reasons in the context of legal family reunification will be less likely to work upon arrival than either women migrating autonomously or men.

Cross-national variation in the rights accorded to reunified migrants suggests that different configurations of legal status in different countries will be related to both family reunification and economic integration (see Table 4.1). Regular status (having both a residence permit and a work permit) among Senegalese women in France is likely to indicate family reunification and thus be associated with lack of labor-market participation upon arrival. In contrast, mixed status (possessing a residence permit but lacking a work permit) among Senegalese women in Italy and Spain is likely to indicate family reunification and thus be associated with lack of labor-market participation upon arrival.

In contrast to Senegalese women who migrate for family reunification, Senegalese women who migrate autonomously will be more likely to be employed upon arrival. This category includes women with fully regular status in Italy and Spain. While women with mixed status in France are likely to be students, their relative autonomy may also make them more likely to seek to enter the labor market. Women with irregular status in all three countries may also seek to participate in the labor market; women with irregular status may be autonomous or non-formal family reunifiers, either of which could be consistent with economic motivations for migration.

Senegalese men's economic integration at destination, in contrast to that of Senegalese women, will not be as closely linked to channels of family reunification. Men's employment upon arrival will be more closely associated with cross-national variation in labor-market segmentation and demand for low-skilled labor as research has found that immigrants, even the undocumented, do not necessarily face an employment penalty in such economies; thus Senegalese men in Italy and Spain will be more likely to work than Senegalese men in France. Given the size of the informal economy in southern Europe, irregular status may also be associated with increased employment among men.

The empirical analysis will also focus on employment dynamics for both women and men. While family reunification may be related to inactivity among women during the year of arrival, it does not necessarily preclude eventual labor-market participation. Women who lack the legal authorization to work upon arrival can eventually apply for it, and those who possess work authorization from the beginning of their stay may also eventually work. Thus, Senegalese women who possess 
both a residence and work permit after the year of arrival are likely to make a transition into employment.

As Senegalese men are likely to be in the labor force from the beginning of their stay at a destination, the dynamic analysis will focus on transitions out of employment (or, equivalently, into unemployment). Senegalese men with regular status are likely to be the least likely to transition into unemployment because of provisions in immigration legislation that link continued possession of legal status to formal employment and vice versa, especially in southern Europe (see Chaps. 2 and 3). On the other hand, demand for low-skilled labor and the extent of the informal economy in southern Europe also make informal employment easier to access and irregular status less burdensome, meaning that irregular status may also be negatively associated with transitions to unemployment.

\subsection{Data and Methods}

This chapter uses the MAFE-Senegal data described in Chaps. 1 and 3. This chapter draws on the retrospective biographical data on Senegalese migrants' economic activities, union formation, child bearing, and administrative history. While the earlier chapters outline the sampling and data collection procedures, it is useful to note for the purposes of this chapter that women were oversampled in all locations to ensure sufficient numbers for separate gender analyses.

\subsubsection{The Analytic Sample}

The sample for the analysis in this chapter includes individuals who have migrated at least once to Italy, France or Spain while they were greater than 18 (see Chap. 1 for more details on the MAFE sampling and selection scheme). Returned migrants interviewed in Senegal are included if they spent at least a year in at least one of the destination countries. Individuals can have multiple periods of residence in or "trips" to one or more of these destination countries. The analytic sample thus comprises 7881 person-years and 727 trips: 3548 person-years in France (287 individual trips), 2258 person-years (221 individual trips) in Italy, and 2075 person-years (219 individual trips) in Spain. Sixty-five percent of respondents had only one trip, and an additional $21 \%$ had two trips.

The MAFE-Senegal data are well suited to this investigation because the multisited nature of the data collection reduces potential biases stemming from selective emigration and return (Massey 1987) through the inclusion of current and returned migrants. The data, in addition to reconstructing migrants' family and labor-market trajectories, also include extensive information on migrants' legal statuses during each year of residence abroad. Lack of such data on legal status has been a major 
impediment to investigations of the effect of legal status on labor-market performance of immigrants in Europe (Amuedo-Dorantes et al. 2013; González-Ferrer 2011a). The MAFE project also interviewed both women and men, allowing investigations of differential incorporation by gender. The sample includes $376(57 \%)$ men and 286 (43\%) women, although the weighted share of men is $70 \%$.

\subsubsection{Outcome Variables}

The analysis examines Senegalese migrants' labor-market performance in France, Italy, and Spain by focusing on three different outcomes: economic activity status during the year of arrival, transitions into (for women) or out of (for men) employment, and occupational category conditional on being employed.

\section{Economic Activity}

The MAFE questionnaire asked respondents to identify their principal activity for each period of their lives. Respondents could answer that they were studying, economically active, unemployed, homemaking, retired, or otherwise inactive. For this analysis, a categorical variable indicates whether migrants were working, unemployed, or economically inactive, with the last category including students, homemakers, retirees, and other inactive individuals. Table 4.2 presents weighted descriptive statistics for the sample and shows statistically significant bivariate gender disparities in economic activity during the year of arrival: $2.7 \%$ of women and $8.5 \%$ of men were unemployed $(p<.01), 38 \%$ of women and $76 \%$ of men were employed $(p<.001)$, and $59 \%$ of women and $15 \%$ of men were inactive $(p<.001)$ during the first year in destination.

Although this last category is heterogeneous across the entire sample, it is strongly gendered: $85 \%$ of men who were inactive during the year of arrival were students and $91 \%$ of all economically inactive person-years among men were spent studying, while $73 \%$ of women who were inactive during the year of arrival were homemakers and $77 \%$ of all economically inactive person-years among women were spent homemaking. Men never declared being a homemaker and were retired or otherwise inactive during 9\% of person years. Twenty-three percent of inactive women were students during the year of arrival but studying only made up 16\% of all inactive person-years among women.

The analysis uses two additional variables based on the economic activity variable: a variable capturing transitions into unemployment, if the categorical employment variable equaled "unemployed" at time $t+1$; and a variable capturing transitions into employment, if the categorical employment variable equaled "employed" at time $t+1$. These indicators serve as dependent variables in models for dynamic transitions into unemployment for men and into employment for women. 


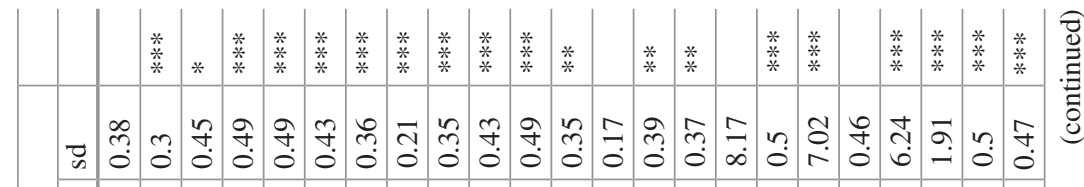 \\ 专

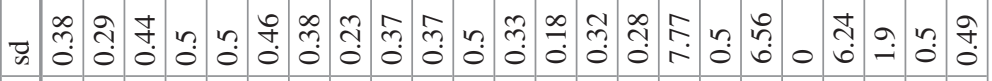

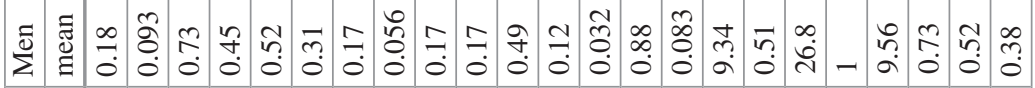
光

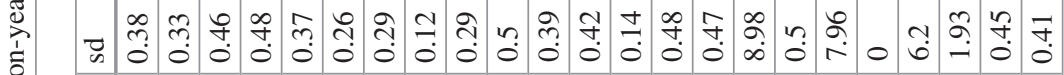

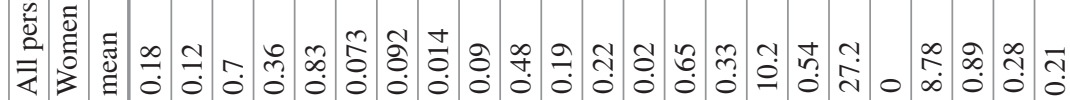

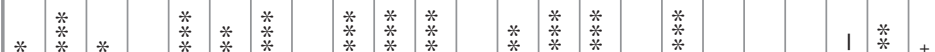

I

吾 I

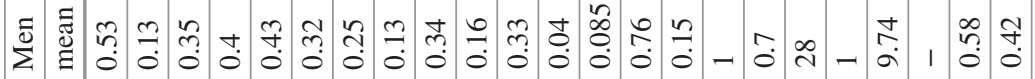

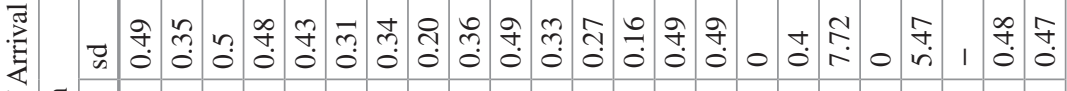

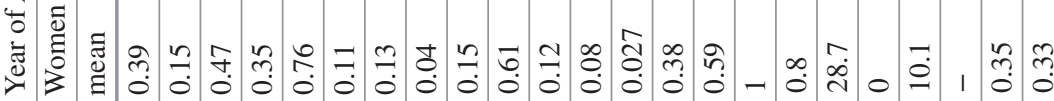

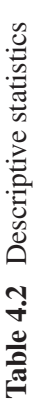

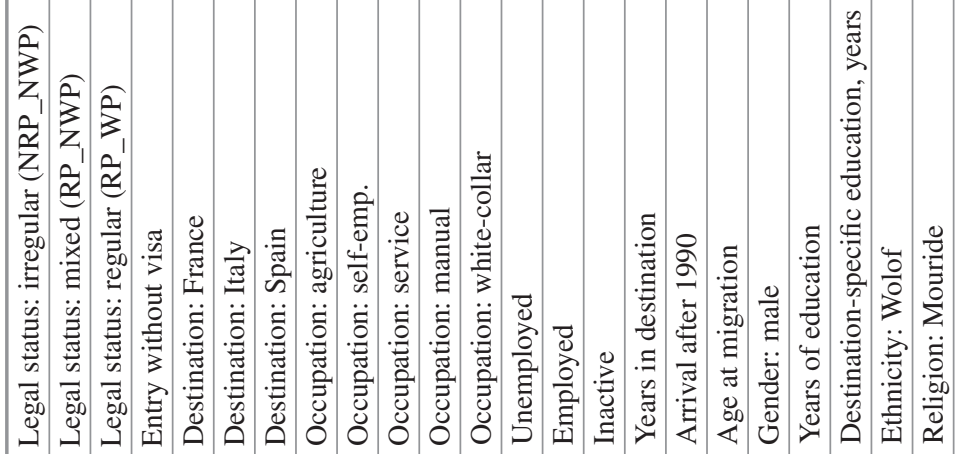




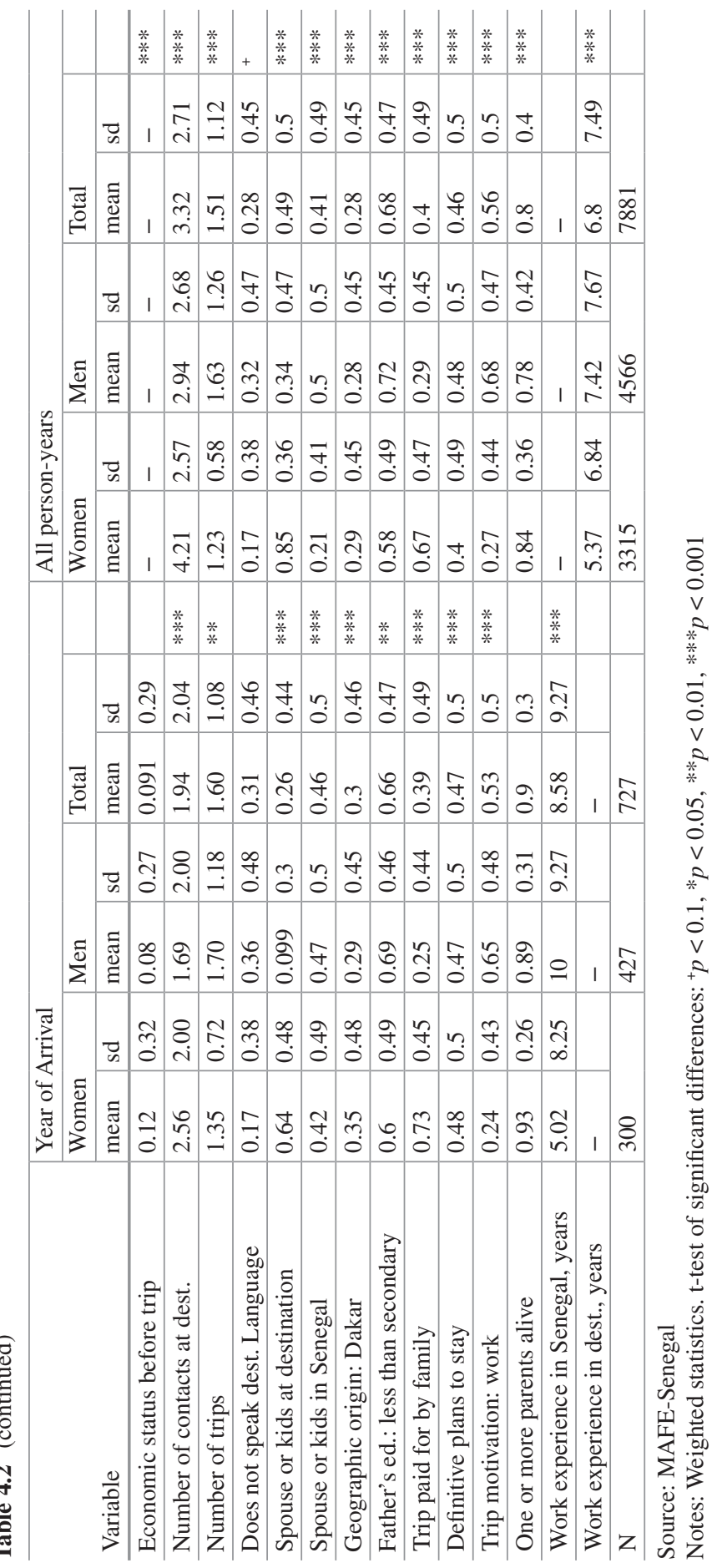




\subsubsection{Predictor Variables}

\section{Legal Status and Context of Reception}

The key predictors in each model are variables measuring legal status. The analyses use the same typology of legal-status categories as presented in Chap. 3 and briefly restated here. A dichotomous variable indicates if a migrant entered the destination country at the start of the current trip with or without a visa. Annual indicators of residence and work permits combine to form a categorical variable capturing both forms of authorization. This categorical variable takes the values of "NRP_NWP" for migrants who lack both a residence permit and a work permit ("fully irregular status"), and "RP_WP" for migrants who possess both a residence permit and a work permit ("fully regular status"). "RP_NWP" indicates that migrants have a residence permit but lack a work permit ("mixed status"), a situation common among students and reunified family members in France, Italy, and Spain (Mezger and González-Ferrer 2013). While the combination of lacking a residence permit and possessing a work permit is theoretically possible and is declared in $4 \%$ of person years by Senegalese migrants, the immigration policies of the receiving countries have almost always made work permits conditional on possessing a permit to reside lawfully or possession of work permits have automatically made such residence lawful (see Chap. 2), and migrants may have declared this status because of recall bias or incomplete understanding of their statuses. The analyses thus exclude person-years in which migrants declared "NRP_WP" status from the analytic sample for this investigation.

Table 4.2 indicates that, during the first year in destination, Senegalese women are more likely to have fully regular status than men, while men are more likely to have fully irregular status; the proportions of women and men with mixed status during the first year are not statistically different. Approximately $17 \%$ of all personyears among both men and women display fully irregular status, with no significant gender difference. Women are significantly more likely to spend time in mixed status, accounting for $12 \%$ of their person-years compared to $9.3 \%$ of men's. Women spend a slightly higher proportion of person-years in fully regular status. The fully-regular category serves as the reference category in regression models. Regarding visa status, there is no statistically significant difference in the proportion of men and women arriving without visa.

The other key predictor variable is the context of reception, as captured by indicators for country of residence. Table 4.2 shows that women tend to be concentrated in France during the year of arrival: $76 \%$ of Senegalese women migrants live in France, as compared to $11 \%$ in Italy and $13 \%$ in Spain. Only $43 \%$ of trips for men start in France, with $26 \%$ starting in Italy and 22\% starting in Spain. A similar pattern for women holds across all person years: they are overwhelmingly concentrated in France ( $83 \%$ of person-years). Men also tend to spend more time overall in France across all person-years (52\%), while they spend $31 \%$ of person-years in Italy and $17 \%$ in Spain. 


\section{Location of Spouse/Partner}

A dichotomous variable indicates whether or not the migrant has a spouse and/or children living in the same destination. According to Table 4.2, 64\% of Senegalese women declared having a spouse and/or a child in the same destination at the year of arrival, while only $10 \%$ of men declared the same. A similar variable indicates whether or not the migrant has a spouse and/or children residing in Senegal: $42 \%$ of women and $47 \%$ of men declared having these family members at origin. An additional dichotomous variable indicates whether or not the migrant has at least one parent still alive in Senegal. All of the family variables are time-varying (Obucina 2013).

\section{Human, Social, and Migration-Specific Capital}

Variables indicating human capital during the year of arrival include years of education, ability to speak the language of the destination country (does not speak vs. speaks well or gets by), age at the time of the start of the trip, and years of work experience in Senegal prior to migration. Time-varying human-capital indicators include the number of years spent in the destination, the cumulative years of education acquired in the destination, and the cumulative years of work experience acquired in the destination; language ability can also vary over time. A variable measuring the number of family members and other close members of the migrant's personal network that live in the same destination country captures social capital and can vary over time. The number of trips a migrant has made indicates migrationspecific capital. Other variables capture migrants' motivations, which could be considered a kind of cognitive capital: a dichotomous variable indicates whether or not work was the main motivation for migration, and another dichotomous variable indicates whether or not the migrant plans to stay definitively in the current destination.

\section{Context of Exit}

Variables indicating the migrant's social and cultural context of exit include ethnicity (Wolof vs. other), religion (Mouride vs. other), and geographic origin (Dakar vs. other). Variables indicating the migrant's economic context of exit include selfreported economic status prior to migration (more than sufficient for daily needs and better than others in the same place vs. other), father's educational level (less than secondary school vs. secondary school or more, which is proxy for social class), and financial participation of family members in the financing of the current trip (yes vs. no). 


\subsubsection{Models}

Separate models for men and women are estimated for the outcomes of economic activity status and transitions to and from employment. Due to sample-size restrictions, separate models by gender for the occupational status outcome are not estimable; this model will thus include interactions between the gender and other key predictors.

\section{First-Year Economic Activity}

I estimate multinomial logistic regression models predicting economic activity status during the first year of residence in France, Italy, or Spain as specified by the following equation:

$$
\ln \left(\frac{\operatorname{Pr}\left(\text { Activity }_{i t 1}=i\right)}{\operatorname{Pr}\left(\text { Activity }_{t 1}=\text { Unemployed }\right)}\right)=\alpha+X_{1} \beta_{1}+X_{2} \beta_{2}+\left(X_{1} \times X_{2}\right) \beta_{3}+X_{4} \beta_{4}+X_{5} \beta_{5}+X_{6} \beta_{6}
$$

where $i$ indexes activity states unemployed, employed, and inactive at time $t=1 . X_{1}$ is a vector of indicators of legal status (visa and residence/work authorization), $\boldsymbol{X}_{2}$ is a vector of indicators of country of residence, and $\boldsymbol{X}_{1} \times \boldsymbol{X}_{2}$ represents the interaction between legal status and country of residence. $\boldsymbol{X}_{\mathbf{4}}$ is a vector of variables indicating human, social, and migration-specific capital. $\boldsymbol{X}_{\mathbf{5}}$ is a vector of variables indicating family links, and $\boldsymbol{X}_{\mathbf{6}}$ is a vector of variables capturing the migrant's context of exit. All variables in this model are measured at time $t=1$, the year in which the migrant arrives at the destination. I estimate separate models for men and women.

\section{Transitions into and out of Employment}

Discrete-time survival models estimate the risk of transitions either into or out of employment. The following model estimates the first transition out of employment for men:

$$
\ln \left(\frac{\operatorname{Pr}\left(\text { Enemployed }_{t+1}\right)}{1-\operatorname{Pr}\left(\text { _nemployed }_{t+1}\right)}\right)=\alpha+X_{1 t} \beta_{1}+X_{2 t} \beta_{2}+\left(X_{1 t} \times X_{2 t}\right) \beta_{3}+X_{4 t} \beta_{4}+X_{5 t} \beta_{5}+X_{6 t} \beta_{6}+X_{7 t} \beta_{7}
$$

where the outcome variable is a dichotomous indicator of unemployment at time $t+1$. All of the predictor vectors are as in the first model, except that some can vary over time; these are thus measured at time $t$. $\boldsymbol{X}_{\mathbf{4}}$ additionally includes the number of years spent at the destination, the cumulative time spent in employment or in formal 
studies at the destination, the prestige score of the migrant's current job, and a dichotomous variable indicating the activity status of the migrant in year $t$ (inactive vs. employed). $\boldsymbol{X}_{7}$ is a vector of time-counting variables indicating the duration at risk for falling into unemployment (number of years) and the number of activity spells. Only men who are employed or inactive are subject to the risk of falling into unemployment, and exit the risk set either through censoring or becoming unemployed.

The following model estimates the first transition into employment for women:

$$
\ln \left(\frac{\operatorname{Pr}\left(\text { Employed }_{t+1}\right)}{1-\operatorname{Pr}\left(\text { Employed }_{t+1}\right)}\right)=\alpha+X_{1 t} \beta_{1}+X_{2 t} \beta_{2}+\left(X_{1 t} \times X_{2 t}\right) \beta_{3}+X_{4 t} \beta_{4}+X_{5 t} \beta_{5}+X_{6 t} \beta_{6}
$$

where the outcome variable is a dichotomous indicator of employment at time $t+1$. The predictors are identical to those in model 2, with the exception of the employment-related variables, which are unmeasured for women because this model examines the risk of first entry into employment; the model for women does, however, include a variable indicating cumulative work experience in Senegal. Only women who are inactive or unemployed are subject to the risk of becoming employed, and exit the risk set either through censoring or becoming employed.

\subsection{Results}

\subsubsection{Gender, Partner Location, and Legal Status}

The MAFE data show a clear connection between partner location and the varying legal status configurations across countries as outlined in Table 4.1 that are indicative of family reunification for women in different. Figure 4.1 shows the legal status of Senegalese men and women during the year of their arrival in Europe, by their destination and the location of their partners. Women who rejoin a partner in France are overwhelmingly likely to have fully regular legal status during their year of arrival: $63 \%$ of women with a partner in France possess this status, compared to only $33 \%$ of women in France without a partner in that location. Senegalese women with fully regular status in France and a spouse in that destination are thus likely to have accessed this status through legal channels of family reunification as France's immigration policies allow both residence and work authorizations for reunified spouses.

In contrast, Senegalese women going to Spain or Italy to rejoin a partner are likely not to have fully regular status, and results are indicative of the operation of both legal and irregular channels of reunification. Mixed status-possessing a residence permit but lacking a work permit-is the most common for Senegalese women with a partner in Italy, indicative of family reunification in a legal context 


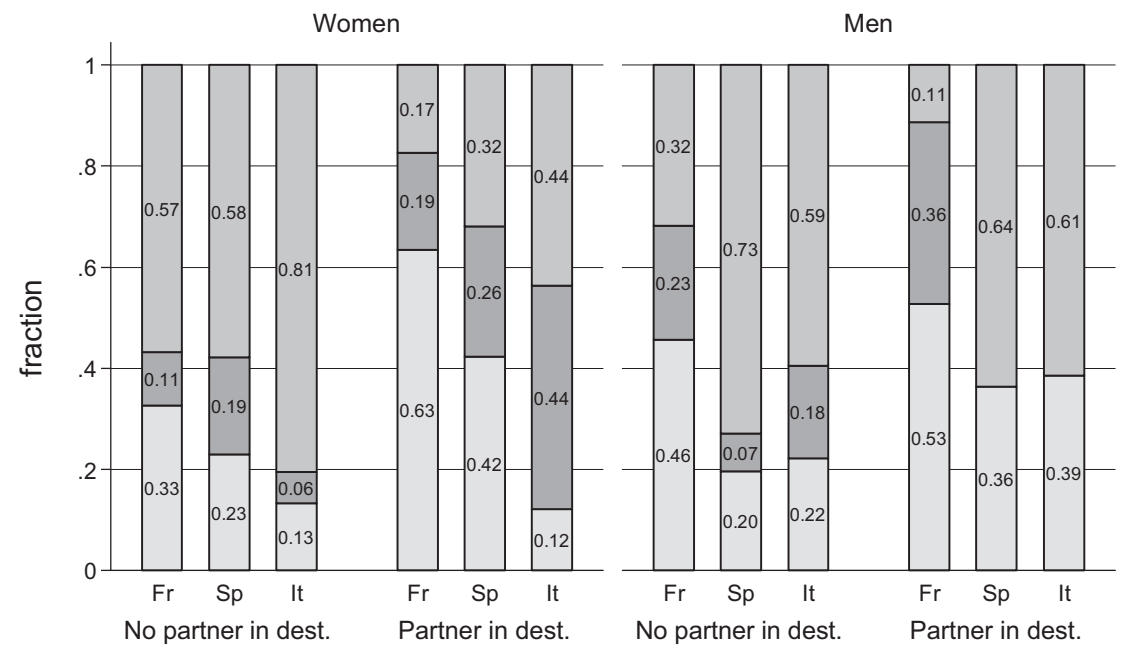

$\square$ Fully regular

Mixed

Fully irregular

Fig. 4.1 Legal status at arrival by gender, destination, and location of spouse. (Source: MAFESenegal. Notes: Weighted data)

that imposes a waiting period. Irregular status is also common among women joining a partner in Italy, which suggests the operation of an irregular-reunification pathway. In Spain, more than half of Senegalese women rejoining a partner report having either mixed or fully irregular status upon arrival, indicating the prevalence of both the legal channel of family reunification that imposes a work-authorization waiting period (giving rise to mixed status) and an irregular pathway of reunification. The figure suggests that the distribution of legal statuses during the year of arrival among Senegalese men conditional on partner location does not vary as much as for women.

Examination of women's motivations for migration along with the location of their partner and elucidates the link between family-reunification policies and women's first-year legal status. Figure 4.2 shows that women who migrate for family reasons and join a partner at destination are likely to have the configurations of legal status indicative of family reunification (fully regular status in France and mixed status in Italy and, to a slightly lesser extent, Spain). In contrast, women with a partner at their destination who migrate for work reasons are far more likely to have fully irregular status in all destinations, indicating a willingness to circumvent legal channels of family reunification that may inhibit their ability to work upon arrival. These descriptive findings are suggestive of the link between women's legal status during the year of arrival and the gendered channel of family reunification. 


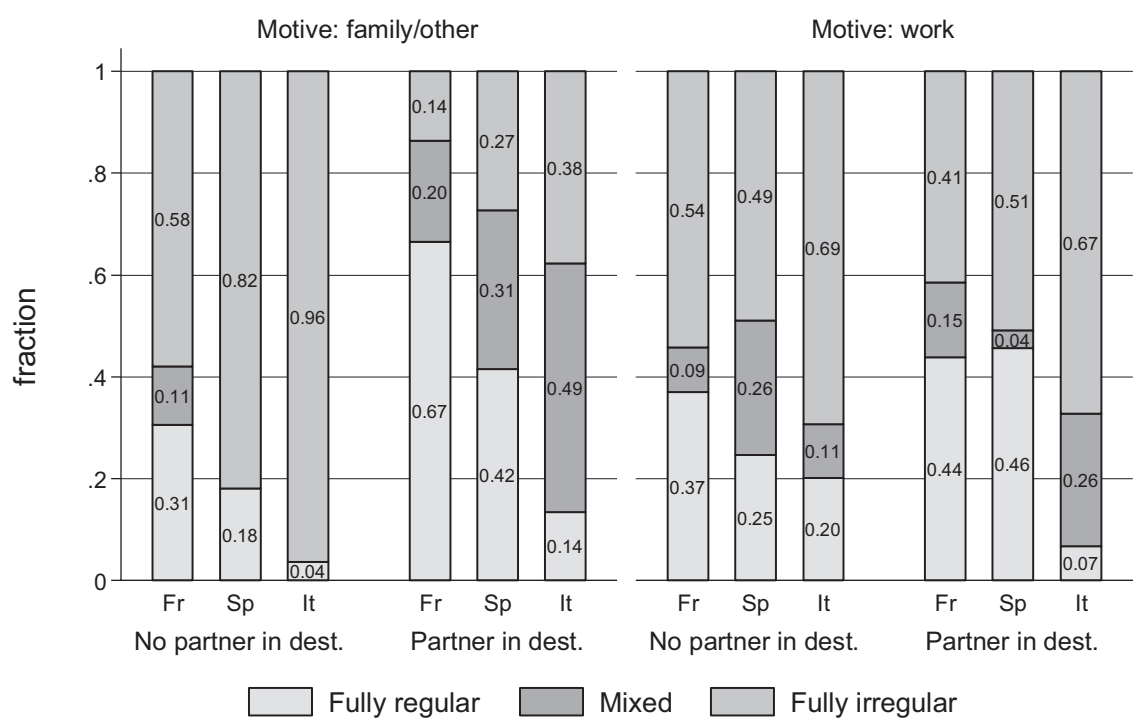

Fig. 4.2 Legal status among Senegalese women during year of arrival, by destination, partner location, and migration motivation. (Source: MAFE-Senegal. Notes: Weighted data)

\subsubsection{First-Year Economic Activity}

Legal status was hypothesized to have different effects for Senegalese men's and women's economic status during the year of arrival at destination. Descriptive statistics largely support this view, with much greater variation in economic activity across women's legal statuses than men's.

The descriptive statistics in Table 4.2 demonstrate differences in Senegalese men's and women's labor-force participation during their year of arrival at destination: women are more likely to be inactive, and, among those in the labor force, men are more likely to be unemployed. Figures 4.3 and 4.4 show additional variation in labor-force participation and employment among both men and women by their legal status upon arrival and their destination country. The first figure shows that Senegalese men in France across all legal statuses tend to be inactive more frequently than Senegalese men in Italy or Spain, reflecting the fact that there is a significant flow of Senegalese students to France given the colonial and linguistic links between the two countries. Male migrants also tend to have a higher rate of inactivity in Spain and Italy when they have a mixed status upon arrival. A very small proportion of Senegalese men with fully regular status are inactive in Italy or Spain. Unemployment rates among men are quite low across countries and legal statuses. Having fully irregular legal status is positively associated with unemployment in Italy during the year of arrival, while a higher risk of unemployment is associated with having a mixed status in Spain. 


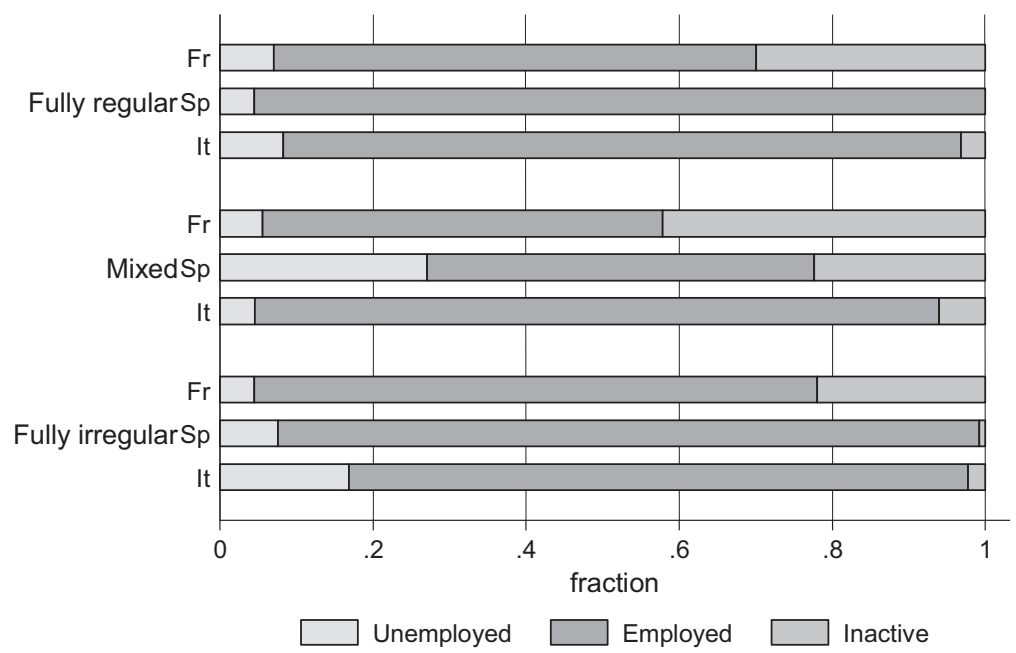

Fig. 4.3 First-year activity status by legal status and country of residence, Senegalese men. (Source: MAFE-Senegal. Weighted data)

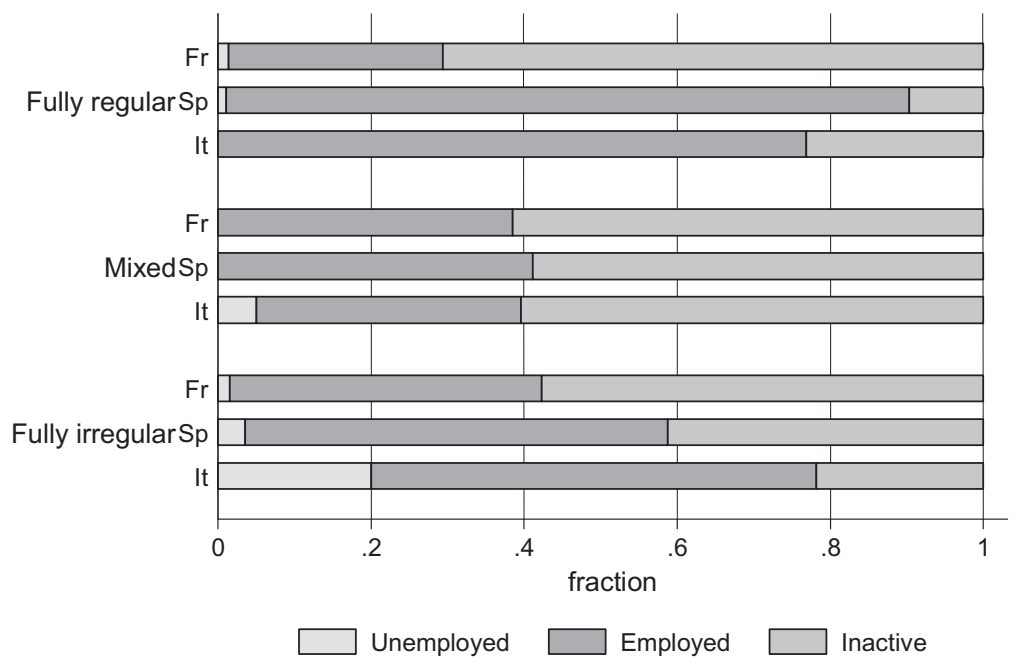

Fig. 4.4 First-year activity status by legal status and country of residence, Senegalese women. (Source: MAFE-Senegal. Weighted data)

Figure 4.4 shows a different pattern for women: rates of labor-force participation and employment vary strongly by country of residence and legal status. Senegalese women with mixed status (RP_NWP) have the highest rates of inactivity, and these rates are higher in Spain and Italy than in France. Among Senegalese women in France, those with fully irregular status have the lowest rate of inactivity, while 
those with fully regular status have the highest rates of inactivity. The pattern for Italy and Spain is reversed: female migrants with fully irregular or fully regular statuses have the lowest rates of inactivity. As with male Senegalese migrants, having fully irregular status in Italy during the year of arrival seems to increase the risk of unemployment for those women in the labor market, especially compared to female migrants with fully regular status in Italy, who experience little unemployment during the year of arrival. Female migrants in Spain and France seem to face low levels of unemployment across legal statuses.

Results from the multinomial regression models for men and women also suggest that the effect of legal status on first-year economic activity is gendered. Table 4.3 displays results from the separate multinomial logistic regressions of firstyear activity status for Senegalese men and women. For Senegalese men, having mixed legal status (RP_NWP) is positively associated with being inactive: compared to male migrants with fully regular status, male migrants who lack only a work permit are six percentage points more likely to be inactive. Conversely, legal status does not have a statistically significant association with probabilities of working or being unemployed during the year of arrival for men.

While the effect of legal status on men's first-year activity is limited, legal status is more consistently associated with first-year activity for Senegalese women. Having mixed (RP_NWP) status is positively associated with being inactive compared to having fully regular status (RP_WP), although only at $p<.1$, and this effect is offset by a negative association between mixed status and the probability of employment. Women with fully irregular (NWP_NRP) status face a higher risk of unemployment compared to women with fully regular status (RP_WP): lacking both residence and work authorization is associated with a five-percentage-point increase in the probability of being unemployed compared to being inactive or employed. Entering the country without a visa has no effect on any of the outcomes for either men or women. The effect of legal status on first-year economic activity thus varies by gender. Lacking only a work permit increases the probability of being inactive for both men and women, indicating the role of student migration for men and family reunification for women. Other predictors in this model lend credence to this interpretation. Years of education is significantly positively related to inactivity and negatively related to employment for men, while years of work experience in Senegal is associated with increased employment and decreased inactivity. Acquired human capital thus has opposite effects: those male Senegalese migrants that are more highly educated tend to be economically inactive students during their year of arrival, while those with acquired employment experience tend be economically active and working.

Other predictors in the model are also suggestive of distinctive profiles of labormarket participation in keeping with family reunification for women. Among women, those who indicated work as the primary motivation for their migration are 17 percentage points less likely to be inactive than those women who indicated family as the primary motivation. In addition, women who intend to stay definitively at 


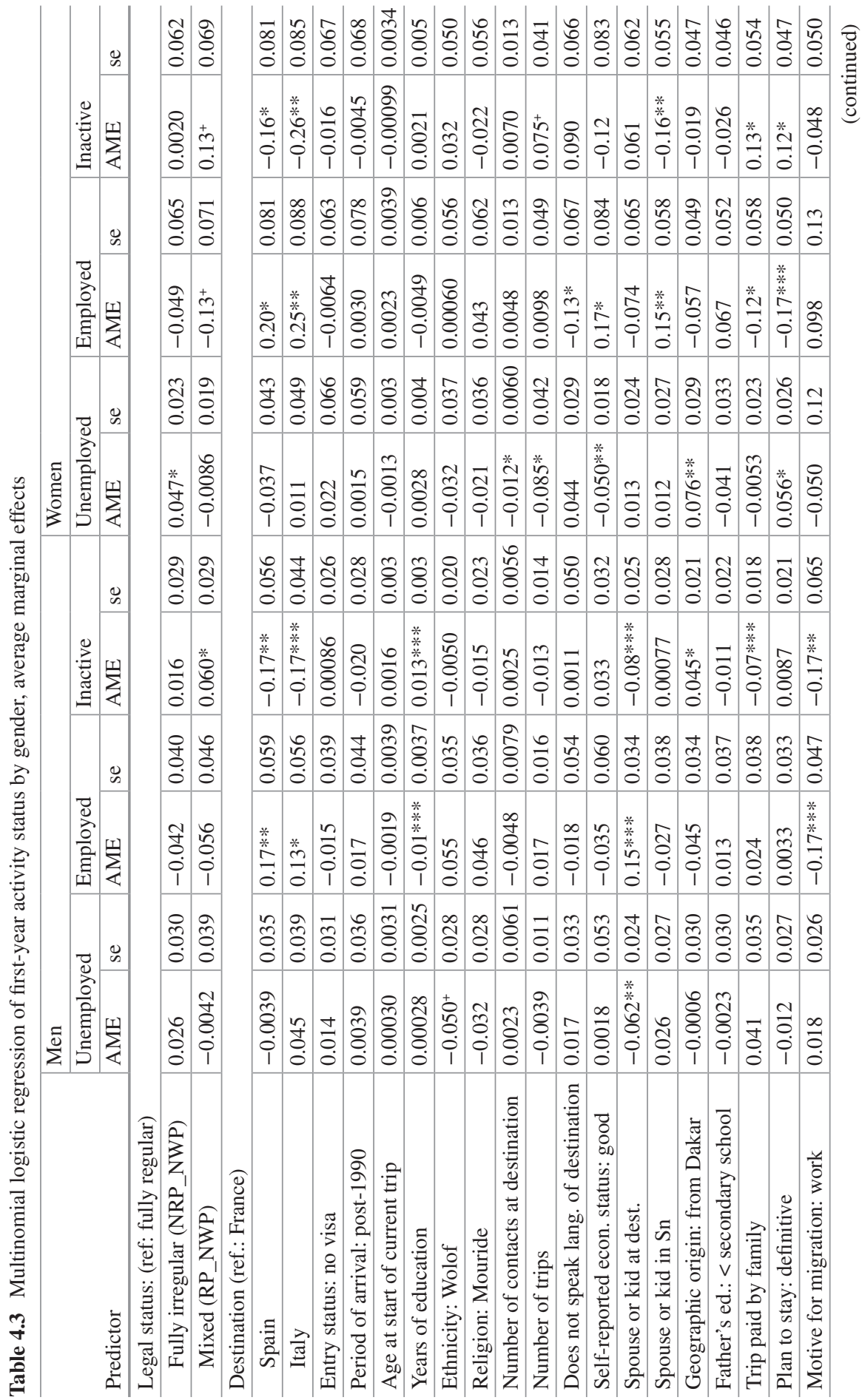




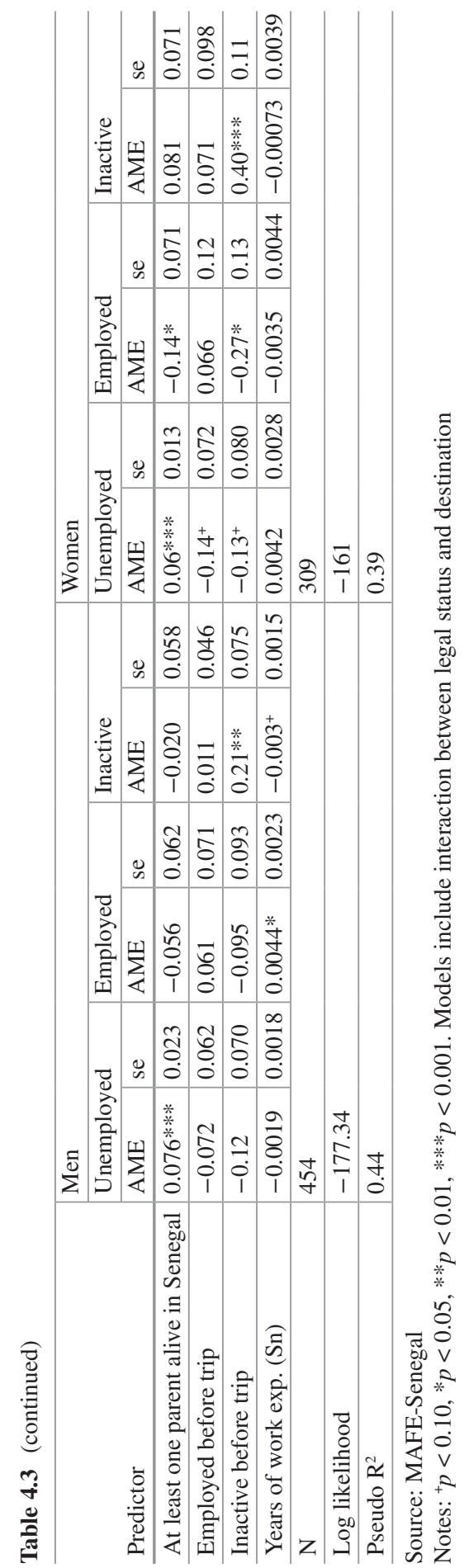


the destination and those whose families contributed financially to the trip ${ }^{1}$ are more likely to be inactive and less likely to be working. These associations between motivations, intentions, family financial participation and the likelihood of inactivity are indicative of family reunification. Interestingly, having a spouse and/or children at the destination had no direct effect on women's first-year economic activity net of legal status and other predictors, suggesting that direct measures of women's legal status and motivations are more important predictors of economic participation.

Other predictors were indicative of autonomous-migration profiles. Those women with a spouse or children in Senegal are less likely to be inactive and more likely to be working, indicating that they are probably independent pioneer migrants who migrated, in part, to support family in Senegal through working in Europe; for men, having a spouse or child in the same destination is positively predictive of employment and negatively predictive of both inactivity and unemployment. While legal status and other predictors define distinctive profiles for inactive migrants among both men and women, legal status is not related to employment for active men. It does seem, however, to structure women's employment chances: female migrants with fully irregular status are more likely to be unemployed.

The effects of legal statuses vary across destinations, but more so for women than for men. Table 4.3 also shows significant variation in the probabilities of firstyear activity status between contexts of reception. For both men and women, compared to their compatriots in France, Senegalese in Italy and Spain are less likely to be inactive and more likely to be employed during their first year of residence. Country of residence does not have a significant relationship with unemployment for either men or women. Given the variation in first-year activity status by both legal status and country of residence, the model includes an interaction between these predictors that can help us examine how the effect of legal status varies by country of residence. Table 4.4 displays the average marginal effects of legal status by country of residence for both men and women. The top panel of the table shows that this interaction does not produce statistically significant variation in the effects of legal status for men.

For Senegalese women, on the other hand, variation in the effect of legal statuses on first-year economic activity across destinations is consistent with different configurations of legal status for reunified migrants in different countries. The bottom panel of Table 4.4 shows that the effects of legal status do vary by destination for women. For women in France, not having fully regular legal status is associated with a decrease in the probability of being inactive: women with mixed (RP_NWP) status are 21 percentage points less likely to be inactive than women with fully regular status, and women with fully irregular status are 24 percentage points less likely to be inactive than women with fully regular status. These lower inactivity rates for women without fully regular status in France are offset by a relative increase in the

\footnotetext{
${ }^{1}$ Previous empirical research with the MAFE data has shown that husbands overwhelmingly participate in the decision-making for their wives' migration (Toma 2012). Family financial contributions to women's migration also come mostly from husbands: $74 \%$ of Senegalese women who reported such financial contributions received them from their partners.
} 


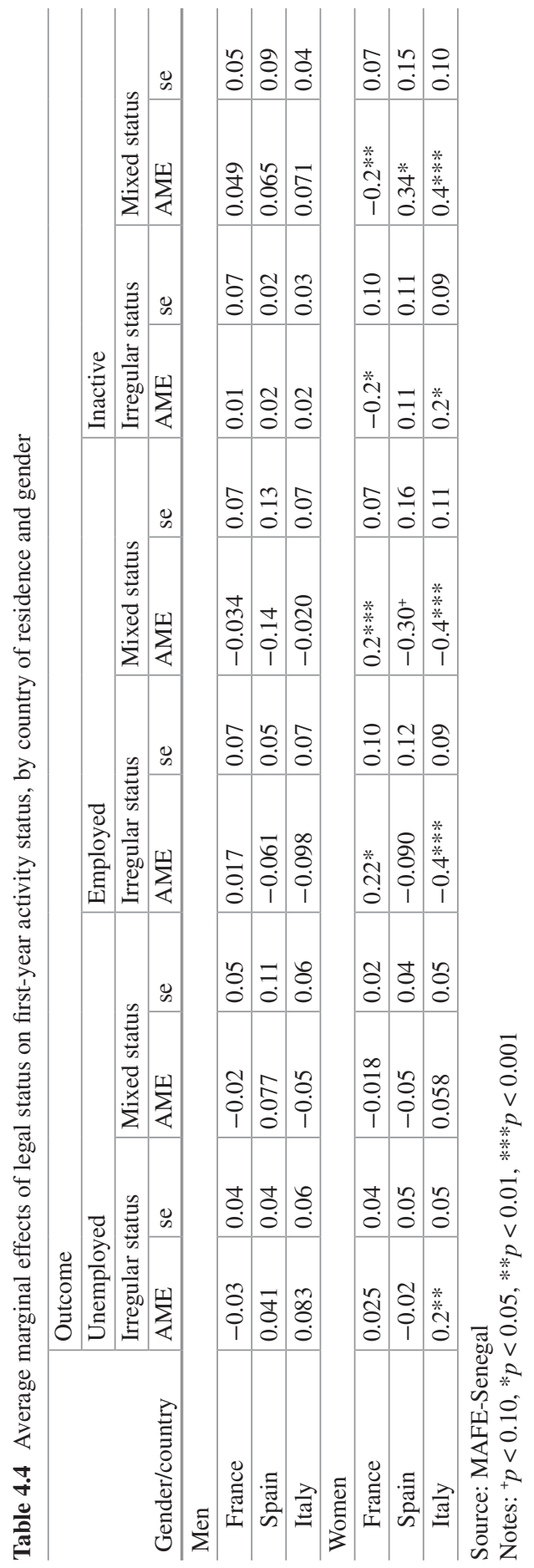


probability of employment: women with mixed or fully irregular status have employment probability roughly 22 percentage points higher than fully regular women in France, while legal status has no effect on unemployment for women in France. These findings are indicative of their migration via the legal reunification channel, which confers fully regular legal status. The lower activity rate of these likely reunifiers supports previous findings that reunified women are less likely to participate in the labor force because of administrative and economic dependency.

The association between legal status and inactivity among Senegalese women in Italy and Spain is also consistent with legal channels of family reunification. Women with mixed legal status in Italy and Spain are more likely to be inactive than women in those countries with fully regular status. These higher inactivity rates translate into a negative effect of mixed legal status on employment in both of these countries. As in the case of France, these results are consistent with the channel of family-reunification in these countries. Italy and Spain differ from France in the specific configuration of legal status associated with the family reunification channel: they both impose a waiting period on the reunified spouses' applications for a work permit. The lack of a work permit among otherwise legal migrants is a sign of reunification and limited rights of formal participation, which result in lower participation in the labor force for reunified Senegalese women in southern Europe.

Senegalese women with legal statuses upon arrival that are indicative of nonreunification pathways are more likely to attempt to work. Mixed or irregular statuses are associated with employment among Senegalese women in France, indicating that students (who generally lack a work permit) and migrants with irregular status are more likely to work than reunified spouses, and this in spite of their lack of formal authorization to do so. In contrast, having fully regular status is predictive of employment in both Italy and Spain; unlike in France, where this status is associated with family reunification, this association suggests that Senegalese women might be able to access formal channels of labor recruitment, perhaps through quotas for domestic workers.

These results show a fairly simple pattern: Senegalese women who have legal statuses consistent with family reunification tend to have higher rates of inactivity than Senegalese women with other legal statuses. The specific configuration of legal statuses associated with reunification varies across destinations, though, giving rise to different associations between particular statuses and the probability of inactivity in different countries. These results also strongly suggest the heterogeneity of Senegalese women's legal statuses and a systematic association between nonreunification statuses - even those that do not include formal residence and/or work authorization - and the propensity to be employed upon arrival. In contrast, the labor-force participation and employment of Senegalese men is not as sensitive to variation across legal statuses or destinations, indicative of a near-universal motivation to work (with the possible exception of male students in France). 


\subsubsection{Transitions out of Employment for Men}

The dynamic model of transitions into unemployment for Senegalese men shows that lack of fully regular legal status does not increase the likelihood of losing a job, nor does possessing fully regular status increase the likelihood of keeping a job. Table 4.5 presents results for the discrete-time survival analysis of transitions into unemployment for men. These results show that mixed or fully irregular legal status is not associated with a statistically significantly different risk of falling into unemployment compared to fully regular status, nor is having entered without a visa predictive of this transition. Senegalese men in Spain face a 2.3 percentage-point higher risk of falling into unemployment than Senegalese men in France. Interactions between legal status and country of residence do not show any significant effects. Formal, legal barriers to transitions out of employment thus seem to be limited for Senegalese men.

Indeed, few predictors in this model have a significant association with the risk of falling into unemployment, which is due in part to the rarity of the transition: only $8 \%$ of subjects eventually fail, and the survivor function after 7 years-the median duration at risk for unemployment-is $95 \%$. The risk of transitioning to unemployment is marginally higher for more recent arrivals, perhaps suggesting secular declines in labor-market conditions. The risk of unemployment also increases with the number of activity spells and the prestige score of jobs, indicating that frequent change of jobs and having a "better" job increase the likelihood of becoming unemployed. This pattern may indicate that Senegalese men may indeed experience a tradeoff between employment and job quality: bad jobs are easier to get and to hold on to than good jobs, as is suggested by the literature (Fullin and Reyneri 2011). Conversely, male migrants whose families participated in financing their trip are less likely to become unemployed, indicating that such migrants may be more likely to keep jobs because, in part, they face pressure to "pay off" this investment through remittances (Chort et al. 2012).

\subsubsection{Transitions into Employment for Women}

Transitions to employment for women are suggestive of the eventual transformation of reunified spouses into labor migrants. The probability of a transition into employment among women is much higher than the transition examined for men: after the median duration of time at risk for becoming employed (4 years), the survivor function is only $62 \%$; the figure falls to $30 \%$ after 10 years. The baseline risk for women is thus quite high, indicating that the majority eventually experience a transition into economic activity.

The dynamic model of women's transitions into employment indicates that secure legal status is a strong predictor of eventual work. Table 4.5 presents average marginal effects for the discrete-time survival analysis of transitions into employment 
Table 4.5 Discrete-time survival analysis of transitions into and out of employment by gender, average marginal effects

\begin{tabular}{|c|c|c|c|c|}
\hline \multirow[b]{3}{*}{ Predictor } & \multicolumn{2}{|l|}{ Men } & \multicolumn{2}{|l|}{ Women } \\
\hline & \multicolumn{2}{|c|}{ Unemployment } & \multicolumn{2}{|c|}{ Employment } \\
\hline & AME & se & AME & se \\
\hline \multicolumn{5}{|l|}{ Legal status (ref.: fully regular) } \\
\hline Fully irregular (NRP_NWP) & -0.0039 & 0.0073 & -0.043 & 0.044 \\
\hline Mixed (RP_NWP) & -0.0085 & 0.0091 & $-0.10 * * *$ & 0.031 \\
\hline \multicolumn{5}{|l|}{ Destination (ref.: France) } \\
\hline Spain & $0.023^{*}$ & 0.0089 & 0.0097 & 0.053 \\
\hline Italy & 0.011 & 0.0089 & -0.072 & 0.047 \\
\hline Entry status: no visa & -0.00031 & 0.0037 & 0.093* & 0.038 \\
\hline Years in dest. & -0.0079 & 0.0068 & 0.0050 & 0.0097 \\
\hline Duration at risk & 0.00049 & 0.0027 & 0.0076 & 0.0095 \\
\hline Period of arrival: post-1990 & $0.0092^{+}$ & 0.0049 & $0.10^{* * *}$ & 0.027 \\
\hline Number of act. spells & $0.022 * * *$ & 0.0036 & $0.064 * * *$ & 0.015 \\
\hline Age at start of current migration spell & -0.00060 & 0.00040 & -0.0014 & 0.0018 \\
\hline Years of education & -0.00024 & 0.00056 & $0.0072 * *$ & 0.0027 \\
\hline Ethnicity: Wolof & 0.0033 & 0.0064 & $-0.034^{+}$ & 0.021 \\
\hline Religion: Mouride & -0.0078 & 0.0060 & -0.026 & 0.042 \\
\hline Years of ed. in dest. & 0.0070 & 0.0070 & -0.0037 & 0.0073 \\
\hline Number of contacts at destination & $-0.0019^{+}$ & 0.0011 & $0.0095 *$ & 0.0047 \\
\hline Number of trips & -0.00016 & 0.00100 & 0.043 & 0.027 \\
\hline Does not speak language of destination & -0.0068 & 0.0053 & -0.0078 & 0.047 \\
\hline Work exp. at dest. & 0.0086 & 0.0080 & - & - \\
\hline Unemployed & - & - & \multicolumn{2}{|l|}{ Ref. } \\
\hline Employed & \multicolumn{2}{|l|}{ Ref. } & - & - \\
\hline Inactive & -0.0031 & 0.0089 & -0.093 & 0.067 \\
\hline Manual occupation & 0.0030 & 0.0045 & - & - \\
\hline ISEI & $0.00028 *$ & 0.00013 & - & - \\
\hline Spouse or kid at dest. & 0.0019 & 0.0037 & 0.0063 & 0.036 \\
\hline Spouse or kid in Sn & -0.0047 & 0.0046 & 0.038 & 0.044 \\
\hline Geographic origin: from Dakar & -0.00082 & 0.0044 & 0.023 & 0.031 \\
\hline Father's ed.: < secondary school & -0.0044 & 0.0036 & 0.0096 & 0.027 \\
\hline Trip paid by family & $-0.013 * *$ & 0.0049 & 0.0012 & 0.028 \\
\hline Plan to stay: definitive & 0.0035 & 0.0040 & $0.055^{+}$ & 0.029 \\
\hline Motive: work/better life & -0.0052 & 0.0038 & 0.045 & 0.034 \\
\hline Work exp. in Sn (years) & - & - & $0.0055^{* *}$ & 0.0017 \\
\hline Self-reported econ. status: good & - & - & -0.018 & 0.051 \\
\hline $\mathrm{N}$ (person-years) & \multicolumn{2}{|l|}{4010} & \multicolumn{2}{|l|}{819} \\
\hline Events & \multicolumn{2}{|l|}{36} & \multicolumn{2}{|l|}{90} \\
\hline Log likelihood & \multicolumn{2}{|l|}{-131.21} & \multicolumn{2}{|l|}{-231.49} \\
\hline Pseudo $\mathrm{R}^{2}$ & \multicolumn{2}{|l|}{0.36} & \multicolumn{2}{|l|}{0.18} \\
\hline
\end{tabular}

Source: MAFE-Senegal

Notes: ${ }^{+} p<0.10,{ }^{*} p<0.05, * * p<0.01, * * * p<0.001$. Models include interaction between legal status and destination 
for women and shows significant effects of legal status. Compared to fully regular status, mixed (RP_NWP) status is associated with a ten-percentage-point decline in the risk of becoming employed, while there is no average statistically significant difference between fully irregular and fully regular status. Additional statistical tests indicate that the difference in AMEs between fully irregular and mixed statuses is significant at $p<0.10$. While mixed status is associated with family reunification and thus inactivity during the year of arrival in Italy and Spain, most $\left(95 \%{ }^{2}\right)$ women with mixed status eventually transition into fully regular status and thus gain access to the labor market (perhaps not surprising given the EU Council Directive 2003/86/EC of 22 September $2003^{3}$ on the right to family reunification, which foresees that exclusion from the labour market is at most permitted during the first year). Reunified Senegalese women in France have this status from the start of their stay and thus face no legal barriers to eventual employment even if their economic and administrative dependence constrains their work initially. These results indicate that Senegalese women who possess or access fully regular status in the process of family reunification are likely to make an eventual transition to employment.

Irregular entry status, on the other hand, is also significantly predictive of the risk of becoming employed: having entered without a visa is associated with an increase of 9.3 percentage points in the hazard of becoming employed. Thus, women who entered without a visa are likely to become employed. While seemingly at odds with the finding that current fully regular status is associated with employment, the relationship between irregular entry and eventual employment may be indicative of interlinked regularization and employment strategies: women who enter outside of legal channels may pursue regular status as part of an employment-focused trajectory.

Variation in the effects of legal statuses for women across destinations supports the interpretation that reunified wives are likely to make a transition into employment, especially in France. Table 4.6 displays the substantial variation in the effects of legal-status categories in different destinations. Having mixed status in France is associated with a lower risk of becoming employed than having fully regular status, as is having fully irregular status. Women with fully regular status in France-who are likely to have entered through the channel of legal reunification and were the most likely to be inactive during the year of arrival-are thus the most likely to undergo a transition to employment.

The results for the southern European destinations are more complicated. Mixed status is significantly negatively related to the transition to employment in Spain while there is no association in Italy. In contrast, there is no statistically significant effect of fully irregular status in Spain, while fully irregular status in Italy is associated with an increase in the risk of employment of 20 percentage points. Senegalese women in Spain with regular status are thus the most likely to make a transition to employment, and this group is likely to be composed of both reunified spouses who gained work authorization after arrival and labor migrants with regular status- the

\footnotetext{
${ }^{2}$ Tabulation available upon request.

${ }^{3} \mathrm{http} / / /$ eur-lex.europa.eu/legal-content/EN/TXT/?uri=CELEX:32003L0086
} 
Table 4.6 Average marginal effects of legal status on risk of employment for women, by country of residence

\begin{tabular}{|c|c|c|c|c|c|c|}
\hline \multirow[b]{3}{*}{ Destination } & \multicolumn{6}{|c|}{ Legal-status variable } \\
\hline & \multicolumn{2}{|c|}{ Irregular status } & \multicolumn{2}{|c|}{ Mixed status } & \multicolumn{2}{|l|}{ No visa } \\
\hline & AME & se & AME & se & AME & se \\
\hline France & $-0.099^{+}$ & 0.058 & $-0.12 * *$ & 0.037 & $0.21 * *$ & 0.071 \\
\hline Spain & -0.13 & 0.085 & $-0.15^{*}$ & 0.077 & -0.058 & 0.048 \\
\hline Italy & $0.20 *$ & 0.10 & -0.015 & 0.052 & 0.060 & 0.042 \\
\hline
\end{tabular}

Source: MAFE-Senegal

Notes: ${ }^{+} p<0.10, * p<0.05, * * p<0.01,{ }^{* * *} p<0.001$

most likely to work upon arrival in Spain. The latter group is excluded from the model's risk set if they are already employed, meaning that the women with regular status making transitions to employment are likely to be reunified wives.

Other results may be indicative of autonomous migration strategies. The positive association between fully irregular status and transitions to employment in Italy means that migrants with fully irregular status in the first year-who are the most likely to be both in the labor force and unemployed - tend both to stay in this status and to find work. The effect of entry status is concentrated in France, where Senegalese women who enter without a visa have an employment-transition probability 21 percentage points higher than women who entered with a visa; these results may indicate an autonomous strategy where irregular entry is associated with eventual transitions to regular status and employment.

These results confirm the importance of including both entry status and timevarying legal status in models of employment for women (González-Ferrer 2011a) and suggest that women who enter through family-reunification mechanisms, who often have a mixed legal status that precludes work, are less likely to become employed than women who may circumvent such mechanisms.

Other predictors in the model are suggestive of a positive selection of employed Senegalese women: years of education, number of contacts at destination, and work experience in Senegal are all positively associated with becoming employed, suggesting that human and social capital play a role in this transition. In addition, planning to stay definitively in the destination is positively associated with becoming employed, while there is no association with having family either at destination or in Senegal.

\subsection{Discussion}

This chapter's main hypothesis is that the effect of legal status on Senegalese migrants' economic integration-as measured by first-year economic activity and employment dynamics - would vary systematically by gender as a result of gendered family reunification policies that produce different constraints and opportunities for men and women. The results for Senegalese women are largely consistent 
with a gendered migration system constructed by both legal channels open to women in the main contexts of reception and the constraints on female autonomy and mobility present in the gender norms of a patriarchal Senegalese context of exit. Across all three destination countries, women with legal-status configurations indicative of family reunification were more likely to be economically inactive during the year of arrival: women with fully regular status in France were less likely to work than women with mixed or irregular statues, while women with mixed status in Italy or Spain were less likely to work than women with fully regular statuses. These findings indicate the operation of administrative dependency (Boyd 1997; Kofman 1999; Lesselier 2008) and a concomitant decrease in the ability of women to enter the labor market. This is especially true in Spain and Italy, where legally mandated waiting periods on access to work permits erect a formal barrier to reunified spouses' participation.

Other variables associated with family reunification were also strongly predictive of first-year inactivity among women, including plans to stay definitively in the destination country, family financial participation in the trip, and having family motivations for the trip. The financial participation of women's families is overwhelmingly provided by reunifying husbands, and the association between this variable and women's inactivity suggests that men who can demonstrate the legally required financial means to bring a spouse can prevent reunified wives from working both by removing the economic necessity of women's work and potentially by making women economically dependent. Reunification and its associated economic dependency is thus a way to reproduce gendered hierarchies in a context where women's migration, even for reunification purposes, is strongly discouraged because of the fear of the loss of social control (Beauchemin et al. 2013).

Family reunification is often associated with dependency for women and at least an initial exclusion from labor-market participation, but research has also shown that reunified women may eventually work either as part of a family investment strategy (Duleep and Sanders 1993) or because of camouflaging of economic motivations in an "associational" move (Kanaiaupuni 2000). The results from this chapter support the contention that family reunification is not necessarily exclusive of eventual work. A discrete-time survival model showed that some of the legal-status configurations that were indicative of family reunification and first-year inactivity also predicted transitions into employment for women. This was directly evident for France, were women with fully regular status were more likely to make the transition to work than women with mixed or irregular status. In Spain, women with mixed status were less likely than women with regular status to make the transition; while reunified women have mixed status in Spain upon arrival, they are also able to access work authorization after a waiting period and those who do so are likely to find work. In these two countries, Kofman's (1999) observation that family reunification is liable to transform into another form of labor migration is accurate. Indeed, these findings call into question the common practice of relying on admissions categories as proxies for the motivations of individuals and also make a strong case for taking a longitudinal approach to the study of the labor-market integration of reunified migrants. 
Despite the predominance of family reunification as a legal migration channel for Senegalese women, this chapter's results also point to the existence of autonomous migration among Senegalese women with largely economic motives for their mobility. Senegalese women in France with mixed or irregular status during the year of arrival were likely not to be joining a partner and have economic motivations and were thus more likely to be employed during the year of arrival than women with fully regular status. These legal-status configurations indicate the predominance of semi-regular (in the case of students) and irregular work strategies among autonomous Senegalese women in France. In contrast, Senegalese women with fully regular status in Italy and Spain were more likely to work during the year of arrival than women with other statuses, indicating that these women are able to access legal channels of labor migration.

In contrast to the labor trajectories of Senegalese women, Senegalese men's economic integration showed little association with different configurations of legal status. Mixed status (lacking a work permit) was associated with inactivity, which is indicative of flows of students to Europe, especially France. Contrary to hypotheses, irregular status was not predictive of employment during the year of arrival, and regular status was not associated with transitions into unemployment. Senegalese men in Italy and Spain did exhibit significantly higher probabilities of employment during the year of arrival, however, lending support to the hypothesis that crossnational variation in labor markets would be associated with economic integration. It thus seems that Senegalese men are able to access employment in southern Europe regardless of their legal status, perhaps due to the extent of demand for low-skilled labor in these countries' robust informal economies, while Senegalese students in France are the only male migrants that face legal barriers to their employment.

These findings for Senegalese men are in keeping with literature that shows that migrants in such countries do not face an "ethnic penalty" in the probability of employment, but may face challenges in occupational mobility (Fullin and Reyneri 2011). Research with the MAFE data are indicative of the relatively low occupational attainment of Senegalese migrants in Europe (Obucina 2013), but additional research will be necessary to examine the link between legal status and occupational types. At the same time, Senegalese men in Spain face a higher risk of falling into unemployment than Senegalese men in France, indicating that employment, while perhaps easy to obtain, is somewhat precarious.

\subsection{Conclusion}

While the relationship between legal status and immigrant economic integration is a major concern of both policymakers and scholars, many studies of this link do not examine how the family context of migration influences both women's legal statuses and their participation in the labor market at destination. Legal status may matter more for women's economic integration because of the gendered immigration policies that produce them. While women migrants' experiences are growing 
more heterogeneous, many of them have entered destinations via the legal channel of family reunification. Their legal status is thus subject to their family situations.

Family-reunification legislation strongly structures entry channels for Senegalese women and produces legal statuses that either directly preclude their labor-market participation (as in Italy and Spain) or create other forms of economic and administrative dependency that may make them less likely to work even if they have the legal authorization to do so (as in France). Furthermore, motivations and preferences of reunified wives and their husbands also act to prevent women from working, thus acting through legal status to affect labor-market decisions of women.

This chapter found that Senegalese women with configurations of legal status indicative of family reunification were more likely than women with other legal statuses to be economically inactive upon arrival, while there is little association between Senegalese men's legal status and their participation. This finding held across destination countries despite the differing configurations of legal status granted to reunified spouses: while mixed status among women was associated with higher inactivity in Spain and Italy, so was fully regular status in France.

This is consonant with research that finds that reunified spouses tend to be less likely to be economically active (Kofman 1999). In the case of Spain and Italy these women face legal barriers to their participation as a result of waiting periods (Kofman 2004a). Women in France, however, do not face such barriers, meaning that their legal situation is also indicative of economic dependency (Lesselier 2008).

The results also show, however, that family reunification does not preclude labormarket participation, as many of the women with family-reunification profiles eventually transition into economic activity. This finding echoes the observation that family migration may transform into a form of labor migration (Kofman 1999). It also supports the view that women migrants have a diversity of motivations for their migration and may often strategically participate in an "associational" move for economic reasons (Kanaiaupuni 2000).

In contrast to Senegalese women, male migrants with fully irregular status (NRP_NWP) did not face any penalty in labor-market participation, employment, or the risk of transition to unemployment compared to migrants with fully regular status. The legal constraint of irregularity of legal status on economic activity for Senegalese migrants in Europe thus seems to be weak, supporting views that immigrants to countries with labor-market structures that favor low-skilled labor and informality reduce the immigrant "employment penalty" (Kogan 2006), perhaps at the risk of funneling them into "bad jobs" (Fullin and Reyneri 2011). 


\section{Appendix: Raw Coefficient Estimates for Models in this Chapter}

Multinomial logistic regression coefficients for first-year economic status, women and men

\begin{tabular}{|c|c|c|c|c|}
\hline \multirow[b]{3}{*}{ Predictor } & \multicolumn{2}{|l|}{ Women } & \multicolumn{2}{|l|}{ Men } \\
\hline & \multicolumn{2}{|c|}{ Outcome (ref: Unemployed) } & \multicolumn{2}{|c|}{ Outcome (ref.: Unemployed) } \\
\hline & Employed & Inactive & Employed & Inactive \\
\hline \multicolumn{5}{|c|}{ Legal status: (ref: fully regular) } \\
\hline $\begin{array}{l}\text { Fully } \\
\text { irregular (NRP_NWP) }\end{array}$ & $-0.31(-0.23)$ & $-1.73(-1.25)$ & $0.58(0.72)$ & $0.86(0.89)$ \\
\hline Mixed (RP_NWP) & $\begin{array}{l}14.03 * * * \\
(11.41)\end{array}$ & $\begin{array}{l}12.65 * * * \\
(10.48)\end{array}$ & $0.13(0.15)$ & $0.69(0.74)$ \\
\hline \multicolumn{5}{|l|}{ Destination (ref.: France) } \\
\hline Spain & $0.28(0.14)$ & $-1.92(-0.97)$ & $1.06(0.84)$ & $\begin{array}{l}-12.42 * * * \\
(-8.08)\end{array}$ \\
\hline Italy & $15.78 * * *(6.33)$ & $11.04 * * *(4.98)$ & $0.26(0.28)$ & $-4.24 *(-2.52)$ \\
\hline Fully irregular X Spain & $0.67(0.30)$ & $2.81(1.24)$ & $\begin{array}{l}-1.57 \\
(-1.12)\end{array}$ & $8.63 * * *(3.43)$ \\
\hline Fully irregulary X Italy & $\begin{array}{l}-16.88^{* * * *} \\
(-4.75)\end{array}$ & $\begin{array}{l}-12.66 * * * \\
(-3.75)\end{array}$ & $\begin{array}{l}-1.46 \\
(-1.35)\end{array}$ & $-0.63(-0.33)$ \\
\hline Mixed X Spain & $0.55(0.26)$ & $3.72^{+}(1.89)$ & $\begin{array}{l}-1.70 \\
(-0.92)\end{array}$ & $\begin{array}{l}10.05^{* * * *} \\
(3.40)\end{array}$ \\
\hline Mixed X Italy & $\begin{array}{l}-29.62 * * * \\
(-11.62)\end{array}$ & $\begin{array}{l}-24.72 * * * \\
(-10.90)\end{array}$ & $0.80(0.51)$ & $2.91(1.45)$ \\
\hline Entry status: no visa & $-2.76(-0.97)$ & $-2.48(-0.86)$ & $\begin{array}{l}-0.61 \\
(-0.82)\end{array}$ & $-0.85(-1.01)$ \\
\hline No visa $X$ Spain & $2.81(1.00)$ & $1.64(0.56)$ & $1.25(1.04)$ & $1.04(0.45)$ \\
\hline No visa $X$ Italy & $2.91(1.09)$ & $3.45(1.26)$ & $0.34(0.37)$ & $2.29(1.45)$ \\
\hline $\begin{array}{l}\text { Period of arrival: } \\
\text { post-1990 }\end{array}$ & $0.13(0.07)$ & $-0.07(-0.04)$ & $\begin{array}{l}-0.03 \\
(-0.05)\end{array}$ & $-0.58(-0.79)$ \\
\hline Age at start of current trip & $0.04(0.55)$ & $0.03(0.36)$ & $\begin{array}{l}-0.01 \\
(-0.17)\end{array}$ & $0.03(0.41)$ \\
\hline Years of education & $-0.08(-0.65)$ & $-0.07(-0.60)$ & $\begin{array}{l}-0.03 \\
(-0.76)\end{array}$ & $0.21 *(2.36)$ \\
\hline Ethnicity: Wolof & $0.91(0.85)$ & $1.10(1.02)$ & $0.74^{+}(1.87)$ & $0.48(0.86)$ \\
\hline Religion: Mouride & $0.58(0.55)$ & $0.50(0.47)$ & $0.50(1.12)$ & $0.19(0.32)$ \\
\hline $\begin{array}{l}\text { Number of contacts at } \\
\text { destination }\end{array}$ & $0.32^{+}(1.95)$ & $0.40 *(2.28)$ & $\begin{array}{l}-0.04 \\
(-0.38)\end{array}$ & $0.03(0.24)$ \\
\hline Number of trips & $2.37^{+}(1.88)$ & $2.70 *(2.12)$ & $0.07(0.45)$ & $-0.27(-0.67)$ \\
\hline $\begin{array}{l}\text { Does not speak lang. of } \\
\text { destination }\end{array}$ & $-1.48^{+}(-1.76)$ & $-0.90(-1.00)$ & $\begin{array}{l}-0.25 \\
(-0.53)\end{array}$ & $-0.15(-0.14)$ \\
\hline $\begin{array}{l}\text { Self-reported econ. status: } \\
\text { good }\end{array}$ & $2.93(1.53)$ & $1.93(0.98)$ & $\begin{array}{l}-0.07 \\
(-0.08)\end{array}$ & $0.42(0.43)$ \\
\hline Spouse or kid at dest. & $-0.41(-0.54)$ & $-0.34(-0.43)$ & $1.50^{+}(1.90)$ & $-0.71(-0.68)$ \\
\hline
\end{tabular}




\begin{tabular}{|c|c|c|c|c|}
\hline \multirow[b]{3}{*}{ Predictor } & \multicolumn{2}{|l|}{ Women } & \multicolumn{2}{|l|}{ Men } \\
\hline & \multicolumn{2}{|c|}{ Outcome (ref: Unemployed) } & \multicolumn{2}{|c|}{ Outcome (ref.: Unemployed) } \\
\hline & Employed & Inactive & Employed & Inactive \\
\hline Spouse or kid in Sn & $0.08(0.10)$ & $-1.26(-1.55)$ & $\begin{array}{l}-0.38 \\
(-0.91)\end{array}$ & $-0.43(-0.65)$ \\
\hline $\begin{array}{l}\text { Geographic origin: from } \\
\text { Dakar }\end{array}$ & $\begin{array}{l}-2.36^{* *} \\
(-2.64)\end{array}$ & $-2.32 *(-2.53)$ & \begin{tabular}{|l|}
-0.07 \\
$(-0.17)$
\end{tabular} & $1.15^{+}(1.76)$ \\
\hline $\begin{array}{l}\text { Father's ed.: < secondary } \\
\text { school }\end{array}$ & $1.27(1.18)$ & $1.00(0.94)$ & $0.07(0.15)$ & $-0.12(-0.22)$ \\
\hline Trip paid by family & $-0.08(-0.11)$ & $0.60(0.85)$ & \begin{tabular}{|l|}
-0.46 \\
$(-1.05)$
\end{tabular} & $\begin{array}{l}-2.15^{* *} \\
(-3.22) \\
\end{array}$ \\
\hline Plan to stay: definitive & $-2.04 *(-1.98)$ & $-1.06(-0.99)$ & $0.17(0.41)$ & $0.45(0.80)$ \\
\hline $\begin{array}{l}\text { Motivation for migration: } \\
\text { work }\end{array}$ & $0.58(0.80)$ & $-0.83(-1.09)$ & \begin{tabular}{|l|}
-0.05 \\
$(-0.10)$
\end{tabular} & $-1.44 *(-2.22)$ \\
\hline $\begin{array}{l}\text { At least one parent alive in } \\
\text { Senegal }\end{array}$ & $\begin{array}{l}-16.97 * * * \\
(-9.88)\end{array}$ & $\begin{array}{l}-16.12 * * * \\
(-8.94)\end{array}$ & $\begin{array}{l}-1.93^{+} \\
(-1.67)\end{array}$ & $-1.87(-1.19)$ \\
\hline Employed before trip & $2.35 *(2.11)$ & $2.81 *(2.42)$ & $0.74(1.29)$ & $0.58(0.59)$ \\
\hline Inactive before trip & $1.44(1.02)$ & $3.90 * *(2.72)$ & $1.14(1.20)$ & $3.62 * *(2.82)$ \\
\hline Years of work exp. (Sn) & $-0.12(-1.43)$ & $-0.13(-1.50)$ & $0.03(1.18)$ & $-0.04(-1.00)$ \\
\hline Constant & $16.81 * * *(6.26)$ & $15.44 * * *(5.50)$ & $3.19(1.57)$ & $-0.13(-0.05)$ \\
\hline Observations & \multicolumn{2}{|l|}{309} & \multicolumn{2}{|l|}{454} \\
\hline Pseudo R-squared & \multicolumn{2}{|l|}{0.417} & \multicolumn{2}{|l|}{0.455} \\
\hline $\mathrm{AIC}$ & \multicolumn{2}{|l|}{413.86} & \multicolumn{2}{|l|}{475.27} \\
\hline $\mathrm{BIC}$ & \multicolumn{2}{|l|}{607.99} & \multicolumn{2}{|l|}{738.83} \\
\hline Log likelihood & \multicolumn{2}{|l|}{-154.93} & \multicolumn{2}{|l|}{-173.64} \\
\hline Degrees of freedom & \multicolumn{2}{|l|}{45} & \multicolumn{2}{|l|}{62} \\
\hline
\end{tabular}

Source: MAFE-Senegal

Notes: $\mathrm{t}$ statistics in parentheses. ${ }^{+} p<0.10,{ }^{*} p<0.05,{ }^{* *} p<0.01,{ }^{* * *} p<0.001$. Multinomial logistic regression coefficients. Clustered standard errors

Discrete-time survival model for transitions into and out of employment for men and women, logistic regression coefficients

\begin{tabular}{l|l|l}
\hline \multirow{2}{*}{ Predictor } & Outcome & \\
\cline { 2 - 3 } & Women & Men \\
\cline { 2 - 3 } & Employment & Unemployment \\
\hline Legal status (ref.: fully regular) & \multicolumn{2}{l}{} \\
\hline Fully irregular (NRP_NWP) & $-1.17(-1.24)$ & $-0.32(-0.23)$ \\
\hline Mixed (RP_NWP) & $-1.47^{*}(-2.16)$ & $-1.53(-1.02)$ \\
\hline Destination (ref.: France) & $0.79(1.05)$ & $1.91(1.39)$ \\
\hline Spain & $-2.04(-1.43)$ & $1.25(0.87)$ \\
\hline Italy & $-0.23(-0.17)$ & $0.96(0.56)$ \\
\hline Fully irregular X Spain & $3.40 *(2.05)$ & $-2.32(-1.28)$ \\
\hline Fully irregular X Italy & $-0.44(-0.42)$ & $0.00()$. \\
\hline Mixed X Spain & $1.04(0.70)$ & $2.15(1.23)$ \\
\hline Mixed X Italy & &
\end{tabular}




\begin{tabular}{|c|c|c|}
\hline \multirow[b]{3}{*}{ Predictor } & \multicolumn{2}{|l|}{ Outcome } \\
\hline & Women & Men \\
\hline & Employment & Unemployment \\
\hline Entry status: no visa & $1.61 * *(3.27)$ & $-0.79(-1.02)$ \\
\hline No visa $X$ Spain & $-2.62 *(-2.42)$ & $2.23^{+}(1.89)$ \\
\hline No visa $X$ Italy & $-0.34(-0.34)$ & $0.65(0.62)$ \\
\hline Years in dest. & $0.14(1.01)$ & $-0.99(-1.18)$ \\
\hline Years in dest. squared & $-0.01 *(-2.47)$ & $-0.00(-0.73)$ \\
\hline Duration at risk & $0.10(0.80)$ & $0.06(0.18)$ \\
\hline Period of arrival: post-1990 & $1.50 * * *(3.33)$ & $1.20^{+}(1.84)$ \\
\hline Number of act. spells & $0.83 * * *(4.27)$ & $2.85 * * *(6.22)$ \\
\hline Age at start of current migration spell & $-0.02(-0.79)$ & $-0.08(-1.50)$ \\
\hline Years of education & $0.09 * *(2.61)$ & $-0.03(-0.43)$ \\
\hline Ethnicity: Wolof & $-0.46(-1.58)$ & $0.43(0.52)$ \\
\hline Religion: Mouride & $-0.36(-0.58)$ & $-1.02(-1.28)$ \\
\hline Years of ed. in dest. & $-0.05(-0.50)$ & $0.91(1.03)$ \\
\hline Self-reported econ. status: good & $-0.25(-0.33)$ & \\
\hline Number of contacts at destination & $0.12 *(2.03)$ & $-0.25^{+}(-1.83)$ \\
\hline Number of trips & $0.55(1.57)$ & $-0.02(-0.17)$ \\
\hline Does not speak language of destination & $-0.10(-0.17)$ & $-0.88(-1.29)$ \\
\hline Work exp. at dest. & - & $1.13(1.12)$ \\
\hline Unemployed & Ref. & - \\
\hline Employed & - & Ref. \\
\hline Inactive & $-0.96^{+}(-1.66)$ & $-0.40(-0.35)$ \\
\hline Manual occupation & - & $0.39(0.66)$ \\
\hline ISEI & - & $0.04 *(2.07)$ \\
\hline Spouse or kid at dest. & $0.08(0.17)$ & $0.25(0.50)$ \\
\hline Spouse or kid in Sn & $0.44(0.93)$ & $-0.61(-1.01)$ \\
\hline Geographic origin: from Dakar & $0.29(0.76)$ & $-0.11(-0.19)$ \\
\hline Father's ed.: < secondary school & $0.12(0.35)$ & $-0.57(-1.23)$ \\
\hline Trip paid by family & $0.02(0.04)$ & $-1.72 *(-2.58)$ \\
\hline Plan to stay: definitive & $0.71^{+}(1.86)$ & $0.46(0.88)$ \\
\hline Motive: work/better life & $0.53(1.44)$ & $-0.68(-1.33)$ \\
\hline Work exp. in Sn (years) & $0.07 * *(3.09)$ & \\
\hline Constant & $-6.89 * * *(-4.98)$ & $-8.86 * *(-3.28)$ \\
\hline Observations & 819 & 4010 \\
\hline Pseudo R-squared & 0.232 & 0.362 \\
\hline AIC & 502.15 & 332.42 \\
\hline $\mathrm{BIC}$ & 666.93 & 552.80 \\
\hline Log likelihood & -216.08 & -131.21 \\
\hline$\chi^{2}$ & 130.91 & 699.25 \\
\hline Degrees of freedom & 34 & 34 \\
\hline
\end{tabular}

Source: MAFE-Senegal

Notes: t statistics in parentheses. ${ }^{+} p<0.10,{ }^{*} p<0.05$, ${ }^{*} p<0.01$, ${ }^{* * *} p<0.001$. Logistic regression coefficients displayed. Clustered standard errors 


\section{References}

Amuedo-Dorantes, C., Malo, M. A., \& Muñoz-Bullón, F. (2013). New evidence on the impact of legal status on immigrant labor market performance: The Spanish case. LABOUR, 27(1), 93-113.

Baizan, P., Beauchemin, C., \& Ferrer, A. G. (2011). A reassessment of family reunification in Europe: The case of Senegalese couples (Vol. 16). Paris: INED.

Barou, J. (1993). Les immigrations Africaines En France: Des «navigateurs» Au «regroupement Familial». Revue Française Des Affaires Sociales, 1, 193-205.

Beauchemin, C., Caarls, K., \& Mazzucato, V. (2013). Senegalese migrants between here and there: An overview of family patterns. MAFE Working Papers (MAFE Working Paper 33). Paris: INED.

Bernardi, F., Garrido, L., \& Miyar, M. (2011). The recent fast upsurge of immigrants in Spain and their employment patterns and occupational attainment. International Migration, 49(1), 148-187.

Borjas, G. J. (1985). Assimilation, changes in Cohort quality, and the earnings of immigrants. Journal of Labor Economics, 3(4), 463-489.

Borjas, G. J. (1995). Assimilation and changes in Cohort quality revisited: What happened to immigrant earnings in the 1980s? Journal of Labor Economics, 13(2), 201-245.

Boyd, M. (1989). Family and personal networks in international migration: Recent developments and new agendas. International Migration Review, 23(3), 638-670.

Boyd, M. (1997). Migration policy, female dependency, and family membership: Canada and Germany. In P. M. Evans \& G. R. Wekerle (Eds.), Women and the Canadian welfare state: Challenges and change (pp. 142-169). Toronto: University of Toronto Press.

Bradatan, C. E., \& Sandu, D. (2012). Before crisis: Gender and economic outcomes of the two largest immigrant communities in Spain. International Migration Review, 46(1), 221-243.

Castagnone, E., Sakho, P., Nazio, T., Schoumaker, B., \& Rakotonarivo, N. (2013). African migrants at work. Patterns of labour market integration in Europe, transnational economic participation and economic re-integration of migrants in origin countries. The case of Senegal. MAFE working papers (MAFE Working Paper 29). Paris: INED.

Cerrutti, M., \& Massey, D. S. (2001). On the auspices of female migration from Mexico to the United States. Demography, 38(2), 187-200.

Chiswick, B. R. (1978). The effect of Americanization on the earnings of foreign-born men. Journal of Political Economy, 86(5), 897-921.

Chort, I., Gubert, F., \& Senne, J.-N. (2012). Migrant networks as a basis for social control: Remittance incentives among Senegalese in France and Italy. Regional Science and Urban Economics, 42(5), 858-874.

Constant, A., \& Zimmermann, K. F. (2005). Immigrant performance and selective immigration policy: A European perspective. National Institute Economic Review, 194(1), 94-105.

di Friedberg, O. S. (1993). L'immigration Africaine En Italie: Le Cas Sénégalais. Etudes Internationales, 24(1), 125-140.

Donato, K. M., \& Massey, D. S. (1993). Effect of the immigration reform and control act on the wages of Mexican migrants. Social Science Quarterly (University of Texas Press), 74(3), 523-541.

Donato, K. M., Wakabayashi, C., Hakimzadeh, S., \& Armenta, A. (2008). Shifts in the employment conditions of Mexican migrant men and women The effect of U.S. immigration policy. Work and Occupations, 35(4), 462-495.

Duleep, H. O., \& Sanders, S. (1993). The decision to work by married immigrant women. Industrial and Labor Relations Review, 46(4), 677-690.

Fullin, G., \& Reyneri, E. (2011). Low unemployment and bad jobs for new immigrants in Italy. International Migration, 49(1), 118-147.

González-Enríquez, C. (2009). Spain, the cheap model: Irregularity and regularisation as immigration management policies. European Journal of Migration and Law, 11, 139. 
González Ferrer, A. (2006). Family and labor strategies in migration: Family reunification, marital choices and labor participation of immigrants in the Host country. Doctoral thesis, Instituto Juan March de Estudios e Investigaciones, Centro de Estudios Avanzados en Ciencias Sociales, Universidad Autónoma de Madrid, Madrid.

González-Ferrer, A. (2011a). Explaining the labour performance of immigrant women in Spain: The interplay between family, migration and legal trajectories. International Journal of Comparative Sociology, 52(1-2), 63-78.

González-Ferrer, A. (2011b). The reunification of the spouse among recent immigrants in Spain. Links with undocumented migration and the labour market. In A. Kraler, E. Kofman, M. Kohli, \& C. Schmoll (Eds.), Gender, Generations and the family in international migration (pp. 143166). Amsterdam: Amsterdam University Press.

Hall, M., Greenman, E., \& Farkas, G. (2010). Legal status and wage disparities for Mexican immigrants. Social Forces, 89(2), 491-513.

Heath, A., \& Ridge, J. (1983). Social mobility of ethnic minorities. Journal of Biosocial Science, 15.(Supplement S8, 169-184.

Huddleston, T., Dag Tjaden, J., \& Callier, L. (2012). Immigrant citizens survey: How immigrants experience integration in 15 European cities. Brussels: King Baudouin Foundation and Migration Policy Group.

Kaag, M. (2008). Mouride transnational livelihoods at the margins of a European society: The case of residence Prealpino, Brescia, Italy. Journal of Ethnic \& Migration Studies, 34(2), 271-285.

Kanaiaupuni, S. M. (2000). Reframing the migration question: An analysis of men, women, and gender in Mexico. Social Forces, 78(4), 1311-1347.

Kofman, E. (1999). Female 'birds of passage' a decade later: Gender and immigration in the European union. International Migration Review, 33(2), 269-299.

Kofman, E. (2004a). Family-related migration: A critial review of European studies. Journal of Ethnic and Migration Studies, 30(2), 243-262.

Kofman, E. (2004b). Gendered global migrations. International Feminist Journal of Politics, 6(4), 643-665.

Kogan, I. (2006). Labor markets and economic incorporation among recent immigrants in Europe. Social Forces, 85(2), 697-721.

Kossoudji, S. A., \& Cobb-Clark, D. A. (2000). IRCA's impact on the occupational concentration and mobility of newly-legalized Mexican men. Journal of Population Economics, 13(1), 81-98.

Kossoudji, S. A., \& Cobb-Clark, D. A. (2002). Coming out of the shadows: Learning about legal status and wages from the legalized population. Journal of Labor Economics, 20(3), 598-628.

Lesselier, C. (2008). Politiques d'immigration en France : appréhender la dimension de genre. Les cahiers du CEDREF. Centre d'enseignement, d'études et de recherches pour les études féministes, 16, 189-208.

Mahler, S. J., \& Pessar, P. R. (2006). Gender matters: Ethnographers bring gender from the periphery toward the core of migration studies. International Migration Review, 40(1), $27-63$.

Massey, D. S. (1987). Do undocumented migrants earn lower wages than legal immigrants? New evidence from Mexico. International Migration Review, 21(2), 236-274.

Massey, D. S., Durand, J., \& Malone, N. J. (2002). Beyond smoke and mirrors: Mexican immigration in an era of economic integration. New York: Russell Sage Foundation.

Mezger, C., \& González-Ferrer, A. (2013). The impol database: A new tool to measure immigration policies in France, Italy and Spain since the 1960s (Vol. 34). Paris: INED.

Mincer, J. (1978). Family migration decisions. Journal of Political Economy, 86(5), 749-773.

Obucina, O. (2013). Occupational trajectories and occupational cost among Senegalese immigrants in Europe. Demographic Research, 28, 547-580.

Pascual de Sans, Angels, J. C., \& Solana, M. S. (2000). Recent immigration to catalonia: Economic character and responses. In R. King, G. Lazaridis, \& C. Tsardanidis (Eds.), Eldorado or fortress?: Migration in Southern Europe (pp. 104-124). New York: St. Martin's Press. 
Phillips, J. A., \& Massey, D. S. (1999). The new labor market: Immigrants and wages after IRCA. Demography, 36(2), 233-246.

Piore, M. J. (1979). Birds of passage: Migrant labor and industrial societies. Cambridge: Cambridge University Press.

Portes, A. (1978). Introduction: Toward a structural analysis of illegal (undocumented) immigration. International Migration Review, 12(4), 469-484.

Raghuram, P. (2004). The difference that skills make: Gender, family migration strategies and regulated labour markets. Journal of Ethnic and Migration Studies, 30(2), 303-321.

Reyneri, E., \& Fullin, G. (2011). Labour market penalties of new immigrants in new and old receiving west European countries. International Migration, 49(1), 31-57.

Riccio, B. (2001). From 'ethnic group' to 'transnational community'? Senegalese migrants' ambivalent experiences and multiple trajectories. Journal of Ethnic and Migration Studies, 27, 583-599.

Riccio, B. (2008). West African transnationalisms compared: Ghanaians and Senegalese in Italy. Journal of Ethnic \& Migration Studies, 34(2), 217-234.

Rivera-Batiz, F. L. (1999). Undocumented workers in the labor market: An analysis of the earnings of legal and illegal Mexican immigrants in the United States. Journal of Population Economics, 12(1), 91-116.

Sandell, S. H. (1977). Women and the economics of family migration. The Review of Economics and Statistics, 59(4), 406-414.

Tall, S. M. (2008b). Les Émigrés Sénégalais En Italie. Transferts Financiers et Potentiel de Développement de l'habitat Au Sénégal. In M.-C. Diop (Ed.), Le Sénégal Des Migrations: Mobilités, Identités Et Sociétés, Hommes et sociétés (pp. 37-67). Paris: Karthala.

Timera, M. (1997). L'immigration Africaine En France: Regards Des Autres et Repli Sur Soi: La France et Les Migrants Africains= The African immigration in France: The withdrawal of the other: France and the African migrants. Politique Africaine, 67, 41-47.

Toma, S. (2012). Ties that bind? Networks and gender in international migration. D.Phil. thesis, Nuffield College, University of Oxford, Oxford.

Open Access This chapter is licensed under the terms of the Creative Commons Attribution 4.0 International License (http://creativecommons.org/licenses/by/4.0/), which permits use, sharing, adaptation, distribution and reproduction in any medium or format, as long as you give appropriate credit to the original author(s) and the source, provide a link to the Creative Commons licence and indicate if changes were made.

The images or other third party material in this chapter are included in the chapter's Creative Commons licence, unless indicated otherwise in a credit line to the material. If material is not included in the chapter's Creative Commons licence and your intended use is not permitted by statutory regulation or exceeds the permitted use, you will need to obtain permission directly from the copyright holder.

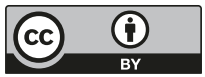




\section{Chapter 5 \\ Legal Status, Territorial Confinement, and Transnational Activities of Senegalese Migrants in France, Italy, and Spain}

Migrants have long maintained ongoing social, economic, and political connections with their homelands, but these transnational activities have garnered increased attention from scholars and policymakers in recent years. Academic research has shown that modern travel and communications technologies have created new kinds and quantities of transnational engagement, findings which have challenged the notions of the state control of borders and of unidirectional immigrant settlement and assimilation. At the same time, international development agencies and sending-country governments have begun to recognize the potential of migrants to be active participants in the development of their home communities. Such "co-development" strategies seek to leverage migrant cross-border activities, such as remittances, investment, and participation in hometown associations, as part of overall development strategies.

Such celebrations of immigrant transnationalism ignore the constraint that irregular legal status may place on cross-border engagement. While much research on transnationalism argues that these activities transgress and subvert the state's ability to control cross-border flows, scholars have generally not been attentive to the sensitivity of different kinds of cross-border action to robust immigration-control apparatuses. Transnational activities that are mobile-such as visits to the homeland-may be more directly structured by legal-status constraints than non-mobile activities such as remitting. Furthermore, studies recognize occasional physical visits to the homeland to be an important component of the transnational social field, both as an important link between destination and origin in its own right and as a crucial way to maintain the affective links that sustain non-mobile activities such as remitting and investing. Yet most research does not consider the direct constraint on

\footnotetext{
The original version of this chapter was revised: Footnote was inserted in the chapter opening page. The correction to this chapter is available at https://doi.org/10.1007/978-3-030-12088-7_7

Portions of Chapter 5 were previously published as: Vickstrom, E. R., \& Beauchemin, C. (2016). Irregular status, territorial confinement, and blocked transnationalism: Legal constraints on circulation and remittances of Senegalese migrants in France, Italy, and Spain. Comparative Migration Studies, 4(1), 1-29. https://doi.org/10.1186/s40878-016-0037-8.
} 
physical mobility faced by migrants without secure legal status or the effect that such reduction in mobility might have for non-mobile, long-distance activities. Nor do policy prescriptions for co-development, which actively promote migrant crossborder engagement, factor in the contradictory state policies that lead to the legal confinement and subsequent reduced transnational participation of migrants.

This chapter explores the link between legal status and transnational activities through the lenses of territorial confinement and blocked transnationalism. It hypothesizes that irregular legal status results both in direct territorial confinement-an inability to visit the homeland - and in indirect caging of non-mobile transnational activities. This caging is hypothesized to result from the withering of affective ties associated with reduced physical co-presence with kin and other important individuals in the homeland from which migrants often draw their sense of status. The chapter also explores the constraint of irregular status on non-mobile transnational activities through structural exclusion from institutions in the destination country.

Senegalese migrants in France, Italy, and Spain provide the empirical data on which these hypotheses are tested. Senegalese migrants are renowned in the qualitative literature for practicing "transnational livelihoods" predicated on circulation between the destination and the homeland and the accumulation of material wealth and social status in Senegal in preparation for an eventual return. At the same time, Senegalese migrants often lack secure legal status: those without "papers" are often "stuck" in the destination country and may thus face challenges in constructing a transnational existence. Thus the development potential of this group of migrantslauded by the French and Spanish government and coveted by the Senegalese state - may be short circuited by lack of secure legal status.

The chapter is organized as follows. The next section reviews the literature on transnational activities and suggests that scholars of transnationalism have largely overlooked both the physical confinement resulting from irregular status and the indirect effect of this confinement on non-mobile activities. The chapter then presents some qualitative evidence on the transnational participation of Senegalese migrants. The following section describes the data and methods for the empirical analysis. The results confirm that irregular status is negatively associated with short visits to the homeland, resulting in a territorial confinement that is transmitted to the non-mobile activities of remitting and investing. Discussion of the findings follow and a final section concludes.

\subsection{Types of Transnational Activities}

Since the early 1990s, the concepts of migrant transnational activities-social, economic, cultural, and political actions that migrants living abroad carry out in their home country - and migrant transnationalism - the condition of being that accompanies such cross-border action - have ridden a theoretical and empirical rollercoaster in the social sciences. Researchers initially hailed the concepts as a novel lens for understanding the lived bifocal realities of migrants in advanced postindustrial economies, with advances in transportation and communications technologies making it possible 
for these migrants to live their lives simultaneously in destination and sending countries (Glick Schiller et al. 1995; Portes et al. 1999). Subsequent research has sought to distinguish migrant from other types of transnationalism but also questioned the novelty, normativity, scope, and liberatory potential of the phenomenon (Foner 1997; Waldinger and Fitzgerald 2004). The current consensus is that, while transnational activities are neither novel nor practiced by all immigrants everywhere, the concept still serves as an important conceptual lens for understanding a distinct path of immigrant incorporation (Portes 2010): immigrants are no longer limited by the social, cultural, economic, and political opportunities offered to them by their new host societies but can draw on cross-border ties to conduct their lives transnationally.

With the recognition that transnational engagement is neither widespread nor normative has come an insistence on the heterogeneity of transnational practices. Migrants' activities linking receiving and sending areas can take on a variety of forms, and researchers have commonly arranged them according to the typology of economic, political, and sociocultural transnational activities (Boccagni 2012b; Itzigsohn and Saucedo 2002; Portes et al. 1999). Economic transnational activities include sending monetary and in-kind remittances, investments in property or businesses in the homeland, circular labor migration, and informal cross-border trading enterprises. Political transnational activities include distance voting, the exercise of dual citizenship, fundraising or other support in the destination for candidates in the homeland, and even running for and holding office in the homeland while residing abroad. Sociocultural transnational activities can include visits or "systematic communication at a distance" with family members and friends in the homeland, organization of homeland-oriented cultural activities abroad, and participation in civic, recreational, or solidarity initiatives. Some scholars also classify participating in hometown associations (HTAs) as a political activity given the influence they can have on local power dynamics in the hometown (Portes et al. 1999). Research has thus shown that a wide variety of kinds of activities make up the transnational social space.

\subsection{The Role of the State in Migrant Transnational Activities}

Following Portes et al.'s (1999) call to delimit the phenomenon of transnationalism empirically, the last decade has seen a flowering of studies of a myriad of kinds of transnational activities among a wide variety of groups (for a review, see Levitt and Jaworsky 2007). Research has also focused on the determinants of cross-border social action. Many studies have shown that individual characteristics such as age, education, occupation, and length of residence in the host community are associated with a variety of transnational activities, and scholars have concluded that engaging in sustained interaction with the homeland is not a threat to migrants' successful integration in the destination society (Guarnizo 2003; Guarnizo et al. 2003; Itzigsohn and Saucedo 2002).

What has been missing from this literature, however, is an examination of how state immigration-control apparatuses and the legal statuses they produce (see Chap. 2) may also structure transnational activities. Given the widespread acknowledgement 
of the preponderant role that legal status plays in the incorporation of migrants in the destination society (Massey 2007; Portes and Rumbaut 2006), it is surprising that scholars have paid so little attention to the impact that legal status may have on the transnational activities that have been shown to accompany such integration.

This oversight may be due, in part, to a tension in the transnational-studies literature regarding the conceptualization of the role of the state. Much of the early literature on migrant transnational activities focused on the subversive character of these activities vis-à-vis national borders. Transnational activities explicitly take place across borders and seemingly despite state attempts at control, and some scholars found the very fact of subverting a border to be a sign of the weakness or even inability of the state to control flows of people, money, ideas, and values (Glick Schiller et al. 1995).

In this view, the state and its territorial border-and the national membership that this frontier implies-are unable to contain the globe-spanning networks that "transmigrants" construct via their incessant physical, social, and economic connections to the homeland. These connections, it is argued, are possible mainly because of technological advances in travel and communications that compress time and space: jumbo jets make formerly insurmountable distances between destination and origin easily traveled, and mobile phones and the internet allow migrants to be in daily touch with their families in the homeland (Vertovec 2003). While subsequent historical work has questioned the argument that cross-border engagement is a novel form of social action (Foner 1997), new technologies have made these activities easier and cheaper, and have thus had an impact on the quantity and kinds of cross-border engagement (Portes et al. 2002).

Despite the assertion that technologically advanced migration transnational activities indicate a diminished ability of national borders to contain migrant transnational activities, there are reasons to be skeptical of pronouncements of the demise of the state. While technology and its democratization are certainly necessary conditions for current transnational activities (Portes et al. 1999), the same technology that facilitates the flows of people, money, and ideas in the current globalized world has also undoubtedly led to increased state immigration-control capacities. As Zolberg's work demonstrates for the US, migration-control apparatuses have long kept pace with advances in technology: the American government introduced a system of "remote control" of immigration in the nineteenth century through its requirement of passports and visas and concomitant network of overseas consulates, and was successfully able to screen out potential immigrants that it deemed "undesirable" (Zolberg 1999). The role of technology is well documented in contemporary border control: the governments of the US and Europe have spent massive sums of money to increase surveillance along their southern borders (Carling 2007; Massey et al. 2002). Governments have also introduced biometric visas and identity documents and electronic document verification systems for immigrant workers. The technology that has created the conditions for transnational activities has thus also created the possibility of increased control of those flows.

Research has also shown, however, that the technological ability to control migration flows is a necessary but not sufficient condition for such control, as it 
must be coupled with political will to instill and enforce such systems. Formal systems of immigration control are often compromised by special interests, allowing unauthorized flows to continue through "back doors" for reasons of political and economic expediency (Freeman 1995; Zolberg 1999). State immigration-control capacity is thus often variable, contested, and contingent on a variety of economic and political factors. The existence of transnational flows does not necessarily call into question the ability of the state to contain such flows.

Indeed, recent research has argued that the state needs to be "brought back in" to the study of transnational activities. Waldinger (2008) argues that international migrants have and will always participate in the kind of cross-border activities celebrated as transnational; what is missing in the analysis, he argues, is analysis of the ability of the state and its borders to bound both identificational and territorial belonging. States and their efforts to control borders can act to "cage" migrants, both through processes of settlement and territorial confinement. The identificational demands of modern nation-states encourage legally resident migrants with an initially transnational orientation to abandon it in favor of identification with the destination polity.

For those migrants not legally part of the national group, state efforts to control movement across borders effectively confine them to the territory of the destination country; this constraint on physical mobility entails the progressive withering of the social ties that nourish cross-border engagement (Waldinger 2008). Waldinger (2008) describes this process as "double capture" in which the destination state constrains the cross-border engagement of both documented and undocumented migrants. Thus, the state not only has an impact on transnational activities in ways that run counter to the subversive description of migrant transnationalism, but its efforts to police its borders and ensure social closure are of primary importance for the ability of migrants to engage in these activities. Indeed, scholars have begun calling for approaches to transnationalism that grapple with the political and legal constraints on mobility (Boccagni 2012b; Mountz et al. 2002).

\subsection{Homeland Visits and Territorial Confinement of Migrants with Irregular Status}

How does the legal reality of the state, its borders, and the concomitant legal statuses constrain the cross-border actions of migrants? The answer to that question depends, in part, on the action under consideration. Some transnational activities may be more sensitive to legal reality than others, especially those that depend in some way on migrants having a secure legal status in the destination society. The most relevant example is travel between destination and origin. While this kind of travel is certainly much easier, cheaper, and quicker in the contemporary world than before, destination states are also more technologically capable of restricting movements across their borders. As Waldinger (2008) points out, migrants do not come 
and go as they please, but only engage in physical cross-border mobility to the extent that states allow it.

Legal status is clearly the key factor in allowing migrants to travel freely between destination and their home communities: those migrants who lack secure legal status are less likely to engage in this kind of circulation because they are not guaranteed re-entry and do not want to risk the cost and potential danger of an unauthorized entry (Massey et al. 2002).Empirical research bears out the relationship between legal status and circulation. Kaag (2008) finds that Senegalese migrants in Italy without "papers" describe themselves as being "stuck" because they do not want to expose themselves to the cost and risk of an additional irregular passage. Waldinger (2008) finds that homeland visits are the most common form of cross-border activity among his sample of Colombians, Cubans, Dominicans, and Salvadorans, but he also finds that secure legal status strongly predicts the probability of travel home. Immigration policies and politics are thus a crucial conditioning factor for this form of cross-border engagement: migrants who lack secure legal status experience a "territorial confinement" (Waldinger 2008) that constrains their movement across the national border. We would thus expect a direct negative effect of irregular legal status on Senegalese migrants' propensity to return home for short visits because of the political barrier to mobility inherent in irregular status.

\subsection{Blocked Transnationalism and Structural Exclusion}

While the constraint that legal reality places on physical circulation between destination and origin is unambiguous, the link between legal status and cross-border action is less clear for other transnational activities. Why would irregular legal status constrain remittances, investments, or participation in associations? The literature provides some answers in the form of the concepts of blocked transnationalism and structural exclusion. Restrictive immigration-control policies are a negative feature of the context of reception that can block transnational ties with the home country (Portes and Rumbaut 2006). This blocked transnationalism manifests itself in the structural exclusion of migrants with irregular status from various formal institutions in the destination society (Bloch 2008; Mazzucato 2008; Van Meeteren 2012).

Lack of legal status can, for example, prevent migrants from participating in the formal labor market, relegating them to informal, precarious, and low-paid jobs; this insecurity could make them less likely to have the means to participate in transnational activities. Lack of legal status could also constrain participation in various financial institutions: not having a bank account or not being able to access credit could reduce migrants' abilities to send remittances to and invest in assets in Senegal, for example. Structural exclusion could thus be considered an indirect effect of irregular legal status: the direct constraint of insecure legal status is on migrants' ability to participate in formal institutions, which in turn limits migrants' transnational engagement; lacking data on this kind of participation, then, legal 
status can act as a proxy for this kind of structural exclusion. We would thus expect a direct negative effect of irregular legal statuses on remitting, investing, and participating in HTAs because of blocked transnationalism and the structural exclusion it engenders.

\subsection{Affective Ties, Homeland Visits, and Non-mobile Transnational Activities}

The negative effect of territorial confinement on circulation between destination and origin coupled with research that strongly demonstrate the importance of affective ties and physical co-presence for ongoing transnational engagement together suggest a negative indirect effect of irregular status on long-distance, non-mobile transnational activities functioning through the withering of social ties. The territorial confinement and structural exclusion hypotheses both posit a negative effect of irregular legal statuses on Senegalese migrants' cross-border activities: irregular status simultaneously constrains migrants' abilities to cross the destination state's borders and to participate in formal institutions that promote other forms of crossborder engagement. The constraint that the legal reality imposes thus depends on the kind of activity and whether that activity involves the physical crossing of a border. The literature suggests, however, that occasional physical border-crossing itself may be vitally related to the ability of migrants to maintain the social ties that underlie continued long-distance transnational activities. If lack of secure legal status constrains visits to the homeland, this constraint could be transmitted to longdistance, non-mobile activities by the weakening of social ties.

What is it about visits home that might encourage other kinds of transnational engagement? Studies of transnationalism often assert that advances in communications technologies have rendered physical distance, and the need for physical copresence, obsolete (Diminescu 2008). Virtual co-presence, in this view, substitutes effectively for physical co-presence in nourishing the social links that motivate and sustain regular cross-border social engagement. While scholars of mobility have recognized the potential for communications technologies to compress space and time in novel ways, there is still some doubt as to the ability of virtual communication to replace physical face-to-face interactions (Boccagni 2012a).

Mobility research has found, for example, that interactions involving physical co-presence are necessary for developing extended relations of trust (Urry 2002). Indeed, even communications at a distance, while allowing some maintenance of social ties, actually increase the need to reinvigorate these relationships via occasional physical co-presence (Boccagni 2012a; Urry 2002). Physical visits to the homeland allow migrants to build and renew the trust and emotional identification that underlie long-distance social ties. In a more instrumental sense, they also allow migrants to gather first-hand information on the wellbeing of their families, the suitability of business opportunities and partners, and the overall socioeconomic 
conditions of their communities and could thus inform decisions to send money, invest in assets, and participate in collective development efforts.

The findings of studies of transnationalism literature suggest that cross-border activities are responsive to affective ties between migrants and their origin communities. Itzigsohn and Saucedo (2002) find that the maintenance of emotional and affective ties-what they call "linear transnationalism" - is an important predictor of sociocultural cross-border engagement. These affective connections are evident in other research on other kinds of transnational activities. Landolt et al. (1999: 312) argue that Salvadoran household-level transnational activities are motivated by "a deep sense of obligation" on the part of the immigrant. Guarnizo et al. (2003) find that the expectation that migrants return to their home communities is a strong predictor of transnational political engagement.

Sana's (2005) findings that remittances are motivated by status loss and discrimination at destination also indicate that migrants continue to see the home community as their valid reference group and draw their self-worth from home-community value systems. Ongoing social ties are also important for the maintenance of transnational engagement: Bloch's study of Zimbabweans in the UK shows that kinship ties and staying in touch with family in the origin community are important determinants of remitting. The common finding that married males have a high propensity for transnational activities (Guarnizo et al. 2003; Itzigsohn and Saucedo 2002) also reflects contexts of exit from which men migrate more often than women and in which migration may be a family survival strategy.

Affective ties to kin play a large role in structuring the transnational activities of Senegalese migrants. Riccio (2008) argues that the family is the mainstay of social organization for Senegalese both at home and abroad. Organized around communalism and a hierarchical structured solidarity, the family remains a durable social institution in Senegal (Beauchemin et al. 2013). Furthermore, emigration from Senegal is largely a family strategy, as migration is pursued by individual men with assistance from kin, and a desire to return home leads to a temporary socially expected duration of migration on the part of both the migrant and the family (Riccio 2008). The family is the main source of status for Senegalese migrants, and this connection precludes many migrants from constructing families or pursuing family reunification at destination (Beauchemin et al. 2013; Riccio 2008). Kane (2011) argues that these kinds of affective ties are crucial to Senegalese transnationalism: Senegalese migrants living abroad engage in transnational activities as a way to seek status from their contributions to their family in the homeland, often in preparation for an eventual return.

Other studies of transnationalism state that physical circulation between destination and origin is important in facilitating other transnational activities in instrumental, rather than affective, ways. Qualitative work has shown the importance of mobility for transnational political participation: Smith (2006) recounts that Mexican members of the Ticuani Solidarity Committee of New York would travel to Ticuani to consult with authorities and contractors on committee-funded public works projects over the weekend and would be back in New York in time for work on Monday morning. Riccio (2001) describes a similar situation for Senegalese 
migrants, who engage in what he calls "transnational livelihoods" that involve frequent trips back to Senegal to facilitate investments and other business dealings. Quantitative work often assumes the importance of cross-border travel but leaves it unanalyzed. Portes and associates (Portes et al. 2002; Portes and Zhou 2012) assert that transnational entrepreneurship is at least partially dependent on the ability to be physically present both "here" and "there," but the actual practice of short visits to the homeland is not included as a predictor variable in models. Waldinger (2008) analyzes the regularity and recency of home-country travel, but does not directly examine its effect on other cross-border activities.

Occasional physical presence in the homeland is thus of clear importance for the maintenance of affective social ties and the instrumental gathering of information, which are themselves the crucial social infrastructure of trasnational flows. The strand of transnational studies that celebrates the ability of new communications technologies to compress time and space in such a way as to allow ongoing crossborder activities thus excludes a potentially important determinant of such activities by minimizing the importance of physical travel between destination and the homeland. We would thus expect a positive direct effect of short returns on non-mobile transnational activities, such as remitting, investing, and participating in HTAs.

\subsection{Caging Non-mobile Transnational Activities}

A relationship between short visits to the origin community and other transnational activities opens the door to an important indirect effect of irregular legal statuses on cross-border engagement that does not directly depend on the physical crossing of borders (henceforth referred to as "non-mobile transnational activities"). Waldinger (2008) argues that states effectively "cage" migrants with irregular legal status by constraining their movement across borders. This caging not only limits their physical movement but also, by limiting physical co-presence with important people "back home," constrains their social ties to the homeland. Short returns home thus act as a mediator of irregular legal statuses. If migrants with irregular legal status experience territorial confinement that constrains their ability to circulate, and if short visits to the homeland allow migrants to maintain affective ties and gather information, and if these ties and information encourage migrants to participate in other forms of cross-border action, then migrants with irregular legal status should participate less in those forms of cross-border action that depend in some way on physical presence in the homeland.

While the literature is suggestive of this indirect effect of irregular legal status on non-mobile transnational activities, few studies have simultaneously examined the direct relationship between short returns and non-mobile transnational activities and the indirect relationship between irregular legal status and non-mobile transnational activities transmitted via inhibited cross-border mobility. Waldinger (2008: 24) notes that "better settled migrants with secure legal status are more likely to engage in activities requiring physical presence in the homeland," but he does not examine 
the impact that migrants' legal status has on both physical presence in the homeland and the activities that require such presence. This impels us to examine this indirect link and to hypothesize that irregular legal status will indirectly constrain nonmobile transnational activities. Senegalese migrants who do not have the ability to circulate between destination and origin because of their irregular legal status are effectively prevented from engaging in transnational livelihoods that depend on this circulation.

\subsection{Transnational Activities of Senegalese Migrants}

Senegalese migrants in Europe and across the globe have been noted for their regular and sustained participation in the lives of the kin and communities they left behind in their homeland. Studies of Senegalese migrants have argued that they live their lives across borders in multiple places simultaneously and that the dominant mode of organization of their migration experience is transnational (Kane 2011) with an overriding goal of creating economic, social, and spiritual lives in Senegal to which they hope to return (Riccio 2008). Indeed, Senegalese are quite active in a number of transnational spheres. Official monetary remittances to Senegal tripled between 2002 and 2008, rising from $\$ 305$ million to $\$ 1.2$ billion (Cisse 2011); and while the financial crisis of 2008 took its toll, estimates for 2017 still place official remittances at $\$ 2.3$ billion, or about 10\% of GDP (World Bank Group 2016, 2017).

In terms of the absolute value of remittance flows, Senegal ranks third in subSaharan Africa, behind only demographic giants Nigeria, and Ghana (World Bank Group 2016). In addition, official remittances are thought to make up only 54\% of total remittances. Research has highlighted the impacts of these monetary flows in Senegal at the household and macroeconomic level: remittances reduced poverty nation-wide by $30 \%$, and accounted for a large portion of national macroeconomic accounting, ahead of both foreign direct investment and official development assistance and equal to about $40 \%$ of export earnings (Cisse 2011).

The transnational activities of Senegalese migrants are not limited to remittances. Short visits to Senegal by migrants residing abroad are an integral part of what Kaag (2008) calls a "circular transnational livelihood," facilitating trade and other economic transactions (Riccio 2008). Recent quantitative work on Senegalese migration has shown that Senegalese are more likely than Ghanaians or Congolese to make visits to their home country: half of Senegalese migrants visit Senegal within 5 years of departure, while only a third of Ghanaians and $10 \%$ of Congolese do so (Schoumaker et al. 2013). Tall (2008) argues that urban migrants have invested a large proportion of their foreign earnings in real estate, and that these visible (and occasionally ostentatious) signs of success have played a large role in creating a "culture of migration" that sustains a transnational social field and quantitative research has recently found Senegalese migrants to have a high propensity to invest in Senegal (Schoumaker et al. 2013). 
Senegalese migrants also participate in a variety of transnational associations, which collect funds from migrants to promote construction of schools, health centers, roads, irrigation systems, and places of worship in their villages or hometowns, in addition to providing moral and financial support to co-national migrants at destination (Grillo and Riccio 2004; Kothari 2008). Their families also tend to be transnational: family reunification is lower among Senegalese migrants than among other African migrants in Europe, with spouses commonly remaining in Senegal (Schoumaker et al. 2013; Hannaford 2017). Senegalese migrants thus participate in a wide variety of transnational activities, lending credence to the assertion that they organize their migration strategies along transnational lines.

Despite the apparent ubiquity of transnational engagement among Senegalese migrants, studies have also demonstrated that these migrants' cross-border activities are constrained by their lack of secure legal status. Senegalese migrants without residence papers are "stuck" in their destination (Kaag 2008; Kane 2011): they do not have the legal ability to cross the border that separates them from their homeland. Riccio $(2001,2008)$ highlights the important role that acquisition of the permesso di soggiorno plays for Senegalese migrants in Italy: without it, they are not able to practice the circular transnational livelihoods that purportedly mark the Senegalese migration experience.

Lack of legal status constrains the mobile and non-mobile transnational activities of Senegalese migrants. This constraint is all the more important given the oftenprecarious legal situation in which Senegalese migrants in Europe find themselves (see Chap. 3 for an examination of the pathways into irregular status among Senegalese migrants). Senegalese have long been suspected of participating in "clandestine" or irregular migration strategies in Europe. Senegalese migrants were targets as "false tourists" in France during the late 1960s (Diop 1993; Spire 2005) and were publicly visible in the sans papiers movement in the 1990s (Timera 1997). Senegalese in Italy and Spain may have first entered these destinations in a quest for legal status through regularization programs and remain among the nationalities with the highest rates of irregularity.

This chapter explores the link between legal status and the transnational activities of Senegalese migrants in France, Italy, and Spain. While there is a voluminous research literature on the cross-border activities of migrants, few of these studies focus explicitly on the impact of migrants' legal statuses on their transnational engagement (Van Meeteren 2012). When the literature does mention legal status, it either simply assumes that irregular migrants are excluded from cross-border activities or finds that they are somehow structurally excluded without examining how this exclusion happens. Much of this lack of recognition of the role of legal status could be due to the apparent lack of a direct link between legal exclusion and crossborder participation. Many researchers may concur with Sciortino, who argues that "[1]egal status is significant, indeed relevant, only when and if - and to the degree to which - the legal reality is a constraint over the relationships and actions of the actor" (2004: 22) and assume that the legal reality is not a constraint over transnational action. This chapter explicitly examines the extent to which the legal reality is a constraint over this kind of action among Senegalese migrants in Europe. 


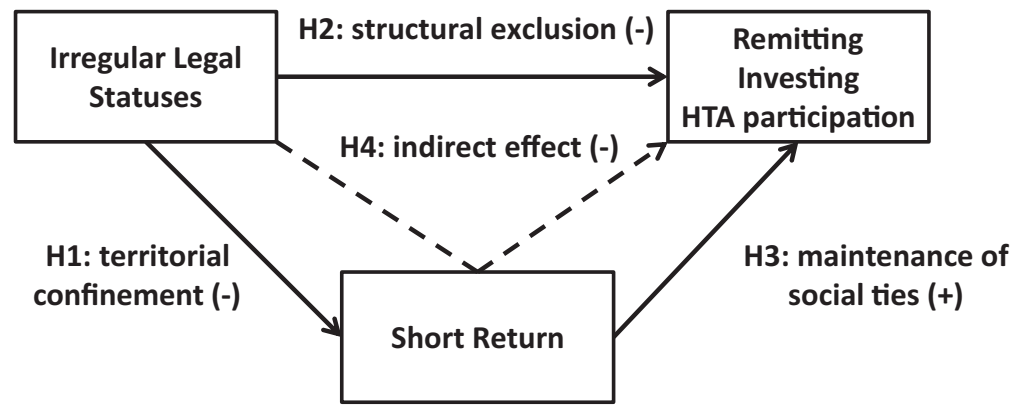

Fig. 5.1 Hypothesized relationships between irregular legal status and transnational activities

\subsection{Hypotheses}

Figure 5.1 summarizes the hypothesized relationships between irregular legal status and Senegalese migrants' cross-border engagement. The territorial confinement hypothesis (H1) posits a direct legal constraint of irregular status on migrants' short returns to Senegal. The structural exclusion (H2) hypothesis postulates a direct legal constraint of irregular status on migrants' abilities to participate in formal institutions that may promote non-mobile cross-border engagement; irregular status is thus a proxy for unmeasured blockages of participation in such institutions. The affective ties (H3) hypothesis suggests a link between short returns and non-mobile transnational activities - remitting, investing, and participation in hometown associations_-via the maintenance of affective links and the ability to gather first-hand information through occasional physical presence in the homeland. Finally, the caging hypothesis ( $\mathrm{H} 4)$ posits that the territorial confinement of migrants with irregular statuses (H1) constrains social ties with the homeland (H3) in a way that dampens non-mobile cross-border activities. The legal reality thus constrains cross-border action in a multitude of direct and indirect ways that depend, in part, on the crossing of physical and institutional borders.

\subsection{Data and Methods}

\subsubsection{Data Source}

The analyses performed in this chapter rely on a data from the Migration between Africa and Europe (MAFE-Senegal) project. While Chap. 1 describes the MAFE project in detail, this section highlights some additional features of the data that are pertinent for this chapter's analyses. The multi-sited character of the MAFE data avoids potential biases in the retrospective measurement of transnational activities by including individuals who have returned to Senegal after a stay in Europe. 
Furthermore, the inclusion of three different countries allows study of the extent to which transnational practices vary according to the context of reception, especially in relation to varying policy contexts regarding legal status. The retrospective nature of the data allows longitudinal and time-varying analyses, which are important as both legal status and transnational participation are likely to vary from year to year over a migrant's stay at destination.

\subsubsection{The Analytic Sample}

All person-years during which an individual was a migrant in France, Italy, or Spain contribute to this chapter's analyses. The sample thus includes person-years contributed by return migrants in Senegal who spent time in one or more of the three European countries. Migrants interviewed in any of the European countries may also contribute person-years to the analysis of other countries if they previously spent time in those countries (i.e., migrants can have more than one trip). The total analytic sample comprises 658 individuals contributing 8188 person-years. The French subsample contains 264 individuals and 3677 person-years, the Italian subsample contains 200 individuals and 2413 person-years, and the Spanish subsample comprises 198 individuals and 2098 person-years.

\subsubsection{Outcome Variables}

Modules of the MAFE biographical questionnaire gathered information on migrants' transnational practices, including short returns to Senegal, remittances, investments, and participation in associations (see Appendix B for the wording of the questions). The outcome variables in this chapter are four separate time-varying indicators of four types of transnational activities among Senegalese migrants in France, Italy, and Spain.

For short returns, the interviewer asked migrants in which year(s) they returned to Senegal while living abroad. A dichotomous variable indicates a short return to Senegal for each year in which a visit took place (with " 1 " indicating a visit and "0" indicating no visit).

For remittances, the interviewer asked if the individual regularly sent money to someone who lived in a different country, and, if so, during which periods and to which country. A dichotomous variable indicates remittances to individuals in Senegal for each year in which a migrant reported sending money to someone living there (with " 1 " indicating remitting and " 0 " indicating no remitting). This variable captures the directionality and regularity of remittances, but not the amount remitted.

Investments were measured by asking individuals if they had ever owned (through gifting, inheritance, or purchase) assets in Senegal or elsewhere, and if so, 
when they owned the asset. A dichotomous variable indicates ownership of at least one asset in Senegal purchased while the migrant lived abroad for each year in which a migrant reported owning an asset there (with "1" indicating ownership and " 0 " indicating no ownership). This variable excludes inheritances or gifts.

For hometown associations (HTAs), migrants indicated the years during which they participated financially, via contributions or membership fees, in associations that finance projects in Senegal or support Senegalese migrants in Europe. A dichotomous variable indicates HTA participation for each year in which a migrant contributes to such associations (with " 1 " indicating participation and " 0 " indicating no participation).

\subsubsection{Predictor Variables}

The main predictor variable of interest is the contexts of reception faced by Senegalese migrants is their legal status. As described in Chap. 3, administrative histories in the MAFE questionnaire provided information on migrants' statuses in the legal domains of entry, residence, and work authorization. This chapter uses the typology of legal statuses developed in Chap. 3. This typology includes indicators of entry status and yearly combined residence and work authorizations. A dichotomous variable indicates entry status as visa $(\mathrm{V})$ or no visa $(\mathrm{NV})$ based on migrants' responses about whether or not they had a visa when they entered the destination country; this variable is thus defined for the year of arrival for each trip. A composite categorical variable indicates legal status in each year during the migrant's residence in a destination: RP_WP ("fully regular status"), NRP_WP ("mixed status, no residence permit"), RP_NWP ("mixed status, no work permit"), NRP_NWP ("fully irregular status"). As outlined in Chap. 3, this categorical variable varies over time.

Other facets of the context of reception include: a time-varying categorical variable indicating the migrant's employment status (employed or unemployed, with inactive as the reference category); a time-varying dummy variable indicated the migrant's occupation, comparing entrepreneurial self-employment, noted in the literature as being conducive to Senegalese migrants" "transnational livelihood," to all other types of employment; a time-varying dichotomous variable measures selfreported economic status, with having the financial ability to cover basic needs being better than others in the same location compared to lesser self-reported status; and a time-varying count of family members or friends residing in the same country as the migrant captures potential effects of social networks. In addition to the above variables measuring the context of reception, dummy variables for residence in Italy and Spain in a given year (with France as the reference category) enter into the models to measure heterogeneity between these destinations not already captured by individual-level variables. 
Variables measuring years in destination, years of education, sex, and age capture individual characteristics expected to be associated with higher propensity to engage in transnational activities. Years in destination is measured as completed years since arrival at a particular year's destination, and this metric is "reset" for each subsequent stay in a different destination; the models include a quadratic term on years in destination to account for potential non-linearities in its effect. Years of education is measured as an interval variable. In order to avoid age-period-cohort collinearities with other variables, age at migration-which remains fixed over a given migration spell for an individual but then changes if the same individual migrates to another destination-enters the eq. A variable measuring number of previous migrations to Europe captures migration-specific human and social capital accumulated by an individual over multiple trips.

Research on Senegalese migration and transnationalism shows evidence of differential effects by ethnicity, so a dichotomous variable indicates Senegalese ethnic group: Wolof, with other ethnic groups (including Mandingue, Pular, Soninké, and other) as the reference category. ${ }^{1}$ Research has also shown that religion, especially membership in Islamic Sufi brotherhoods, plays an important role in structuring Senegalese transnationalism (Riccio 2001). The model thus includes a dummy for belonging to the Mouride brotherhood, with all other religious categories (including Tidiane, Layene, other Muslim, and not Muslim) as the reference group.

A set of time-varying indicators of the migrant's familial connections with individuals in Senegal measures affective links to the home community, including having a spouse in Senegal, having children in Senegal, and having at least one parent alive in Senegal. A dummy variable indicating family contributions to the financing of the migrant's trip (which can vary for each trip) captures instrumental or contractual relationships with the family that might be expected to structure some kinds of transnational activities (Chort et al. 2012). A variable indicating the migrant's identification of Dakar - far and away the country's most important urban area-as place of origin measures the different geographical zones corresponding to different migration streams from Senegal. A dummy for father's schooling (less than secondary school) measures the socioeconomic status of the sending family.

The dichotomous time-varying indicator for short returns was included in the model for the non-mobile transnational activities of remitting, investing, and HTA participation, allowing testing of hypotheses 3 and 4 .

To account for potential period effects on the propensity to engage in transnational activities, a dummy indicates arrival in the 1990 s or 2000 s, with arrivals prior to 1990 as the reference category. This choice of categories stems from the change in profile of Senegalese migrants in the 1990s, which corresponded to a change in social origins and destinations in Europe (Schoumaker et al. 2013).

\footnotetext{
${ }^{1}$ Qualitative research on Senegalese transnationalism has found that Senegalese in the new destination of Italy are extremely likely to participate in "transnational livelihoods" (Riccio 2008). As Senegalese in Italy tend to be from the Wolof ethnic group and adherents of the Mouride brotherhood, these modalities are tested as variables in the models.
} 


\subsubsection{Models}

Exploiting the longitudinal and time-varying nature of both outcome and explanatory variables requires methods that account for clustering of repeated observations of the same individual. Regular generalized linear models make the important assumption of conditional independence between observations. Such models, however, are unsuitable for data featuring repeated observations on the same individual, which are likely to violate the assumption of independence. ${ }^{2}$ Including a personspecific random intercept in the model, however, allows the dependence to be captured (Rabe-Hesketh and Skrondal 2008). This model can be written as

$$
\operatorname{logit}\left\{\operatorname{Pr}\left(y_{i t}=1 \mid \mathbf{x}_{i t}, \zeta_{i}\right)\right\}=\beta_{1}+\mathbf{x}_{i}^{\prime} \beta_{2}+\mathbf{x}_{i t}^{\prime} \beta_{3}+\zeta_{i}
$$

where $y_{i t}$ is the dichotomous outcome indicator of participation in a given transnational activity for person $i$ during year $t, \beta_{1}$ is a constant, $\mathbf{x}_{i}^{\prime}$ is a vector of timeconstant explanatory variables, $\mathbf{x}_{i t}^{\prime}$ is a vector of time-varying explanatory variables, $\beta_{2}$ and $\beta_{3}$ are regression coefficients, and $\zeta_{i}$ is the person-specific random intercept. All outcome and predictor variables are observed at time $t{ }^{3}$ The random intercept $\zeta_{i}$ is assumed to be independent across respondents $i$ and conditionally normally distributed with mean zero and variance $\psi$.

$$
\zeta_{i} \mid \mathbf{x}_{i t} \sim N(0, \psi)
$$

The person-specific random intercept induces the dependence between repeated observations, and can also be thought of as capturing unobserved heterogeneity in the propensity to engage in the outcome (Rabe-Hesketh and Skrondal 2008).

I estimate a random intercept model for each of my four outcome variables on the pooled three-country sample using adaptive Gauss-Hermite quadrature to approximate the likelihood function (Rabe-Hesketh and Skrondal 2008). Sensitivity tests indicated 48 quadrature points were appropriate for fitting the models accurately.

Dependence among the dichotomous responses for the same person can be summarized by the residual intraclass correlation $(\rho)$ of the underlying latent outcome variable given the explanatory variables:

\footnotetext{
${ }^{2}$ Models from previous chapters of this book either used dynamic survival models that do not violate assumptions of independence or selected cross-sectional samples of the data and thus did not need to account for repeated observations on the same individual. All models in previous chapters included corrections to standard errors to account for clustering arising from including multiple trips for individuals, but that clustering is a distinct phenomenon from the variety considered here.

${ }^{3}$ All models were also estimated with lagged predictors measured at time $t-1$ but results (not reported, available upon request) were substantively similar.
} 


$$
\rho=\frac{\psi}{\psi+\pi^{2} / 3}
$$

Intraclass correlation for dichotomous outcomes is expressed in terms of the latent responses because intraclass correlation for observed outcomes varies according to the values of the predictor variables. Rodríguez and Elo (2003) propose setting the observed predictors to the selected percentiles (such as the median) in order to allow for examination of this correlation for the manifest (observed) outcome. These measures of unobserved heterogeneity help quantify the extent to which individuals are prone to engage in transnational activities even after accounting for observed covariates. In the case of high intraclass correlation, it is possible that individuals have intrinsically high or low probabilities of engaging in certain transnational activities.

\subsubsection{Estimating Indirect Effects in a Non-linear Framework}

The caging hypothesis posits an indirect effect of legal statuses on non-mobile transnational activities via the mediating variable of short returns. Estimation of this indirect effect is straightforward in an ordinary least squares (OLS) model: the difference in the coefficients for the legal-status variables in models with (the "reduced model") and without (the "full model") the mediator variable (here, short returns) can be considered the indirect effect of that variable. In a non-linear framework, however, the underlying latent variable has a scale that is unknown and depends on the predictors included in the model. Calculating indirect effects in nonlinear models using techniques developed for linear regression thus conflates rescaling with mediation (Karlson and Holm 2011; Mood 2010).

Kohler, Karlson, and Holm propose a method (hereafter, "KHB method") for effect decomposition in a non-linear framework (Kohler et al. 2011). They propose extracting the information that is not contained in the predictor variable of interest from mediator by calculating the residuals of a regression of the mediator on the predictor variable of interest and using the residuals of this regression, which have the same standard deviation as the mediator variable itself and thus induce the same scale for the coefficients, in the reduced model. The KHB method allows the calculation of the indirect effects of legal statuses on non-mobile transnational activities as transmitted by the mediator variable of short visits to the homeland. 


\subsection{Results}

\subsubsection{Descriptive Results}

Descriptive results provide support for the first two hypotheses: migrants with irregular status return home less frequently, indicating that territorial confinement accompanies these irregular statuses; and migrants with irregular statuses participate less frequently in non-mobile transnational activities, indicating that their lack of secure legal status directly blocks them from cross-border action. Table 5.1 presents weighted ${ }^{4}$ descriptive statistics by legal status for the analytic sample under study. The outcome variables indicating transnational activities are represented by the proportion of person-years in which migrants engaged in each activity. These descriptive statistics indicate significant variation in the prevalence of each activity. On average, Senegalese migrants remit in about $72 \%$ of the person-years, while they engage in the other transnational activities much less frequently. Short returns occur in about $30 \%$ of person-years, migrants report owning assets in Senegal about $25 \%$ of the time, and they participate in HTAs in about $19 \%$ of person-years. In addition, this table indicates that there is significant variation in the prevalence of these activities across legal statuses, with $F$-statistics all significant at $p<0.001$.

Migrants with fully regular (RP_WP) legal status are the most likely to visit the homeland, remit, and invest, while migrants with fully irregular (NRP_NWP) status are the least likely to participate in all of the transnational activities. Those migrants with only work authorization (NRP_WP) are the most likely to participate in associations. Migrants with only residence authorization (RP_NWP) are less likely than migrants with either fully regular status or work-only authorization to engage in all transnational activities. This is even true for visits to the homeland: migrants with only a residence permit reports such visits less frequently than migrants with only a work permit, indicating that a residence permit in and of itself, which should grant the legal ability to circulate, is not sufficient for successful circulation. Indeed, migrants with both a residence and a work permit report short returns to Senegal in almost $39 \%$ of person-years, indicating that fully regular status is positively associated with visits home. The descriptive evidence supports the hypothesis that those migrants who make short returns home have a higher propensity to engage in nonmobile transnational activities. Figure 5.2 displays variation in transnational activities conditional on legal status. The figure suggests that migrants with fully regular legal status are more likely to participate in each transnational activity than migrants with fully regular legal status. In addition, in most cases, migrants with fully regular status are also more likely to participate in these activities than migrants with mixed statuses.

The descriptive statistics also support the hypothesis of an indirect effect of territorial confinement on remitting, investing, and HTA participation via the inhibi-

\footnotetext{
${ }^{4}$ Normalized sampling weights were applied to the data. See Schoumaker and Mezger (2013) for a description of the calculation and use of weights with the MAFE data.
} 
Table 5.1 Descriptive statistics for MAFE-Senegal sample, by legal status

\begin{tabular}{|c|c|c|c|c|c|c|c|c|c|c|}
\hline \multirow[b]{3}{*}{ Variable } & \multicolumn{8}{|c|}{ Legal status } & \multirow{2}{*}{\multicolumn{2}{|c|}{ Total }} \\
\hline & \multicolumn{2}{|c|}{$\begin{array}{l}\text { Fully } \\
\text { irregular }\end{array}$} & \multicolumn{2}{|c|}{$\begin{array}{l}\text { Mixed (no } \\
\text { RP) }\end{array}$} & \multicolumn{2}{|c|}{$\begin{array}{l}\text { Mixed (no } \\
\text { WP) }\end{array}$} & \multicolumn{2}{|c|}{\begin{tabular}{|l} 
Fully \\
regular
\end{tabular}} & & \\
\hline & Mean & SD & Mean & SD & Mean & SD & Mean & SD & Mean & SD \\
\hline Short returns & 0.04 & 0.21 & 0.23 & 0.42 & 0.20 & 0.40 & 0.39 & 0.49 & 0.30 & 0.46 \\
\hline Remitting to Senegal & 0.55 & 0.50 & 0.77 & 0.42 & 0.57 & 0.49 & 0.77 & 0.42 & 0.72 & 0.45 \\
\hline Asset ownership in Senegal & 0.10 & 0.29 & 0.24 & 0.43 & 0.22 & 0.41 & 0.29 & 0.45 & 0.24 & 0.43 \\
\hline HTA financial participation & 0.07 & 0.25 & 0.28 & 0.45 & 0.14 & 0.35 & 0.22 & 0.42 & 0.19 & 0.39 \\
\hline $\begin{array}{l}\text { Legal status: fully irregular } \\
\text { (NRP_NWP) }\end{array}$ & 1 & 0 & 0 & 0 & 0 & 0 & 0 & 0 & 0.17 & 0.38 \\
\hline $\begin{array}{l}\text { Legal } \\
\text { status: mixed (NRP_WP) }\end{array}$ & 0 & 0 & 1 & 0 & 0 & 0 & 0 & 0 & 0.039 & 0.19 \\
\hline $\begin{array}{l}\text { Legal } \\
\text { status: mixed (RP_NWP) }\end{array}$ & 0 & 0 & 0 & 0 & 1 & 0 & 0 & 0 & 0.099 & 0.30 \\
\hline $\begin{array}{l}\text { Legal status: fully regular } \\
\text { (RP_WP) }\end{array}$ & 0 & 0 & 0 & 0 & 0 & 0 & 1 & 0 & 0.69 & 0.46 \\
\hline Entry status: no visa & 0.47 & 0.50 & 0.11 & 0.32 & 0.49 & 0.50 & 0.41 & 0.49 & 0.41 & 0.49 \\
\hline Destination: France & 0.48 & 0.50 & 0.49 & 0.50 & 0.62 & 0.49 & 0.64 & 0.48 & 0.61 & 0.49 \\
\hline Destination: Spain & 0.23 & 0.42 & 0.10 & 0.30 & 0.082 & 0.27 & 0.14 & 0.35 & 0.15 & 0.35 \\
\hline Destination: Italy & 0.30 & 0.46 & 0.40 & 0.49 & 0.30 & 0.46 & 0.22 & 0.41 & 0.25 & 0.43 \\
\hline Years in destination & 4.03 & 3.64 & 8.25 & 6.93 & 8.85 & 8.06 & 11.1 & 8.37 & 9.56 & 8.13 \\
\hline Period of arrival: post-1990 & 0.73 & 0.45 & 0.51 & 0.50 & 0.51 & 0.50 & 0.47 & 0.50 & 0.52 & 0.50 \\
\hline $\begin{array}{l}\text { Age at start of current } \\
\text { migration spell }\end{array}$ & 27.1 & 7.88 & 26.7 & 5.60 & 27.8 & 6.69 & 26.8 & 6.83 & 26.9 & 6.97 \\
\hline Sex: Male & 0.70 & 0.46 & 0.80 & 0.40 & 0.63 & 0.48 & 0.71 & 0.46 & 0.70 & 0.46 \\
\hline Years of education & 8.46 & 5.84 & 7.74 & 6.24 & 8.86 & 7.14 & 9.60 & 6.17 & 9.27 & 6.25 \\
\hline Ethnicity: Wolof & 0.55 & 0.50 & 0.51 & 0.50 & 0.50 & 0.50 & 0.42 & 0.49 & 0.45 & 0.50 \\
\hline Religion: Mouride & 0.50 & 0.50 & 0.46 & 0.50 & 0.33 & 0.47 & 0.29 & 0.45 & 0.34 & 0.47 \\
\hline Unemployed & 0.05 & 0.22 & 0.03 & 0.16 & 0.015 & 0.12 & 0.025 & 0.16 & 0.03 & 0.17 \\
\hline Employed & 0.77 & 0.42 & 0.92 & 0.28 & 0.72 & 0.45 & 0.84 & 0.37 & 0.82 & 0.39 \\
\hline Inactive & 0.18 & 0.39 & 0.058 & 0.23 & 0.27 & 0.44 & 0.14 & 0.34 & 0.15 & 0.36 \\
\hline Occupation: self-employed & 0.26 & 0.44 & 0.20 & 0.40 & 0.16 & 0.37 & 0.08 & 0.27 & 0.12 & 0.33 \\
\hline $\begin{array}{l}\text { Self-reported economic } \\
\text { status: good }\end{array}$ & 0.12 & 0.33 & 0.05 & 0.22 & 0.06 & 0.23 & 0.07 & 0.25 & 0.08 & 0.26 \\
\hline $\begin{array}{l}\text { Number of contacts at } \\
\text { destination }\end{array}$ & 2.03 & 2.02 & 1.94 & 2.15 & 3.07 & 2.55 & 3.68 & 2.78 & 3.27 & 2.71 \\
\hline Number of trips & 1.57 & 0.82 & 1.29 & 0.73 & 1.56 & 0.95 & 1.43 & 0.96 & 1.46 & 0.93 \\
\hline $\begin{array}{l}\text { Does not speak language of } \\
\text { destination }\end{array}$ & 0.41 & 0.49 & 0.29 & 0.46 & 0.36 & 0.48 & 0.23 & 0.42 & 0.28 & 0.45 \\
\hline Kids in Senegal & 0.40 & 0.49 & 0.39 & 0.49 & 0.37 & 0.48 & 0.29 & 0.45 & 0.32 & 0.47 \\
\hline Spouse in Senegal & 0.39 & 0.49 & 0.42 & 0.49 & 0.32 & 0.47 & 0.32 & 0.47 & 0.34 & 0.47 \\
\hline $\begin{array}{l}\text { Geographic origin: from } \\
\text { Dakar }\end{array}$ & 0.31 & 0.46 & 0.26 & 0.44 & 0.28 & 0.45 & 0.28 & 0.45 & 0.28 & 0.45 \\
\hline $\begin{array}{l}\text { Father's ed.: less than } \\
\text { secondary school }\end{array}$ & 0.72 & 0.45 & 0.75 & 0.43 & 0.67 & 0.47 & 0.67 & 0.47 & 0.68 & 0.47 \\
\hline
\end{tabular}


Table 5.1 (continued)

\begin{tabular}{|c|c|c|c|c|c|c|c|c|c|c|}
\hline \multirow[b]{3}{*}{ Variable } & \multicolumn{8}{|c|}{ Legal status } & \multirow{2}{*}{\multicolumn{2}{|c|}{ Total }} \\
\hline & \multicolumn{2}{|c|}{$\begin{array}{l}\text { Fully } \\
\text { irregular }\end{array}$} & \multicolumn{2}{|c|}{$\begin{array}{l}\text { Mixed (no } \\
\text { RP) }\end{array}$} & \multicolumn{2}{|c|}{$\begin{array}{l}\text { Mixed (no } \\
\text { WP) }\end{array}$} & \multicolumn{2}{|c|}{$\begin{array}{l}\text { Fully } \\
\text { regular }\end{array}$} & & \\
\hline & Mean & SD & Mean & SD & Mean & SD & Mean & SD & Mean & SD \\
\hline Trip paid by family & 0.32 & 0.47 & 0.24 & 0.43 & 0.49 & 0.50 & 0.41 & 0.49 & 0.40 & 0.49 \\
\hline Plan to stay: definitive & 0.53 & 0.50 & 0.32 & 0.47 & 0.37 & 0.48 & 0.45 & 0.50 & 0.45 & 0.50 \\
\hline $\begin{array}{l}\text { Trip motivation: work/better } \\
\text { life }\end{array}$ & 0.62 & 0.49 & 0.76 & 0.43 & 0.42 & 0.49 & 0.56 & 0.50 & 0.56 & 0.50 \\
\hline $\begin{array}{l}\text { At least one parent alive in } \\
\text { Senegal }\end{array}$ & 0.86 & 0.35 & 0.91 & 0.29 & 0.89 & 0.32 & 0.77 & 0.42 & 0.80 & 0.40 \\
\hline $\mathrm{N}$ (person-years) & \multicolumn{2}{|l|}{1448} & \multicolumn{2}{|l|}{307} & \multicolumn{2}{|l|}{937} & \multicolumn{2}{|l|}{5496} & \multicolumn{2}{|l|}{8188} \\
\hline $\mathrm{N}$ (trips) & \multicolumn{10}{|l|}{768} \\
\hline
\end{tabular}

Source: MAFE-Senegal

Notes: Sampling probability weights applied

short returns

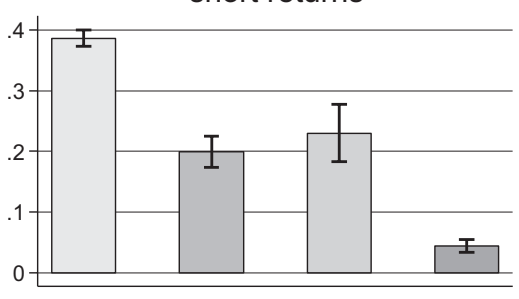

investing

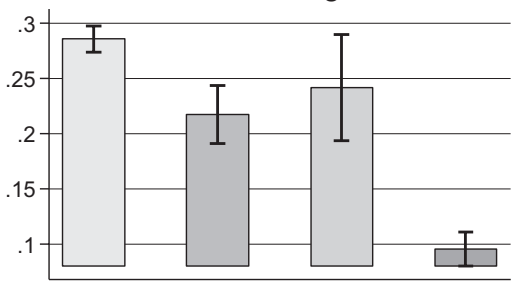

Fully regular

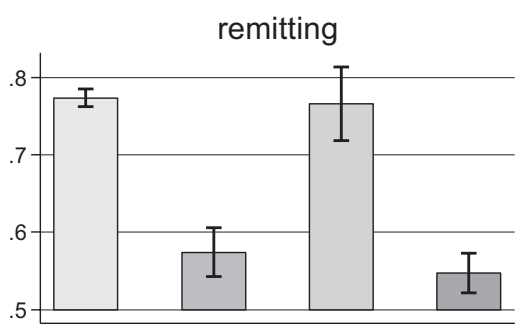

HTA participation

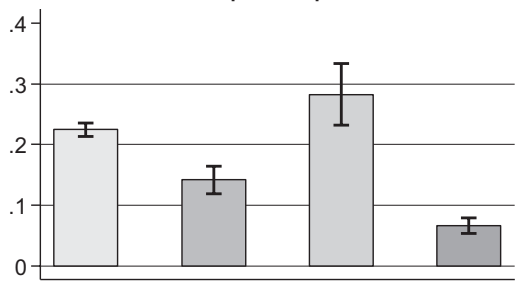

Mixed (no RP)

Fully irregular

Fig. 5.2 Average level of transnational activities, by legal status, with 95\% confidence intervals. (Source: MAFE-Senegal. Weighted data computed over person-years. 95\% confidence intervals displayed) 
tion of short returns. Figure 5.3 shows the variation in transnational activities conditional on both short returns legal status. Variation in non-mobile transnational activities by cross-border mobility is evident as in the previous figure: migrants who circulate are more likely to remit, invest, and participate in HTAs. In addition, this figure shows that legal status can operate through short returns to constrain nonmobile transnational activities: migrants who lack secure legal status and, as a result, do not visit the homeland engage in non-mobile transnational activities less frequently.

\subsubsection{Multivariate Results}

Table 5.2 displays results from the random-intercept logistic regression of each yearly transnational activity. In these multivariate models, results are displayed as average marginal effects (AMEs). While Chap. 3 outlines the rationale for presenting results as AMEs instead of logistic-regression coefficients or odds ratios, it is useful to review here some of their advantages. AMEs are useful for the interpretation of non-linear models and capture the expected change in the probability of the outcome associated with a one-unit or discrete change in a predictor variable (see Cameron and Trivedi 2010 for more information on average marginal effects).
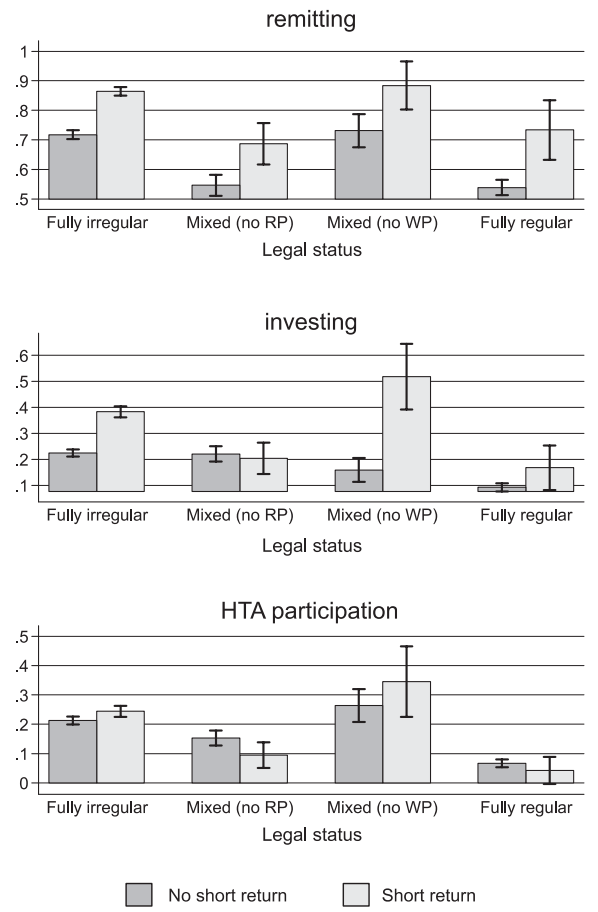

Fig. 5.3 Average level of transnational activities, by short return and legal status, with $95 \%$ confidence intervals. (Source: MAFE-Senegal. Weighted data computed over person-years. 95\% confidence intervals displayed) 


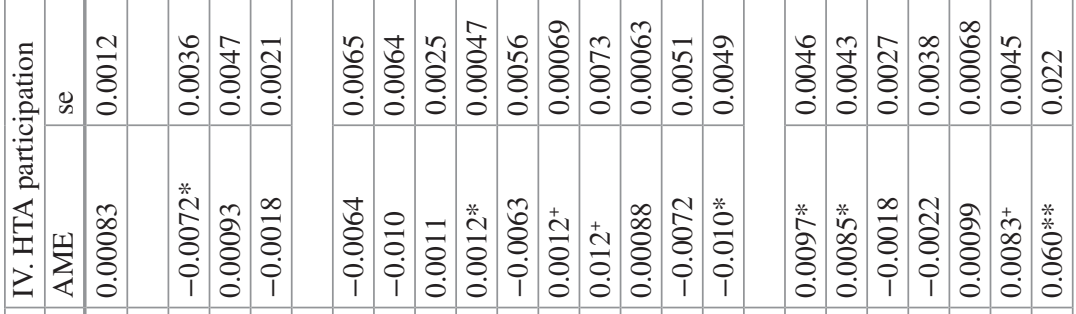

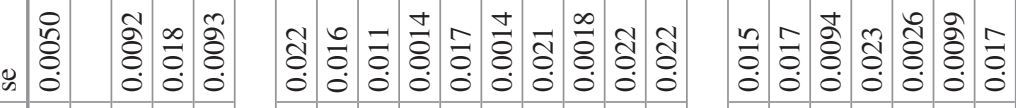

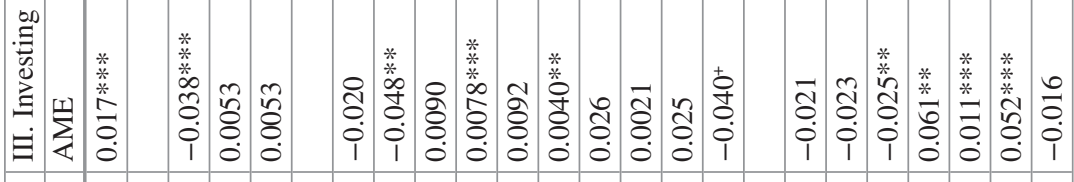

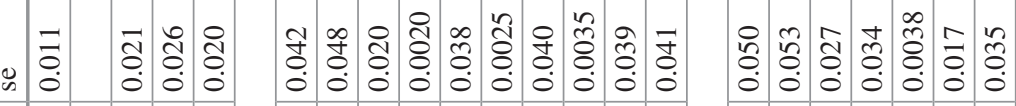

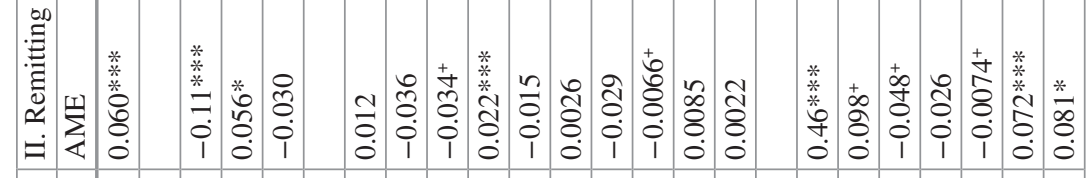

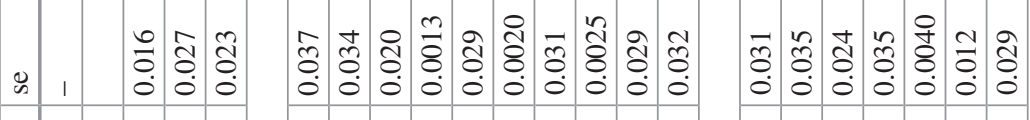
章

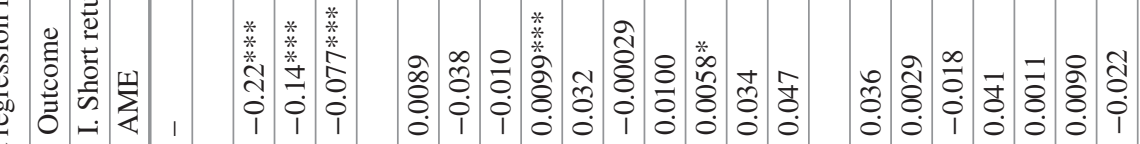
莕

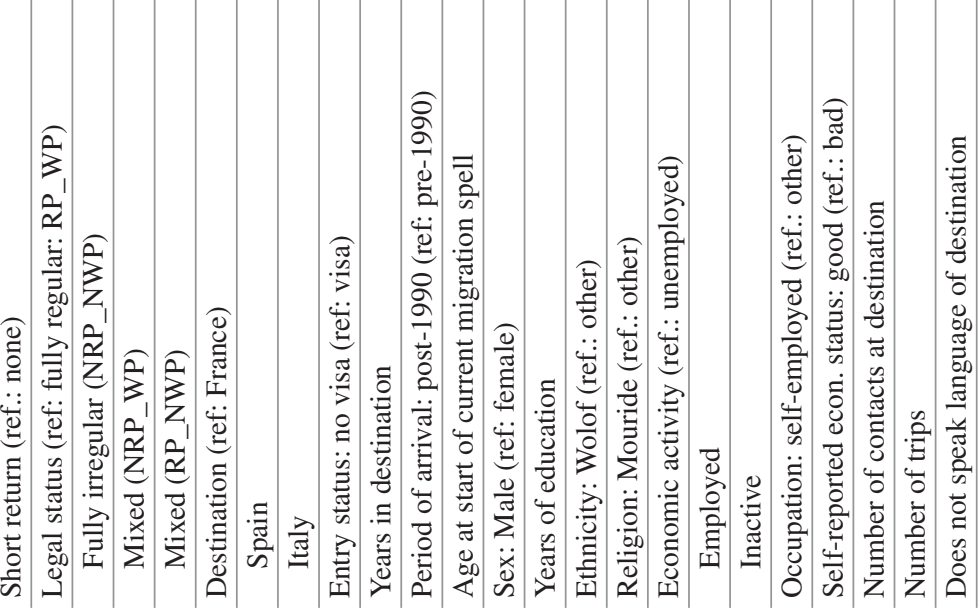




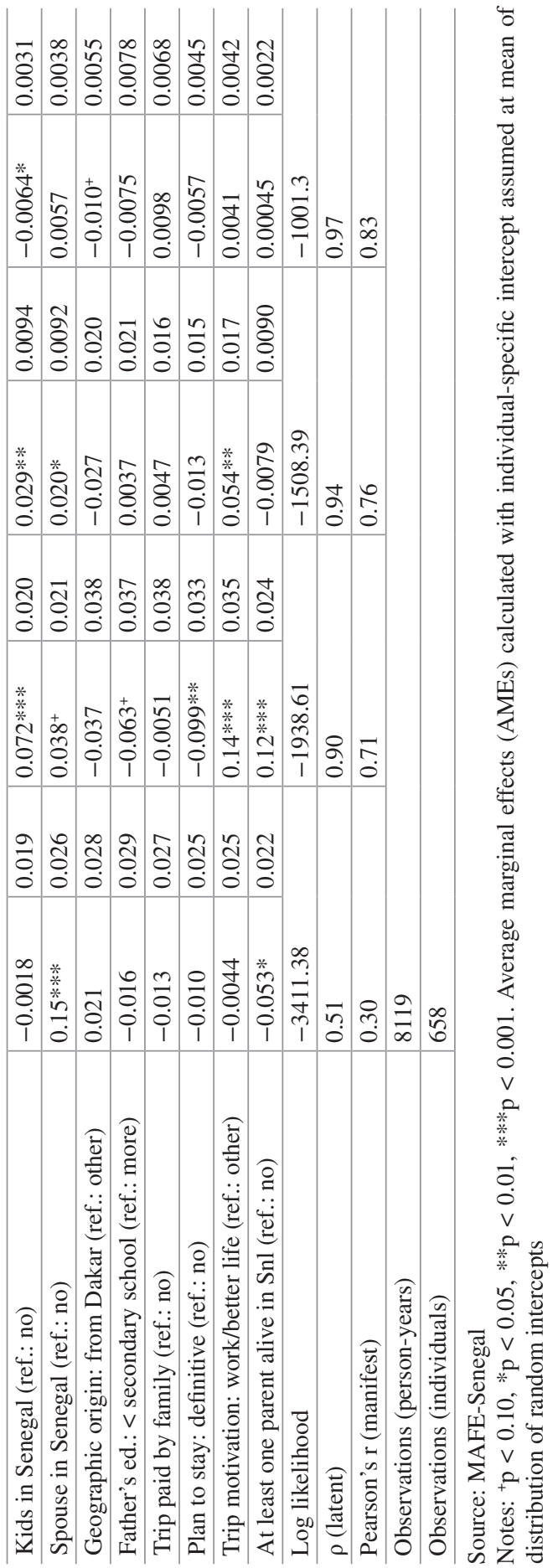


Mood (2010) argues that AMEs are appropriate for non-linear model comparisons, which is helpful when comparing the effect of a given variable across different models (the case of short returns here). For these random-effects models, AMEs are calculated assuming that the group-specific intercept is set at the mean of the distribution of the random intercepts (i.e., zero). It is also useful to note that the results are subject-specific probabilities, and not population-average probabilities: they refer to the yearly individual probability of engaging in each transnational activity.

Each model's residual intra-class correlation $(\rho)$ is also listed and is indicative of the degree to which the latent variable underlying each outcome is correlated across years for the same individual and can be interpreted in a way analogous to a Pearson correlation coefficient. Short returns has the lowest intra-class correlation at $\rho=0.51$, but the correlation at the level of the manifest outcome is lower, at 0.30; this indicates a fairly low within-person manifest correlation, with short returns on one occasion predicting $9 \%$ of the variability in short returns on a second occasion. Remitting and investing both have latent intraclass correlations of around 0.9, with lower manifest correlations of 0.71 for remitting and 0.76 for investing, indicating $\mathrm{R}^{2} \mathrm{~s}$ of 0.58 and 0.69 , respectively. HTA participation has the highest intra-class correlation at 0.97 , with a manifest correlation at the median of the predictors of 0.83 . This high correlation between yearly outcomes for this activity over time within individuals means that $69 \%$ of the variability in HTA participation is accounted for by previous participation. The within-subject dependence of transnational activities is thus much higher for remitting, investing, and HTA participation than for short returns. These intra-class correlations reinforce the importance of using a model that takes this high degree of within-individual clustering into account.

The following discussion of multivariate results will focus principally on the relationship between legal status and the probability of engaging in each of the four transnational activities in any given person-year. The base category for the composite legal-status variable is fully regular status, wherein migrants have both residence and work permits (RP_WP). The models also include a dichotomous variable for whether or not the migrant had a visa upon entry to the destination.

\section{Hypothesis 1: Territorial Confinement}

\section{Short Returns}

The descriptive results provided some measure of support for the hypothesis of territorial confinement: Senegalese migrants with fully regular (RP_WP) status are the most likely to make short visits home, while those migrants with irregular statuses, and especially migrants completely bereft of regular status, have a much lower likelihood of circulation. These results are overall averages, however, and do not take into account the clustered nature of the data nor the potential confounding effects of other predictors. Model I of Table 5.2 shows the results of the multivariate randomintercept logistic regression of yearly reports of short returns. 


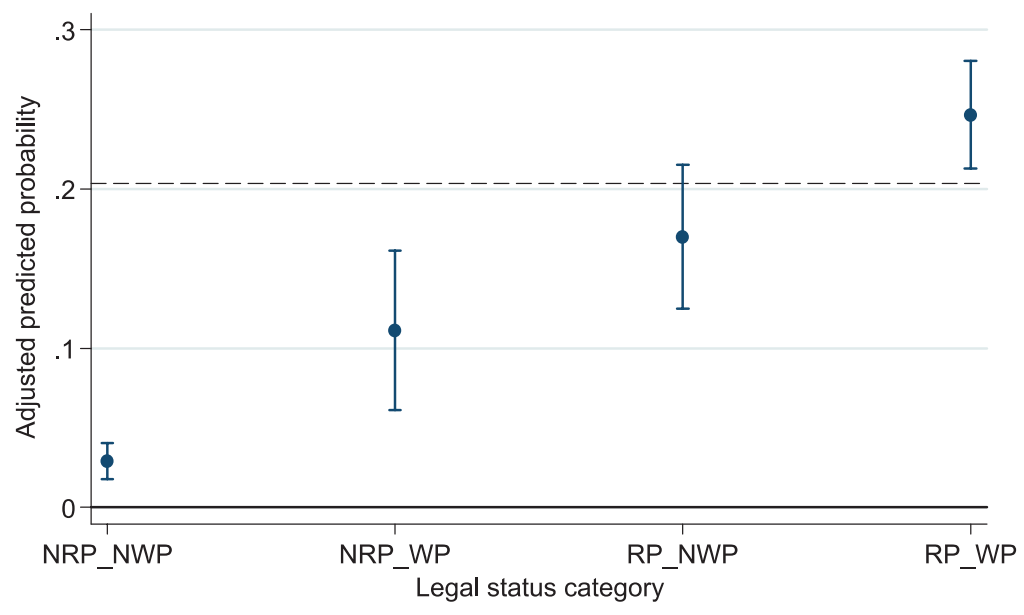

Fig. 5.4 Predicted probability of short return, by legal status category, with $95 \%$ confidence intervals (Dashed line represents grand mean of short returns)

These results indicate that the association between legal status and visiting the homeland is robust: compared to migrants with fully regular (RP_WP) status, those migrants with fully irregular or mixed statuses are statistically significantly less likely to circulate. Senegalese migrants with fully irregular (NRP_NWP) status are 22 percentage points less likely to report a visit to Senegal in any given year than migrants with fully regular (RP_WP) status. As Fig. 5.4 shows, this translates into a subject-specific predicted probability of circulation for migrants with fully irregular status of $3 \%$, while those migrants with both residence and work authorization have a subject-specific predicted probability of roughly $25 \%$; having fully regular status is thus associated with a seven-fold increase in the probability of making a visit home compared to having fully irregular status. Senegalese migrants who lack any kind of legal authorization have little chance of visiting the homeland because they are largely confined to the territory of the countries in which they reside.

Table 5.2 also indicates that migrants with semi-irregular or mixed statuses are also less likely than migrants with fully regular status to circulate between destination and origin. Lacking only a residence permit (NRP_WP) is associated with a 14-percentage-point gap in the probability of visiting the homeland compared to migrants with fully regular status, while lacking only a work permit (RP_NWP) is associated with an 8-point gap. Although Senegalese migrants with these mixed statuses have a higher predicted probability of circulating than migrants with fully irregular status, they still experience a degree of territorial confinement compared to migrants with fully regular status. Figure 5.4 shows that migrants with mixed status have a predicted probability of circulating of between $11 \%$ and $17 \%$. While yearly legal status clearly has a robust association with short returns, visa status at entry was not significantly associated with this outcome.

The model also indicates that there is no significant variation in the probability of short returns between destination countries, and additional models (not reported) 
failed to find a significant interaction between the legal-status and destination predictors. These multivariate results thus support the hypothesis of territorial confinement: Senegalese migrants who lack one or both forms of authorization are significantly less likely to engage in short returns to Senegal, and that this effect is constant across destinations. The legal reality that creates these irregular statuses thus functions as an important constraint on this physical, mobile form of crossborder action.

\section{Hypothesis 2: Blocked Transnationalism/Structural Exclusion}

Blocked transnationalism/structural exclusion was evident in the descriptive results: Senegalese migrants with fully regular (RP_WP) status were the most likely to engage in the non-mobile transnational activities of remitting, investing, and HTA participation, while migrants with fully or semi-irregular statuses were less likely to participate in these activities. This blockage as a result of lack of secure legal status is also evident in the multivariate results of Table 5.2.

\section{Remitting}

Model II of Table 5.2 shows the results of the random-intercept logistic regression of yearly reports of remitting. Compared to migrants with fully regular (RP_WP) status, those migrants with fully irregular (NRP_NWP) status are almost 10 percentage points less likely to report remitting in any given year. As Fig. 5.5 shows, this translates into a subject-specific predicted probability of remitting of $69 \%$ for

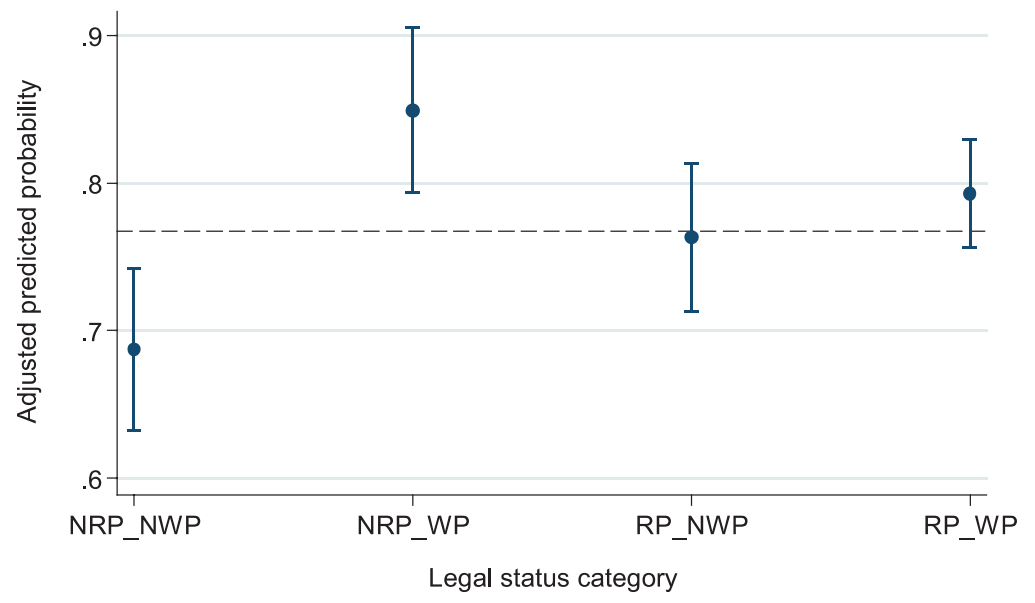

Fig. 5.5 Predicted probability of remitting by legal status category, with $95 \%$ confidence intervals (Dashed line represents grand mean of remitting) 
Senegalese migrants who lack both forms of authorization, compared to a predicted probability of almost $80 \%$ for migrants with fully regular status. Senegalese migrants who lack any form of legal authorization thus experience some kind of structural exclusion as a result of this status that is associated with a lower probability of remitting. It is worth noting, however, that the predicted probability is still relatively high even for migrants with fully irregular status, indicating a nearuniversality of remitting among Senegalese migrants and an ability to circumvent formal barriers to these transfers. In addition to the negative effect of yearly irregular status, having entered without a visa is also negatively associated with remitting (although only at $p<0.10$ ).

The story for the mixed/semi-irregular statuses is less clear. Compared to having both a residence and work permit (RP_WP), having a residence permit but not a work permit (RP_NWP) is negatively but not significantly associated with remitting, while having a work permit but not a residence permit (NRP_WP) is positively and significantly associated with remitting. Senegalese migrants with only a work permit have a predicted probability of remitting of approximately $85 \%$, making them the group most likely to send money to Senegal. Migrants experience this status quite infrequently (less than $4 \%$ of person-years), however, and most likely as a result of somewhat rare dysfunctions in the receiving states' immigration-control bureaucracies, or simply as the result of poor recall on the part of migrants. The legal reality thus seems to operate as a constraint only on those migrants who lack all forms of authorization instead of those with mixed statuses.

\section{Investing}

Model III of Table 5.2 displays the results from the random-intercept logistic regression of yearly reports of asset ownership in Senegal. These results confirm the negative descriptive association between fully irregular (NRP_NWP) status and investing: Senegalese migrants who lack both a residence permit and a work permit are almost 4 percentage points less likely to own assets in Senegal than those migrants with fully regular (RP_WP) status. Figure 5.6 shows that migrants with fully regular (RP_WP) status have a predicted probability of investing of $8.3 \% ; 50 \%$ lower than probability of investing for migrants with fully irregular status. Contrary to the results for short returns and remitting, however, there is no statistically significant difference between migrants with mixed/semi-irregular statuses and migrants with fully regular status in the probability of investing, nor does visa status at entry have an effect. The constraint of legal status thus blocks or excludes only those migrants with fully irregular status from owning assets in Senegal.

Interestingly, migrants in Italy are significantly less likely than those in France to invest, which is the only destination-specific variation evident in any of the models. This could be related to the preponderance of Mouride migrants in Italy, who may be more likely to donate money to religious endeavors (as is pointed out below, belonging to the Mouride brotherhood is also negatively associated with this outcome). 


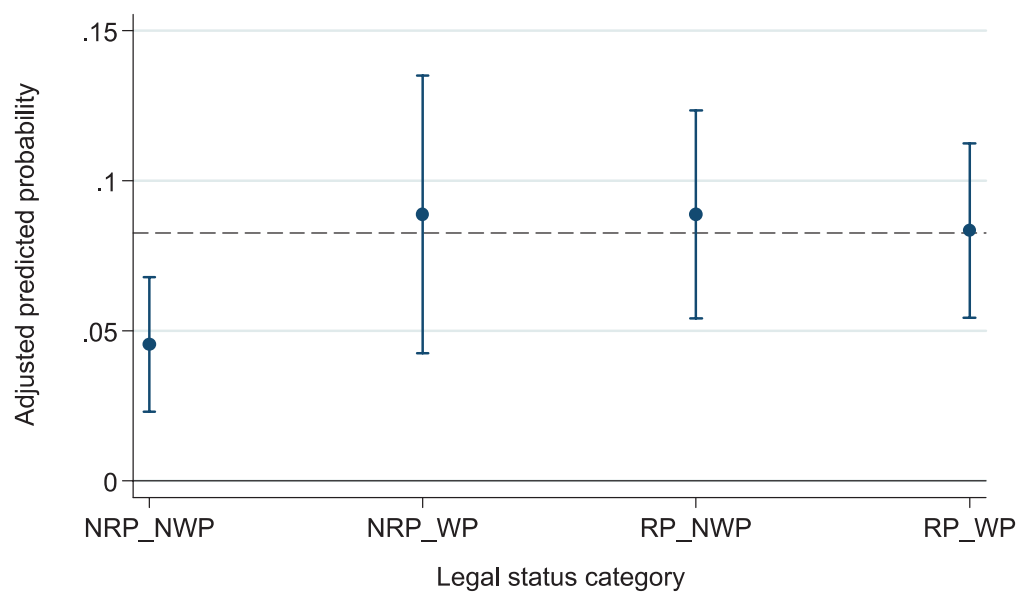

Fig. 5.6 Predicted probability of investing by legal status category, with $95 \%$ confidence intervals (Dashed line represents grand mean of investing)

\section{HTA Participation}

Descriptive statistics indicated that Senegalese migrants with fully irregular legal status are the least likely to make financial contributions to HTAs. Model IV of Table 5.2 supports this finding: migrants who lack both a residence permit and a work permit (NRP_NWP) are less likely than migrants with fully regular status to contribute to such associations. The difference in probabilities between these categories of migrants is small: migrants with fully irregular status are only 0.8 percentage points less likely to participate in these associations than migrants with fully regular status. Nonetheless, as Fig. 5.7 shows, even migrants with fully regular status have a subject-specific predicted probability of HTA participation of only about $2 \%$; migrants with fully irregular status are thus $40 \%$ less likely than migrants with fully regular status to participate in HTAs. Visa status at entry shows no association with HTA participation.

Findings from these multivariate models show that fully irregular legal status is consistently directly associated with a lower probability of engaging in the nonmobile cross-border activities of remitting, investing, and HTA participation among Senegalese migrants, while mixed/semi-irregular statuses do not have a consistent association with these outcomes. There is thus evidence that complete lack of authorization serves as some kind of a legal constraint on these transnational activities. As the activities in and of themselves do not directly depend on the physical crossing of a national border, direct territorial confinement is not an explanation for this negative association. 


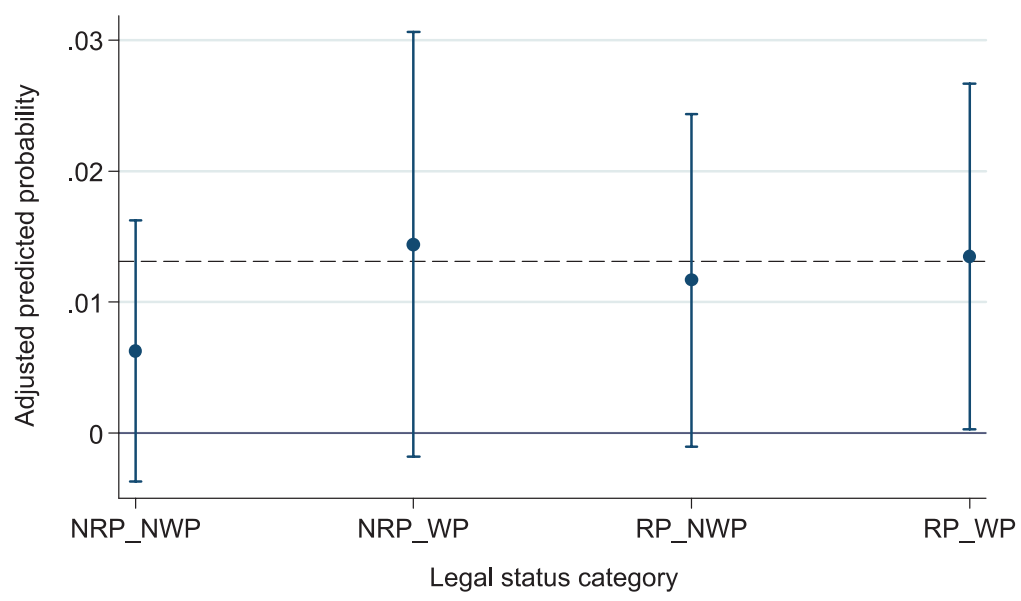

Fig. 5.7 Predicted probability of HTA participation by legal status category (Dashed line represents grand mean of HTA participation)

Just as lack of legal status prevents the legal crossing of borders, though, lack of legal status could prevent migrants from crossing other institutional boundaries that might be important for transnational engagement. Having fully irregular status might make migrants less likely to use formal financial services, which could limit their abilities to accumulate money and capital to repatriate as remittances or investments; they might also have fewer options for the actual transfer of funds or for accessing credit. Although it is clear that employment and good self-reported economic status are positively associated with these outcomes, these effects are net of the negative association with fully irregular status and thus do not mediate this effect.

Furthermore, Chap. 4 has shown that lack of legal status does not negatively affect male Senegalese migrants' probability of employment in these three countries; while employment per se is not limited by irregular status, irregularity may constrain Senegalese migrants' ability to participate in the formal labor market, thus increasing these migrants' precariousness. Older migrants with more time in the destination country also tend to be more likely to participate in these non-mobile transnational activities, and these are the very migrants who tend to possess a moresecure legal status. While it is clear that migrants with fully irregular status may be excluded from some institutions which may in turn facilitate cross-border action, their transnational activities may also be blocked by the uncertainty and precariousness that accompanies their lack of secure legal status. There is thus evidence that the legal reality constrains the transnational action of migrants with fully irregular status, but the mechanism of this legal constraint is still somewhat unclear. 


\section{Hypothesis 3: Maintenance of Affective Ties}

\section{Direct Effect of Short Returns on Non-mobile Transnational Activities}

The third hypothesis of this chapter is that visits to the homeland will promote other forms of non-mobile transnational activities through the maintenance of affective ties and the ability to gather first-hand information. The models for remitting, investing, and HTA participation thus include yearly short returns as a predictor, allowing examination of the direct effect of a visit home on these non-mobile activities. Models II, III, and IV in Table 5.2 display the direct effects of short visits to the homeland in the same year on each of the non-mobile outcomes. Returning to Senegal for a visit is associated with an increase of almost 6 percentage points in the probability of remitting and almost 2 percentage points in the probability of reporting asset ownership in Senegal. There is a positive association between short returns and participating in HTAs, but the effect is not statistically significant. These AMEs are displayed graphically in Fig. 5.8.

For two of the three non-mobile transnational activities, then, there is a positive direct relationship between visiting home and the probability of cross-border action. Both remitting and investing are financial decisions that migrants make in conjunction with their families: migrants decide whether to send money to family in Senegal or to invest capital in assets in Senegal in response to personal and collective desires. While other factors may influence these decisions (as we will examine below), they are fundamentally about allocation of resources in an extended family unit and are thus responsive to bonds of trust and emotion with the receivers of those resources.

Financial decisions are thus subject to first-hand ties and the ability to gather information: short visits to Senegal thus allow migrants to strengthen social ties and

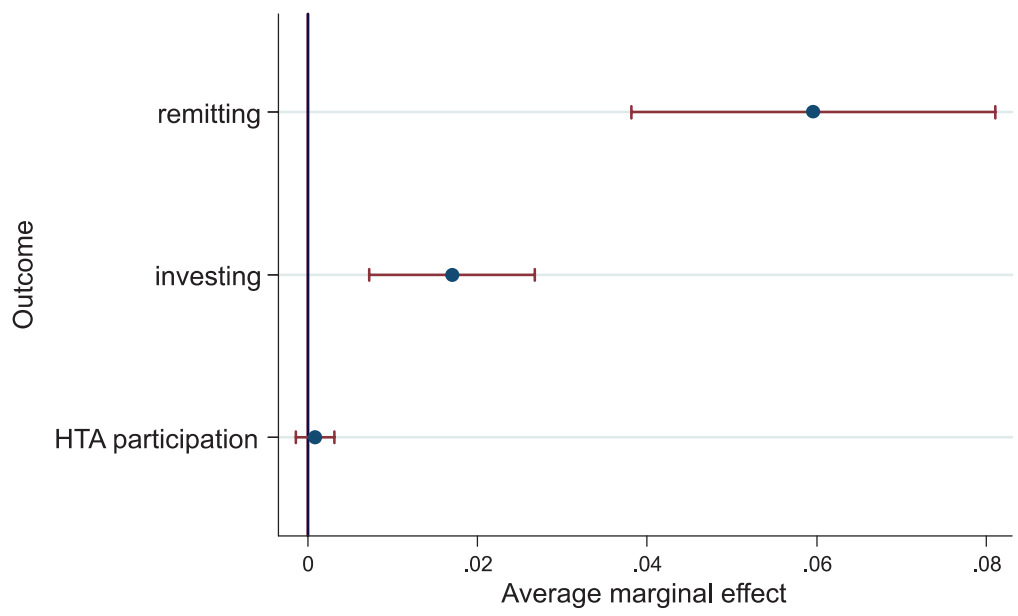

Fig. 5.8 Average marginal effects of short returns, by outcome, with $95 \%$ confidence intervals. (Source: MAFE-Senegal. Effects for short returns are net of other variables on each model) 
gather information about investment opportunities via physical presence. These visits may also allow the family at origin to more effectively extract resources from the migrant, as the contract-centered literature on remittances (Chort et al. 2012) might suggest. The same cannot be said about participation in HTAs, wherein a migrant makes a decision to participate financially but the association makes a collective decision about how to allocate those funds. This allocation decision is thus less sensitive to individual, personal visits to the homeland and the affective and socialtie-reinforcing co-presence that such visits produce.

\section{Direct Effect of Other Affective Ties (Spouse, Children, Other Family Ties)}

Other variables in the multivariate models (see Table 5.2) also demonstrate the importance of maintaining social and informational ties for both visits to the homeland and the non-mobile transnational activities. Having a spouse in Senegal is highly predictive of traveling there for a visit: such migrants are 15 percentage points more likely than migrants without a spouse in Senegal to travel there. Other kinds of family ties, however, were not predictive of increased mobility: migrants with children in Senegal showed no statistically significant difference in the likelihood of a short visit, while migrants with at least one parent alive in Senegal were actually 5.3 percentage points less likely than migrants without still-living parents to make a trip back. Family ties to individuals residing in Senegal are predictive of increased individual non-mobile transnational engagements. Senegalese migrants with a child in Senegal are 7.2 percentage points more likely to remit and 2.9 percentage points more likely to report owning assets in Senegal.

Having a spouse residing in Senegal was similarly positively associated with higher non-mobile transnational engagement: Senegalese migrants with a spouse in the homeland are 3.8 percentage points more likely to remit (although at $p<0.1$ ), and 2 percentage points more likely to own assets. In addition, having at least one parent alive in Senegal is associated with a 12-percentage-point increase in the probability of remitting. Active social ties to family in Senegal clearly promote individual economic non-mobile transnational activities.

In a by-now familiar pattern, HTA participation responds differently to these indicators of affective ties. Neither spouse nor living parent in Senegal has a significant association with HTA participation, while having a child in Senegal is negatively associated with participation in associations. Neither occasional physical co-presence in Senegal nor the residence of family members in Senegal is associated with collective cross-border activities. These results thus support the hypothesis that affective links with family members residing in the homeland encourage cross-border social action, but once again only for those financial activities that are responsive to these kinds of personal affective ties. 


\section{Direct Effect of Other Circulation-Related Variables}

Other variables also indicate the importance of circulating between destination and origin for ongoing non-mobile cross-border engagement. The number of trips is highly predictive of transnational activities: each additional prior trip is associated with a 7.2 percentage-point increase in the probability of remitting, a 5.2 percentagepoint increase in the probability of investing, and an almost 1 percentage-point increase in the probability of HTA participation. Repeat migration (approximately $30 \%$ of the sample reported more than one trip) thus reinforces the transnational social field in such a way as to make non-mobile transnational action more likely for both individual and collective activities.

Other indicators of a circular migration strategy are also related to remitting and investing. Migrants who reported planning to stay definitively in the destination country ( $46 \%$ of the sample) are 10 percentage points less likely to remit than those who do not plan to stay definitively, indicating that remitting is integral to Senegalese migrants' ability prepare an eventual return to Senegal. Migrants who reported having migrated principally for work or in search of a better life are 14 percentage points more likely to remit and 5.4 percentage points more likely to own assets in Senegal, suggesting that those migrants with a logic of accumulation are more likely to participate in these forms of financial cross-border action.

\section{Hypothesis 4: Caging and Indirect Effects of Legal Status Via Short Returns}

Results from the decomposition of direct effects indicate a significant negative indirect effect of fully irregular status on remitting and investing via the mediator of reduced short returns. While Table 5.2 displays the negative direct effects of irregular legal statuses and the positive direct effects of visits to the homeland on nonmobile transnational activities of Senegalese migrants, these models do not allow testing of the hypothesis of an indirect effect of irregular statuses on non-mobile activities via territorial confinement (see Fig. 5.1 for the theoretical model). Table 5.3 presents results from the non-linear decomposition of total effects using the KHB method and shows the direct, indirect, and total effects ${ }^{5}$ of irregular legal statuses on the non-mobile transnational activities of remitting, investing, and HTA participation.

Indirect effects of each of these statuses on the non-mobile activities run through the mediator of short returns. For remitting and investing, the indirect effect of fully irregular status (NRP_NWP) is negative and significant: 14\% of the total negative

\footnotetext{
${ }^{5}$ The effects are presented as logit coefficients (log-odds) so are not directly comparable to the quantities in Table 5.2. The direction and significance of the direct effects of legal status on each non-mobile transnational activity are the same as those presented in Table 5.2: there is a negative direct effect of fully irregular status on all three non-mobile activities, and a non-significant direct effect of the semi-irregular statuses on investing and HTA participation.
} 


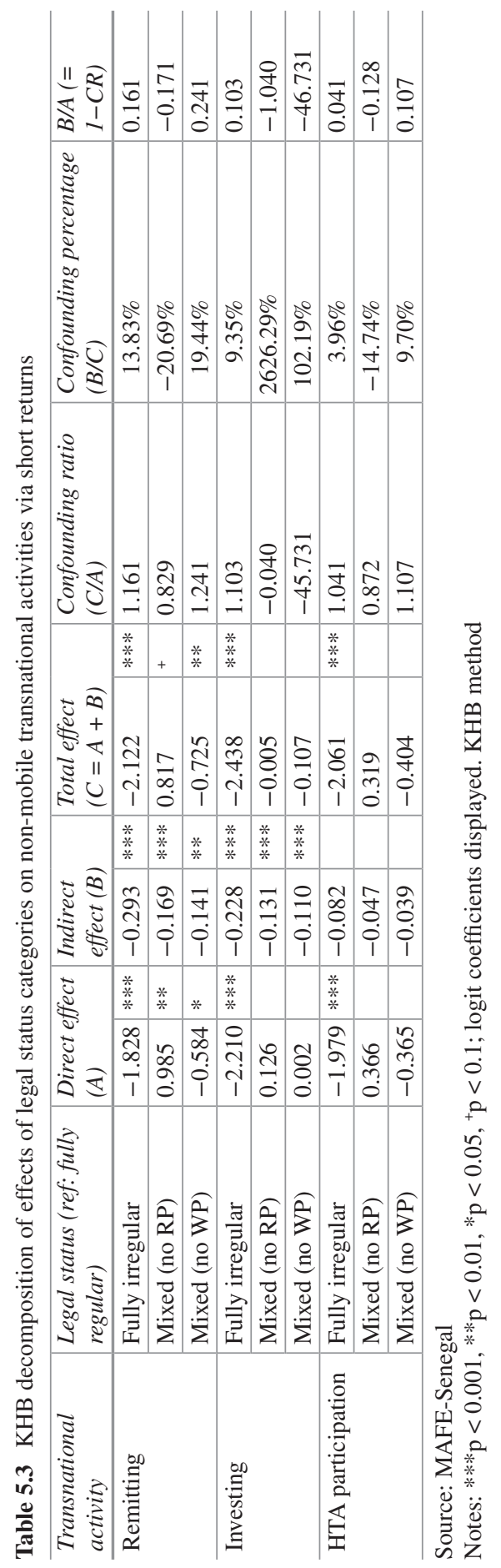


effect of legal status on remitting is due to short returns, while short visits to the homeland account for $9 \%$ of the total negative effect of legal status on investing. Thus, migrants with fully irregular (NRP_NWP) face not only a direct legal constraint from their irregular status but also an indirect negative constraint of their status via short returns: their irregular status directly reduces their ability to travel between destination and origin, and such visits encourage transnational engagement. The lack of ability to maintain and reinforce these social ties translates into reduced cross-border action. Irregular status serves to confine migrants to the territory of the destination, and thus cages their non-mobile transnational activities.

The pattern of indirect effects for the two mixed statuses reinforces the notion that territorial confinement is an indirect legal constraint even on individual nonmobile transnational activities. While the direct effects of these two semi-irregular statuses on remitting and investing is somewhat complicated, the pattern of indirect effects is unambiguously negative, indicating that the direct negative legal constraint of these mixed statuses on the ability to visit the homeland indirectly reduces the remitting and investing of Senegalese migrants who lack either a residence permit or a work permit.

The KHB method thus finds evidence to support the hypothesis of an indirect effect of territorial confinement on remitting and investing. The KHB method fails to find an indirect effect of fully irregular (NRP_NWP) or mixed statuses on HTA participation, which confirms the interpretation that this kind of collective cross-border activity is less sensitive to the maintenance of affective links afforded by in-person visits.

\subsection{Discussion}

Despite a celebration of the border-subverting nature of transnational activities, research on the role of the state suggests that the crossing of both geographic (Waldinger 2008) and institutional (Van Meeteren 2012) borders by migrants is subject to state control. One of the most pertinent forms of control for these types of border crossings is legal status: migrants who do not possess a secure form of legal status will find it more difficult to come and go physically across the destination state's borders and may also find it challenging to access other institutions that require formal state recognition and may help support cross-border engagement.

The results of this chapter unambiguously support the territorial confinement hypothesis: Senegalese migrants with fully irregular or mixed statuses were significantly less likely to make short returns to the homeland. These insecure legal statuses thus impose a direct constraint on Senegalese migrants' physical mobility. In Waldinger's (2008) territorial-confinement formulation, they are at the mercy of state immigration-control mechanisms for their ability to make trips back to the homeland. This finding is at odds with the portrayal of a globalized world in which movements are unfettered by borders, but is consistent with other research on globalization that sees some flows - capital, goods, and some kinds of workers-as 
freer than others-such as migrant labor (for the example of asymmetric flows in the NAFTA regime, see Massey et al. 2002).

The results of this chapter also support the hypothesis that migrants' transnational activities can be blocked by their lack of secure legal status and the exclusion from other formal institutions that ensues. Fully irregular status operated as a direct constraint on remitting, investing, and HTA participation for Senegalese migrants. It seems that this status may exclude these migrants from accessing other formal institutions that are, in some way, related to cross-border engagement. Lack of ability to open a bank account or apply for credit, both of which require documentation, might constrain migrants' transnational activities. While irregular status does not prevent Senegalese migrants from working, it certainly prevents them from working in the formal labor market and probably relegates them to insecure and poorly remunerated employment; this precarity that accompanies exclusion from the formal sector and its guarantees might decrease the ability and motivation to participate in transnational activities. These findings seem to be at odds with other literature on transnationalism that argues that cross-border action can be the result of exclusion and discrimination felt by migrants at destination (Itzigsohn and Saucedo 2002; Sana 2005); in the case of Senegalese migrants, the structural exclusion that accompanies irregularity of legal status seems to outweigh the reactive impulse.

Indeed, the results of these models indicate that Senegalese migrants may depend in some ways on the accumulation of resources for successful transnational engagement, at least for the individual financial activities of remitting and investing. Migrants who report being employed are 46 percentage-points more likely to report remitting in a given year than migrants who are unemployed, while reporting work/ search for a better life as the main motivation for having migrated is associated with a 14 percentage-point increase in the yearly probability of remitting. Migrants with good self-reported economic status are 6 percentage points more likely to own assets in Senegal, while those who report work or a better life as the motivation for their migration are 5.4 percentage points more likely to be investors.

This strategy of accumulation can be interpreted in light of the strong effects of short visits to the homeland and the affective ties that these visits foster. Making a visit to the homeland was associated with increased propensity to remit and invest: this form of mobility is thus of crucial importance in explaining these financial forms of non-mobile transnational activities. This is unsurprising given the assertions of the literature of physical co-presence, which has demonstrated that face-toface interaction is crucial in forging and feeding social ties and interpersonal trust (Urry 2002), but this is important determinant of action at a distance has been ignored in studies of transnational activities.

The direct effects of affective ties and other links to the homeland are also clear in the models: having children, a spouse, or parents in Senegal are associated with individual non-mobile transnational activities, as is repeat migration. All of these predictors indicate that ongoing links to the homeland are of paramount importance in structuring transnational engagement among Senegalese migrants. These findings thus reinforce the idea that building social status in Senegal in preparation for an eventual return is a principal motivation of Senegalese migrants (Kaag 2008; 
Kane 2011; Riccio 2008); Senegalese migrants may thus favor accumulation of resources as a way to finance their transnational engagement, perhaps even at the expense of pursuing integration in the destination society (Kaag 2008; van Nieuwenhuyze 2008).

In addition to examining the direct effect of visits to the homeland on longdistance transnational activities, this chapter found an indirect, negative effect of irregular legal statuses on these non-mobile activities transmitted through the inability to circulate between destination and origin. Migrants who have irregular status thus face three kinds of legal constraints on their cross-border actions: a direct legal constraint on their physical mobility, limiting short returns to Senegal; a direct legal constraint on their formal institutional participation, limiting their remitting, investing, and HTA participation; and an indirect legal constraint on their remitting and investing through their inability to visit home and the concomitant curtailing of social ties. Previous studies of transnational activities, in neglecting the relationship between visits home and non-mobile transnational activities, have thus neglected an important mechanism for the constraint that legal status may have on cross-border action.

The results of this chapter have also shown that not all transnational activities are subject to the same legal and social determinants. While fully irregular legal status was negatively directly associated with all four transnational activities, there were important differences among the other predictors. Semi-irregular legal statuses had a strong negative association with short returns, indicating that mobility is closely related to security of legal status. In turn, short returns along with variables indicating ongoing social and affective ties to Senegal were important predictors of both remitting and investing, both individual financial decisions likely to be influenced by sentiment and trust. This strong positive direct association was translated into a negative indirect association with semi-irregular status for these two financial activities through the constraint on border crossing, showing them to be sensitive to legal limitations on physical mobility.

HTA participation, on the other hand, is a collective activity and, as such, seems to be less responsive to physical co-presence in Senegal and affective ties to the homeland. Indeed, if there is any evidence of reactive transnationalism (Itzigsohn and Saucedo 2002), it may be with participation in these associations, as those migrants who do not speak the language of their destination are almost 6 percentage points more likely to report such participation. Legal exclusion does not motivate such reaction, but the HTA variable may not actually capture the full range of forms of participation in these associations as it only asks about financial contributions to them and not benefits from the social services to migrants in destination that such associations often provide. This study has thus shown that it is necessary to distinguish, in the Senegalese case, between affectively oriented and collective transnational activities, echoing Waldinger's (2008) assertion that transnational activities do not necessarily cluster together.

From a methodological perspective, the results of this chapter underline the importance of disaggregating traditional binary measures of legal status. For all of the transnational outcomes, there were differences between migrants with fully 
irregular status and those with mixed statuses that would have been erased by lumping them together as "irregular." Indeed, research has shown the empirical and conceptual value of a distinction between semi-compliant mixed statuses and fully irregular status (Ruhs and Anderson 2010), which this chapter's results underscore. At the same time, migrants' legal status upon entry, as measured by having a visa, had no association with transnational activities. Irregularity is thus complex, as Chap. 3 demonstrated, and this complexity needs to be taken into account when considering the constraints that this multifaceted legal reality places on migrants' actions.

\subsection{Conclusion}

Modern nation-states place contradictory demands on migrant's cross-border activities. On the one hand, many destination-country governments have started to recognize the role that migrants can and do play in the development of their homelands and have put in place "co-development" schemes (Kabbanji 2013; Weil 2002) to leverage transnational activities for the benefit of development programs. On the other hand, states have erected increasingly restrictive immigration-control apparatuses that make it difficult to acquire secure legal status. This difficulty translates into a captured loyalty among legal migrants, who have invested heavily in their membership, and a physical territorial confinement of those migrants who lack regular status. This control apparatus, coupled with a dominant ideology of assimilation that often looks askance at foreign loyalties, thus implicitly limits the cross-border activities of both documented and undocumented migrants.

The research literature on transnational activities has not grappled with these contradictions. Research on transnationalism has debated the novelty and social configurations of cross-border activities, but most studies do not consider the role that legal status plays in promoting or constraining them. This chapter suggests that territorial confinement, which results from lack of secure legal status produced by restrictive immigration-control apparatuses, not only directly constrains mobile transnational activities such as homeland visits but also indirectly reduces migrants' participation in non-mobile activities, such as remitting and investing. This chapter hypothesizes that the indirect relationship is mediated by short visits home, which nourish the affective social infrastructure that facilitates ongoing non-mobile, longdistance cross-border activities.

This chapter finds that legal status is an important predictor of transnational engagement, especially when the direct legal constraint on physical mobility is factored into other non-mobile forms of cross-border action. At the same time, the robustness of the social and affective infrastructure of most transnational activities indicates that legal status may constrain but does not completely determine crossborder action. While the state and formal institutions may demand "papers" for the crossing of some kinds of borders, migrants clearly find ways to circumvent these demands; this chapter shows that even migrants completely bereft of residence and 
work authorization have a non-zero probability of crossing the destination state's geographical border for a short visit to Senegal and continue to engage in other transnational activities. Indeed, research has shown that some Senegalese migrants may use non-mobile transnational activities such as remitting as a way to maintain affective ties with family in Senegal even without physical visits to the homeland (Hannaford 2016). At the same time, this chapter shows the importance of taking legal status into account as transnational activities are clearly subject to a number of legal constraints. This chapter demonstrates that it is crucial to consider multiple kinds of statuses: an approach that collapsed fully and semi-irregular statuses would have obscured the robust negative association between fully irregular status and all kinds of transnational activities.

The results of this chapter also allow a re-examination of the concept of a Senegalese "mode of migration" that is centered around "transnational livelihoods" (Riccio 2001, 2008). Qualitative literature has suggested that Senegalese migrants engage in an explicitly transnational form of migration, with Mouride traders in Italy depicted as the most likely to live their lives in Senegal and in Europe simultaneously. The ability to circulate between destination and origin is of key importance in this strategy, as it allows migrants to conduct entrepreneurial business across borders. This chapter, however, finds no effect of belonging to the Mouride brotherhood or of being self-employed in trading on the propensity of migrants to make short visits to Senegal net of legal status, affective ties, and the model's other variables. Indeed, belonging to the Mouride brotherhood is negatively associated with owning assets in Senegal, and being self-employed in trading is negatively associated with both remitting and investing. Living in Italy is likewise not associated with a transnational livelihood, and moreover had a negative effect on investing. Thus, a transnational lifestyle among Senegalese seems less associated with the cultural dispositions of certain religious and ethnic subgroups and more related to the interplay between the legal institutional structure that acts to constrain crossborder action and social infrastructure that drives these activities.

This study does lend credence, however, to the idea that the "homeland is the arena" (Kane 2011) in which social status matters for Senegalese migrants. There are strong effects of short visits, social ties, repeat migration, plans to return, and work-related motivation on non-mobile transnational activities. This shows that Senegalese migrants' cross-border engagement is largely motivated by a desire to return to Senegal eventually. A logic of accumulation at origin may thus dominate a logic of integration at destination (van Nieuwenhuyze 2008); both of these logics, however, are blocked by lack of secure legal status: migrants without "papers" are both directly blocked from transnational participation via legal exclusion from border crossing, and indirectly blocked by physical caging in the destination and the concomitant withering of social ties. Legal status is thus of key importance in keeping open the door to the homeland. 


\section{Appendices}

\section{Appendix A: Wording of Questions on Transnational Activities in MAFE-Senegal Questionnaire}

\begin{tabular}{l|l}
\hline $\begin{array}{l}\text { Transnational } \\
\text { activity }\end{array}$ & Question \\
\hline Short returns & $\begin{array}{l}\text { When you lived in [destination country], did you return to Senegal for a duration } \\
\text { of less than one year? In which year(s) did you return? }\end{array}$ \\
\hline Remittances & $\begin{array}{l}\text { Have there been periods of your life during which you regularly sent money to } \\
\text { someone who was in a country other than the one in which you lived? From } \\
\text { which year(s) to which year(s)? And in which country(ies) did the individual(s) } \\
\text { to whom you sent money live? }\end{array}$ \\
\hline Investments & $\begin{array}{l}\text { Now we will talk about the assets or businesses that you may have bought over } \\
\text { your lifetime, or that you may have received or inherited from somebody. Are } \\
\text { you CURRENTLY owner, in Senegal or elsewhere, of one or several plots of } \\
\text { land (agricultural land, building plot, or under construction); of one or several } \\
\text { house units (house, apartment...); of a business, venture, commercial premises } \\
\text { even on a rental basis (shop, workshop, taxis...)? And IN THE PAST, have you } \\
\text { been owner, in Senegal or elsewhere, of plots that you don't own anymore; of } \\
\text { house units that you don't own anymore; of a business, a venture, commercial } \\
\text { premises even on a rental basis that you don't own anymore? [then, for each } \\
\text { asset] in which country is this asset located? And how did you obtain this asset? }\end{array}$ \\
\hline Associations & $\begin{array}{l}\text { In the time that you spent abroad, were you at any time paying contributions or } \\
\text { membership fees to one or more associations (including religious organisations) } \\
\text { that finance projects in Senegal or support Senegalese migrants in Europe? From } \\
\text { which year(s) to which year(s)? }\end{array}$ \\
\hline
\end{tabular}

Source: MAFE-Senegal biographical questionnaire

\section{Appendix B: Raw Coefficient Estimates for Models from this Chapter}

\begin{tabular}{|c|c|c|c|c|}
\hline \multirow[b]{3}{*}{ Predictor } & \multicolumn{4}{|l|}{ Outcome } \\
\hline & $\begin{array}{l}\text { I. Short } \\
\text { returns }\end{array}$ & II. Remitting & III. Investing & \begin{tabular}{|l|} 
IV. HTA \\
participation
\end{tabular} \\
\hline & $\mathrm{B}(\mathrm{se})$ & $\mathrm{B}(\mathrm{se})$ & $\mathrm{B}(\mathrm{se})$ & $\mathrm{B}(\mathrm{se})$ \\
\hline Short return (ref.: none) & - & $0.90 * * *(5.52)$ & $0.67 * * *(4.00)$ & $0.16(0.77)$ \\
\hline \multicolumn{5}{|l|}{$\begin{array}{l}\text { Legal status (ref: fully } \\
\text { regular: RP_WP) }\end{array}$} \\
\hline $\begin{array}{l}\text { Fully } \\
\text { irregular (NRP_NWP) }\end{array}$ & $\begin{array}{l}-2.53 * * * \\
(-13.02)\end{array}$ & $\begin{array}{l}-1.39 * * * \\
(-5.53)\end{array}$ & $\begin{array}{l}-1.91 * * * \\
(-4.33)\end{array}$ & $\begin{array}{l}-2.04 * * * \\
(-4.33)\end{array}$ \\
\hline Mixed (NRP_WP) & $\begin{array}{l}-1.05 * * * \\
(-3.93)\end{array}$ & $0.96 *(2.01)$ & $0.21(0.30)$ & $0.17(0.21)$ \\
\hline Mixed (RP_NWP) & $\begin{array}{l}-0.52 * * \\
(-3.10)\end{array}$ & $-0.43(-1.58)$ & $0.20(0.58)$ & $-0.37(-0.90)$ \\
\hline
\end{tabular}




\begin{tabular}{|c|c|c|c|c|}
\hline \multirow[b]{3}{*}{ Predictor } & \multicolumn{4}{|l|}{ Outcome } \\
\hline & $\begin{array}{l}\text { I. Short } \\
\text { returns }\end{array}$ & II. Remitting & III. Investing & $\begin{array}{l}\text { IV. HTA } \\
\text { participation }\end{array}$ \\
\hline & B (se) & $\mathrm{B}(\mathrm{se})$ & B (se) & B (se) \\
\hline \multicolumn{5}{|l|}{ Destination (ref: France) } \\
\hline Spain & $0.06(0.24)$ & $0.17(0.28)$ & $-0.71(-0.91)$ & $-1.34(-1.06)$ \\
\hline Italy & $\begin{array}{l}-0.29 \\
(-1.11)\end{array}$ & $-0.51(-0.77)$ & $\begin{array}{l}-1.97 * * \\
(-3.05)\end{array}$ & $-2.97 * *(-2.58)$ \\
\hline $\begin{array}{l}\text { Entry status: no visa (ref: } \\
\text { visa) }\end{array}$ & \begin{tabular}{|l|}
-0.07 \\
$(-0.51)$
\end{tabular} & $-0.49^{+}(-1.72)$ & $0.36(0.83)$ & $0.22(0.46)$ \\
\hline Years in destination & \begin{tabular}{|l}
$0.15 * * *$ \\
$(8.55)$ \\
\end{tabular} & $\begin{array}{l}0.46^{* * * *} \\
(14.23)\end{array}$ & $\begin{array}{l}0.58 * * * \\
(14.11)\end{array}$ & $0.41 * * *(8.06)$ \\
\hline $\begin{array}{l}\text { Years in destination } \\
\text { squared }\end{array}$ & $\begin{array}{l}-0.00 * * * \\
(-6.95)\end{array}$ & $\begin{array}{l}-0.01 * * * \\
(-11.98)\end{array}$ & $\begin{array}{l}-0.01 * * * \\
(-7.86)\end{array}$ & $\begin{array}{l}-0.01 * * * \\
(-3.53)\end{array}$ \\
\hline $\begin{array}{l}\text { Period of arrival: post-1990 } \\
\text { (ref: pre-1990) }\end{array}$ & $0.23(1.06)$ & $-0.21(-0.38)$ & $0.37(0.54)$ & $-1.39(-1.50)$ \\
\hline $\begin{array}{l}\text { Age at start of current } \\
\text { migration spell }\end{array}$ & $\begin{array}{l}-0.00 \\
(-0.15)\end{array}$ & $0.04(1.08)$ & $0.16 * *(3.21)$ & $0.23 * * *(4.00)$ \\
\hline Sex: Male (ref: female) & $0.07(0.33)$ & $-0.43(-0.73)$ & $1.06(1.18)$ & $2.55 *(2.31)$ \\
\hline Years of education & $0.04 *(2.28)$ & $-0.10^{+}(-1.90)$ & $0.08(1.12)$ & $0.17^{+}(1.93)$ \\
\hline $\begin{array}{l}\text { Ethnicity: Wolof (ref.: } \\
\text { other) }\end{array}$ & $0.24(1.18)$ & $0.12(0.22)$ & $1.02(1.16)$ & $-1.88^{+}(-1.73)$ \\
\hline $\begin{array}{l}\text { Religion: Mouride (ref.: } \\
\text { other) }\end{array}$ & $0.33(1.51)$ & $0.03(0.05)$ & $-1.62^{+}(-1.74)$ & $-3.96 * *(-3.28)$ \\
\hline \multicolumn{5}{|l|}{$\begin{array}{l}\text { Economic activity (ref.: } \\
\text { unemployed) }\end{array}$} \\
\hline Employed & $0.27(1.09)$ & $\begin{array}{l}4.25 * * * \\
(10.28)\end{array}$ & $-0.76(-1.58)$ & $3.58 * * *(4.47)$ \\
\hline Inactive & $0.02(0.08)$ & $0.81^{+}(1.78)$ & $-0.84(-1.47)$ & $3.34 * * *(3.85)$ \\
\hline $\begin{array}{l}\text { Occupation: self-employed } \\
\text { (ref.: other) }\end{array}$ & $\begin{array}{l}-0.13 \\
(-0.72)\end{array}$ & $-0.67^{+}(-1.87)$ & $\begin{array}{l}-1.10^{* *} \\
(-2.58)\end{array}$ & $-0.38(-0.65)$ \\
\hline $\begin{array}{l}\text { Self-reported econ. status: } \\
\text { good (ref.: bad) }\end{array}$ & $0.28(1.20)$ & $-0.37(-0.79)$ & $1.96 * * *(3.38)$ & $-0.47(-0.54)$ \\
\hline $\begin{array}{l}\text { Number of contacts at } \\
\text { destination }\end{array}$ & $0.01(0.27)$ & $\begin{array}{l}-0.11^{*} \\
(-1.97)\end{array}$ & $0.43 * * *(4.91)$ & $0.19 *(2.15)$ \\
\hline Number of trips & $0.06(0.74)$ & $1.03 * * *(4.24)$ & $2.06 * * *(5.74)$ & $1.64 * * *(3.35)$ \\
\hline $\begin{array}{l}\text { Does not speak language of } \\
\text { destination }\end{array}$ & $\begin{array}{l}-0.16 \\
(-0.76)\end{array}$ & $1.22 *(2.30)$ & $-0.67(-0.94)$ & $6.50 * * *(6.42)$ \\
\hline Kids in Senegal (ref.: no) & $\begin{array}{l}-0.01 \\
(-0.09) \\
\end{array}$ & $1.07 * * *(3.65)$ & $1.09 * * *(3.35)$ & $-1.46 * *(-3.21)$ \\
\hline $\begin{array}{l}\text { Spouse in Senegal (ref.: } \\
\text { no) }\end{array}$ & \begin{tabular}{|l|}
$1.02 * * *$ \\
$(6.34)$
\end{tabular} & $0.56^{+}(1.82)$ & $0.78 *(2.34)$ & $0.98 *(2.21)$ \\
\hline $\begin{array}{l}\text { Geographic origin: from } \\
\text { Dakar (ref.: other) }\end{array}$ & $0.15(0.74)$ & $-0.53(-0.98)$ & $\begin{array}{l}-3.70 * * \\
(-3.29)\end{array}$ & $-3.70 * *(-3.29)$ \\
\hline
\end{tabular}




\begin{tabular}{|c|c|c|c|c|}
\hline \multirow[b]{3}{*}{ Predictor } & \multicolumn{4}{|l|}{ Outcome } \\
\hline & $\begin{array}{l}\text { I. Short } \\
\text { returns }\end{array}$ & II. Remitting & III. Investing & \begin{tabular}{|l|} 
IV. HTA \\
participation
\end{tabular} \\
\hline & B (se) & B (se) & B (se) & B (se) \\
\hline $\begin{array}{l}\text { Father's ed.: < secondary } \\
\text { school (ref.: more) }\end{array}$ & $\begin{array}{l}-0.12 \\
(-0.56) \\
\end{array}$ & $-0.95^{+}(-1.67)$ & $0.15(0.17)$ & $-1.28(-1.18)$ \\
\hline $\begin{array}{l}\text { Trip paid by family (ref.: } \\
\text { no) }\end{array}$ & $\begin{array}{l}-0.09 \\
(-0.46)\end{array}$ & $-0.07(-0.14)$ & $0.19(0.29)$ & $1.75^{+}(1.94)$ \\
\hline $\begin{array}{l}\text { Plan to stay: definitive } \\
\text { (ref.: no) }\end{array}$ & $\begin{array}{l}-0.07 \\
(-0.40)\end{array}$ & $\begin{array}{l}-1.41 * * \\
(-3.04)\end{array}$ & $-0.54(-0.90)$ & $-1.33(-1.49)$ \\
\hline $\begin{array}{l}\text { Trip motivation: work/ } \\
\text { better life (ref.: other) }\end{array}$ & $\begin{array}{l}-0.03 \\
(-0.17)\end{array}$ & $1.87 * * *(4.37)$ & $2.23 * * *(3.46)$ & $0.85(1.19)$ \\
\hline $\begin{array}{l}\text { At least one parent alive in } \\
\text { Snl (ref.: no) }\end{array}$ & $\begin{array}{l}-0.36^{*} \\
(-2.50)\end{array}$ & $1.61 * * *(5.60)$ & $-0.31(-0.90)$ & $0.09(0.21)$ \\
\hline Constant & $\begin{array}{l}-2.92 * * * \\
(-4.80)\end{array}$ & $\begin{array}{l}-5.76 * * * \\
(-4.13)\end{array}$ & $\begin{array}{l}-21.15 * * * \\
(-9.78)\end{array}$ & $\begin{array}{l}-28.40 * * * \\
(-10.55)\end{array}$ \\
\hline Observations & 8119 & 8119 & 8119 & 8119 \\
\hline AIC & 6884.76 & 3941.22 & 2066.6 & \begin{tabular}{|l|}
3080.79 \\
\end{tabular} \\
\hline $\mathrm{BIC}$ & 7101.82 & 4156.28 & 2290.66 & 3304.85 \\
\hline Log likelihood & -3411.38 & -1938.61 & -1001.3 & -1508.39 \\
\hline$\chi^{2}$ & 493.55 & 637.36 & 567.16 & 305.85 \\
\hline Degrees of freedom & 29 & 30 & 30 & 30 \\
\hline$\rho$ & 0.51 & 0.90 & 0.94 & 0.97 \\
\hline$\sigma_{U}$ & 1.86 & 5.52 & 7.25 & 10.91 \\
\hline
\end{tabular}

Source: MAFE-Senegal. t statistics in parentheses. ${ }^{+} \mathrm{p}<0.10,{ }^{*} \mathrm{p}<0.05,{ }^{*} \mathrm{p}<0.01, * * * \mathrm{p}<0.001$. Random-intercept logistic regression coefficients

\section{References}

Beauchemin, C., Caarls, K., \& Mazzucato, V. (2013). Senegalese migrants between here and there: An overview of family patterns. MAFE Working Papers (MAFE Working Paper 33). Paris: INED.

Bloch, A. (2008). Zimbabweans in Britain: Transnational activities and capabilities. Journal of Ethnic \& Migration Studies, 34(2), 287-305.

Boccagni, P. (2012a). Rethinking transnational studies: Transnational ties and the transnationalism of everyday life. European Journal of Social Theory, 15(1), 117-132.

Boccagni, P. (2012b). Revisiting the 'transnational' in migration studies: A sociological understanding. Revue Européenne Des Migrations Internationales, 28(1), 33-50.

Cameron, A. C., \& Trivedi, P. K. (2010). Microeconometrics using stata (Revised ed.). College Station: StataCorp LP.

Carling, J. (2007). Migration control and migrant fatalities at the Spanish-African borders. The International Migration Review, 41(2), 316.

Chort, I., Gubert, F., \& Senne, J.-N. (2012). Migrant networks as a basis for social control: Remittance incentives among Senegalese in France and Italy. Regional Science and Urban Economics, 42(5), 858-874.

Cisse, F. (2011). Senegal. In S. Mohapatra \& D. Ratha (Eds.), Remittance markets in Africa. Washington, D.C.: World Bank Publications. 
Diminescu, D. (2008). The connected migrant: An epistemological manifesto. Social Science Information, 47(4), 565-579.

Diop, M. (1993). L'immigration Ouest-Africaine En Europe. Études Internationales, 24(1), $111-124$.

Foner, N. (1997). What's new about transnationalism?: New York immigrants today and at the turn of the century. Diaspora: A Journal of Transnational Studies, 6(3), 355-375.

Freeman, G. P. (1995). Modes of immigration politics in liberal democratic states. International Migration Review, 29(4), 881-902.

Grillo, R., \& Riccio, B. (2004). Translocal development: Italy-Senegal. Population, Space and Place, 10(2), 99-111.

Guarnizo, L. E. (2003). The economics of transnational living. International Migration Review, 37(3), 666-699.

Guarnizo, L. E., Portes, A., \& Haller, W. (2003). Assimilation and transnationalism: Determinants of transnational political action among contemporary migrants. American Journal of Sociology, 108(6), 1211-1248.

Hannaford, D. (2016). Intimate remittances: Marriage, migration, and moneygram in Senegal. Africa Today, 62(3), 93-109.

Hannaford, D. (2017). Marriage without borders: Transnational spouses in neoliberal Senegal. Philadelphia: University of Pennsylvania Press.

Itzigsohn, J., \& Saucedo, S. G. (2002). Immigrant incorporation and sociocultural transnationalism. International Migration Review, 36(3), 766-798.

Kaag, M. (2008). Mouride transnational livelihoods at the margins of a European society: The case of residence Prealpino, Brescia, Italy. Journal of Ethnic \& Migration Studies, 34(2), 271-285.

Kabbanji, L. (2013). Towards a global agenda on migration and development? Evidence from Senegal. Population, Space and Place, 19(4), 415-429.

Kane, O. (2011). The homeland is the Arena: Religion, transnationalism, and the integration of Senegalese immigrants in America. Oxford: Oxford University Press.

Karlson, K. B., \& Holm, A. (2011). Decomposing primary and secondary effects: A new decomposition method. Research in Social Stratification and Mobility, 29(2), 221-237.

Kohler, U., Karlson, K. B., \& Holm, A. (2011). Comparing coefficients of nested nonlinear probability models. Stata Journal, 11(3), 420-438.

Kothari, U. (2008). Global peddlers and local networks: Migrant cosmopolitanisms. Environment and Planning D: Society and Space, 26, 500-516.

Landolt, P., Autler, L., \& Baires, S. (1999). From Hermano Lejano to Hermano Mayor: The Dialectics of Salvadoran Transnationalism. Ethnic and Racial Studies, 22(2), 290.

Levitt, P., \& Jaworsky, B. N. (2007). Transnational migration studies: Past developments and future trends. Annual Review of Sociology, 33(1), 129-156.

Massey, D. S. (2007). Categorically unequal: The American stratification system. New York: Russell Sage Foundation.

Massey, D. S., Durand, J., \& Malone, N. J. (2002). Beyond smoke and mirrors: Mexican immigration in an era of economic integration. New York: Russell Sage Foundation.

Mazzucato, V. (2008). The double engagement: Transnationalism and integration. Ghanaian migrants' lives between Ghana and The Netherlands. Journal of Ethnic and Migration Studies, 34(2), 199.

Mood, C. (2010). Logistic regression: Why we cannot do what we think we can do, and what we can do about it. European Sociological Review, 26(1), 67-82.

Mountz, A., Wright, R., Miyares, I., \& Bailey, A. J. (2002). Lives in limbo: Temporary protected status and immigrant identities. Global Networks, 2(4), 335-356.

Portes, A. (2010a). Economic sociology: A systematic inquiry. Princeton: Princeton University Press.

Portes, A., \& Rumbaut, R. (2006). Immigrant America: A portrait (3rd ed., rev.expanded, and update). Berkeley: University of California Press. 
Portes, A., \& Zhou, M. (2012). Transnationalism and development: Mexican and Chinese immigrant organizations in the United States. Population and Development Review, 38(2), 191-220.

Portes, A., Guarnizo, L. E., \& Landolt, P. (1999). The study of transnationalism: Pitfalls and promise of an emergent research field. Ethnic and Racial Studies, 22(2), 217.

Portes, A., Guarnizo, L. E., \& Haller, W. J. (2002). Transnational entrepreneurs: An alternative form of immigrant economic adaptation. American Sociological Review, 67(2), 278-298.

Rabe-Hesketh, S., \& Skrondal, A. (2008). Multilevel and longitudinal modeling using stata (2nd ed.). College Station: Stata Press.

Riccio, B. (2001). From 'ethnic group' to 'transnational community'? Senegalese migrants' ambivalent experiences and multiple trajectories. Journal of Ethnic and Migration Studies, 27, 583-599.

Riccio, B. (2008). West African transnationalisms compared: Ghanaians and Senegalese in Italy. Journal of Ethnic \& Migration Studies, 34(2), 217-234.

Rodríguez, G., \& Elo, I. (2003). Intra-class correlation in random-effects models for binary data. Stata Journal, 3(1), 32-46.

Ruhs, M., \& Anderson, B. (2010). Semi-compliance and illegality in migrant labour markets: An analysis of migrants, employers and the state in the UK. Population, Space and Place, 16(3), 195-211.

Sana, M. (2005). Buying membership in the transnational community: Migrant remittances, social status, and assimilation. Population Research and Policy Review, 24(3), 231-261.

Schiller, G., Nina, L. B., \& Blanc, C. S. (1995). From immigrant to transmigrant: Theorizing transnational migration. Anthropological Quarterly, 68(1), 48-63.

Schoumaker, B., \& Mezger, C. (2013). Sampling and computation weights in the MAFE surveys. 6. Institut national d'études démographiques.

Schoumaker, B., Flahaux, M.-L., Schans, D., Beauchemin, C., Mazzucato, V., \& Sakho, P. (2013). Changing patterns of African migration: A comparative analysis. MAFE Working Paper 18 (Vol. 18). Paris: INED.

Sciortino, G. (2004). Between phantoms and necessary evils. Some critical points in the study of irregular migrations to Western Europe. In A. Böcker, B. de Hart, \& I. Michalowski (Eds.), IMIS-beiträge: Migration and the regulation of social integration. Osnabrück: Institut für Migrationsforschung und Interkulturelle Studien (IMIS).

Smith, R. C. (2006). Mexican New York: Transnational lives of new immigrants. Berkeley: University of California Press.

Spire, A. (2005). Etrangers à la carte: L'administration de l'immigration en France (1945-1975). Paris: Grasset.

Tall, S. M. (2008a). La Migration International Sénégalaise: Des Recrutements de Main-d'oeuvre Aux Pirogues. In M.-C. Diop (Ed.), Le Sénégal Des Migrations: Mobilités, Identités Et Sociétés, Hommes et sociétés (pp. 37-67). Paris: Karthala.

Timera, M. (1997). L'immigration Africaine En France: Regards Des Autres et Repli Sur Soi: La France et Les Migrants Africains= The African immigration in France: The withdrawal of the other: France and the African migrants. Politique Africaine, 67, 41-47.

Urry, J. (2002). Mobility and proximity. Sociology, 36(2), 255-274.

Van Meeteren, M. (2012). Transnational activities and aspirations of irregular migrants in Belgium and the Netherlands. Global Networks, 12(3), 314-332.

van Nieuwenhuyze, I. (2008). Getting by in Europe's urban labour markets: Senegambian migrants' strategies for survival, Documentation and Mobility. Amsterdam: Amsterdam University Press.

Vertovec, S. (2003). Migration and other modes of transnationalism: Towards conceptual crossfertilization. International Migration Review, 37(3), 641-665.

Waldinger, R. (2008). Between 'here' and 'there': Immigrant cross-border activities and loyalties. International Migration Review, 42(1), 3-29.

Waldinger, R., \& Fitzgerald, D. (2004). Transnationalism in question. American Journal of Sociology, 109(5), 1177-1195. 
Weil, P. (2002). Towards a coherent policy of co-development. International Migration, 40(3), $41-55$.

World Bank Group. (2016). Migration and remittances factbook 2016 (3rd ed.). Washington, DC: World Bank.

World Bank Group. (2017). Annual remittances data, inflows. Washington, D.C.: World Bank.

Zolberg. (1999). Matters of state: Theorizing immigration policy. In C. Hirschman, J. DeWind, \& P. Kasinitz (Eds.), The handbook of international migration: The American experience (pp. 71-92). New York: Russell Sage Foundation.

Open Access This chapter is licensed under the terms of the Creative Commons Attribution 4.0 International License (http://creativecommons.org/licenses/by/4.0/), which permits use, sharing, adaptation, distribution and reproduction in any medium or format, as long as you give appropriate credit to the original author(s) and the source, provide a link to the Creative Commons licence and indicate if changes were made.

The images or other third party material in this chapter are included in the chapter's Creative Commons licence, unless indicated otherwise in a credit line to the material. If material is not included in the chapter's Creative Commons licence and your intended use is not permitted by statutory regulation or exceeds the permitted use, you will need to obtain permission directly from the copyright holder.

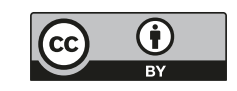




\section{Chapter 6 \\ Conclusion}

Migrants from Senegal have gained renown for their mobility, especially to European destinations. In 2010 Senegalese migrants accounted for more than $4 \%$ of migrants born in sub-Saharan Africa living in OECD countries, while Senegal accounted for less than $1.5 \%$ of the total population of sub-Saharan Africa. Senegalese migrants were the largest sub-Saharan African migrant group in Italy and Spain in 2010, accounting respectively for $23 \%$ and $27 \%$ of all sub-Saharan migrants, and the third-largest such group in France, accounting for $13 \%$ of the population born in this region. Senegalese also made up a significant share of the overall foreign-born population in these three destination countries: almost $1 \%$ in Spain, $1.3 \%$ in Italy, and 1.6\% in France. While Senegalese migrants have established a presence overseas, they have also profoundly shaped the economy and culture of Senegal. Not only does Senegal rank third in sub-Saharan Africa in the total volume of cash remittances received, but a "culture of migration" has emerged in Senegal that values the economic and social contributions of emigrants. Senegalese migrants themselves also remain connected to Senegal for their sense of social status.

While prior research has demonstrated the importance of this migrant group, scholarship has not fully grappled with the role that legal status plays in the lives of Senegalese migrants. Research on Senegalese in Italy, for example, has shown the importance of "transnational livelihoods" for their economic success and ongoing connections with Senegal, but this research has not investigated how lack of fully regular legal status may impede this strategy. Other studies have shown the importance of maintaining transnational connections for the social status of Senegalese migrants, yet only suggests the potential constraints that irregularity of legal status might place on physical mobility and other cross-border actions. The lack of sustained attention to legal status among Senegalese migrants is all the more surprising given the configurations of irregularity that Senegalese migrants have faced over time in their main destination countries. Immigration policies in France, Italy, and Spain have consistently created the legal conditions for irregularity among Senegalese migrants, as evidenced by their overrepresentation in regularization 
programs in Italy and Spain and their participation in the sans papiers movement in France in the 1990s.

This book has examined the determinants and impacts of complex forms of irregular legal status among Senegalese migrants in Europe. It elucidated how multiple contexts of reception produce pathways of irregular legal statuses among Senegalese migrants in France, Italy, and Spain and how the resulting complex pathways of irregular status shape the economic integration of Senegalese migrants into their host societies as well as their ongoing participation in the development of their homeland.

The three parts of the book have taken an articulated approach to these topics and have drawn on both legal texts and the unique Migration between Africa and Europe (MAFE) survey. The first part sketched the legal histories of the immigration policies facing Senegalese migrants in France, Italy, and Spain and the resulting configurations of irregularity that these policies created. The second part empirically examined the pathways into these different configurations of irregularity among Senegalese migrants using the MAFE data. The third part sought to understand how different configurations of irregularity constrain the economic and transnational activities of Senegalese migrants.

\subsection{Evolution of Immigration-Control Policies in France, Italy, and Spain}

Chapter 2 laid the historical foundations for this research by tracing the evolution of immigration policies and the mechanisms of external and internal control (Brochmann 1999) they define in the main European destinations of Senegalese migrants: France, Italy, and Spain. Immigration-control policies have played an important role in structuring the migration strategies and incorporation of Senegalese migrants in France, Italy, and Spain. In France, there has been an evolution from colonial-era political and personal "assimilation" of Senegalese to the French nation; to a post-independence preferential regime that put few restrictions on the ability of Senegalese to enter, reside, or work in France; to a gradual erosion of the Franco-Senegalese bilateral relationship and an alignment with the general immigration-control regime. Senegalese in France thus had de facto regular status for much of the 1960s and 1970s in that they did not need explicit authorization to enter or reside in France and were able to take advantage of common post facto regularization procedures. Irregularity became more common among Senegalese as this preferential regime crumbled, and the participation of Senegalese and other Africans in the sans papiers movement in the mid-1990s highlighted the extent to which changes in immigration-control legislation had created precarity in their legal statuses.

The evolution of immigration-control policies in Italy and Spain took a much different trajectory. Spanish and Italian apparatuses of immigration control are 
much more recent: neither had any national-level immigration policy with the normative status of legislation until the 1990s. Irregularity seems to have been a consistent component in contexts of reception in Italy and Spain, as their frequent and massive regularization programs demonstrate. Much of this irregularity seems to stem from the mismatch between restrictive immigration-control measures and structural demands for cheap, low-skilled labor (Finotelli and Sciortino 2009; González-Enríquez 2009; Reyneri 2003). Partly as a result of this mass irregularity, immigration-control policy in both countries has since developed in a restrictive fashion, marked by an overriding concern with border control along Mediterranean coastlines.

In tracing these differential evolutions, Chap. 2 underlined that the legal status that migrants possess is a relational product (Sciortino 2004): interaction between a state's policies and a migrant's strategies creates different kinds of administrative statuses. Immigration policies and their control mechanisms have thus created legal parameters that define the legal pathways that migrants navigate.

\subsection{Pathways into Irregular Legal Status}

Chapter 3 examined the pathways into irregular statuses among Senegalese migrants in Europe. Drawing on literature that argues for both multidimensional definitions of irregularity and recognizing the important role that socio-legal contexts play in setting the parameters of irregularity, the chapter hypothesized that context, measured by both destination and period, would structure both geographic and status flows into irregularity. The chapter also hypothesized that pathways of irregularity would be linked, and that forms of capital and links to host-country institutions would also be correlated with irregularity.

Retrospective life-history data from the MAFE-Senegal project was used to study the determinants of the pathways into irregularity of no-visa entry, overstaying, and befallen irregularity. Senegalese migrants going to Italy were the most likely to have entered without a visa, while overstaying was more prevalent in southern Europe than in France. These results thus showed that context plays a strong role in shaping no-visa entry and visa overstay, pathways that occur close in time to the act of crossing a border. These pathways are likely to be the most responsive to variation over time and across destination of the socio-legal parameters of legal status since most of these parameters have increasingly converged on preventing irregular entry. These findings support research that views irregularity of status as a "legal production" of immigration policies and mechanisms of control (De Genova 2002; Sciortino 2004).

These early-trajectory pathways into irregularity are also responsive to migrants' various forms of capital: migrants who have greater access to financial, human, and social capital are less likely to follow these paths into irregularity; migration-specific social capital in the form of prior no-visa entry facilitate current no-visa entry, but an increase in the number of previous trips protects against first-status irregularity. 
Migrant agency thus also structures the pathways that they take or manage to avoid, buttressing other findings in the literature that understand state structures as conditioning migrant action but not completely constraining them (Bakewell 2010; Coutin 1998; Sciortino 2004).

Changes in legal status, such as befallen irregularity, are more responsive to links to institutions in the destination country, such as the labor market, suggesting that migrants participate actively in avoiding pathways into irregularity as part of a project of integration. Unemployment is, somewhat paradoxically, related to decreased probability of loss of regular status, which suggests that the link between labor market participation and legal status depends crucially on whether or not the migrant works in the formal sector (Reyneri 2003).

In addition to findings on context and links to institutions, Chap. 3 found that previous legal status was an important predictor of all of the pathways. This supports the emerging view in research on legal status that a static binary measure of legal status is not sufficient to capture the complexity of legal status categories and transitions over migrants' life courses. This chapter thus contributes to the call for disaggregating legal status (Donato and Armenta 2011) and examining connections between different kinds of legal status.

\subsection{Legal Status, Gender, and Labor Market Incorporation}

Chapter 4 examined how immigration policy creates gendered channels of access to destination societies' labor markets. The chapter hypothesized that the effect of legal status on economic incorporation would differ for women and men: women's legal statuses are more likely to be the product of dependency-inducing family reunification policies that disincentivize work (Boyd 1989; Kofman 1999), while men would have more options for labor-market access regardless of legal status (Kogan 2006). Women's labor-market participation would thus be structured by their legal status, with those women reunifying with spouses at a destination less likely to work upon arrival than autonomous women or men (Lesselier 2008). At the same time, the chapter hypothesized that female reunifiers may also have an easier time making eventual transitions into the labor market (Kanaiaupuni 2000).

The results indicated that Senegalese women with configurations of legal status indicative of family reunification were more likely than women with other legal statuses to be economically inactive upon arrival, while there is little association between Senegalese men's legal status and their participation. This finding held across destination countries despite the differing configurations of legal status granted to reunified spouses: while mixed status among women was associated with higher inactivity in Spain and Italy, so was fully regular status in France. This is consonant with research that finds that reunified spouses tend to be less likely to be economically active (Kofman 1999). In the case of Spain and Italy these women face legal barriers to their participation as a result of waiting periods (Kofman 2004). Women in France, however, do not face such barriers, meaning that their 
legal situation is also indicative of economic dependency (Lesselier 2008). The chapter also found, however, that family reunification does not preclude labormarket participation, as many of the women with family-reunification profiles eventually transition into economic activity. This finding echoes the observation that family migration may transform into a form of labor migration (Kofman 1999). It also supports the view that women migrants have a diversity of motivations for their migration, and may often strategically participate in an "associational" move for economic reasons (Kanaiaupuni 2000). In contrast to Senegalese women, male migrants with fully irregular status (NRP_NWP) did not face any penalty in labormarket participation, employment, or the risk of transition to unemployment compared to migrants with fully regular status. There thus seems to be only a weak legal constraint of irregularity of legal status on economic activity for Senegalese migrants in Europe., This finding echoes research that demonstrates that immigrants to countries high labor-market informality and demand for low-skilled labor may reduce the immigrant "employment penalty" (Kogan 2006), but may also channel immigrants into "bad jobs" (Fullin and Reyneri 2011).

\subsection{Legal Status and Transnational Activities}

Chapter 5 considered the constraint that irregular legal status might impose on the cross-border activities of Senegalese migrants in their main contexts of reception. While the literature on transnationalism has often lauded the ability of migrants to subvert state authority via their cross-border activities, this chapter argued that state action needs to be brought back into the analysis of transnationalism. It proposed that state action works most directly as territorial confinement (Waldinger 2008): those migrants who lack secure legal status are unable to cross physical borders at their will. The chapter also hypothesized that lack of regular legal status would impede migrants' ability to cross various institutional boundaries that would block their non-mobile transnational activities (Portes and Rumbaut 2006; Van Meeteren 2012). The chapter sought to understand the link between mobile and non-mobile transnational activities by drawing on literature that argues for the importance of physical co-presence in building and sustaining affective and trusting relationships (Urry 2002) and thus hypothesized that physical visits to the homeland would facilitate non-mobile transnational activities. Finally, the chapter hypothesized an indirect constraint of irregular legal statuses on non-mobile activities operating through territorial confinement: migrants without the ability to make visits to the homeland are less likely to be able to maintain social ties that depend on occasional physical co-presence, and are thus less likely to participate in non-mobile transnational activities that depend on active social ties. The chapter used the MAFE data and its information on Senegalese migrants' transnational activities directed towards their homeland in the form of short returns, remittances, investments, and participation in hometown associations (HTAs). 
The results of Chap. 5 unambiguously supported the territorial confinement hypothesis: Senegalese migrants with fully irregular or mixed statuses were significantly less likely to make short returns to the homeland. This finding supports Waldinger's (2008) contention that nation states play an important role in structuring and constraining migrants' cross-border activities. The results of the chapter also supported the hypothesis that migrants' transnational activities can be blocked by their lack of secure legal status and the exclusion from other formal institutions that ensues. Fully irregular status operated as a direct constraint on remitting, investing, and HTA participation for Senegalese migrants. While the exact mechanism of this juridical constraint on non-mobile activities remains to be explored, the finding of structural exclusion is in line with previous findings (Portes and Rumbaut 2006; Van Meeteren 2012).

Chapter 5 also offered evidence for a positive relationship between visits to the homeland and non-mobile transnational activities. This is a relationship that the literature on transnationalism often implies (Portes and Zhou 2012; Smith 2006) but rarely directly examines. This form of mobility, along with other affective links, is thus of crucial importance in explaining these financial forms of non-mobile transnational activities. The link between physical mobility and non-mobile activities provides the theoretical lynchpin for the hypothesis of an indirect, negative effect of irregular legal statuses on non-mobile transnational activities. This indirect effect was evident for remitting and investing, meaning that their non-mobile actions were indirectly caged by the irregular status that led to their territorial confinement (Waldinger 2008). The juridical constraint was thus transmitted through the inability to circulate between destination and origin. Migrants who have irregular status thus face three kinds of legal constraints on their cross-border actions: a direct legal constraint on their physical mobility, limiting short returns to Senegal; a direct legal constraint on their formal institutional participation, limiting their remitting, investing, and HTA participation; and an indirect legal constraint on their remitting and investing through their inability to visit home and the concomitant curtailing of social ties.

Finally, the chapter offered further evidence that different transnational activities, while often taken as a monolithic object of analysis, have different determinants and do not necessarily cluster together (Waldinger 2008; Van Meeteren 2012). While remitting and investing are part of a household strategy of migration and are responsive to short visits and other affective links, HTA participation is a collective activity and, as such, seems to be less responsive to physical co-presence in Senegal and affective ties to the homeland.

These chapters have drawn on the rich information available in the MAFESenegal dataset to complement the analyses of legal status with other contextual and individual predictors of action. The results indicate that lack of secure legal status can serve as important legal constraint on the actions of migrants (Sciortino 2004) and contribute to the growing research literature on legal status as an important axis of stratification in modern societies (Massey 2007; Menjívar 2010). The results also demonstrate that legal status constrains but does not completely determine migrants' actions (Van Meeteren 2012). This is an important point of articulation with the 
body of research that considers the tension between structure and agency in migration research (Bakewell 2010; Goss and Lindquist 1995). While this book cannot attempt to offer a resolution to a tension that marks most fields of social inquiry, the results nonetheless support the view that social action may be structurally conditioned but not totally structurally determined (Bakewell 2010).

\subsection{What Is Irregularity and Why Does It Matter?}

The early pages of this book asked the question, "What is irregularity?" While the answer focused on the lexical differences between a variety of terms capturing different forms of irregularity often used interchangeably, the discussion highlighted the lack of theoretical precision often underlying sociological work focusing on migrant legal status. The first and second parts of this book took this imprecision as an opportunity to examine more deeply different configurations of legal status among Senegalese migrants, in terms of both their historical creation via immigration policies and the pathways via which Senegalese migrants enter them. The third part of the book tackled a different question: how does irregularity matter? How does it constrain the actions of Senegalese migrants? Chapters 4 and 5 thus confronted additional theoretical hurdles involving concepts of economic and transnational activities.

This section will consider the contributions that this book has made to theoretical progress in the study of irregular migration, migrant economic incorporation, and immigrant transnationalism. "Theory" here is defined as the definition and systematic linking of concepts that reflects accumulated knowledge and leads to new research in a given field of inquiry. As Portes (1997) argues, the field of migration research has both been blessed and limited by a reliance on the accumulation of empirical data and the avoidance of grand theorizing. The rich array of source material at multiple levels of analysis generated by a variety of methodologies has helped build the study of migration into a flexible and expansive enterprise, while the diversity of cases has helped the field avoid overly grandiose single and encompassing theories of migration.

At the same time, Portes (1997) warns of the risk of empirical results accumulating without a systematic theoretical guide to future research or to policy-making. Some of the lack of theoretical advancement in migration research has come from a mishandling of the fundamental building blocks of theory, such as concepts, empirical generalizations, typologies, and theoretical propositions. For Portes, a proper theory must contain interlinked and falsifiable theoretical propositions that specify relationships between concepts. Furthermore, theory must "travel"; that is, it must be able to provide insight into social realities under conditions which may differ from those that hold for the case at hand. In this way, theory can leverage the empirical richness of empirical case studies to guide the development of new insights. While this book has drawn on data on Senegalese migrants in Europe for its empirical analyses, it can also offer some modest contributions to theoretical progress 
through the refinement of some basic building blocks of theory that advance understanding of the production and consequences of migrant irregularity.

Concepts privilege certain parts of empirical reality as worthy of investigation and thus constitute the fundamental building block of theory. This book has privileged the concepts of "legal status" and "irregularity." As Chap. 3 argues, there is a considerable conceptual muddle in the study of legal status and irregularity. This muddle stems, in part, from a lack of clarity in the unit to which these concepts refer. The imprecision of the term "irregular migration," for example, arises from the lack of identification of the unit of analysis of which irregularity is a property: migrants can have irregular legal status, but entire flows or stocks of migrants are unlikely to be irregular. Furthermore, the rules of correspondence linking this concept to its empirical indicators are often unspecified, leading to a multitude of sometimes contradictory uses of the concepts. For example, "irregularity" often gets conflated with "unauthorized border crossing" when, in reality, this form of entry constitutes one many ways in which migrants can become irregular.

This book contributes to the refinement of the concepts of legal status and irregularity by proposing theoretical and empirical operationalizations that clarify both the unit to which the concepts refer and their rules of correspondence. By drawing on emerging literature on the multidimensionality of legal status, this book was able to define irregularity at the theoretical level in terms of the lack of one or more authorizations in multiple legal domains at different points in time. This is a nominal theoretical definition that was useful for this book but did not aspire to capture the "real" essence of irregularity. At the same time, it clarified the relationship between irregularity and the various legal domains of immigration-control mechanisms and the time-varying nature of different authorizations over a migrant's stay in a destination. This nominal theoretical definition led to an empirical operationalization of the different pathways into irregular status: no-visa entry, overstaying, and befallen irregularity reflect concrete combinations of different statuses in different legal domains. This approach allowed the analyses to overcome the conceptual muddle surrounding irregularity and has helped to put this concept on firmer theoretical and empirical ground.

The empirical findings demonstrated that it is crucially important to disaggregate binary measures of legal status. Relying on a dichotomy of documented vs. undocumented status would have obscured important variation in pathways into different forms of irregularity and in the impacts of irregular statuses on economic incorporation and transnational activities. These results also demonstrate that sensitivity to changes in legal status over time is crucial for modeling the determinants and consequences of different forms of legal status. Many studies do not incorporate timevarying measures of legal status and thus miss this important source of variation.

This book has also made a conceptual contribution to the field of immigrant transnationalism in its distinction between "mobile" and "non-mobile" transnational activities. The literature on immigrant transnationalism has defined its object of study as the ongoing connections between migrants living abroad and their home communities, often operationalized in the form of discrete activities that take place across national borders. While the literature has differentiated activities by 
their field of action-social, cultural, economic, or political-it has often ignored the physical and geographic specificity of such actions. Some actions labeled as transnational do not necessarily directly involve the physical movement through space, such as remittances, while others, such as homeland visits, do necessarily involve such movement. The book thus proposed a nominal theoretical definition that distinguishes these types of activity. While this nominalist definition leaves the door open to other conceptualizations, it makes an important contribution to a research field that has tended to ignore physical mobility, physical co-presence, and legal status.

A final conceptual contribution comes from Chap. 4's examination of migrant economic incorporation, which proposes a typology of configurations of legal statuses indicating different types of migrants. This typology was necessary in order to highlight not only the gendered implications of immigration policy, but also the different ways in which these gendered policies get translated into concrete configurations of work and residence authorizations. Without this typology, it would be impossible to understand that reunified migrants in France have a different set of legal rights than reunified migrants in Spain or Italy. Thus, the meaning of configurations of legal statuses varies across countries with different immigration-control regimes, and the typology proposed makes it possible to compare similar types of migrants in different legal contexts. As Portes (1997) makes clear, these kinds of typologies are important theoretical building blocks in migration research.

\subsection{Implications for Policy}

\subsubsection{The Unintended Consequences of Immigration Policy}

The results of this book point to the operation of unintended consequences of immigration policies pursued by the receiving states of France, Italy, and Spain. First introduced to sociology by Merton (1936), the idea that social action such as immigration policy can have unanticipated effects has been a cornerstone of analyses of American immigration policy (Massey et al. 2002; Portes 2000). These analyses have shown, for example, that efforts to stem undocumented migration to the U.S. by securing the southern border have not only failed to slow undocumented border crossings but also have contributed to a growing stock of undocumented migrants living in the U.S. by decreasing their probability of return (Massey et al. 2002, 2016). Similar unintended consequences are evident for Senegalese migrants in Europe: when France closed its borders to labor migration in the 1970s and stiffened the bilateral agreement regulating Senegalese migration, Senegalese responded in part by settling in France reunifying with wives and children, thus putting an end to a previously circular system (Timera 1997).

This book traced in depth the evolution of these immigration policies and sought to understand how policies that sought to limit irregular migration actually produced 
new pathways into irregular status. Quantitative analysis of these pathways revealed that irregularity was more common in destinations and periods where restrictive controls were put in place. Moreover, these analyses showed that migrants bring a variety of resources to bear in circumventing control strategies. Policies thus produced new forms of irregularity instead of limiting irregular migration.

Additional empirical results indicate how these unintended consequences of immigration policy influence the lives and actions of Senegalese migrants in the main receiving countries in Europe. Irregular legal statuses largely fail to accomplish their intended goal of preventing migrants from working. In addition, legal statuses operate more strongly on women's economic incorporation, with legal status configurations associated with family reunification increasing women's economic and administrative dependency via reduced labor-market participation. Legal status thus renders a vulnerable population more vulnerable. While results show that restrictive immigration policies do not necessarily stop migrants from entering, residing, and working irregularly in France, Italy, and Spain, Chap. 5 shows that these statuses do act as a constraint on their ongoing participation in their homeland.

Lacking regular status prevents Senegalese migrants from returning periodically to Senegal and thus also indirectly negatively affects their ability to participate in financial, non-mobile transnational activities because the lack of occasional physical co-presence causes social ties to wither. The lack of ability to circulate between destinations and the homeland effectively short-circuits the vaunted Senegalese "transnational livelihoods" (Kaag 2008; Riccio 2008). As Chap. 5 showed, restrictive immigration policy has thus transformed migrants initially focused on circulation and eventual return into irregular long-term settlers who risk exclusion and marginalization.

This marginalization is clearly not in the best interests of the destination society, the homeland, or the migrants themselves. The destination societies spend huge sums of money guarding borders in a time of severe fiscal austerity, yet they are unable to eliminate or reduce irregular migration; these draconian policies occur in the context of an aging population that actually needs migrant labor. These restrictive policies do, however, succeed in creating a marginalized and exploited population with few social rights who are yet unable or unwilling to return to the homeland prior to accomplishing their objectives.

The inability of migrants to circulate between destination and origin also has negative effects on their home communities. Portes (2009) argues that the development potential of migration depends, in part, on the composition and duration of migrant flows. Cyclical flows of manual laborers have the potential to have a positive impact on development by overcoming inefficiencies in sending countries' credit and product markets, transferring skills and resources, strengthening local productive structures, and preserving the demographic integrity of sending regions. This positive impact hinges on the existence of a vital community back home to remit to and develop, and cyclical flows assure that depopulation will not drain a community's vitality. In contrast, permanent flows of manual labor lead to the depopulation of sending areas and the weakening of productive infrastructures. As 
the sending community empties out to be reunited with permanently settled migrants, remittances and local productivity decline. The trend towards increasingly restrictive immigration policies that confine irregular migrants to the destination territory undercuts the cyclicality that Portes sees as vital to the positive developmental impact of labor migration.

\subsubsection{Co-development, Veiled Restriction, and the African "Capacity Crisis"}

The results of this book also suggest the failure of cooperative immigration policies undertaken in concert by governments of sending and receiving countries. This short-circuiting of the developmental potential of Senegalese migrants is at odds with recent evolutions in Europe to encourage and channel migrants' transnational activities for the effective development of their homelands. Such "co-development" programs (Grillo and Riccio 2004; Weil 2002) have become de rigeur in most European countries' official migration-management strategies (see Chapter 2 for descriptions of such programs in the most recent bilateral treaty between France and Senegal and as part of Spain's "Plan África"). These programs have also become a part of European countries' official bilateral cooperation with African governments, thereby implicating sending-country institutions in their efforts. There thus seems to be a contradiction between restrictive immigration-control policies that constrain economic integration and the physical and symbolic border-crossing of transnational activities and the co-development policies that leverage migrants' economic success and ongoing connections to their homelands.

At the same time, it is not at all clear that co-development policies can be separated from policies that seek to restrict migration. More importantly, as Kabbanji (2013) points out, most governmental organizations promoting co-development draw on a discourse of "managing" migration in the face of rising flows of clandestine Africans, with control of irregular migration seen by France, Italy, and Spain as a precondition for leveraging migrants' private initiatives for the productive development of their origin communities. This technical approach conceals the fact that co-development strategies have focused on controlling African migrants' transnational activities and promoting the return of unwanted migrants (Kabbanji 2013). Thus, border control and co-development go hand in hand with a two-pronged strategy of preventing migrants from entering destination countries and repatriating those that already live there, mostly those in irregular status.

Research has also questioned the impact of cooperative migration-management efforts and co-development policies. Most co-development programs involve relatively small sums, benefit a limited number of people, and have not yet been thoroughly evaluated for their effectiveness (Kabbanji 2013). Bilateral agreements to facilitate legal migration are also constrained by the extremely limited numbers involved and the constraints faced by the participating migrants; in the case of the 
bilateral labor program for Spain and Senegal, very few migrants were able to participate for more than one year because renewing permits is the responsibility of the employer (Kabbanji 2013). These programs also generally fail in their goal of attracting the voluntary return of migrants in the quest for "brain gain": quantitative research from the MAFE project demonstrates that Senegalese migrants' probability of long-term return to Senegal has declined as economic uncertainty in Senegal and legal precarity in Europe has increased (Schoumaker et al. 2013).

Part of the lack of effectiveness of cooperative and co-development programs could be due to the lack of legitimacy of sending-country governments in the eyes of migrants. The Senegalese government, while it tried to stem emigration in the 1960s through the imposition of exit visas (Kane 2011), has attempted to position itself over the last 10 years to be a more effective partner for migrant-led development. Nonetheless, Kabbanji (2013) reports that the government of Senegal, like other sending-country governments pursuing cooperative migration management, is often perceived to be facilitators of the goals of restriction and return. Senegal established the Ministère des Sénégalais de l'Extérieur (Ministry of Overseas Senegalese) in 2003 (Kabbanji 2013) with the goals of managing migration flows, guaranteeing the social and juridical protection of overseas Senegalese, and "promoting" overseas Senegalese. In reality, this ministry has drawn on discourses of the sharp uptick in illegal migration of Senegalese to Europe to step up its cooperative migrationmanagement efforts. The Senegalese government agreed to high-profile and controversial involuntary returns of illegal migrants from the Canary Islands in 2006 (Gagrielli 2008), and the Ministry of Youth has participated in "fight" against illegal migration and in the management of the oft-criticized bilateral labor-immigration agreement with Spain (Kabbanji 2013). It thus seems that the government of Senegal, despite professions to protect migrants abroad and support their investments in Senegal, has fallen prey to the logic of "migration management" preached by EU governments.

This collusion with restrictive European policies probably only adds to the preexisting lack of legitimacy of the Senegalese government in the eyes of many Senegalese, both migrants and non-migrants alike. Recent results from the Afrobarometer project show that public trust in all branches of the Senegalese government has been declining in recent years despite a high level of support for democracy (Afrobarometer 2009). This "capacity crisis" confronts many African states and is a fundamental factor in explaining their lack of development (Englebert 2002). This lack of capacity among African states arises, in part, because of an incongruence between pre- and post-colonial political structures, and results in a neo-patrimonial ruling system, the irrelevance of the rule of law, the evaporation of trust in institutions, and increased corruption (Englebert 2000). This kind of neopatrimonial system can also lead to a situation where communitarian association founded on the social capital inherent in extended families and ethnic networks can take the place of weak or absent coordinating institutions (Portes and Vickstrom 2011). While societies founded on this sort of macrosocial organization can function, the mechanical solidarity that substitutes for coordinating institutions can lead to a fragmentation of social order (Portes and Vickstrom 2011). 
This capacity crisis has a number of implications for the migration policies pursued by sending countries. Senegal is among those states that have experienced a lack of legitimacy and a capacity crises resulting from the spread of a neo-patrimonial system (Englebert 2002). Adepoju (2004) argues that this kind of lack of capacity among African states has been a fundamental driver of emigration from sub-Saharan Africa. At the same time, the social capital that fills the institutional vacuum also underlies the perpetuation of international migration (Massey 1993) and the widespread adoption of transnational household strategies of risk diversification and accumulation (Stark 1991). The overall failure of African states to acquire legitimacy and invest in human development has Africans to build their own institutions for their personal and collective goals that operate on social capital.

The findings of this book support the interpretation that social capital is one of the main determinants of migrants' continuing participation in the development of their origin communities: affective ties and the physical co-presence that nourishes them are strong predictors of migrants' remittances to and investments in Senegal. The main obstacle that they face in this endeavor is legal precarity in the destination countries, which undermines these social connections. This is the fundamental facet of the immigration policies of destination states and sending-state policies do little to change the fundamental juridical exclusion that many migrants face.

It is thus not surprising that Senegalese migrants would be wary of their state's institutional efforts to leverage migrants' development efforts, as it was the fundamental institutional failure of the state that led to and sustained the very act of migration. Coupled with the veiled restriction and involuntary return promoted by the cooperative migration-management policies of receiving states, there is ample reason to be skeptical about the prospects for a positive effect of co-managed migration on either migrants or their sending communities.

It is ultimately the migrants themselves and their home communities that bear the brunt of this incoherence. Effective immigration policy in Europe and Senegal alike would be best served by aligning their goals to support overall human development and capacity-building and creating opportunities for economic participation and circulation between destination and the homeland.

\section{References}

Adepoju, A. (2004). Trends in international migration in and from Africa. In D. S. Massey \& J. E. Taylor (Eds.), International migration: Prospects and policies in a global market, international studies in demography. Oxford: Oxford University Press.

Afrobarometer. (2009). Popular attitudes toward democracy in Senegal: A summary of afrobarometer indicators, 2002-2008.

Bakewell, O. (2010). Some reflections on structure and agency in migration theory. Journal of Ethnic and Migration Studies, 36(10), 1689-1708.

Boyd, M. (1989). Family and personal networks in international migration: Recent developments and new agendas. International Migration Review, 23(3), 638-670. 
Brochmann, G. (1999). The Mechanisms of control. In G. Brochmann \& T. Hammar (Eds.), Mechanisms of immigration control: A comparative analysis of European regulation policies (pp. 1-27). Oxford: Berg.

Coutin, S. B. (1998). From refugees to immigrants: The legalization strategies of Salvadoran immigrants and activists. International Migration Review, 32(4), 901-925.

De Genova, N. (2002). Migrant 'illegality' and deportability in everyday life. Annual Review of Anthropology, 31(1), 419-447.

Donato, K. M., \& Armenta, A. (2011). What we know about unauthorized migration. Annual Review of Sociology, 37, 529-543.

Englebert, P. (2000). Pre-colonial institutions, post-colonial states, and economic development in tropical Africa. Political Research Quarterly, 53(1), 7-36.

Englebert, P. (2002). State legitimacy and development in Africa. Boulder: Lynne Rienner Publishers.

Finotelli, C., \& Sciortino, G. (2009). The importance of being southern: The making of policies of immigration control in Italy. European Journal of Migration and Law, 11, 119.

Fullin, G., \& Reyneri, E. (2011). Low unemployment and bad jobs for new immigrants in Italy. International Migration, 49(1), 118-147.

Gagrielli, L. (2008). Flux et Contre-Flux Entre l'Espagne et Le Sénégal. L'externalisation Du Contrôle Des Dynamiques Migratoires Vers l'Afrique de l'Ouest. Revue Asylon(S) (3).

González-Enríquez, C. (2009). Spain, the cheap model: Irregularity and regularisation as immigration management policies. European Journal of Migration and Law, 11, 139.

Goss, J., \& Lindquist, B. (1995). Conceptualizing international labor migration: A structuration perspective. International Migration Review, 29(2), 317-351.

Grillo, R., \& Riccio, B. (2004). Translocal development: Italy-Senegal. Population, Space and Place, 10(2), 99-111.

Kaag, M. (2008). Mouride transnational livelihoods at the margins of a European society: The case of residence Prealpino, Brescia, Italy. Journal of Ethnic \& Migration Studies, 34(2), 271-285.

Kabbanji, L. (2013). Towards a global agenda on migration and development? Evidence from Senegal. Population, Space and Place, 19(4), 415-429.

Kanaiaupuni, S. M. (2000). Reframing the migration question: An analysis of men, women, and gender in Mexico. Social Forces, 78(4), 1311-1347.

Kane, O. (2011). The homeland is the Arena: Religion, transnationalism, and the integration of Senegalese immigrants in America. Oxford: Oxford University Press.

Kofman, E. (1999). Female 'birds of passage' a decade later: Gender and immigration in the European union. International Migration Review, 33(2), 269-299.

Kofman, E. (2004a). Family-related migration: A critial review of European studies. Journal of Ethnic and Migration Studies, 30(2), 243-262.

Kogan, I. (2006). Labor markets and economic incorporation among recent immigrants in Europe. Social Forces, 85(2), 697-721.

Lesselier, C. (2008). Politiques d'immigration en France : appréhender la dimension de genre. Les cahiers du CEDREF. Centre d'enseignement, d'études et de recherches pour les études féministes, 16, 189-208.

Massey, D. S. (1993). Theories of international migration: A review and appraisal. Population and Development Review, 19(3), 431.

Massey, D. S. (2007). Categorically unequal: The American stratification system. New York: Russell Sage Foundation.

Massey, D. S., Durand, J., \& Malone, N. J. (2002). Beyond smoke and mirrors: Mexican immigration in an era of economic integration. New York: Russell Sage Foundation.

Massey, D. S., Durand, J., \& Pren, K. A. (2016). Why border enforcement backfired. American Journal of Sociology, 121(5), 1557-1600.

Menjívar, C. (2010). Immigrants, immigration, and sociology: Reflecting on the state of the discipline. Sociological Inquiry, 80(1), 3-27. 
Merton, R. K. (1936). The unanticipated consequences of purposive social action. American Sociological Review, 1(6), 894-904.

Portes, A. (1997). Immigration theory for a new century: Some problems and opportunities. International Migration Review, 31(4), 799-825.

Portes, A. (2000). The hidden abode: Sociology as analysis of the unexpected: 1999 presidential address. American Sociological Review, 65(1), 1-18.

Portes, A. (2009). Migration and development: Reconciling opposite views. Ethnic and Racial Studies, 32(1), 5-22.

Portes, A., \& Rumbaut, R. (2006). Immigrant America: A portrait (3rd ed., rev.expanded, and update). Berkeley: University of California Press.

Portes, A., \& Vickstrom, E. (2011). Diversity, social capital, and cohesion. Annual Review of Sociology, 37(1), 461-479.

Portes, A., \& Zhou, M. (2012). Transnationalism and development: Mexican and Chinese immigrant organizations in the United States. Population and Development Review, 38(2), 191-220.

Reyneri, E. (2003). Immigration and the underground economy in new receiving south European countries: Manifold negative effects, manifold deep-rooted causes. International Review of Sociology, 13(1), 117-143.

Riccio, B. (2008). West African transnationalisms compared: Ghanaians and Senegalese in Italy. Journal of Ethnic \& Migration Studies, 34(2), 217-234.

Schoumaker, B., Flahaux, M.-L., Schans, D., Beauchemin, C., Mazzucato, V., \& Sakho, P. (2013). Changing patterns of African migration: A comparative analysis. MAFE Working Paper 18 (Vol. 18). Paris: INED.

Sciortino, G. (2004). Between phantoms and necessary evils. Some critical points in the study of irregular migrations to Western Europe. In A. Böcker, B. de Hart, \& I. Michalowski (Eds.), IMIS-beiträge: Migration and the regulation of social integration. Osnabrück: Institut für Migrationsforschung und Interkulturelle Studien (IMIS).

Smith, R. C. (2006). Mexican New York: Transnational lives of new immigrants. Berkeley: University of California Press.

Stark, O. (1991). The migration of labor. Cambridge, MA: B. Blackwell.

Timera, M. (1997). L'immigration Africaine En France: Regards Des Autres et Repli Sur Soi: La France et Les Migrants Africains= The African immigration in France: The withdrawal of the other: France and the African migrants. Politique Africaine, 67, 41-47.

Urry, J. (2002). Mobility and proximity. Sociology, 36(2), 255-274.

Van Meeteren, M. (2012). Transnational activities and aspirations of irregular migrants in Belgium and the Netherlands. Global Networks, 12(3), 314-332.

Waldinger, R. (2008). Between 'here' and 'there': Immigrant cross-border activities and loyalties. International Migration Review, 42(1), 3-29.

Weil, P. (2002). Towards a coherent policy of co-development. International Migration, 40(3), $41-55$.

Open Access This chapter is licensed under the terms of the Creative Commons Attribution 4.0 International License (http://creativecommons.org/licenses/by/4.0/), which permits use, sharing, adaptation, distribution and reproduction in any medium or format, as long as you give appropriate credit to the original author(s) and the source, provide a link to the Creative Commons licence and indicate if changes were made.

The images or other third party material in this chapter are included in the chapter's Creative Commons licence, unless indicated otherwise in a credit line to the material. If material is not included in the chapter's Creative Commons licence and your intended use is not permitted by statutory regulation or exceeds the permitted use, you will need to obtain permission directly from the copyright holder.

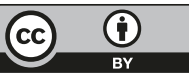




\section{Correction to: Pathways and Consequences of Legal Irregularity}

\section{Correction to: \\ E. R. Vickstrom, Pathways and Consequences of Legal Irregularity, IMISCOE Research Series, https://doi.org/10.1007/978-3-030-12088-7}

This book was inadvertently published without the inclusion of an Acknowledgement. It has now been updated.

In addition to the above, Chapters 3,4 and 5 were published without the following notices.

Portions of Chapter 3 were previously published as: Vickstrom, E. (2014). Pathways into irregular status among Senegalese migrants in Europe. International Migration Review, 48(4), 1062-1099. https://doi.org/10.1111/imre.12154.

Portions of Chapter 4 were previously published as: Vickstrom, E. R., \& GonzálezFerrer, A. (2016). Legal status, gender, and labor market participation of Senegalese migrants in France, Italy, and Spain. The Annals of the American Academy of Political and Social Science, 666(1), 164-202. https://doi.org/10.1177/ 0002716216643555.

Portions of Chapter 5 were previously published as: Vickstrom, E. R., \& Beauchemin, C. (2016). Irregular status, territorial confinement, and blocked transnationalism: Legal constraints on circulation and remittances of Senegalese migrants in France, Italy, and Spain. Comparative Migration Studies, 4(1), 1-29. https://doi.org/10.1186/ s40878-016-0037-8.

The updated version of these chapters can be found at https://doi.org/10.1007/978-3-030-12088-7

https://doi.org/10.1007/978-3-030-12088-7_3

https://doi.org/10.1007/978-3-030-12088-7_4

https://doi.org/10.1007/978-3-030-12088-7_5

(C) The Author(s) 2019 